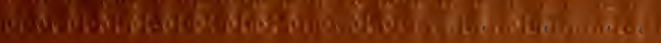


Blair. 153. 




\section{HOIRA COTICA}

$B 2^{\circ}$

\section{THA REV". JOHY LIGHIFO OT.}

$$
\text { VOL. I. }
$$

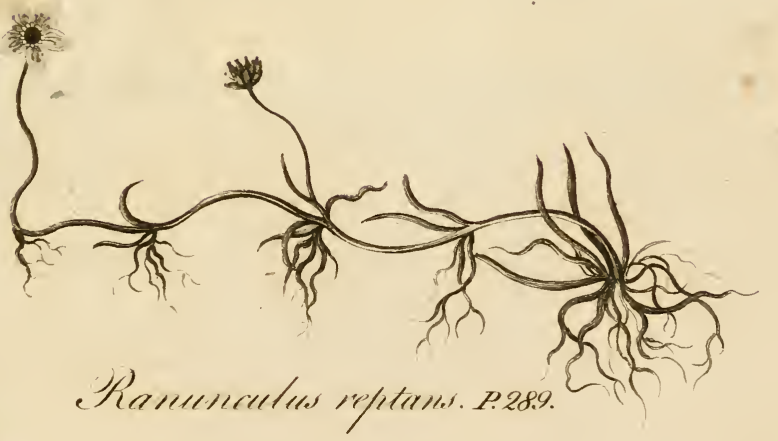

L O N J) O N.

M1 CCIXXVII.

eriffth dN. 



\section{FLORA SCOTICA:}

O R, A

\section{SYSTEMATIC ARRANGEMENT,}

I N T H E

LIN N 庄 A N METHOD;

OF THE

NA T I V E P L A N T S

D $\mathrm{F}$

SCOTLAND AND THE HEBRIDES.

By JOHN LIGHTFOOT, A. M.

De dor of Gstbam in Nottingkambire, and Chaplain to the Ducbess

Dowager of PORTLAND.

Where does the Wiftom and the Power divine,

In a more bright and fweet reflection thine ?

Where do we finer ftrokes and colours fee

Of the Creator's real poetry,

Than when we with attention look

N pon the third day's volume of the book?

If we could open and intend our eye,

We all like Mofes thould efpy,

Ey'n in a buth the radiant Deity:

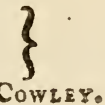

\section{I. $O$ N D}

PRINTED FOR B. WHITE,

AT HORACE'S HEAD, IN FEEET.STREET, 
Alus batker 
TO HER GRACE

THE MOST NOBLE

\section{MARGARET CAVENDISHE}

DUCHESS DOWAGER OF

$\mathrm{P} O \mathrm{R} T \mathrm{~L} A \mathrm{~N} \mathrm{D}$,

THAT GREAT AND INTELLIGENT ADMIRER

AND PATRONESS

OF NATURAL HISTORY IN GENERAL,

THE FOLLOWING FLORA,

AS AN HUMBLE EXPRESSTION OF GRATITUDE

FOR THE MANY UNSOLICITED FAVORS

HER GRACE HAS THOUGHT FIT TO CONFER

UPON HIM)

IS WITH ALL SUBMISSION INSCRIB'D,

BY HER GRACE's

MOST DUTIFUL CHAPLAIN,

AND MOST RESPECTFUL

5

AND OBEDIENT HUMBLE SERVANT, 



\section{[Y I}

\section{$P$ R E F A C E。}

THE following Work, fuch as it is, owes its appearance to Thomas Pennant, Efquire.

This gentleman, in his fecond tour and voyage to the Hebrides, in the fummer of the year 1772 , kindly invited me to partake of his company, and did every thing in his power to promote and facilitate my journey: a journey I was defirous to undertake, not only as it promifed much variety of amufement and inftruction, but as it flattered $m e$ in a particular manner with a fair opportunity of gratifying a favorite affection I had long conceived for the fcience. 
fcience of Botany, while it afforded the enchanting profpect of examining a country, whofe vegetable productions had been attended to by very few.

Mr. Pennant, who was well acquainted with the ruling pafion of his companion, firft thought fit to encourage it, by fuggefting the compilation of a FLORA ScoTICA, and promifing afterwards to uher it into the world. This promife he hath performed at his fole expence, in the moft friendly and difinterefted manner. How far the public will be obliged to him for this encouragement is a matter of fome doubt; but under it's engaging influence I could not refufe to undertake the work, and execute it to the beft of my power, both in juftice to him who was pleas'd to think me equal to the performance, and for the credit of minfelf.

Returning therefore mon grateful acknowledgments to Mr. Pennant, for the pleafures I received both in my journey and company witis him, I muft now proceed 


\section{$\begin{array}{lllllll}P & R & E & F & A & C & E .\end{array}$}

to lay before the reader a fhort plan of the work itfelf, and of the various aids I received in the execution of it.

The firft part of the book is a Nketch of Caledonian Zoology, compos'd by Mr. Pennant, and prefix'd for the benefit of thore naturalifts who wifh to be acquainted with the animals of North Britain.

This is fucceeded by the FLORA Scoti$\mathrm{CA}$, or a fyftematic arrangement of the indigenous plants of Scotland and its iflands.

This arrangement is entirely after the fexual or Linnaan method, not only as being the prefent moft approved and farhionable, but the moft ingenious and convenient, and, confequently, the moft eligible fyftem hitherto invented.

It is well known to confift of twenty-four claffes or primary divifions; at the beginning of each of which I have enumerated the feveral orders and genera contained under it, together with the Mort characters which diftinguinh each genus, after the manner of Linnaus, in the I $3^{\text {th }}$ edition of his Syftema Natura. This hort fcheme enables the

$$
\text { 2 } 4
$$

learner 
learner not only to behold at one view the various genera comprehended under each class, but alfo to diftinguilh readily their differences, and to difcover fome few fpecies of plants, which would feem to the Tyro improperly clafs'd, and might otherwife baffle his refearches in invertigating their names. Thefe irregular fpecies are therefore, to facilitate his enquiries, printed in italics, and placed at the foot of the order to which they might feem to belong.

Again, at the head of every genus its generic characters are exprefs'd more fully, in conformity to the method of the forementioned $S$ wedifh naturalift, with references to his Genera Plantarum, where thofe characters are defcribed at large.

Under each genus are arranged the feveral Species, with their trivial names and fpecific differences, all taken from the fame author, unlefs where new fpecies required new names to be given them.

Then follow references to thofe authors who have exhibited the beft figures of the feveral fpecies. The books referred to are often 
often indeed voluminous and expenfive, but they are fuch as will yield much pleafure and fatisfaction to the learner.

Next fucceeds the common Englifh name of each fpecies, and afterwards the Scotch and Gaulic or Erfe names, fo far as they are generally known and received by the inhabitants.

To thefe are fubjoin'd each plant's particular place of growth or native foil.

To which is added its duration, exprefs'd by the following figns, viz. $\odot$ which denotes the plant to be annual, of biennial, I perennial, and 5 a tree or forub. Afterwards the time of flowering, fignified by the following numbers, viz. I. II. III. \&tc. correfponding to the months of Fanuary, February, March, \&c,

Then follows a Thort defcription of each plant, or fome few diftinguifhing characters of it, fuch as were thought neceffary either to point out the difference of fpecies moft nearly allied, or to affift the learner in afcertaining thofe plants which are generally leaft known, or but ill-defcribed by authors: 
fuch efpecially are thofe of the Cryptogamia clafs, which coft more time and attention than all the other twenty-three claffes together.

Laft of all are fubjoined the various ufes of each plant, whether ceconomical, medical, or fuperfitious. Their ceconomical and medical ufes are extracted from authors of the firft credit; for the moft part either from Linnaus's Materia Medica, or Haller's Hiferia firpium Helvetia. For their Juperfitious ufes I am chiefly indebted to my oftenmentioned friend Mr. Stuart, a native of the Higblands, and perfectlyacquainted with the cuftoms of his countrymen.

In the courfe of this work, I have purpofely avoided the addition of all Jynonyms, not merely to prevent fwelling the book, but becaufe they have been fo often repeated by other authors, and feem to be at the fame time of little ufe to the learner. I therefore wholly omitted them, to make way for defcriptions, which I flatter myfelf will prove of more fervice. 


\section{$\begin{array}{lllllll}P & R & E & F & A & C & E\end{array}$}

Should I be ank'd, why, contrary to the prefent fafhion in works of this kind, I chofe to write the defcriptions and ufes of the plants in Englifs rather than Latin? I anfwer, to comply with the requeft of my beft friends. Neither do I think it any objection to the book, as it was written purely for the ufe of my countrymen, who will underftand it never the worfe for being in their own tongue.

With the theory and tecbnical terms of the fexual fyftem, and the manner how to in. vertigate an unknown plant, the reader is fuppofed to be acquainted before he takes the Flora Scotica in hand. If he hould be totally ignorant of the elements of Botany, and yet be defirous of knowing the names and ufes of any native plants which may fall in his way, I would beg leave firft to refer him either to the Pbilofopbia Botanica of Linnaes, for a Latin inftruction in the firft principles of the fcience, or to Lee's Introduction to Botany, or Rofe's Elements of Botany for an Englifh one; after which I flatter myfelf he will have little dificulty, with the help of the Flora Scotica, 
to afcertain almoft any vegetable of Caledsnian birth.

It may be thought perhaps a little arro. gant, that I hould attempt a fyftematic arrangement of the plants of a large country, without having fpent more than one fummer in it; and indeed the imputation would be juft, if I had not received the greateft affiftance therein from able and ingenious botanifts, who have refided in that country their whole lives: gentlemen, who have not only permitted me to examine their va. luable collections, but have freely communicated to me the obfervations of many years.

Among thefe I have the pleafure firf to mention with gratitude the name of Dr. Hope, the prefent celebrated profeffor of botany at Edinburgh, who not only favoured me with the fight of his copious Herbarium, but permitted me the ufe of his notes and obfervations, the refult of a long enquiry.

To the Rev. Mr. Stuart jun. late of Killin in Breadallane, now of Lufs, in the county of Dumbarton, I am indebted for

every 


\section{$P \quad R \quad E \quad F \quad A \quad C \quad E$.}

every afinfance that ingenuity and friendohip could yield. This young gentleman, a mort accurate obferver of Nature's works, and critically vers'd in the Erfe language, and the manners and cultoms of his country, I had the good-fortune to Thare as a companion and fellow-traveller through the Highlands and Hebrides; and to him I am obliged for a great portion of the Higbland botany, for many of the medical and ceconomicals-and all the fuperfitious ufes of plants which are interfperfed in this work, and to him I orve the fupply of their Erfe or Gaulic names.

To the Rev. Dr. Burgefs of Kirkmichael, in Dumfriesflire, I am eminently indebted for the botany of the Lorclands. Unfolicited and without referve, he was ready to impart all the botanical difcoveries he had made during the courfe of many years. To him I am likewife obliged for the provincia! names of plants, or thofe made ufe of by the common people of the country.

To thefe afiftances from gentlemen conftantly refident in Scotland, I mun add the friendly aids I have received from thofe who, 
like myfelf, have made only tranfient vifits in it.

Dr. Parfons, the prefent ingenious pro= feffor of anatomy at Oxford, during his medical ftudies at Edinburgh, as a neceffary concomitant to the knowledge of phyfic, made botany one of his principal purfuits, and greatly excelled in it. He was indefatigable in his enquiries into the fcience, and in collecting the objects of it; and with much gratitude I remember the liberty he gave me to reap the fruits of his labours, by permitting me to examine his Herbarium, and extract from his notes.

Mr. Yalden, a late ftudent in phyfic at Edinburgh, and a mort fagacious and unwearied naturalift, loft no opportunity during his continuance in that univerfity, of cultivating his knowledge in botany. He made a copious collection of the vegetable productions of Scotland, with many curious obfervations on them, and in the moft liberal and friendly manner fubmitted the whole to my infpection and ufe. 


\section{$\begin{array}{lllllll}P & R & E & F & A & C & E\end{array}$}

To the number of thofe friends who have contributed their affiftances towards the prefent work, I am happy to add the refpectable and celebrated names of $\mathcal{F}$ ofeph Banks Efq; and Dr. Solander, the two great philorophical luminaries of this nation; gentlemen who were ever ready to elucidate a difficult fubject, and who never fail'd to difpel the obfcurity which furrounded any dubious plant.

Nor will gratitude allow me to forget the obligations I owe to the friendly indulgence of Dr. Sibtborpe, Profeffor of Botany at Oxford, who with great freedom and kindnefs permitted me to examine Dr. Dillenius's celebrated collection of moffes now in his curtody, and thereby enabled me to folve many doubts and difficulties among the numerous ipecies of that minute tribe of vegetables.

Having now exhibited, as I propored, a Mort plan of the following work, and enumerated the various aids I received in the execution of it, it may not be amifs briefly to acquaint the reader, what were my own preparative qualifacations for the undertaking 
it. I would win therefore to let him know, that the entcrtaining fcience of Botany had been the conftant arnufement of my rides and walks for upwards of fixteen years; previous 10 my tour in Scotland; that in this tour I travelled either by land or fea from the fouth of Annandale to the borders of Sutberland, vifited mort of the Hebrides, except the LongIflank, traverted the kingdom from Argyleflire to the county of Mearns, that is, from the weftern to the eaftern hore, and afterwards return'd to Englaid by way of Edinburgh and Kelfo; that in all this tract, which took up the daily exercife of a whole fummer, I had a conftant eye to the following work, embraced every opportunity of fealing the higheft mountains, climbing the moft rugged rocks, penetrating the thickeft woods, treading the fallacious bogs, winding upon the fhores of feas and lakes, in Mort, of examining every variety of land or water, which promifed to produce a variety of vegetables.

This is mentioned only to acquaint the reader what degree of perfection he may expe\&t 
$P \quad R \quad E \quad F \quad A \quad C \quad E$.

expect from the following Flora, for I prefume not to affert that it contains every indigenous plant of the country whofe vegetables it recounts; it is fufficient that it comprehends by far the greateft part, which is as much as the Flora of any country can pretend to. The number of plants it comprifes is not very far hort of thirteen hundred, which will furely be allowed a competent foundation for an uiluertaking of this fort. Doubtlefs there are many behind undifcovered. Thefe may ferve as an incitement to others to make new refearches, and fo by degrees complete the work I have inere begun: and if at any time fuch refearches fhould be attended with difcoveries, and thofe who make them will take the trouble to communicate them to the author, fuch communications fhall at all times be gratefully acknowledged.

Should the following performance happen to excite any to the ftudy of the vegetable creation, it may pofibly become the fource of much health and pleafure, by the exercife it neceffarily promotes to the body, and 
the complacency it always begets in the mind : but tho ld it prove the happy inftrument of diverting any from foolinh and unmanly purfuits to the rational fudy of God's works, and the contemplation of his fublime attributes, manifefted therein, which is the natural tendency of fuch a ftudy, my time and labour have not been employed. in vain.

Uxbridge,
July $24,177 \%^{\circ}$ 


\section{R E F E R N C E S explained.}

AzT. Paris.

EMOIRES de l'Academie Royale $1 \sqrt{1}$ des Sciences. Paris. 4to.

Arduin. Spec. Petri Arduini Obfervationum Botanicarum Specimen I. Patav. anno 1759. 4to. \& II. ibid. anno 1764 . 4 to.

Arduin. Mem. Ejufdem Memorie Differtationi \& Defcrizzioni anno 1766. 4to. Patav.

Amman. St.rar.Ruth. Joannis Ammani Stirpium rarioru m in Imperio Ruthenico, \&c. Petrop. I739. 4to. Amman. com.Petrop. Ejufdem Lapatbum orientale pulchrum Comment. Petrob. T. xiII.

Barrel. icon.

Jacobi Barrelieri Icones Plantarum per Galliam, Hifpaniam et Italiam obfervatarum. Paris. 1714. Fol.

Bafter. opufa Jobi Bafteri opufcủla fubfeciva, \&c. tom. I. \& tom. 2. Harlem. 1762. 1,65 .

Blacks. Jpec. bot. J. Blackftone Specimen Botanicum. Lond. 1746. $12^{\circ}$.

Baubin. Prod. Cafpari Baubini Prodromus et Pinax. Ваfil. $1671.4^{\circ}$.

Baubin. bif. Joannis Baubini Hiftoria Plantarum univerfalis, Ebrodun. 1650. fol. 
Blakwell's Herb. Elizabeth Blakwell's curious Herbal. Lond. r 739 . fol. 2 vol. et auctius meliufq. cura Cb. Fac. Trero. Norimberg. 174I. feqq. fol. 5 vol.

Buxb. Hallenf. Joannis Chrifiani Buxbaum Enumeratio plantarum in Agro Hallenfi, Halæ Magdeb. $172 \mathrm{I}$. 8vo.

Buxb. Cent.

Ejufdem plantarum minus cognitarum Centuriæ quinque. I. et II. I72 I. III. I 729 . IV. 1733. V. 1740. Petrop. 4to.

Boccon. Muf.

Pauli Boccone Mufrum plantarum rariorum. Venet. 1697.4 to.

Boccon. pl. rar. Pauli Boccone plantarum rariorum Siciiize icones et defcriptiones. Oxon. 1674. 4 to. Column ecpbraf. Fabii Columne Ecphrafis I. et II. minus cognitarum rariorumque ftirpium. Romæ. 1616. 4to.

Crantz. Greenl. David Crantz's Hitory of Greenland. Tranflated from the German. 2 vol. 8vo. London. I 767 .

Dalecb. bift. Jacobi Dalecbampii Hirtoria generalis Plantarum. Lugd. 1584. fol.

Dillen. Eltbam. Joannis Jacobi Dillenii Hortus Elthamenfis, feu Delineationes plantarum rariorum. Lond. 732 . fol.

Dillen. mufc. Joannis Jacobi Dillenii Hiftoria mufcorum. Oxon. 1741. 4to.

Dubamel. arb. Du Hamel Traitè des arbres et des arbuftes. Paris. 1755.2 vol. 4 to. 
Flor. Suec.

Caroli Linnei Flora Suecica. Stockholmiæ: 1755. 8 vo.

Ger. emac.

Joannis Gerardi Hiftoria Plantarum a Thoma Fobnfon emaculata. London. 1633 . et $16{ }_{3} 6$. fol.

Gerard. Gallopr. Ludovici Gercrdi Flora Galloprovincialis. Paris. 176r. 8vo.

Gefner. icon. an. Conradi Gefneri Opera botanica iconibus æneis. Nuremberg. 1752 . fol.

Gledit. fung. Joan. Gottlieb Gleditcbii Methodus Fungo: rum. Berol. 1753. Svo.

Gmel. Sibir. Joannis Georg. Gmelini Flora Sibirica. I: II. vol. Petrop. 1750. III. I768. IV. 1769. 4 to.

Gmel. Fucor. Ejjufdem Hiftoria Fucorum. Petrop. I768. 450.

Gunner.Fl.Norveg. J. Ernef. Gumeri. Flora Norvegica. Nidros. 1766 . fol.

Haller. firp. Helv. Alberti Haller Hiftoria ftirpium indigenarum Helvetix. Bernæ. 1768. 2 vol. fol. Haller. opufc. Alberti Haller Opufcula Botaniça recula et aucta. Gottingæ. I749. 8 vo.

Hort. Aicbjfet. f. Eyflet. Bafilii Befleri Horius Aichftettenfis f. Eyftettenfis, Noremb. I6 ${ }_{1} 3$. fol. et I $6_{40}$. fol.

Hudf. Fl. Angl. Gulielmi Hudjons Flora Angiica. Londini. I762. 8vo.

Herm. Paradif. Pauli Hermanni Paradifus Batavus. Lugd. I698. 4to.

b 3

façuin. 


\section{REFERENCES EXPLAINED.}

facquin. obs.

Lin. Gen. pl.

Lin. Sp. pl.

Lin. Flor. Suec.

Lin. Fl. Lap.

Lin: Jyt. nat.

Lin. Mantiss.
Nicolai Jofeph facquin Obfervationes Ba= tanicæ. P. I. Vienn. 1764 . fol, et P. II. I767. fol.

Caroli Linnxi Genera Plantarum. Holmix. I764. 8 vo. edit. 6ta.

Ejufdem Species plentarum. Holmix. 1762 : edit. fecunda. $\delta$ vo. 2 vol.

Ejufdem Flcra Suecica. Stockholmix.1755. 8 vo.

Ejuf́em Flora Lapponica. Amftelodami. 1737. 8 vo.

Ejufdem Syftema Naturæ. Holmiæ. I 766 . et 1777 . II. tom. 8 vo. primus in 2 partibus-Et Syftema vegetabilium. Gottingæ. 1774. 1. vol. 8vo. edit. $13^{3}$.

Ejufdem Mantifa Plantarum, ad finem Syftematis Nature prius dicti in tom. 2do. Holmix. $1 ; 67$.

Et Altera Mantifa Plantarum. Holmia. $1771.8 \mathrm{vo}$.

Las. Prufs. Joannis Laeselii Flora Pruficica. Regimont. 17034 to.

Magnol. bort. Monfpel. Petri Magnol Hortus regius Monfpelienfis. Monfpelii. 1697. 8 vo.

Marten. Spitferg. Frederici Martens Itinerarium Spitbergenfe et Groenlandicum. Hamb. 1675 . 4to. germanice. Amfteiodam. 1685. 4to. Belgice. Anglice à Rajo. 
Mentz. pug.

Chriftiani Mentzelii Index Plantarum et Pugillus. Berolin. 1696. fol.

Moris. bift. Ox. Roberti Morifoni et Jacobi Bobarti Hiftoria Plantarum Oxonienfis. III vol. fol. Oxon. 1680.

Oeder. Fl. Dan. Georgii Chriftiani Oeder Flora Danica. P.I. Hafnia. 1761. fol. et reliqui tom: ad IX. Parkinjon. Joannis Parkinfoni Theatrum Botanicum. Lond. 1640. fol.-Ejufdem Paradifus terreftris. Lond. 1629. fol.

Pluk. alm. et phyt. Leonardi Plukenetii Almageftum Botanicum et Phytographia. Lond. 4to. diverio ampore edita.

Pennant's Tour. A Tour in Scotland and Voyage to the Hebrides, by Tho. Pennant, Efq. 2 vol. 4to. Chefter. 1774. and $2 \mathrm{~d}$ part. London. $1776.4^{\text {to. }}$

Raii Syn.

Joannis Raii Synopfis Methodica Stirpium Britannicarum. edit. III. Lond. 1724. 8vo. R. Hift. Ejufdem Hiftoria Plantarum. 3. Lond. 1686. et 1704. fol.

Rivin. irr. mon. ic. Augufti Quirini Rivini ordines Plantarum flore irregulari monopetalo, tetrapetalo, et pentapetalo. Lipfia. I6g I et 1699. fol. Roef. infecz. Augufti Joannis Roefel Hitoria Intectarum cum aliquot figuris Plantarum. Norimberg. 4 io. 1749.4 tom.

Scbaff. Fung, Jac. Chriltiani Schceffer. Hiftoria Fungorum b 4

circa 
circa Ratißonam nafcentium. Ratißbon. $176_{2}$ et $176_{3}$, \&c. Centuriæ Ill. 4to. Scbeucbz. Agrof. Joannis Jacobi Scbeucbzeri Agroftographia. Tigurii. I719. 4to.

Scbuchz. Itin. Alp. Ejufuen Itinera alpina tria. Lond. 1708. 4to. et ejufdem Itinera Alpina IX. 1723. 4to. 2 vol.

Scbmidel. icon. Cafinir Chriftopheri Scbmidel icones plantarum et analyfes æri incifæ. Norimberg, 1748. fol. tabulis 19 .

Ejufdem Buxbaumia. 1758.

Ejufdem Blafia. 1759 .

Fjufdem Fungermannia. $176 \mathrm{I}$.

Scbreber. gram. Joannis Chriftiani Scbreber Defcriptio Graminum. Lipfig. 1769 . fol.

Scopol. Fl. Carniol. Joannis Antonii Scopoli Flora Carniolica, edit. $2^{\text {ca. }}$. Vindobon. 1772.8 vo. 2 tom.

Seguier. Veron. J. Franc. Seguier Plantæ Veronenfes. Veronæ. 1745. 8vo. 2 vol.

Ejufdem Supplementum. ibideın. I 754.8 vo.

Sibbald. Scot.it. Roberti Sibbaldi Scotia illuftrata. Edinb, 1684. fol.

Sterb. Fung. Francifi van Sterbeeck Theatrum Fungorum. Belgice. Antwerp. 1675. 4to.

Stilling. Trad. Berjamin Stillingfleet's mifcellaneous Tracts. Lond. 1762 . 8vo.

Tabcrnamont. ic. Jacobi Theodori Tabernamontani Icones Mlantarum. Franc. 1690. 4to.

Tbal. 
Thal. Harc. Joannis Thalii Harcynia Sylva. 1588. 4to. Francfort.

Tournef. In. R. H. Jofephi Pitton Tournefort Infuitutiones Rei Herbariæ. Paris. I 700. 4to.

Vaill. Paris. Sebaftiani Vaillant Botanicon Parifienfe. Wis. Crypt. Frederici Gulielmi Wis Plantæ Cryptogamicæ Floræ Gottingenfis, Gottingæ. I $77^{\circ}$ $8 \mathrm{vo}^{\circ}$ 


\section{ERRORS of the PRESS,}

\section{Which the Reader is defired to correct with his pen.}

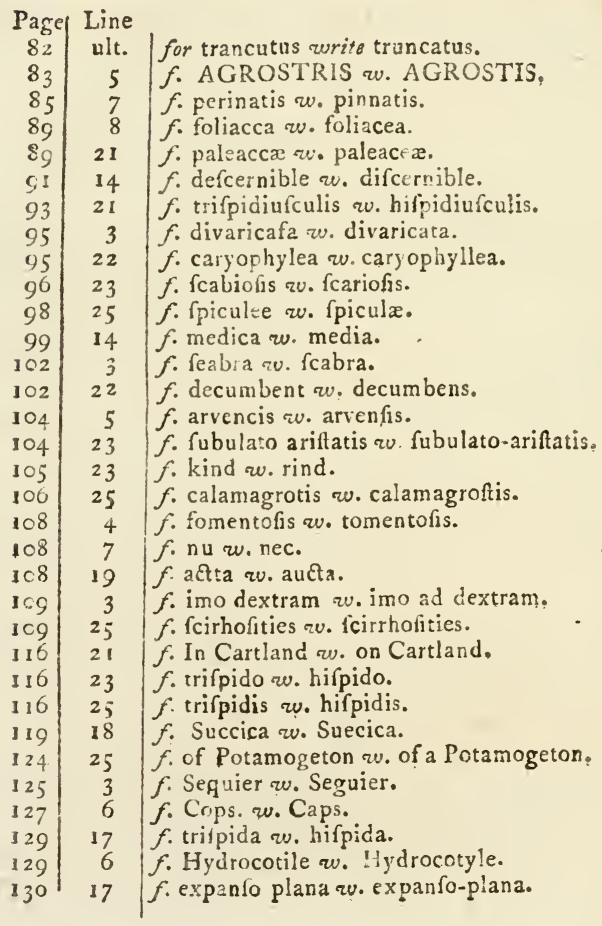




\begin{tabular}{|c|c|c|}
\hline Pag & Line & \\
\hline $13^{2}$ & 7 & f. Morit w. Moris. \\
\hline 132 & 24 & f. Moritt. w. Moris. \\
\hline 134 & 4 & $f$. Holt. w. Hort. \\
\hline 34 & 6 & erafe Tour Scotl. 1772. qto, tab. \\
\hline 134 & 9 & $\begin{array}{l}\text { for affording vegetation } w \text {. afrording nourift } \\
\text { men: for vegetation. }\end{array}$ \\
\hline 137 & 3 & $f_{\text {: }}$ queens w. queen. \\
\hline 140 & 4 & $\begin{array}{l}\text { eraje the comma after the word Benmor, a } \\
\text { alfo after Ben-Croachan. }\end{array}$ \\
\hline 140 & 25 & $f$. protrato w. proftrato. \\
\hline 44 & 15 & a limbs w. and ufe of his limbs. \\
\hline 151 & 3 & e without dent w. have $n$ \\
\hline $15 \mathrm{I}$ & 19 & afting w. making; and Alkali in Italic \\
\hline 152 & 25 & f. Corolli zu. Corollis. \\
\hline 152 & ult. & f. Quadrified w. Quadrifid. \\
\hline 53 & 12 & 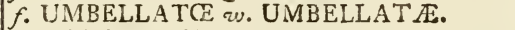 \\
\hline 55 & 6 & w. hifpidus. \\
\hline $5^{8}$ & 7 & 9quales. \\
\hline 158 & 22 & LEUM z. HER ACLEUM. \\
\hline $5^{8}$ & 25 & rd fuperioris add a full period. \\
\hline 59 & 29 & $\begin{array}{l}\text { after Tour in Scotl. } 1772 \text {. qto. edit. add } \mathrm{Pa} \\
\text { II. pag. } 20,5 \cdot \text { tab. XXIV. }\end{array}$ \\
\hline 161 & 2 & w. to be a pair. \\
\hline 161 & 5 & rd benè ad \\
\hline 162 & 3 & $f$. they refemble w. the partial ones refemble \\
\hline 162 & 6 & after Moris. hitt. S. add 9 : \\
\hline 164 & 8 & cicuta. \\
\hline 164 & ult: & after cicuta erafe the ftop. \\
\hline 165 & 23 & laciniz. \\
\hline 167 & 2 & evi w. lxvi. \\
\hline i 67 & 2 I & orift. zu. Moris. \\
\hline 371 & 17 & arboreo. \\
\hline 174 & 26 & $f$. \\
\hline 180 & 6 & w. fubulato filiformia join'd by a hyphen. \\
\hline I 81 & 23 & w. a comma after the worc \\
\hline 184 & 28 & $f$. dextrom $w$. dextram. \\
\hline 184 & 28 & $f$ ad p. 12. w. p. 12, ad. \\
\hline 185 & 22 & heuck w. Scheuch. \\
\hline 188 & 21 & $f$. gramiferis $w$. graniferis. \\
\hline 189 & 18 & $f$. and wafte places $w$. and in wafte places. \\
\hline 191 & 27 & $\begin{array}{l}\text { erafe the hyphen between the figure } 3 \text { and th } \\
\text { word calyciformia. }\end{array}$ \\
\hline & 14 & e the hyphen after the figure 3 . \\
\hline
\end{tabular}




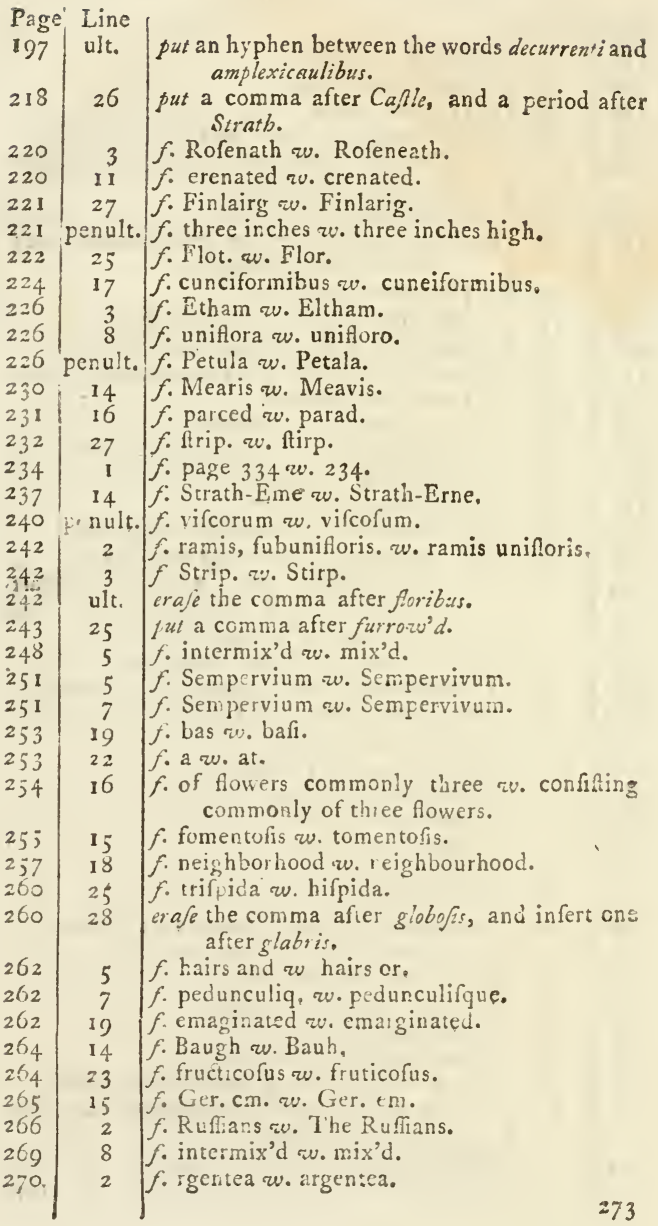




\begin{tabular}{|c|c|c|}
\hline Page & Line & \\
\hline 391 & 12 & f. diphyllus w. diphyllis. \\
\hline & 2 & $f$. and fome foils $w$. and in fome foils: \\
\hline & ult. & $f$. fix feet w. fix feet high. \\
\hline & 5 & $f$. each pinnz $w$. each pinna. \\
\hline & 27 & $f$. greated branched $w$. greatly branched. \\
\hline & 16 & $\begin{array}{l}\text { after the i6th line infert the Englifh name of } \\
\text { Bird's-foot Trefoil. }\end{array}$ \\
\hline II & 12 & e-afe the comma arter caulibus: \\
\hline & 7 & f. Trygina w. Trigyna. \\
\hline & 8 & $\begin{array}{l}f . \text { androfcemum w. androf mum; and } f \text {. try- } \\
\text { gyris w. trigynis. }\end{array}$ \\
\hline 22 & 20 & $f$. nodum w. nudum. \\
\hline 3 & 16 & $f$. longifia $w$. longiffima. \\
\hline & 6 & $f$. with a more w. with more. \\
\hline 1 & 3 & $f$. may giveń $w$. may be given, \\
\hline 33 & 24 & eraie the comma after foliis. \\
\hline+ & 17 & f. giouns w. grows. \\
\hline 34 & 26 & f. Heracium w. Hieracium. \\
\hline 7 & 7 & f. Pilofella w. Piłofellz. \\
\hline 8 & 2 & $f$. repuning $w$. ripening: \\
\hline 4 & 20 & f. caniculatis w. Canaileulatis \\
\hline & 2 & f. Aghtly w. Alightly. \\
\hline & $\begin{array}{r}15 \\
5\end{array}$ & $\begin{array}{l}\text { w. two thirds of the way up it: } \\
\text { f. Serratule } w \text {. Serratula. }\end{array}$ \\
\hline D" & $\begin{array}{l}5 \\
4\end{array}$ & $\begin{array}{l}f . \text { Serratule w. Serratula. } \\
f \text { : pilofa w. pilofo. }\end{array}$ \\
\hline ? & 11 & $f$. pricked w. prickled. \\
\hline 2 & 17 & f. fpecific w. Ipecific. \\
\hline 56 & 6 & $f$. fortaffe $w$. fortaffe: \\
\hline 56 & 24 & $f$. bracter w. bractea: \\
\hline 59 & 2 & $f$. fquarorfis w. fquarrofis. \\
\hline 6 & ult. & $f$. pulie w. palex. \\
\hline 0 & 15 & w. from three to fix inches bigh. \\
\hline & 22 & $f$. feminieis w. femineis. \\
\hline 70 & 24 & $f$. one plant $w_{.}$on one plant. \\
\hline 79 & 6 & f. Petafites aw. Petafites. \\
\hline & 4 & $\begin{array}{l}f \text {. fudorific alexipharmic w. fudorific and } \\
\text { alexipharmic. }\end{array}$ \\
\hline 78 & 19 & f. fefile w. fellile. \\
\hline ? & 2 & f. radicated $2 v$. radiated. \\
\hline 80 & 3 & $f$. tridente $w$. tridentated. \\
\hline 8 & $\begin{aligned} 12 \\
6\end{aligned}$ & $\begin{array}{l}\text { w. threc or four feet bigh. } \\
f \text {. finnated w. finuated. }\end{array}$ \\
\hline & 23 & $f$. is little hairy $w$. is a little hairy. \\
\hline & 10 & $f$. membraneous w. mernbranaceolis. \\
\hline
\end{tabular}




\section{ERRORS of the PRESS.}

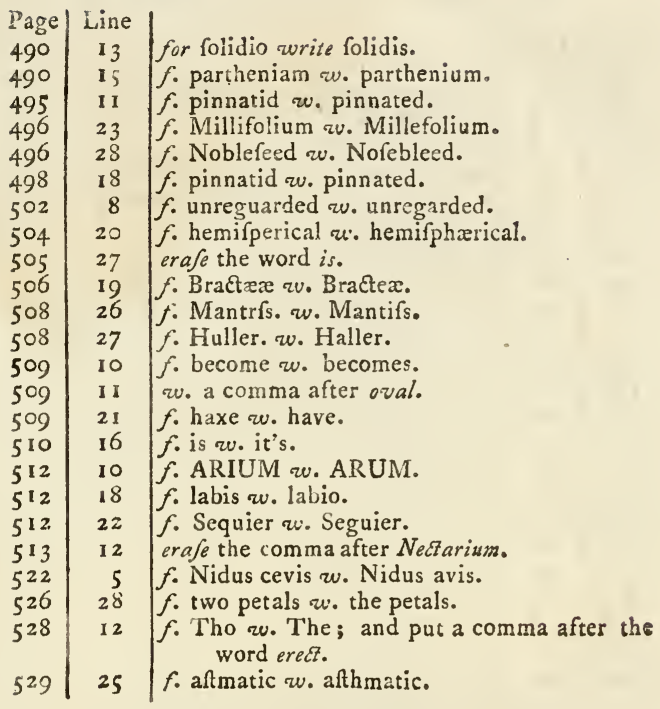

\section{O L. II.}

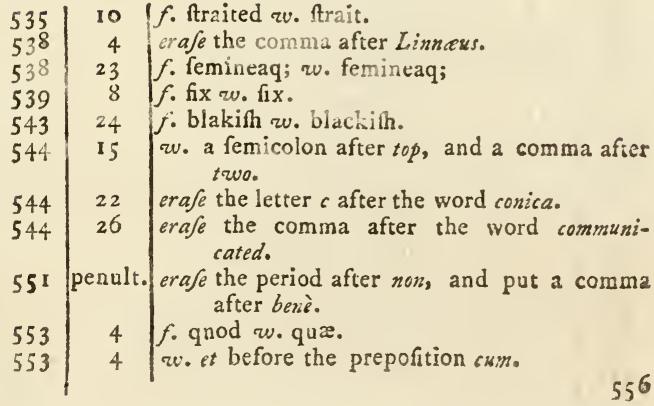




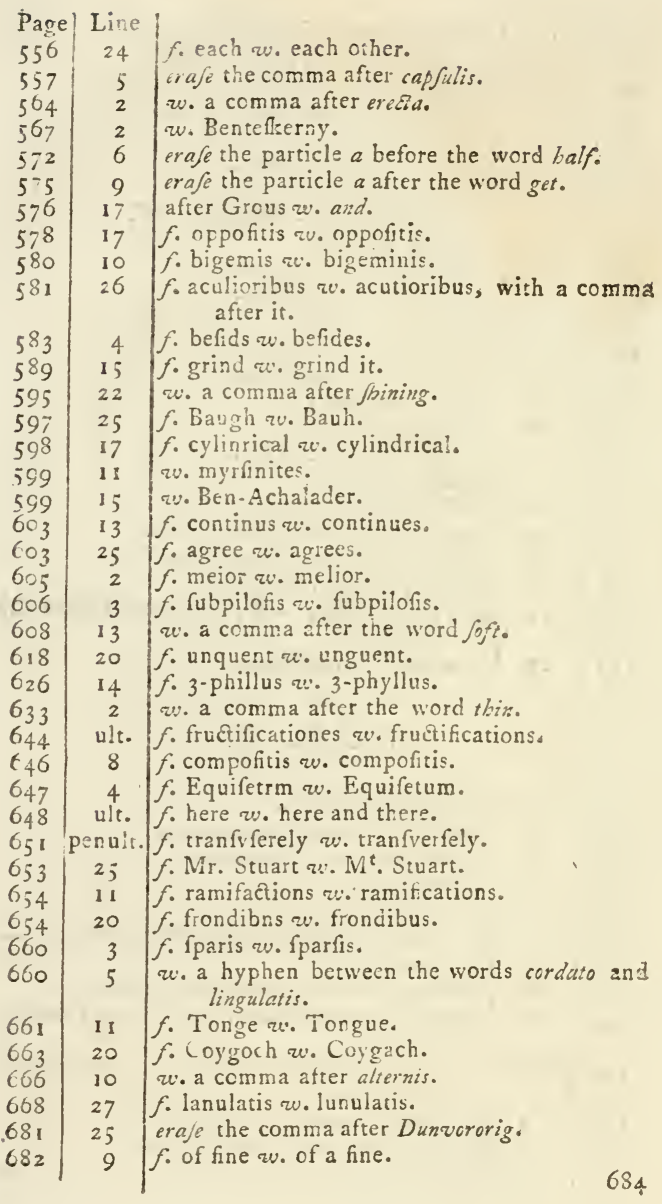




\section{ERRORS of the PRESS.}

Page' Line

$684 \mid \mathrm{I}_{3} f \mathrm{f}$ a rind $\%$ a kind.

684 penult. $f$. at the end $r v$. at the bead.

68617 f. foliolis $z$. foliofis.

6935 f. contralibus s. centralibus.

6943 f. Arft w. firft.

$6979 f$. vafculorum av. vaículofum.

697 I2 f. pedunculatumh w. pedunculatum.

$698 \quad 14 f$. timplice w. fimplici.

$70220 \quad f$. anthera $w$. antherr.

704 penult. av. a comma after the word burf.

\begin{tabular}{l|l|l}
708 & 27 & $f$. fimplice $w$. fimplici.
\end{tabular}

III 25 erafe the word pendulis, which is twice printed,

$717 \quad 15 f$. fphœricis w. Sphricis.

717 ult. $f$. fphœrical w. fpharical.

71814 wo inverted conical with a hyphen and not a comma between them.

718

719

8 f. near a cylindrical w. nearly of a cylindrical.

$10 f$. over, lower w. over, and lower.

\section{$17 f$. fperculo rv. operculo.}

$5 f$. lente acuta w. lente aucta.

$18 f_{0}$ invifible $r$. vifible.

9 erafe the comma after furculis.

$14 f$. half an inch w. half an inch bigb.

11 so. a comma after thin.

17 z. a comma afrer ramefis.

17 f. fimplicifia rv. fimplicirima.

26 f. lancelate w. lanceolate.

25 w. yellowifn, green, with a hyphen and not

a comma between them.

$10 f$. qualiiy $s u$. quality.

$12 \%$ and before the word arije.

4 f. erect if tufts $\%$ erec if in tufts.

$4 f$. curved $w$. covered.

$10 f$. creep and thoot w. creep and thoot out.

10 $f$. they are not $w$. they are not $f o$.

13 ff. their ufes $q v$. it's ufes.

$9 f$. largen the su. largelt of the.

16 f. alternately, pinnase $v$. alternatcly-pinnate.

$f$. that genus av. this genus.

$f$. authera $w$ anthera. 


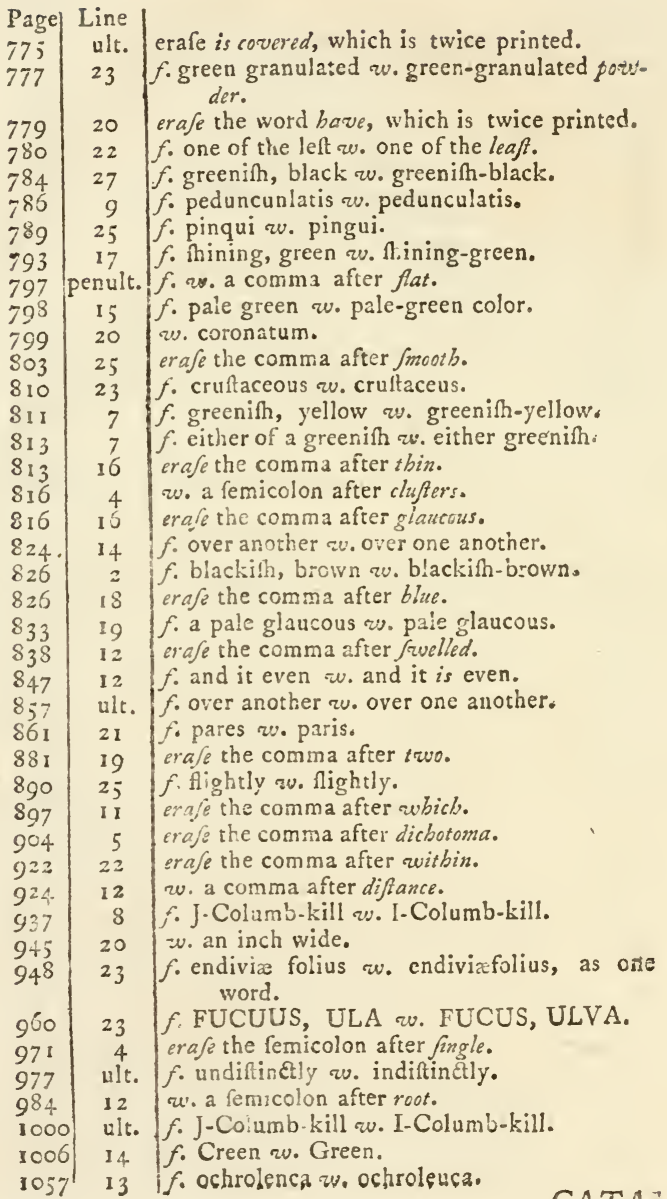


$(\operatorname{xxxy})$

C A $\quad$ T A $A$ L O G

OF THE

F $\quad I \quad G \quad U \quad R \quad E \quad S$ 。

V O L. I.

B I $R$ D $S$.

Plate I. Page 17. SPREY.

II. 20. Hooded Crow:

III. 34. Knot. Hebridal Sandpiper?

IV. 35. Long-legg'd Plover.

V. 40. Black Gull. Black-headed Gull.

\section{P L A N T S.}

Ranunculus reptans, p. 289. in the frontifpiece of the firft volume.

VI. 77 . Pinguicula villofa. 543. Carex pauciflora. p. 543: vol. II.

c 2

Plate VII 
Plate VII. Page 134 Pulmonaria maritima.

a. The flower with its calyx.

b. The corolla opened in order to fhew the number and pofition of the ftamina.

VII!. I81. Anthericum calyculatum.

๑. The flower expanded, with the peduncle annex'd.

124. Ruppia maritima.

IX. I83. Juncus trifidus.

I86. Juncus triglumis.

X. 199. Epilobium alpinum.

24.2. Ceraftium latifolium.

X. 2:5. Arbutus alpina.

a. With Howers.

b. With fruit.

216 . Arbutus uva urfa.

6. With flowers.

d. With fruit.

XII. 22 I. Saxifraga nivalis.

a. The corolla expanded of the natural fize.

b. The two germina.

227 . Silene acaulis. 
Plate XIII. Page 266. Rubus chancemorus.

a. The plant in flowẹr.

b. The fruit.

286. Thalifrum alpinum.

XIV. $\quad 32$ I. Bartfia vifcofa.

a. The calyx with the pif til in the centre.

b. A fide view of the corolla.

c. A front view of the fame.

d. a front view of the upper lip.

e. A front view of the lower lip.

$f . g$. front and portern views of a magnified antbara upon its filament, before it has difcharged its pollen.

b. $i$. The fame as the two latt, after the cnibera has burft and difcharged its pollen through two oval apertures.

$k$. The piftil, confinting of the germen, 1tyle, and figme. 
Plate XV. Page 347. Cardamine petræa. 353. Sifymbrium monenfe. 390. Orobus fylvaticus. a. The plant in flower. b. The pods. XVII. 401. Aftragalus uralenfis. XVIII. 434. Hieracium alpinum. XIX. 448. Serratula alpina. XX. 470 . Gnaphalium dioicum. 471. Gnaphalium alpinum. XXI. 505. Lobelia Dortmanna.

\section{O L. II.}

Agroftis pumila. App.p.108 : to be placed in the frontif. piece of the $2 \mathrm{~d}$ volume. a. A fingle flower magnified.

XXII. 520. Satyrium repens.

a. A fide view of the co: rolla.

6. A front view of the fame.

XXIII. 523. Ophrys corallorhiza in its feeding ftate.

a. The flower on its pe: duncle.

XXIV. 544. Carex incurva,

87. Schœnus compreffus. A variety with a ftalk nearly round, 


$$
\begin{aligned}
& \text { round, and dark ferrugi- } \\
& \text { neous glumes. }
\end{aligned}
$$

PlateXXV.Page 575. Betula nana.

XXVI. $\quad 826$. a. Lichen plumbeus.

827. 6. Lichen Burgeffii.

c. Part of a leaf with a mield magnified, in order to reprefent diftinctly the crown about the rim of the Thield.

XXVII. 933. Fucus palmatus. XXVIII. 938. Fucus efculentus.

a. A young leaf.

XXIX. 946. Fucus ligulatus. XXX. 949. Fucus prolifer.

a. A portion of the leaf of the natural fize, fhewing diftinctly its proliferous manner of growth.

b. An extreme fegment of the fame leaf magnified, fhewing the warty fructifications, and a piece of the Fiuftra piloja.

XXXI. $\quad 962$. Fucus verticillatus. 1069 . Lycoperdon nigrum. XXXil. 964 . Fucus pygmæus.

a. $b$. Leaves of the natural fize. 
c. A leaf of the natural fize in fructification.

d. The extremity of one of the fegments magnified, fhewing diftinctly the fructifications.

e. A clufter of the plant, fhewing its manner of growth.

948. Fucus Endiviæfolius.

$f$. The plant of the natural fize.

$g$. The extremity of one of the fegments magnified, fhewing the fructifications.

XXXIII. 974. Ulva laciniata.

A. The plant of its natural fize.

a. The extremity of one of the fegments, fhewing the minute feeds imbedded in the membrane.

XXXIV. 975. Uiva dichotoma.

A. The plant of its natyral fize.

a. The extremity of one of the fegments magnified, 
nified, hewing its reticulated fubftance, and the fuppofed feeds im: Append: bedded in it. PlateXXXV.P. Iog6. Sifon verticillatum.

A. A diminifhed figure of the plant.

b. The partial involucrunt a little magnified.

c. The corolla a little mag: nified.

d. A feed a little magni, fied.

6. A fingle whirl of the capillary foliola, of the natural fize.

The Second Volume begins at Page 53I. Clafs MONOECIA. 



\section{CLASS I. QUADRUPEDS.}

\section{HOOF E D.}

$\begin{array}{lllll}H & \mathrm{O} & \mathrm{R} & \mathrm{S} & \mathrm{E} .\end{array}$

1. Generous. Br. Zool. I. I. ERsE. Stallion, org each. mare Lair, capul. gelding, each, mare, foal Searrach.

THE predominant color grey, or white;

1. fmall in the highlands and illands: the fmalleft in the ine of Tirey and the Sbetland ines. Fames I. improved the breed of his country by introducing horfes from Hungary. Boetbius, $35^{2}$.

2. Afs.

Equus afinus Lin. fyft. 100.

Afs, Br. Zool. I. 11. Syn. quad. No. 3. Er. afal.

A SSES very rare in Scotland: none in the 1 North.

\section{O X.}

2. Domeftic.

Ox, Br. Zool. I. 15. Syn. quad. No. 4 .

Er Bull Tarbb. Cow. B̀̀, mart. Ox Dainb. Calf. Laogh.

$\therefore$... YUltivated in all parts; the great article I of trade in: the North, and molt of

The animals marked thus * are alfo found in the illands. 
the inles: largeft of the inland cattle thofe of Skie: often hornlefs in the highlands. During Winter feed on fea-wrack, fuch as tang, \&c. and tho' out of fight of the fea, will regularly feek the Thores "at the recefs of the tides. The ftags of the inlands do the fame.

Wild.

NONE at prefent found unconfined. 1V The offspring of the original breed ftill preferved in the parks of Hamilton and Drumlanrig; and alfu in that of CbillingbamCafte, in Nortbumberland. Are of a milkwhite color; have black ears, muzzles and orbits; horns fine, and bending out; nender legs; very wild; and Aly like deer at the fight of man; generally on full gallop : very fierce, and dangerous when wounded, attacking their affailant with great fury. Never approach the cattle zyards, but when compell'd by hunger in very fevere weather: always lie out; their hides on that account tougher, and more valued by curriers than thofe of tame cattle. The carcals of an ox of this kind weighs $3^{8}$ ftones En lifh, of a cow 28 ftones.

In Boetbius's days wild everywhere: had great manes; I fuppore long hair on their necks and Thoulders, like the wild bulls of $N$. America; now have toft that diftinction: feem to have been the fame with the Bifontes 


\section{( 3 )}

jubati of Pliny, natives of Germany, but which might have been common to the continent, and our inand. Sibbald fays, that in his time a wild white breed was found in the Scottish hills; but differ'd not in form from the common kind. Tame black cattle, in the ine of Canay, have ftill thin ftaring manes along the top of their backs, which reach from the neck up part of the tail.

\section{S H E E P.}

4. Fleecy.

Br. Zool. I. 22. Syn. qued. No.8.

Er. Ram Retthe. Ewe Caoro. Lamb uan. yearling oifg.

TOUND in all parts; fcarcer in the 1 North, as the violent rains difagree with them: the fleeces of thofe in the inand of Fura renuarkably fine, otherwife in general coarfe: the beft in the South: the woul fold into the cloathing parts of YorkßBire. Multitudes of theep reared in E $k$-Dale, and the other Deles : are a great article of commerce: much cheefe made from their milk: in general their faces and legs black; their seeth in fome places, as Boetbius truly fayc, of a gold color; that is to fay covered with a yellow pyritical cruft: I never happened to meet with this accident in heep, but have in thofe of oxen feeding in certain meadows in Blair-Atbol. 


\section{(4)}

The great horned heep of St. Kilda, mentioned by Boetbius,' may have been the Musimon, Syn. quad. No. II.

\section{G O A $\quad$ A.}

5. D meltic.

\section{3:}

\section{E E R.}

6. Stag.

Stag, Br. Zool. I. 34. Syn. quad. No. 38 .

Er, Darib-ficith. lind, Eirid, agh. calf. l.aogh.

TOUND in a ftate of nature over all the 1 Higklands, and in great herds: inhabits alfo the ines of Arran, Fura, Mull, Rum, Skie, Harris and Lewis. Often grows to a great fize: I have heard of one, killed in Braemar, that weighed.18ft. Scotch. Is the principal venifon of the Higblands; lefs coarfe than 
than thofe confin'd in parks in $S$. Britain. Is very deftructive to corn : in Skie the farmer is obliged to watch his crop. The Duke of Argyle has, in fome parts of his eftate, humanely permitted the tenant to deftroy an animal fo noxious to his labors.

7. Roe.

Roe, Br.Zool. I. 39. Syn. quad. No. 43 .

Er. Boc-earba. doe, Maoilfeach, young, meann. yearling, ininnferich.

HOUND in plenty from the wooded banks I: of Lougb-Lomond, to the foreft near Langrwall in the S. of Catbrie/s, in Mull and in Skie. The fkin and horns articles of commerce. Brouze much : fond of the rubus faxatilis, called in Scotland the roe-buck-berry. The fawns, when taken, are with great difficulty reared, eight out of ten dying.

8. Fallow.

Fallow deer, Br. Zool. I. 34. Syn. quad. No. 37 .

TONE wild in Scotland; confin'd to 1 parks, and not common : probably introduced there from Denmark by Fames VI, in his return from his vifit to that court in 1589; for Moyjes, a fervant of his, mentions in his memoirs, under the year 1586 , that his majefty one morning pafied over from Leith to Falkland, and had along with him a tame fallow deer, prefented to him by the 


\section{( 6 )}

Queen of England: a proof of its being a great sarity at that time.

\section{H O G.}

9. Common.

Br. Zool. I. 4 I. Sin. quad. No. 54 . Er. Boar, Torc. Sow, Muc. Pig, Uircein.

CCARCE in the highlands and inlancts, $\checkmark$ from the difficulty of rearing them, by reafon of the want of acorns in one part of the year, and grains from brewings, and of other food, the reft. Are detefted by highlanders: in the North moftly cultivated in Catbness; a fmall fierce race, with long pricked ears, high backs, long briftles, and fiender nofes: in that open country are tethered in every field. Much bacon exported out of that county; alfo from the Orknies.

\section{DIGITATED QUADRUPEDS.}

\section{O G.}

10. Faithfuli.

Er. Dog Madagłs Cù. Bitch Galladh. Wheip Cuilean.

HE more fingular varieties found in
Scotland, are the HighlandGre-bound; now rare: is large, frong, deep chefted, and covered with very long 


\section{( 7 )}

long and rough hair: was in great vogue 15 old times, and ufed in great numbers by the chieftains in their magnificent huntings. Is the kind Boetbius calls, genus venaticum cìms celerrimum, tam audacifimum. Er. mial-cbu.

Terrier. The breed in the ine of Skie particularly good: much encouraged in moft parts, for the deftruction of foxes. Er. Abbag.

Blood-bound. Now in difufe; formerly much cultivated, efpecially on the borders, where it gave furprizing inftances of its fagacity, purfuing and detecting robbers and murderers, even after a flight of feveral miles. Inhabitants on the Englifh borders were bound to keep fo many dogs of this kind in every ditrict. They were called Slough or Slothe hounds, from their following the not or track of men or cattle.

31. Fö.

Br. Zool. I. 58, 3det. No. 11. Syn. quad. No. 112. Er. Sionnasb, Ba!gaire.

NWAKMS in many parts of the high$\checkmark$ lands : fo deftructive to theep as to oblige the farmer to houfe them at night; will kill even goats. Ale not to be extirpated, by reafon of the vaft rocks and mountains. None in the Orkney or Sbetland inles, nor in any of the Hebrides, except Skie.

C A T. 


$$
\begin{aligned}
& (8) \\
& \text { C A } \mathrm{A} \text {. }
\end{aligned}
$$

12 Tame. $^{*}$

Wiild.

13. Common.

8. Fitchet.
Domeftic Cat, Br. Zool. I. 45, E. Pifeag.

CUltivated every where. In fuperftitious 1 days the favorite form affum'd by witches. Vide witches of Tburjo, Tour irs Scotiand.

Br. Zool. I. $47 . S_{y} n$. quad. No. 133 .

Er. Cat-finadluich.

$\triangle$ BOUNDS in all parts of the highlands, 11 and in fome of the ines. Mort deitructive to game.

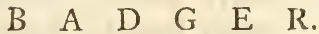

Br. Zool. I. 64, iv. tab. 100. Syn. quad. No. 142. Er. Broc.

TOUND in feveral parts of Scotland; none in the inlands.

\section{W E E S E L.}

Br. Zool, I. 77. Syn. guad. No. 152. Er. Fòclan.

Nhabits moft parts of the main land,

1 and the inle of Bute.

15. Pine-martin. 
15. Pine-martin.

16. Mërtrick.
Br. Zool. I. 81. Er. Tagban.

7 HIS fpecies is found in the pine-forefts, 1 and takes poffeflion of the holes made by woodpeckers. Is diftinguifhed from the other by it's yellow throat, and hav.ng the fineft fur.

Martin, Br. Zool. I. 79. $3^{d}$ ed. No. ${ }_{5}$, Syn. quad. No. 154 .

HOUND in many parts of Scotland; and, according to Martin, in Harris.

Br. Zool. I. 84, iv. tab. 101. Syn. quad. No. $15^{1}$.

COMMON in Scotland. In the highlands 1 commonly turns white, or becomes in the Winter an Ermine. Inhabits alfo Ilay, perh.aps other inles.

18. Weefel.

Br. Zool. I. 82, iv. tab. 10r. Syn. quad. No. $15^{\circ}$ Whitred, Lib. Scot. 11. Er. Neas.

T Saw it in a white ftate in the inle of Ilay:

1 a common accident in Sweden, where it is called Snomus. 


\section{(10)}

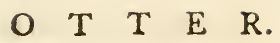

19. Otter.

Br. 2ool. 1. 67, iv. tab. 100. Syn. quad. No. 173.

Er. Doren, Dir-cbin, madagb donn.

YER.Y common in Scotlana'; abounds in the Hebrides, the Orknies, and in Sbetland; in the laft are called Tikes. A fmall trade is carried on with their fkins, which are fold from 4s. to 6s. a-piece.

Sibbald * fpeaks of a great kind, which he calls the fea-otter; and fays is larger, and has rougher fur than the other: probably only a variety; perhaps the Latax of Ariftotle. Vide Br. Zool. I. 69 .

\section{H A R E.}

vo. Connon.

Br. Zool. 1. 87. Syn. qual. No. 18.4.

Er. maigheach, Gearr-fliadb.

$\mathrm{H}^{\mathrm{REQUENT}}$ in all parts of Scotland: found in the ine of Bute: none in Arran : in the ifle of Ilay a fmall fort, dark colored, and a bad runner. The other inlands deftitute of hares.

* Hifl. Fife, 49. 
21. Alpine.

22. Rabbet.
Tour in Scotland, 2d ed. Pb. Tr. 4, vii. p. 343. S,n quad. No. 184 .

Er. maigbeach gheal, maigbeacb mbonai.

Nhabits the fummits of the highent high -

1 land hills, along with the Ptormigans.

Is lefs than the common hare, of a greyer color, or lefs ferruginous : a bad runner; often ftops fuddenly in the midit of its courfe : when purfued fhelters beneath the loole ftones, or in clifts of rocks : never defcends into the plains, or mixes with the common hare, which is frequent at the bottoms of the fame hills. In Winter turns white, the tips of the ears excepted; in Spring refumes it's grey color: the ears fhorter, the hind feet longer, in proportion, than thofe of the common hare: the hair much longer and thicker than in the latter, to protect it againit the feverity of the cold.

Br. Zool. I. 90. iv. tab. 47, 3d at. No. 22. Syn. quad, No. 186. Er. Coinean.

Nhahits all the inands, even the rock of 1 Ailfa: found in the Orknies in myriads. They caufe great hifting of the fands, by burrowing in them; but the value of their fkins (a great article of commerce there) fcarce counterbalances the damage. This animal, 


\section{(12)}

animal, the otter, brown rat, moufe, fetidfhrew, and feal, are the only quadrupeds of the Orknies, except the domeftic.

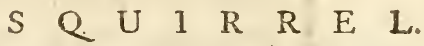

23. Common.

Br. Zool. I. 93. Sjnn. quad. No. 206. Er. Feòrag.

CCARCE in Scotland: a few in the woods $\checkmark$ of Strathppey.

\section{R A T.}

24. Black.

Br. Zool. I. 97. Syn. quad. No. 226. Er. Radan.

Nterdicted Sutberland; but fwarms in

1 Catbness and Rofsßire. Vide Tour in Scotland.

24. Brown. Norway rat, Br. Zool. I. 99. Sy'n. quad. No.227.

Ntroduced here within thefe 60 years:

1 place uncertain, found as far as the Orknies.

26. Water.

Br. Zool. I. 101. Syn. quad. No. 228.

27. Moufe.

Br. Zool. I. 105, iv. tab. 102. Syn. quad. No. 229.

E.r. Luch-Tbigbe. 
28. Short-tailed Moufe. ,

30. Fœtid.

31. Water.
29. Field-M.

Br. Zool. I. 104. Syn. quad. No. 233.

Er. Luch-mbonaidb.

Br. Zool. I. 103. Syn. quad. No. 230.

\section{S H R E W.}

Br. Zool. I. I12. syn. quad. No. 235.

Er. Dallag an flbraoich.

Br. Zool. iv. tab'. 102. Syn. quad. No. 236.

Er. Lucb-uifque.

LAVELLAN of fome places: fuppofed to be noxious to cattle.

\section{O L E.}

Br. Zool. I. 108. Syn. quad. No. 241.

Er. Famb, Uir-reathabh.

A MONG the ines only in Bute: a praife A to it's foil.

\section{$\begin{array}{lllllll}U & R & C & H & I & N\end{array}$}

33. Common.

Br. Zool. I. 106. Syn. quad. No. 247.

Er. Gràineog.

A $\mathrm{N}$ innocent animal; thould be freed 11 from perfecution. Not found beyond 
yond the Tay; perhaps not beyond the Forth.

\section{PINNATED QUADRUPEDS.}

S E A L.

34. ज̈reat.

Syn. quat. No. 266.

A BOUT the rock Hifkyr, and other $A$ parts of the Scottiff coaft.

35. Common.

Br. Zool. I. 71, iv. tab. 48. Sym. quad. No. 265 . Er. Kor.

SWARM amidit the ines and all the $S$ coafts. In fome places the fkins and oil an article of commerce. The WaLRUS, Syn. quad. No. 263, mentioned by Sibbald, among the Scottifh animals, is now unknown.

\section{WINGED QUADRUPEDS.}

\section{B A T.}

36. Common.

$$
\begin{aligned}
& \text { Br. Zool. I. 1l4. Syn. quad. No. } 291 . \\
& \text { Er. Altag, Dialtag. }
\end{aligned}
$$




\section{(15)}

${ }_{37}$ Long-ear'd

Br. Zool. I. 116. is. tab. 103. Syn. quad. No. 29z:

\section{EXTINCI QUADRUPEDS.}

$W^{O L F}$, madagh alluidh, a peft to the flocks in N. Britain in fames VIth's time: the laft killed about the year 1680 . Br. Zool. I. 6r.

$B^{L A R}$; Caledonian bears exported to Rome on account of their fuperior fiercenefs*. They continued in Scotland 'till A. D. 1057, when Malcolm III. permitted a Gordon to carry three bears heads in his banner, for his prowefs in deftroying one that made great savages in the country.

3. 2. 200\%. I. 63. 


\section{(16)}

\section{L A S S I. B I R D S.}

Div. I. LA ND-BIRDS.

\section{RAPACIOUS.}

$$
\text { F A L C O N. }
$$

38. Black-Eagle.
Ringtail Eagle, Br. Zool. I. 124. Er. Foluir-dbubb.

1. 05 T deftructive to deer, white hares, $1 \sqrt{1}$ and ptarmigans : has almoft deftroyed the deer of the ine of Rum. In Runnocb eagles were, a few years ago, fo very numerous, that the commiffioners of the forfeited eftates offered a reward of five fhillings for every one that was deftroyed: in a little time fuch numbers were brought in, that the Honourable Board reduced the premium to three Rillings and fixpence: but an advance in proportion as thefe birds grew fcarcer, might in time perhaps effected their extirpation.

Ravens and hooded-crows are the jackals to eagles: the croak of the raven, or the affemblage of the crows about a carcafs, is certain of bringing an eagle to the fpot, as the perfons who fhoot thofe birds for lake of the rewards tefify. 



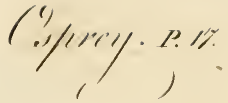

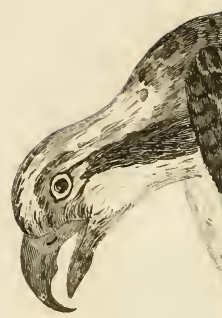

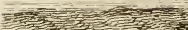

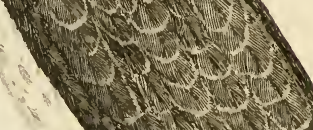

N 2 (N)

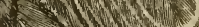
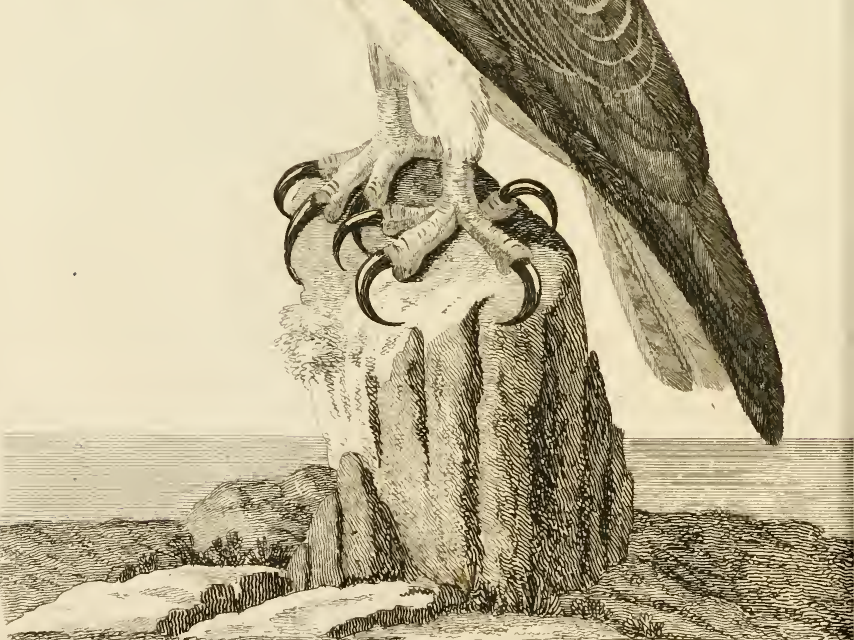

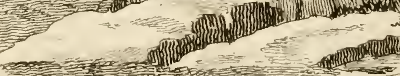

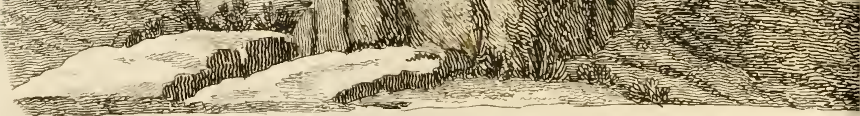


39 Seä-E.

\author{
Br. Zool. I. 126, iv. $t a b .5$ 1.
}

REEDS in ruined towers in the inands 13 of the lakes? deferts them in Winter.
Erne, $\operatorname{Br}$. Zool. I. 131, tab. iii.

$\mathrm{N}$ the Orknies is a kind with only the root 1 of the tail white: perhaps a young bird.

Ofprey.

Br. Zool. I. 1zS. Er. Folzir' -uifg'.

4'Gyr-falcon

Br. Zool. I. 135, tab. iv.

42 Peregrinefalcon.

43 Gentil-f.

$$
\text { Br. Zool. I. 136, iv. } t a b .52 \text {. }
$$

A Trained bird of this fpecies, with bells, A and filver rings to the taffels, infcribed Kilivie Angusfoire, was taken near my houfe, Sept. 26, 1772, about ten o'clock in the morning; and which eloped from it's mafter the $24^{t h}$ of the fame month.

Br. Zool. iv. tab i. ii.

REEDS in the rocks near Invercauld, and in Glen-more. Trained for the chafe.

A. Animals marked thus $\dagger$ are alfo found in the Orknies. c 44. Gomawk. 


\section{(18)}

44 Goillawk.

45 hile.

46 CommonBuzzard.

47. Moor-B.

48 Hen-har-
rier.

49 Keftril.

jo Hobby.
- $\mathrm{S}^{*}+$
1 Sparrow. Hawk.

52 Merlin.

53 Eagle.
Br. Zool. I. 140. tab. v.

$\mathrm{B}^{\text {REEDS in the foretts of Invercauld. }}$

Br. Zool. I. 141. Er. Clamban gabblach, Croman-lochai.

Br. Zool. I. 143, iv tab. 53. Er. An Clamban.

Br. Zool. I. 146, iv. tab. 5. Bog Gled sibball.

Br. Zool. I. 147. Er. An teunfionn. Hen-harrier, or fem. Bread-cir-íoin.

Br. Zool. I. 149 .

Er. Zool. I. 150.

Br. Zool. I. 1;1. Er. Speir-Beog.

Br. 20ol. I. 153 .

Er. Zool. iv. 10, tab. 6.

AS been thot in FifeßBire: perhaps a

11 migrant from Norway.

54 Long-eared. 
${ }_{54}^{+}$Long-ear'd

55 Short-ear'd

56 White.

$+$

57 Brown.

;8 Tawny.

59 Great.
B. Zool. I. 155.

$\mathrm{I}^{\mathrm{N}}$ the mainland; and alfo in the Orknies. Br. Zool. I 156 .

FTEN feen in Scotland, breeding in the heath : obferved there by Mr. Lee, nurferyman at Hammerfmith.

* * With plain heads.

Br. Zool. I. 157 .

Er. Cailleach oi' che gbeal.

Br. Zool. I. 159.

Er. Cumbacbag cailleacb oi'cbe, coileacb oi che.

$\mathrm{F}^{\text {REQUENT }}$ alfo in the hills of Hoy, in the Orknies?

Br. Zool. I. $15^{8}$.

Could not learn that any fpecies of owl

1 was known in the Hebrides, or in Weft Rosspire.

\section{S H R I K E.}

Br. 2ool. I. 16r. iv. tab. 7 . 


\section{$20)$ \\ II. $\mathrm{P} I \mathrm{I} \mathrm{S}$. \\ C $\quad \mathrm{R} \quad \mathrm{O}$ W.}

Br. Zool. I. 166.

Er. Fitseach.

6r Crow.

Br. Zool. I. 167, iv. $t a b .54$.

62 Rook.

Pr. Zool. I. 168.

Er. Creumbach, Ròcus.

$6_{3}^{*} \dot{+}$ Hooded.

Br. Zool. I. 169.

Er. Feannag.

OOntinues in Scotland the whole year: the only fpecies in the inlands, and great part of the highlands: grows fcarcer the nearer we approach the South: keeps in pairs, except for fometime after the breeding feafon: is moft affectionate to its mate: one that had been fhot was hung by the legs in a tree not remote from the neft; it's companion, after a Thort abfence, returned, and perching over the dead body, obferved it attentively, as if expecting it's revival; at lergth, in a windy day, the corps being put in motion, and fometimes fwung quite horizontal, the furviving bird, deceived by the motion, defcended to it, liept fluttering by 




\section{(2I)}

it for a confiderable time, endeavouring to affirt in it's releafe, uttering a melancholy fcream; 'till finding all it's attempts in vain, at length retired, without ever returning to it's ufual haunts.

64 Magpie.

$\sigma_{5}$ Jay.

66 Jackdaw.

67 Red-leg'd

28 † Cuckoo.

69 Wryneck.

zo Green.
Br. Zool. I. 171 .

Er. Pioghaid.

Br. Zool. I. 172.

Er. Scriachag-cboille.

Br. Zool. I. 175 , iv. tab. 54 .

Er. Cathag.

Er. Zool. I. 197, iv. tab. $5^{\text {S. }}$

Er. Cathag dbearg-cbafach.

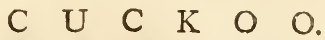

Br. Zool I. 182, iv, tab. 55 .

Er. Cuthag, Cuach.

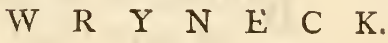

Br. Zool. I. 181. iv. tab. 55 .

\section{W O O D P C K ER.}

Br. Zool. I. 176 .

Er. Lafair cboille. 
41 Great-

spotted.

72 Lefs-fpot.

73 Kingfifher

74 Hoopoe.

75 Creeper.

\section{G A L L I N A C E O S.}

$\begin{array}{lllllll}G & R & O & U & S .\end{array}$

76 Great.

77 Black.

$\rightarrow \stackrel{+}{8} \stackrel{1}{\operatorname{Red}}$
Br. Zool. I. 178 .

Br. Zool. I. 180 . iv. tab. 12.

\section{K I N G F I S H E R.}

Er. Zool. I. 187. iv. tab. 56.

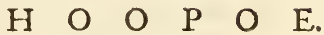

Br. Zool. I. 195. iv. $2 a b .57$.

$\begin{array}{lllllll}C & R & E & E & P & E & R \text {. }\end{array}$

Br. Zool. I. 193. iv. $t a b .57$.
Cock of the Wood, Br. Zool. I. 199.

Er. Capul coille.

FOUND in the forefts N. of Loch-ne/s, but rarely: once frequent in moft of the highland fir-woods.

B'ack Coek, Br. Zool. I. 201.

Er. male, coileacb dubh, fem. Liath-shsare.

Grous, Br. Zool. I. 204. iv. tab. 13.

Er. male, coileach ruagh. fem. Cearc-fbravich.

C 3

79 Ptarmigan. 


\section{(23)}

79 Ptarmigan Br. Zool. I. 206. iv. tab. 13. Er. Tarmachan, Tarmonach.

so Partridge. Br. Zool. I. 208. Er. coleacb-tomain, fem. Ceare-rbomain.

81 Qıа⿰.

Br. Zool. I. 209.

7 HE buftard, according to Boetbius, was 1 fometimes, but rarely, found in the Merch; and at that time called Guftarde: it feems at prefent unknown in N. Britain

Poultry are found plentifully in molt of the iflands: peacocks fucceed very well, as I obferved in Collonsa.

\section{C O L U M B I N E.}

\section{P I G E O N.}

$82 \stackrel{+}{+}{ }^{+}$ Br. Zool. I. 216. iv. tab. 8. Er. Caiuman.

VERY numerous in a wild ftate in the cliffs, impending over the fea, in many of the inles. In Ilay I have feen their dung got with vaft hazard out of the deep chafms on the Weft fide of the inland, by means of a perion who is lowered down to the bottom 


\section{( 24 )}

by a rope. The dung lies many feet thick, is drawn up and ufed fuccefsfully as a manure.

83 Ring-dove

$$
\text { Br. Zool. I. } 221 \text {. }
$$

Er. Smudan, caluman-fiadhaich.

\section{P A S S E R I N E.}

$S$ T A R E.

$\delta_{4}^{*} \stackrel{+}{\text { Stare. }}$

Br. Zool. I. 231. iv. tab. 61.

Er. Druit.

$\mathrm{B}^{\text {REED in }}$ great numbers in the cliffs of Arran, and other inles.

\section{$\begin{array}{lllllllllllllllll}T & H & R & U & S & H\end{array}$}

85 Miffe?.

Br. Zool. 1. 223 .

$86 *$ Fieldfare。

Br. Zool. 225 .

Er. Liatruifg.

NEither fieldfare nor redwing breed in 1 Scotland; rarely feen in the ifles: come accidentally to the Orknies.

$87^{*}$ Throftle.

Br. Zool. I. 226.

Er. Smeèrash. 


\section{( 25$)$}

9S Redwing.

Br. Zool. I. 227 .

so $_{9}^{\dagger}$ Blackbird.

Br. Zool. I. 228. iv. tab 60.

Er. Lon-dulb.

A Variety about Killin, with a black bill.

Sơ Ring-ouzel

Br. Zcol. I. 229, iv. $t a b .61$.

Er. Dubb-cbratge.

9i Waterouzel.

92 Bohemian.

93 Pine.

Br. Zool. iv. iv. tab. 64 .

Nhabits the great pine-forefts of AberdeenBire.

\$4 Crossbill.
Br. Z:ol. I. 230.

Er. Gobb'-uijg, Gobba-dubb.
Br. Zool. I. 173 .

TISITS annually the neighborhood of Edinburgh during Winter, and feeds on the berries of the mountain-afh. Difappears in Spring.

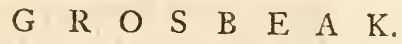




\section{$(26)$}

\$5 Bull-fineh.

Br. Zool. I. 299.

Er. corcan coille, Deargan fraoich.

96. Green.

Greenfinch, Br. Zool. I. 301.

Er. Glaifrun-daracb.

\section{B $\quad U \quad N \quad T \quad I \quad N \quad G$.}

\section{$97 \stackrel{+}{\text { Common. }}$}

98 Yellow.

99 Reed.

$+$

100 Snow.

Br. Zool. I. 318.

Er. Gealag bbuachair.

Yellow-Hammer, Br. Zool. I. 319. iv. tab. 11. Er. Buidheag-bhealai.

Reed-Sparrow, Br. Zool. J. 320.

Snowfleck, Br. Zool. iv. tab. in. Er. Eun an-1-Sneachdiai.

A Few breed on the fummits of the higheit A mountains; but the greateft part migrate from the $\mathrm{N}$. appear firft in the Orknies, thence reach Catbness, but frequently numbers fall wearied into the fhips that are paffing the Pentiand-Firth. Arrive very lean, but foon fatten: they probably come from Spitzbergen, Greenland and Iceland, forced from thence by the Winter: and they are, in Scotland, obferved to precede hard weather. 


$$
\begin{array}{lllll}
( & 27 & & & \\
\text { F I N } & \mathrm{C} & \mathrm{H} .
\end{array}
$$

tol Goldfinch

${ }_{102}^{*}$ Chaffinch

103 Bramb. ling.

${ }_{104}^{+}$Sparrow. $^{-}$

$t$

105 Linnet.

106 Red-

headed.

107 Lefferred-headed. $+$ 108Mountain

sog Spotted.

$+$

I10 Sky.
Br. Zool. I. 303 .

Br. Zool. I. 306.

Er. Bricean-beatha.

Br. Zool. 307 .

Br. Zool. I. 300. iv. tab. 65. Er. Gealbban.

$\mathrm{IN}^{\mathrm{N}}$ the Orknies infelt the corn by thoufands.

Br. Zool. I. 311.

Br. Zool. I. 312. iv. $t a b .67$.

Br. Zool. J. 313. iv. $t a b .67$.

Br. Zool. I. 315. iv. $t a b .66$.

$$
\text { F L Y - C A T C H E R. }
$$

Fly-catcher, Br. Zool. I. 264.

\section{A R K.}

Br. Zool. I. 233 , iv. tab. 62 .

Er. Uijeag. 


\section{$(28)$}

111 Wood.

Br. 7.nol. 1. 235 .

Er. Kiablag-choille.

* +1

112 Tit.

113 Field.

* t

14 White.

11 5 Yellow.

\$16 Grey.

117 Rediftart.

$1{ }^{*} 8^{\dagger} \mathrm{Red}$. breaft.

119 Black-cap
Br. Zool. I. 237.

Er. Rhiabhag-mhonaidh, Glais-eun.

Br. Zool. 1. 238 .

\section{W A G T A I L.}

Br. Zoci, I. 275 . iv. $t a b .62$. Er. Breac-an-t-fil.

Br. Zool. 1. 276 . iv. tab. 62.

Br. Zool. J. 277 .

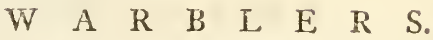 * With tails of one color.}

Br. Zocl. II. 259.

Fir. Ceann-dearg.

Br. Zool. II. 260.

Er. Broinn-dearg.

Br. Zool. II. 262 . 
120 Hedge.

121 Yellow. crefted.
122 Golden.

Hedge-fparrow, Br. Zool. II. 26;.

Br. Zool. II. 266.

R. Latban, of Dartford, in Kent, hewed me a fmall bird, fhot in the highlands; perhaps only a variety of this fpecies: front and underfide a fine pale yellow; wings of a yellowilh white; back and tail pale brown.

Golden crelted wren, Br. Zool. II. 267.

Continues about Edinburgh throughout the year: crores annually to the Sbetland ines in Summer; breeds, and returns before Winter : a long flight for fo fmall a bird, the Orknies, the neareft land, being fixty miles diftant.

i23 Wren.

Br. Zool. II. 268 .

Er. Dreatbann.

124 Sedge.

Willow lark, Br. Zcol. II. 24I. iv, tab. $x$.

* With tails of two coiors.

Br. Zool. II. 269 . 
125 Winchet.

\section{Stone-} chat.

128 Whitethroat.

129 Great.

130 Blue.

331 Cole.

132 Longtailed.

*

133 Houfe.

134 Martin.

${ }_{135}^{\dagger}$ Sand.
Br. Zool. II. 271 .

Br. Zool. II. 272 .

Er. Cloichearan.

Br. Zool. 1I. 274 .

T I T M O U S E.

Br. Zool. II. 324, iv. tab. 68 .

Br. Zool. II. 325. iv. tal. 68.

Br. Zool. II. 326 . iv. tab. 68 .

Er. Cailcbeag cheann dubb.

Br. Zool. II. 327 .

S W A L L O W,

Br. Zool. II. 24z. iv. tab. g.

Er. Gobblan.gaoitbe.

Br. Zool. II. 243.

Br. Ziool. II. 244.

Er, Gobblan-gainbbich. 
136 Swift.

Br. Zool. II. 245 . iv. $t a b .9$.

\section{G O A T S U C K E R.}

37. Goatiucker.
Br. Zool. II. 246. iv. tab. 63 .

SEEN as far North as the banles of Locbmari.

\section{Div. II. W A T E R - F O W L.}

VII. W A D E R S.

\section{$\mathrm{H} \quad \mathrm{E} R \mathrm{O}$.}

Br. Zool. II. 339. fem. 340. tab. vi.

Er. Corra-riatbach. Corra-ghlas.

GREAT numbers breed in the inand in Locb-Guirm, in Ilay.

139 Bittern.

Br. Zool. II. $34^{2}$.

Er. Bubaire.

\section{U R L E W.}

i ${ }^{\dagger}$ Curlew.

Br. Zool. II. 346. tab. viii.

Er. Guilbownach. in Scotsh, whaps. 
r41 Whin brel. $+t$

142 Woodcock.
Br. Zool. II. 347 . iv. $t a b \cdot 70$.

REEDS in the heath of the highland hills, near Invercauld.

\section{$S \quad N \quad I \quad P$ E.}

Br. Zool. II. $34^{8}$. iv. $1 a b .14$.

Er. Coilleach-cuilie, Crom-nan duilleag.

THESE birds appear in flights on the 3. E. coalts of cotland, about the end of Oriober, and fometimes fooner; if fooner it is a certain fign of the Winter being early and fevere; if later, that the beginning of the Winter will be mild. Woodcucks make a very fhort ftay on the E. coafts, owing to their being defliute of wood; but fome of them refort to the moors. They continue arriving in fusceflion for near a month, and in every county in Scotland (where they are found) fly regularly from Eaft to Weft.

Appear abcut Toymoth, which is pretty central, in the beginning or middle of $\mathrm{No}$ rember; continue there in plenty 'till the midule or latter end cf Iriturch, according to the miltnefs or rigor of the feafon, and then difpppear at once. They do not reach the coafts of Niber-Loin, the TWeft coaft of Argalckire, 'till December or Genuary. Woodcocks are very rarcly feen in Catbne/s; they feem 



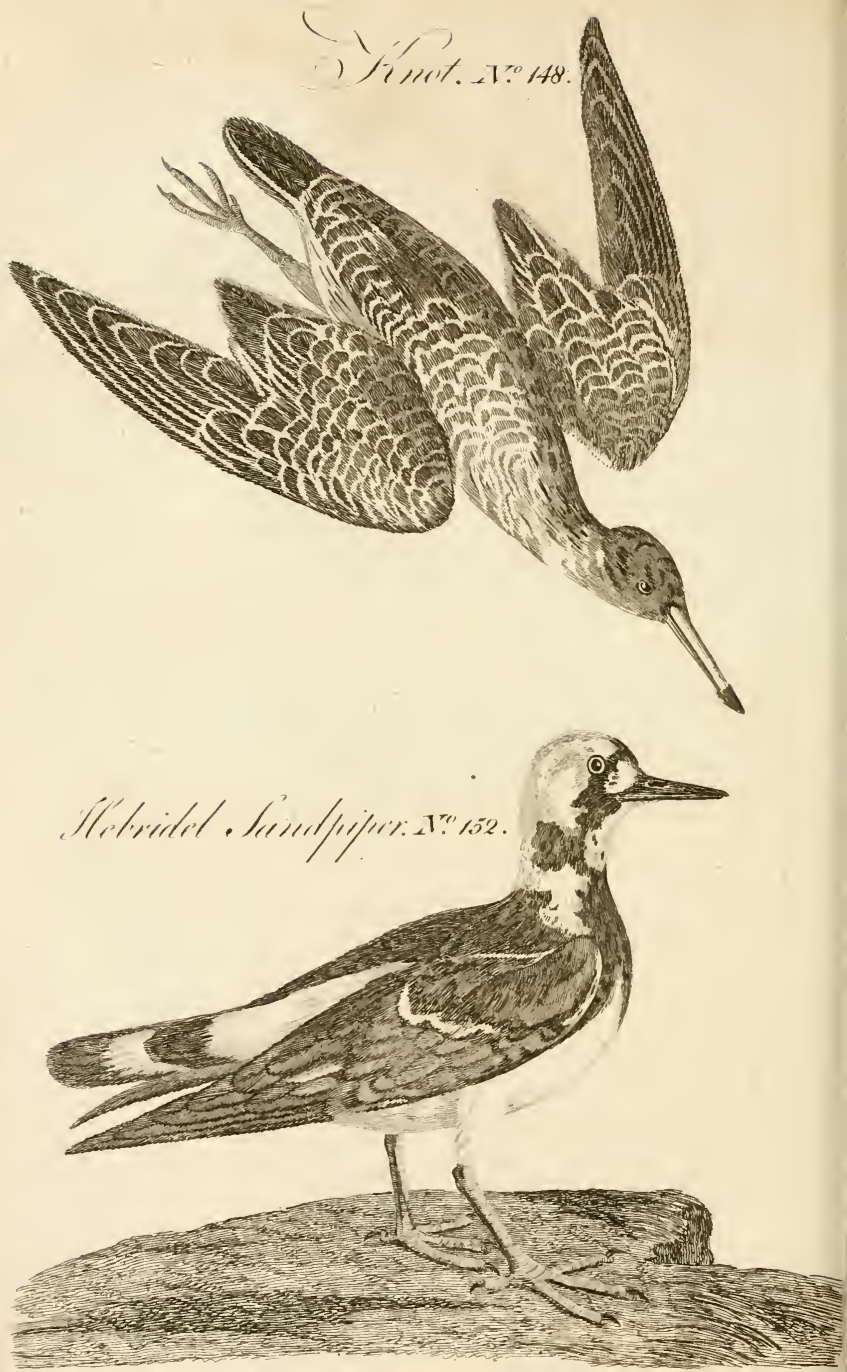




\section{( 33 )}

feem to gradually decline in numbers towards the $\mathrm{N}$. and $\mathrm{N}$. Weft : are uncommon in the ine of Lewis; and Mr. Low acquaints me, that they are fo fcarce in the Orknies, that he does not remember that above one or two have been fhot there. It does not appear that they breed in any part of Nortb-Britain.

143 Redidhanks

Br. Zool. II. 368. iv. tab. 14.

${ }^{*}{ }^{\dagger}{ }^{\dagger}$ Snipe.

Pr. Zool. II. 358. iv. tab. 71.

Er. Eun-ghurag, Cromain-l.oin, mennan-aitbir.

I45 Jack.

Br. Zool. II. 359. iv. táb. 71 .

146 Lapwing.

$\begin{array}{llllllllll}S & A & N & D & P & I & P & E & R & S\end{array}$

Br. Zool II. 360 .

Er. Curcag, ailbarean-luacbrach.

147 Grey.

Grey Plover, Br. Zool. II. $36 \mathbf{2}$.

$148 \mathrm{Knot.}$

Br. Zool. II. 366 .

149 Alh-co-

Br. Zool. II. 367 .

lor'd.

$150 \mathrm{Red}$ ?

Br. Zool. iv. tab. 72. This perhaps a young bird, or va. riety?

$B^{I L L}$ nender, and black : head, back, leffer coverts of the wings, and the fcapulars, 


\section{( 34 )}

dull ferrugınous, fpotted with black : the greater coverts tipt with white: quil feathers dufky, exterior edge of fome of them white : breaft reddifh brown, mixed with dufky: belly and vent white: tail cinereous : two middle feathers the largeft : legs black.

Communicated by the late Doctor David Skene, of Aberdeen.

Is Turn-

$\left\{;{ }^{*} \dagger^{\dagger}\right.$ Hebrid 1 flone.

Er. Zool. II. 370 .

Tringa interpres. Lin. Sif. 248 . Faun. Juec. No. 178 . Edrw. $14 \mathrm{r}$.

GIZE of a thruh: forehead, throat and $\$$ belly white : breaft black: neck fur. rounded with a black collar; from thence another bounds the fides of the neck, and paffes over the forehead: head, and lower part of the neck behind, white; the firft ftreaked with dutky lines: back ferruginous, mixed with black : coverts of the tail white, croffed with a black bar: tail black, tipt with white: coverts of the wings cinereous brown; the lower order edged with white: primaries and fecondaries black; the ends of the laft white: tertials ferruginous and black: legs rather Mort, and of a full orange.

153 Commen Br. Zool. II. 373 . 



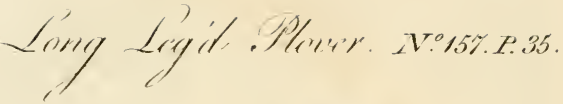

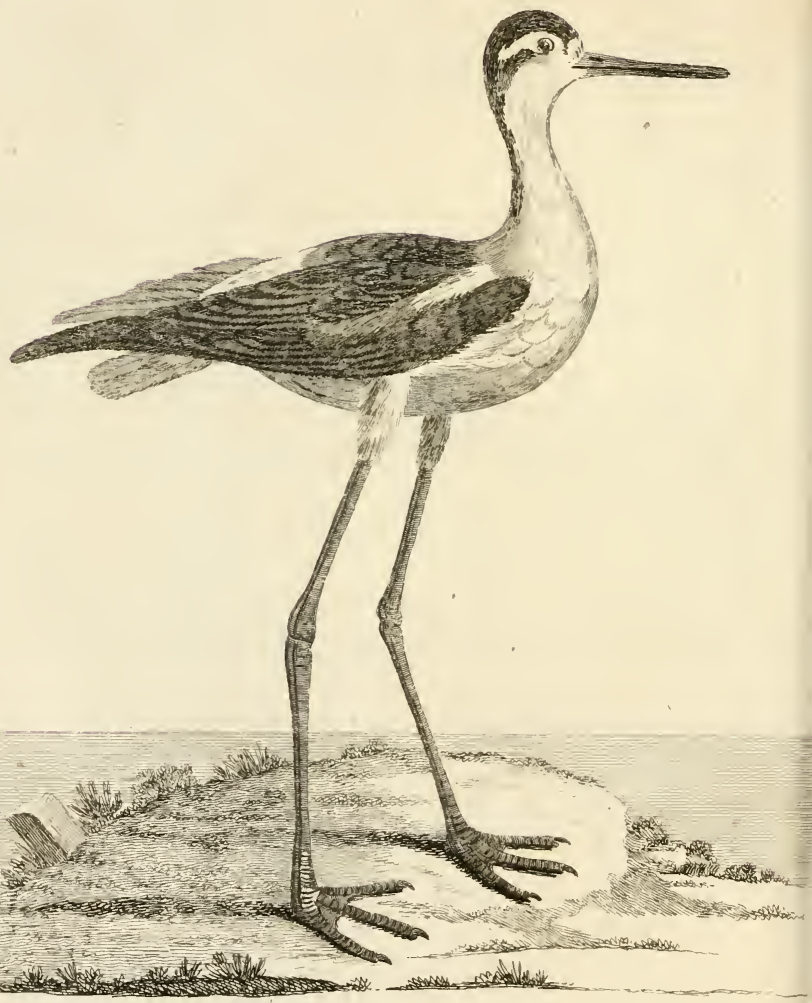


154 Dunlin.

Br. Zool. II. 374 .

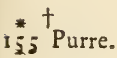

Br. Zool. II. 374 . iv. $t a b, 16$.

${ }_{15} 6^{\dagger}$ Green.

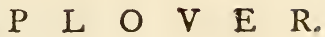

Br. Zool. II. 379. iv, tab. 72 .

Er. Feadag.

$B^{\text {REEDS on all the heathy hills of the }}$ $\mathrm{B}$ illands and highlands.

157 Long.
leg'd. Br. Zool. II. 380. Sib, biff. Scot. lib. III. 18. tab. xi. xiii.

158 Dottrel.

Br. Zool. II. $3^{81}$. iv. tab. 73 .

Er. Amadan-mointich.

$B^{\text {REEDS on feveral of the highland hills. }}$

$.599^{\dagger}$ Collar'd.

Sea Lark. Br. Zool. II. $3^{8} 3$.

Er. Trileachan-traighe.

O Y S T E R C A T C H E R.

$160{ }^{\dagger}$ Pied.

Pr. Zool. II. 376 .

Er. Gille-bride.

\section{R A I L.}

16r Water.

Br. Zool. II, 38; iv. tab. 74 .

D 2 .

GALLR. 


\section{$\left(3^{6}\right)$}

$16_{2}^{+}$Crake.

163 Common

$16_{4}^{+}$Grey.

$16 \varsigma^{\dagger}$ Red.

i66 Common

167 Great.

168 Geneva.

\section{G A L L I N U L E.}

Land-rail, Br. Zool. II. 387 . iv. tab. 74 . Er. Gearradb-gort, Treun-re-Treun.

Water-hen, Br. Zool. II. $3^{88 . ~ i y . ~} t a b .76$.

\section{PIN NATED FEET. \\ $P \quad H \quad L \quad A \quad R \quad O \quad P \quad E$.}

Br. Zool. II. 390. iv. tab. 75 .

Br. Zool. II. 391. iv. tab. 75 .

BOTH thefe fpecies are fuppofed to breed in the Orknies, having been thot there in the Summer.

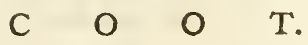

Br. Zool. 11. 392. iv. tab. 76 .

Br. Zool. II. 393 .

G $\quad R \quad E \quad B \quad E$.

Grebc, Br. Zool. II. 395. iv, tab. 17.'

IT'S fkin of great value for the making of 1 muffs and tippets. 


\section{$(37)$}

169 Eared.

$\stackrel{+}{170 \text { Dufky. }}$

171 Little.

172 Black.

chinned.

173 Great.

Lefier-crefled Grebe, Br. Zool. II. 396, iv, tab. 77. White and dufky Grebe, Br. Zool. II. 397, iv. :ab. 17.

Br. Zool. II. 398 .

Er. Spag-re-tois.

Br. Zool. iv. tab. 77 .

TRGER than the laft : upper part of the

1 body brown: chin marked with a large black fpot: neck ferruginous: the hind part mottled with durky feathers: belly alh-color'd and filvery.

\section{WEB-FOOTED.}

\section{A U $\mathrm{K}$.}

Br. Zool, II. 401. iv. tab. 18. Martin's St. Kilda 27. Mea cauley's 156 .

OOmetimes vifits St. Kilda's, and breeds $D$ there; not a regular migrant. Called there Gair-forvl, from Geyr-fugl, the name it is known by in Iceland, where they are common; from whence, or from Norroay, they may probably wander. 


\section{$\left(3^{8}\right)$}

${ }_{174}^{*}$ Razor-bill

175 Blackbilled.

i 75 Puffin.

177 Little.

I78Guillemot
Br. Zool. II. 403 , iv. tab. Ig.

Er. Coltraicise.

Br. Zool. II. 404 .

Br. Zool. II. 405 .

Er. Facbacb. Tom-noddy in the Orknies.

Er. Zool. II. 406. iv. tab. 19.

G U I L L $\quad$ E $\quad M \quad O \quad T$.

Br. Zool. II. 4 Io.

Er. Gearadb-breac, Eun-dubb-a'-cbrìlain.

THESE birds, and the razor-bills, are 1 taken in great numbers in the more diftant rocks of the Iebrides, for fake of their feathers, which are fold for fix or feven fhillings per ftone : their eggs are alfo a great article of food, attained with vaft hazard, either by climbing, or by being furpended by a rope from above, at a ftupendous height over a raging fea. This is a method conimon to molt of the maritime northern nations: Pontoppidan, in his hiftory of Norreay, and Claulon, in his account of the fame country, give amazing accounts of the manner in which the inhabitants obtain their ovarious food. In like way the natives of the Hebrides annually rifque their 


\section{( 39$)$}

their necks in fearch of provifion for therr children and families: whereas in feveral 'parts multitudes are reduced to the neceffity of watching the recefs of the tides to p.ck up a fcanty pittance of thell firh, their daily fuftenance at certain feafons; deftitute of ineal to give confiftence to their water, or a little milk for their perifhing babes!

$\stackrel{7}{17.9}$. Leffer.

$$
\text { Br. Zool. } 411 \text { iv. tab. } 20 .
$$

WIS fpecies, and the black-bill'd auk,
No. 175, appear in the Firth of Forth, in Oclober, in flocks innumerable, purfuing the fprats. Both kinds are called there Morots.

, so ${ }^{\dagger}$ Black. Br. Zool. II. 4I2. iv tab. 20.

Er. Callag. Tyfte in the Orknies.

181 Northern

Br. Zool. II. +13 .
Er. Bur-bbuacliaill.

THE herdimen of the fea, for the cre-

1 dulous believe that it never quits that elsment.

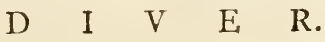

182 Imber. 


\section{(40)}

182 Imber.

183 Speckled.

+
184 Red-
throated.

$18 ;$ Blackthroated.

$*+$

$1 \stackrel{*}{8} 6$ Black.

$r_{7}^{*}$ Skua.

$188^{\dagger}$ Arctic.
Gefner's great Doucker, Wil. orn. 342. Kaii. Jyn. av. 125. Colymbus Immer. Lin $\int y j t .222$, Ember-goote of the Orknitss.

ARGER than a goofe: upper part of 1 the body and wings dufky : the feathers edged with cinereous : belly filvery grey.

Br. Zool. II. 414 .

Er. Fur-bbuacbaill.

Br. Zool. II. 4 I 5 . iv, tab. 21 .

Br. Zool. II. 415 iv. tab. 21.

$A$ Difinet fpecies from the former; but A fuppoled in the Br. Zool. to have been $m$. and $f$.

\section{G U L L.}

Br. Zool. II. 4 r6.

Br. Zool. II. 417 .

Br. Zool. II. 420. iv. tab, 22.

Er. Fägadair.

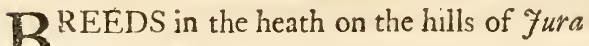

B and Rum: flies about like a lapwing when 

when difturbed, and foon alights. Comes to the Orknies in May; difappears in Auguft.

$1 \stackrel{*}{8}{ }^{\dagger}$ Herring.

Br. Z.0ol. II. 421. iv. $t a b .79$.

Igo Wagel.

Br. Zcol. II. 422. iv. $t a b .79$.

191 Winter.

Br. Zocl. II. 423 . iv. $t a b$. So.

$192+$ Common

Er. Zool. II. 424 , iv, tab. 23 .

$*+$

${ }_{193}^{*}$ Kittiwake

Tarrock, Br. Zool. II. 425. iv. tab. 23. Tour Scotlant.

COMMON on moft of the cliffs: affume when old the colors of the common gull: when young efteemed by many as a delicacy. Vide Tour in Scotland.

194 Black-

Br. Zool. II. 426.

headed.

$\stackrel{+}{195}$ Great.

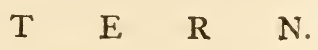

$*^{*} 6^{\dagger}$ Lefs.

Br. Zool. JI. 429. iv, tab. 81 .

Er. Steirneal. 


\section{$42)$ \\ $\begin{array}{lllllll}P & L & \mathrm{~T} & \mathrm{R} & \mathrm{E} & \mathrm{I} .\end{array}$}

197 Fulinar.

Br. Zool. II. 431. Martin's St. Kilila. 30. iv. tab. 82 :

FOUND in St. Kilda's only. 198 Shear-
water.

Ig ${ }^{*}$ Stormy.

200 Goorandir
Er. Zool. II. 433. Lyre of the Orkries Skrabe of the Faroe illes. Wil. orn. $43^{8}$.

"HE young highly efteemed as a deli\& cacy in the Orknies: are fometimes pickled: their feathers alfo much valued. Are taken in Auguft, on the rocks of Hoy and Eada: burrow in the earth, and lay one egg.

Br. Zool. II. 434. iv. tab. \$2.

REEDS under the loofe ftones on the

D little rocky inles called Macleod's table, \&c. off the N. end of Skie. Betrays its refidence by its twittering.

\section{E R G A N S E R.}

Br. Zool. II 436 . 


\section{$(43)$}

$=0 i^{+} \operatorname{Red}$ brealted.

202 Sinew.

203 Red = headed.

20* Wild fwan

$20 ;$ Tame fwan.

206 Grofe.

\author{
Er. Zcol. II. 437 . iv $t a b .8_{3}$. \\ Er. Sioltaiche.
}

$\mathrm{R}_{\text {REEDS among the loofe ftones } \mathrm{cn} \text { the }}$ B fea thore, and alfo on the fides of frefh. water lakes, far North.'

Br. Zool. II. 438 .

Er. Zool. II. $439 *$

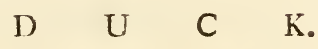

Br. Zool. II. $44 \mathrm{c}$.

Er. Eala.

VILD fwans vifit the Orknies in flocks in OEtober, and continue dur ng Winter: return North in the Spring, except a very few, which remain and breed in the littie inles of a freth water lough in Mainland.

Br. Zool. II. 44I.

Br. Zool. II. 447 . iv. $t a b .84$.

Er. (tame) Gea.th. (wild) Muir glbeadls.

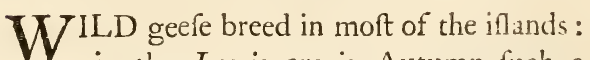
in the Lewis are in Autumn fuch a 


\section{( 44$)$}

peft to the corn, that the farmer is obliged to fet boys to guard it from their attacks. Wild geefe are fcarce known even to alight in the Orknies. Tame geefe and ducks very rare in the iflands.

207 Bernacic.

Br. Zool. II. $45 \mathrm{I}$.

${ }_{208}^{+}$Brent.

Br. Zool. II. 452 .

TS not known to breed in Orkney.

${ }_{20}^{*}{ }^{t}$ Eider.

Br. Zool. II. 454. Tour Scot. tab. I.

Er. Lacba lochlannach. Dunter goofe in the Orknies.

PREEDS in Collonsa, Barra, in the Flan1 1) $n$, and other inles; alfo in Incb-colm in the Firtb of Forth. The down neglected thro' ignorance of the value: the neft might be robbed twice of the eggs and down, and the bird will repair it's lofs each time; but they muft be fpared the third. We procure the down from Iceland and Norway, and pay a confiderable price to foreigners for $i t$.

sro Velvet. Br. Zool. II. 456 . iv. tab. 85 .

211 Scoter.

Br. Zool. II. 457 .

2is Tufted. 
$212^{+}$Tufted.

213 Scaup.

2I4 GoldenEye.

$+$

215 Shieldrake

$216{ }^{\dagger}$ Mallard.

217 Shoveler.

$+$ Pintail.

219 Swallowtail.

220 Pochard.

221 Ferrugincus.
Br. Zool. II. $45^{8}$.

$F^{\text {Requents the Orknies in Winter during a }}$ N. wind.

Br. Zool. II. 459 .

Br. Zool. II. ${ }_{460}$.

Br. Zool. II. $46 \mathrm{r}$.

Er. crà-gbeallh. Sly goofe in the Orknies:

Br. Zool. II. 462. iv. tab. 24 .

Er. Lacba-chinn-uaine.

7 AME ducks rare in the inlands.

Br. Zool. II. 466.

Br. Zool. II. 468.

Br. Zool. II. 469 . iv. 86.

Br. Zool. II. 470 .

Br. Zool. II. 471 . 


\section{$(46)$}

222 Gadivall.

Er. Zool. II. 473 .

223 Wigeon.

Br. Zool. II. 472 .

${ }_{224}^{+}$Garganey

Br. Zool. II. 474. iv. tab. 87 .

$\stackrel{+}{+}$ Teal.

Br. Zool. II. 475 .

Er. cran-lacha.

226 Common.

\section{O R V O R A N T.}

Br. Zool. II. 476 .

Er. Ballaire-boan.

227 Shrg.

Br. Zool. II. 478. iv. tab. 25 .

Er. Sgarbb.

$2{ }_{28}^{*}$ Gannet.

Br. Zool. II. 479. Tour Scotl.tab. viii.

Er. Sùlaire, ambjain.

RREEDS on the Bafs inland in the Firth 13 of Forth, the craig of Ailfa, in that of Clyde, on the rocks about St. Kilda, and a rock called the Stack, near Soulifkir, ten leagues W. of Hoy. 


\section{CLASS II. REPTILES.}

$\begin{array}{llllllll}T & \mathrm{O} & \mathrm{R} & \mathrm{T} & \mathrm{O} & \mathrm{I} & \mathrm{S} & \mathrm{E} .\end{array}$

Have been informed that one had been 1 taken near the ine of Col, but fuppore it to have been a tortoife that had efcaped out of fome Weft Indian wreck.

$\stackrel{+}{+29}$ Comman.
F
R
O G.

Br. Zool. II. 3.

Er. Loifkain.

\section{NCNE in the Long-Ifland,}

${ }_{230}^{+}$Toad.

Br. Zcol. 7.

Er. mylungain.

$23 i$ Great.

Nhabits the woods near Lough-Ranfa, in Arron: is double the fize of the common frog: body fquare: belly great: legs fhor: : four toes on the fore feet; four and a thumb to the hind feet ; the fecond outmort toe the longeft: color above a dirty olive, marked with great black warty fpots, the head alone plain : color beneath whitifh: leaped nowly. 


\section{$(48)$}

\section{$\begin{array}{llllllll}\text { L } & \text { I } & \text { Z } & \text { A } & \text { R } & \text { D. }\end{array}$}

$+$

232 Scaly.

233 Brown.

Br. Zool. III. I3.

Er. Jac-lu-acbu-racb.

Br. Zool. III. 16.

Er. Duirk-luacbair, i. e. obferver of the rufhes.

\section{$\begin{array}{llllllll}S & E & R & P & E & N & T\end{array}$}

Er. Zool. III. 17 .

Er.

THE black viper is very common in the 2. highlands : numbers of vipers in Ilay, Fure, and skie. In fome of the ines it is fill believed that they fting with their tongues, and do not convey the poifon with the teeth : that the venom dropt on a fword will caufe it to hifs like water on hot iron; and that a poultice of human ordure is a fovereign remedy for the bite. No fpecies of ferpent in Lewis, or any part of the long inand.

Anguis Eryx. Lin. Jyf. 392. Tour Scotland, Appendix.

ENGTH fifteen inches: tongue broad Wo and forked : notrils fmall, round and placed near the tip of the nofe : eyes lodged 


\section{( 49 )}

in oblong figures above the angles of the mouth: had no fcuta, but was entirely covered with fcales : back and fides of a greyin brown, with three dufky lines, one extending from the head to the tail; the others, which were broader, reached the whole length of the fides: the belly bluinh leadcolor, fpotted with white. Difcovered by the late Doctor David Skene, near Aberdeen.

Br. Zool. III. 25. 


\section{$(50)$ \\ C L A S S IV. F I S H. \\ Div. I. C E T A C E O U S. \\ W $\mathrm{H}$ A L E.}

${ }_{237}^{+}$Common

$23^{8}$ Pikeheaded.

239 Fin.

240 Roundlipped.

+
241 Great-
headed.

242 Roundheaded.

243 High-
Br. Zool. III. 35. Sib. Pbalain. 65.

Br. Zool. III. 40. ‘ib. Pbalain. 68.

Br. Zool. III. 4 I.

Br. Zool. III. 42. Sib. Pbalain. 78.

C A $\quad$ C

Br. Zool. 46. Sib. Phalain. 33.

Br. Zool. III. 47. Sib. Phalain. 24

Br. Zool. III. 47. Sib. Pbalain. 43.

GEEN in Locb-Brakadale, in skie. Excepting this and the porpeffe, the other fpecies are inferted on the authority of Sir Robert Sibbald*.

* Vide the new edition of his hiftory of whales, printed for Benjamin Wbite, bookfcller, Fleet-fircet.

DOLPHIN. 


\title{
(51)
}

${ }_{244}^{*}+$ Porpeffe.

\section{$\begin{array}{lllllll}D & \mathrm{O} & \mathrm{L} & \mathrm{P} & \mathrm{H} & \mathrm{I} & \mathrm{N} \\ \mathrm{N}\end{array}$}

\author{
Br. Zool. 52. S.
}

$\mathrm{I}$ great droves in every part of the 1 Northern feas.

245 Grampus Br. Zool. III. 54. Sib. Phalain. 18.

\section{Div. II. CARTILA GINOUS.}

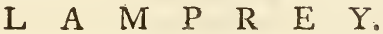

246 Lamprey

Br. Zool. III. $5^{8 . ~ i v . ~} t a b .88$.

Er. Creaboule.

FOUND from the river $E f k$, in $E / k$ dale, to the water of Hemsdale, in Sutberland. Detefted by highlanciers.

$\stackrel{+}{247 \text { Skate. }}$

+
248 Thorn-
back.

249 Fuller.

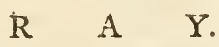

Er. Zool. III. 62.

Er. Skeait.

Br. Zool. III. 69. iv. tab. 27, 28.

Br. Zool. III. 66.

7 AKEN in little Locb-Broom.

$$
\text { E } 2
$$

$S H A R K$. 


\title{
S H A $\mathrm{R}$ K.
}

\author{
Br. Zool. III. 77.
}

Er. Doulag, Cüù.

FOUND in great multitudes on the Scotti $/$ s coafts; and when dried a great article of food with the common people. Called in Sky the Blind-bive, and is fuppofed to be a great reftorative.

THE greateft of the genus; fometimes 1 above 36 feet long: the length of one $I$ found dead near Locb-Ranfa, in Arran, was $27 \mathrm{f} .4$, firft dorfal fin 3 , fecond I, pectoral 4 , ventral 2 feet long, upper lobe of the tail 5 , lower 3 .

They appear in the Firth of Clyde, and among the Hebrides, about the month of Fune, in fmall droves of feven or eight, but oftner in pairs; and continue in thofe feas 'tull the latter end of fuly, and then difappear : they fwim very deliberately, with the two dorfal fins above water: are very tame, and fearlefs of mankind: will permit a boat to follow them without accelerating their motion, 'till it comes almoft within contact, 
when a harpooneer ftrikes his weapon into the fin as near to the gills as poffible; but they are often fo infenfible as not to move 'till the united ftrength of two men have furced the harpoon deeper: as foon as they perceive themfelves wounded, they fling up their tail and plunge headlong to the bottom; and frequently coil the rope round them in their agonies, attempting to direngage themfelves from the harpoon by rolling on the ground, for it is often found greatly bent : as foon as they difcover their efforts are vain, they fwim away with amazing rapidity, and with fuch violence that a vefiel of 70 tons has been towed by them againft a frefh gale: they fometimes run off with 200 fathoms of line and two harpoons in them, and will find employ to the fifhers for twelve and fometimes twenty-10ur hours before they are fubdued : when killed they are either hawled on Thore, or if at a diftance to the veffel's fide: the liver (the only ufeful part) is taken out, and melted into oil, in kettles providec for that purpofe: a large fin will yield eight barrels of oil, and two of worthlefs fediment. The commiffioners of the forfeited eftates were at confiderable expence in their encouragement of this fpecies of fifhery; but the perfon they confided in moft Thamefully abufed their goodnefs; fo now it is attempted only by private adventurers. 


\section{( 54$)$}

252 Blie.

Br. Zosl. III. 84 .

A AKEN near Aberdeen.

$+$

2;3 Leffer-

ipotied.

$2 ; 4$ Lump.

255 Jura.

$$
P \quad I \quad P \quad E \text {. }
$$

Br. Zool. IIt. 106. 


\section{Div. III. B O N Y F I S H.}

A $P$ O D A $\mathrm{L}$.

E E L.

257 Common.

Er. Zool. III. iii.

258 Conger. Br. Zool. III. II5.

A Confiderable trade is carried on from A Falmouth with the Spaniards at Barcelona in dried congers: perhaps the fame might be done from fome of the Hebrides.

\section{W O L F.}

$+$

259 Ravenous
Br. Zool. III. I1 1 g. tab. 7 .

CALLED in Edinburgh cat-fin, and efteemed (what it really is) a very delicate fifh.

\section{A U N C E.}

Br. Zool. III. 123 . 


\section{J U G U L L A R, \\ C O D.}

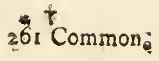

Br. Zool. III. 137 .

A Bundant in all the feas, but the firheries A neglected or mifmanaged.

$\stackrel{+}{262}$ Tork.

Br. Zool. III. 143 .

${ }_{26}^{*}{ }^{*}{ }^{\dagger}$ IIIadock.

Br. Zool. III. 144\%

${ }_{25}^{*}{ }_{4}^{+}$Coal.

Br. Zool. IIII. 152. iv. tab. 32 .

${ }_{20}^{*}{ }_{5}$ Pullack.

Br. Zool. III. 154 .

266 Whiting.

Br. Zool IIII. $155^{\circ}$

${ }_{267}^{*}$ Ling.

Br. Zool. III. 160.

GOOD finheries of ling about the ine of Lewis; the fame might be eftablifh'd about the other ines; whofe inhabitants are too poor to undertake any thing without affiftance. I met with multitudes who were reduced to the diftrefs mentioned p. $3 \mathrm{~S}$, for want of a few common firh-hooks: I partook 


\section{( 57 )}

partook of their unhappiness by my inability to fupply their wants; for I imagined mylelf on a voyage to places where neither riches nor poverty had reached, and came provided with gew-gaws as prefents to the good people : but alas! in moft places a peck of oatmeal, or a few poor fifh-hooks would have been more acceptable than the gayeft productions of Birmingbam or spittle-fieids.

$\stackrel{2}{t}^{t}$ Fivebearded.

\section{Smooth.}

$270^{*}{ }^{+}$Spotted.

27i Vivipa-
rous.

${ }_{372}^{*} \dagger^{\dagger}$ Black.

273 River. Brown Whiftle-fifh, Br. Zonl. III. 65. iv. tab. 33.
Fifhick in the Orknips.

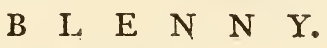

Br. Zool. III. 169: iv. tab. 34 .

$B r$. Zool. III. 171. iv. $t a b .96$.

Br. Zool. III. 172 .

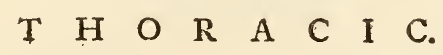

G O B $\quad$.

Br. Zool. III. 174 .

\section{B U L L - H E A D.}

Br. Zool. III. 177 . 


\section{$\left(5^{8}\right)$}

274 Armed.

Br. Zool. III. 178 .

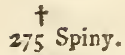

Br. Zool. III. 179. jv. $t a b .35$.

\section{O R E E.}

275 Doree.

Er. Zool. III. 181. iv. tab. 73 .

PRofeffor Oglevie, of Old Aberdeen, in1 formed me it had been taken near that place.

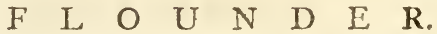

$\stackrel{+}{ }{ }_{277}$ Holibut.

Br. Zool. III. 185 .

278 Plaife.

Br. Zool. III. : 8;.

279 Fluke.

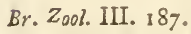

2So Dab.

Br. Zool. III. 188.

28s Smeardab.

Br. Zool. III. 189 , iv. tab. 46 .

282 Sole.

Br. Zool. III. 190. 


\section{$(59)$}

${ }_{2} 8_{3}$ 'Turbot.

Br. Zool. IlI. 193.

$$
\text { G I L T H E A D. }
$$

$288_{4}^{*}$ Gil head.

Br. Zool. III. 197. iv. tab. 9r.

$T^{H E}$ Braife of the Scois.

W $R$ A $S$ S E.

$28 ;$ Common

Br. Zool. III. 223 .

$2 \$ 6$ Trimacu-

lated.

Br. Zool. III. 206. iv, tab. 37 .

P E R C H.

288 Common

Br. Zool. III. 2 Ix.

S T I C K L E B A C K.

Br. Zoot. III. 220. iv. tab. 42 .

$\begin{array}{lllllll}M & A & C & K & R & L\end{array}$

$29{ }^{*} \stackrel{+}{\text { Common }}$

Br. Zool. III. $22 x$. iv. tab. 97 •

A PPEARS not tiil Auguf in the Northern 1 parts of Scotland, and then fimall and Jean. 
29l Tunny.

292 Grey.

293 Bearded.

294 Common

2;5 Grey.
Br. Zool. III. 223. iv. tab. 43. Tour Scotlard.

\section{$G \cup R A$ A $R$.}

Br. Zool. III. 331 . iv. $t a b .38$.

\section{A B D O M I N A L. \\ I $\mathrm{O} \quad \mathrm{C}$ H}

Br. Zool. III. 237. iv. tab. 93 .

$S$ A $L \quad M O N$.

Br. Zocl. III. 239 .

COMMON in all parts during the feafon: but rare in the Orknies.

Br. Zool. III, 248. Phinoc. Tour Scotland.

A Grey fifh, of the falmon kind, with a A back fpotted with black, and about a foot long, comes up feveral of the rivers in Scotiand in vaft hoals during the month of Auguft: they return to the fea in November; are called Pbinccs; and are fuppofed by the fifhermen to be the young of a great grey trout weighing 30 pounds. 


\section{(61)}

296 Bull.

Br. Zool. 1II. 249.

* t Trout.

Br. Zool. III. 250. iv. tab. 93 •

$\mathrm{R}_{\text {Emarkably fine and large in moft of the }}$ $\mathrm{R}_{\text {lakes. }}$

$\stackrel{+}{297}$ Samlet.

$+$

298 Charr.

299 Guiniad.

300 River.

301 Saury.
Br. Zool. III. 253 .

Br. Zool. III. 256. iv. tab. 94 .

Br. Zool. III. 267 .

$\mathrm{F}^{\text {OUND in Loch-Mabon; called in thofe }}$ parts the Vendace, and Fuvangis; and in

Locb-Lomond, where it is called the Poan.

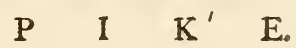

Br. Zool. III. 270. iv. tali. 95 .

Tour Scotland, App. tab, 17 ,

GRET numbers were flung on thore on $\mathbf{r}$ the fands of Leith, after a great ftorm, November $177^{\circ}$ 
$\begin{array}{lllllllll}A & R & G & E & N & T & I & N & E\end{array}$

${ }_{302}^{*} \mathrm{Pca} \cdot \mathrm{ly}$.

Br. Zool. III. 276. iv. $t a b .45$.

\section{U L L E T.}

$30_{3}$ Grey.

Br. Zool. III. 278. iv. tab. 94 .

\section{$\begin{array}{lllllll}H & E & R & R & I & N & G\end{array}$}

304 Northern

Br. Zool. III. 284 .

305 Sprat.

Br. Zool. III. 294.

306 Shad.

Br. Zool. III. 296.

T Have no certain proof of the thad having

1 been taken in Scotland; but it's fry, the white bait, appears near Aberdeen.

\section{A $\mathrm{R}$ P.}

307 Pond.

Br. Zool. III. 300 .

WILL live but do not breed in the ponds of North-Britain. 
3os Chub.

309 Bream.

310 Minow.
Br. Zool. III. 313 .

$\mathrm{I}^{\mathrm{N}}$ the Annan。

Br. Zool. III. 309 .

FOUND in Locb-Maban.

Br. Zool. III. 3 I. 


\section{(64)}

\section{FRAGMENTS of CLASSES.}

\section{CRUSTACEOUS ANIMALS.}

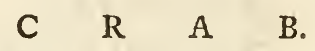

* With a fquare body.

3il Blackclawed.

312 Common

313 Velvet.
Cancer pagurus, Lin. Syf? 1044.

Cancer mænas, Lin. fyj? 1043.

$\mathrm{H}^{\text {RONT quinque-dentated, fmooth : claws }}$ covered with minute tubercles; body with a velvet pile: hind legs pinnated. Skie.

$W^{\text {ITH the upper fhell lamellated: front }}$ quinque-dentated and ferrated : two fpines on the claws: hind legs pinnated. Skie.

3t5 Minute.

Cancer minutus, Lin. fyjt. 1040.

* With heart-rhaped body。

Tour in Scotland, tab. xviii. 1047.

Cancer horidus, Lin. Jjif.

NEAR Dunbar and Aberdeen. 


\section{$(65)$}

$3^{1} 7$ Great clawed.

A Small fpecies : claws very large and $A$ hairy : antennæ very long, when flung behind reaching far beyond the back. Skie.

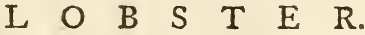

318 Common

Cancer Gammarus, Lin. fyf. 1050.

GREAT numbers are fent from the Eaftern coafts of Scotlond to fupply the London markets.

319 Norway.

320 Wrinkled

321 Clawlers.
Cancer Norvegicus. Lim. Sy. 1053.

Cancer Strigofus. Lin. Jyßf. 1052.

$\mathrm{I}^{\mathrm{N}}$ the found of Ilay.

Cancer Homarus. Lin. Jyf. 1053.

Marine infects obferved in different places.

Phalangium groffipes. Lin. fy 1027 .

$I^{N}$ the late Doctor Skene's cabinet.

Phalangium Balænarum. The whale-loufe, Lin. Jyg. 1028 , ibid.

$\mathrm{B}^{\mathrm{OTH}}$ found near Aberdeen. 


\section{(66)}

Onifcus marinus, Lin. $\int_{j f} .1060$.

W $\quad \mathrm{O} \quad \mathrm{R} \quad \mathrm{M} \quad \mathrm{S}$.

$\begin{array}{lllllll}A & C & T & Y & N & I & A\end{array}$

Hydra difciftora. Pb. Tran. vol. 4, 18, 83, tab. \&, fig. 5 .

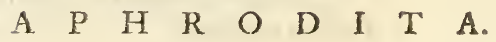

Aph. fquammata, Lin. Sig. 1084 .

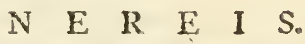

N. Pelagica. Lin. Jyf. 1086.

N. cxrulea. Lin. Jjh. 1086.

\section{$M$ E D U S A.}

M. veiella, Lin. Jys. $10 \mathrm{~g} 8$.

A STERIAS. STAR.

A. Pectinata Linckii xxxvii. No. 64 . Aculeata xxxvii. No. 67 . Rubens xxxvi. No. 62 . Dentata $x v$. No. 18 . Ophitira ii. No. 4 . 
$P \quad L \quad A \quad N \quad T \quad S$. 


\section{MONA N D R I}

M O N O G Y N I A.

SALICORNIA. Calyx I-phyllus. Cor. o.

HIP PURIS. Cal. o. Cor.o.

D I $\quad G \quad Y \quad N \quad I \quad A$

CALLITRICHE. Cal. o. Cor. 2-petala.

Capfula 2-locularis. 
MONANDRIA MONOGYNIA.

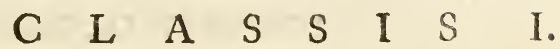 \\ $M O N A N D R$ I A \\ $\begin{array}{llllllllll}M & \mathrm{O} & \mathrm{N} & \mathrm{O} & \mathrm{G} & \mathrm{Y} & \mathrm{N} & \mathrm{I} & \mathrm{A}\end{array}$}

SALICORNIA Lin. Gen. Plant. 10.

Calyx ventriculofus, integer. Petala 0. Semen unicum.

berbacea 1. SALICORNIA herbacea patula, articulis apice compreffis emarginato-bifidis. Lin. Spec. Plant, pag. 5. (Oed. Dan. t. 303. oplimis.)

Marh fampire, jointed glaffwort, or falt-wort Anglis.

Found on the fea coafts, as at Blacknefs-Caftle, and Aberlady Bay. Dr. Parfons. ๑. VIII. IX.

In England the tender hoots of this plant are ufed as a pickle, and are fometimes boil'd for the table.

There is a variety of it which puts on a woody appearance, and is often perennial, which fome have diftinguifh'd as a fpecies.

Several perfons have obferv'd the flowers of this genus to have two Atamina. It may therefore belong perhaps more properly to the next clafs of Diandria. 


\section{HIPPURIS. Lin. Gen. pl. I1.}

Cal. o. Petala. o. Stigma fimplex. Sem. 1.

vulgaris 1. HIPPURIS. Lin. Sp. Pl. 6. (Oed. Dan.t. 87, opt.) mare's tail. Anglis.

In marnes and ftagnant waters, as in the ditches near Edinburgh: I found it alfo in Ilay, by the fides of the Locbs in deep muddy places. 4. VI.

\section{I G Y N I A.}

CALLITRICHE. Lin. Gen. Pl. 13.

Cal. o. Petala 2. Sem. I ovale, nudum.

werna. 1. C. foliis fuperioribus ovalibus, floribus androgynes. Lin. Sp. Pl. 6. (Oed. Dan. t. 129, opt.)

Vernal ftar-headed chickweed. Anglis.

Found in ditches and ftill waters frequently. $\odot . V$.

autumnalis

2.

C. foliis omnibus linearibus apice bifidis, floribus hermaphroditis. Lin. Sp. Pl. 6. (Loes Fl. Prufs. 140. $t$. 38. Pet. Herb. brit. t. 6. f. 4.) Autumnal ftar-headed chickweed. Anglis. Found in the fame kind of places as the preceding. ๑. IX. 
D I $A$ N $D$ D $R$ I $A$.

C L A $S$ S I S II.

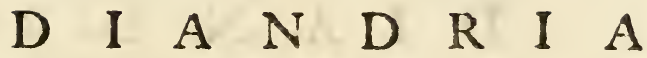

\section{MO N O G Y N I A.}

* Flores inferi, monopetali, regulares. LIGUSTRUM. Cor. 4-fida. Bacca 4-fperma. ** Flores inferi, monopetali, irregulares. Fruilus capfularis.

VERONICA. Cor. 4-partito limbo; lacinia inferiore anguftiore.

PINGUICULA. Cor. ringens, calcarata. Cal. 5 -fidus.

UTRICULARIA. Cor. ringens, calcarata. Cal.

2 phyllus.

*** Flores inferi, monopetali, irregulores. Frufus gymnoppermi.

VERBENA. Cor. lubæqualis. Cal. lacinia fuprema breviore.

LYCOPUS. Cor. fubæqualis. Stam. diftantia. SALVIA. Cor. ringens. Filamenta tranverfè pedi. culata.

$$
\text { **** Flores superi. }
$$

CIRCOEA. Cal. 2 phyllus. Cor. 2-petala obcordata.

$$
\text { * Salicornia. }
$$

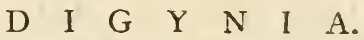

ANTHOXANTHUM. Cal. Gluma 1-fora, oblongo. Cor. Gluma ariftata. 
C $\quad L \quad A \quad S \quad S \quad I \quad S \quad I I$.

D I A N $\quad \mathrm{D} \quad \mathrm{R} \quad \mathrm{I} A$

\section{O N O G Y N I A.}

LIGUSTRUM. Lin. Gen. 18 .

Cor. 4-fida. Bacca tetrafperma.

vulgare I. LIGUSTRUM. Lin. Sp. Pl. 10. (Mill. ic.t. 162) fig. 2.

Privet. Anglis.

In the hedges about Hamilton, but is not common in Scotland. 5 . VII.

\section{VERONICA. Lin. Gen. 25.}

Cor. Limbo 4 partito; lacinia infima anguftiore. Cappula bilocularis.

$$
\text { * Spicate. }
$$

oficinalis I. VERONICA. fpicis lateralibus pedunculatis, foliis oppofitis, caule procumbente. Lin. Sp. Pl. I4. (Oed. Dan. t. 248)

Male Speedwell. Anglis.

Common in heaths and dry woods. 4 . VII.

** Corymbofo-racemolar.

sipina 2. V. corymbo terminali, foliis oppofitis, calycibus hifpidis. Lin. Sp. Pl. 15. (Fl. Lapp. t. 9. f. 4. Hall. Strip Helvet. Pag. 235.t. 15.f. 2. Oed. Dan. t. 16.)

Alpine Speedwell. Anglis.

It is found on the mountains of Badenoch, and Locbaber. 
Obr. The ftalk is about three inches high, unbranch'd, and flightly hairy : the leaves are oval, a little hairy, and fometimes finooth, farcely crenated on the edges : eight or ten fmall biue flowers grow in a hort fpike at th.e top of the ftalk, mix'd with lanceolate ftipulæ.

Serpyllifolia VERONICA racemo terminali fubfpicato, foliis 3. ovatis glabris crenatis. Lin. Sp. Pl. I 5. (Ger. Emac. pag. 627.f. 2. Oed. Dan. 492)

Little Smooth Speedwell, or Paul's-Betony. Anglis. Frequent in paftures, and by way-fides. 4 . VI.

Obr. The ftalk creeps at firft, but at flowering grows erect: the flowers arife from the Alce of the leaves, on fhort fooftalks, having the three upper fegments of the Corolla ftreak'd with longitudinal lines: the middle fegment of thefe three is generally blue, the two fide ones of a paler colour, and the lowermolt wibite.

beccabunga V. racemis lateralibus, foliis ovatis planis, caule 4. repente. Lin. Sp. Pl. 16. (Ger. Emac. p. 620, f. I. Oed. Dan. $t$ 51 1. opt.)

Common Brooklime. Anglis.

Frequent in ditches and rivulets. 24. VII.

Obf. It is efteem'd an antifcorbutic; and is eaten by fome in the Spring as a fallet, but is more bitter and not fo agreeable to the palate as Watercreffes. The flowers are of a fine blue, and the leaves are fmooth, thick, and fucculent.

enagallis V. racemis lateralibus, foliis lanceolatis ferratis, aquatica 5. caule 
caule erecto. Lin. Sp. Pl. 16. (Ger. Emac. p. 620, f. 2, Pet. Herb. Bris. T. 5 I, f. 12)

Long-leav'd Brooklime. Anglis.

It grows in like places with the preceding. 4 . VIII. Obi. The fowers are fmaller than the veronica Beccabunga, and are of a pale fien colour: the three upper fegments ftreak'd with red veins.

frutellaia 6 VERONICA racemis lateralibus alternis; pedi. cellis pendulis, foliis linearibus integerrimis. Lin. Syft. Nat. 58, Sp. Pl. 16. (Moris Hift. Ox. Se.?. 3, t. 24, f. 27, Oed. Dan.t. 209. opt)

Narrow-leav'd Water Speedwell. Anglis.

Found in marhes and on the fides of lakes. 24. VII. Obr. The leaves are fometimes nightly ferrated, and the flowers generally of a pale colour, almoft white, but few in number, and fupported by nender weak footitalks.

moniana 7. V. racemis lateralibus paucifloris, calycibus hirfutis, foliis ovatis rugofis crenatis petiolatis, caule debili. Lin. Sp. Pl. 17. (Pet. Her. Br. t. 51, f. 4, Moris. Hift. Ox. Sect. 3, t. 23, f. 15 , melior.)

Stalked Speedwell. Anglis.

Grows in moift fhady woods, but not common : in the woods at Dunglafs, near the river. Dr Parfons. 4. VI.

Obf. The leaves are very hairy and reddin underneath : the flowers are of a pale blue, their fegments edg'd with white.

chamecixys $\mathrm{V}$. racemis lateralibus, foliis ovatis feffil bus ru8. gofis dentatis, caule debili, bifariam pilofo. Lin. 
Lin. Mant. 317, Sp. Pl. 1\%. (Ger. Enr. 657, f. 3, Hift. Ox. Sect. 3, T. $23, f .12$, Oed. Dan. $t$. 448 , opt.)

Wild Germander. Anglis.

Found very common under hedges and in meadows. 4. V. and VI.

Obf. The leaves are hairy, and the flowers of an elegant bright blue, Atreak'd with veins of a deeper color. It is a great ornament to the hedges.

\section{*** Pedunculis unifloris.}

tgreftis 9. VERONICA floribus folitariis, foliis cordatis incifis pedunculo brevioribus. Lin. Sp. $P_{i}$ i 8 . (Ger. Em. 6ı6.f. I. Oed. Dan. t. 449. opt.)

Germander-Speedwell, or Chickweed. Anglis.

A common weed. $\odot$. V.

Obf. It has branched trailing ftalks, with leaves growing oppofite at the bafe, but alternate at the top: the flowers are very fmall, generally blue, and grow fingly on long footitalks.

arvenfis 10. V. foribus folitariis, foliis cordatis incifis pedunculo longioribus. Lin. Sp. Pl. 18. (Ger. Ent. Pag. 6I3.f. 7. Mor. Hift. Ox. Sect. 3. t. 24.f. 21, Oed. Dan. t. 515.) Wall-Speedwell. Anglis.

It is common upon old walls. $\odot . V$.

Obf. The flowers of this are generally of a pale color, almoft white, growing on very fhort or no foo:ftalks, which diftinguifhes it fufficiently from the preceding: 
bederifolie V. floribus folitaris, foliis cordatis planis quinque1 I. lobis. Lin. Sp. Pl. 19. (Ger. Em.6r6.f. 3. Mor. Hift. Ox. Sec. 3. t. 24. f. 20. Oed. Dan. t. 428. opt.)

Ivy-leav'd Speedwell, or Small-Henbit. Anglis. In corn fields and gardens frequent. $\odot . V$.

Obf. The ftalk is branched and trailing: the leaves are rounded, and grow in pairs at the bafe, but are angular and alternate under the flowers: the footftalks of the flowers are long, hairy, and bend downwards: the fegments of the calyx are hairy, and comprefs the capfule: the flowers are of a pale blue, or white, ftreak'd with veins of a deeper blue or red color.

\section{PINGUICULA. Lin. Gen. 30 .}

Cor. ringens, calcarata. Cal. bilabiatus, 5-fidus. Caps. unilocularis.

wharis 1. PINGUICULA nectario cylindraceo longitudine Petali. Lin. Sp. Pl. 25. (Ger. Em. 788. f. 2. Mor. Hift. Ox. Sect. 5. t. 7.f. 13. Oed. Dan. t. 93. optima.)

Common Butterwort.- Anglis. Brogan-na-cu'aig. Gaulis.

This grows very common in moift grounds, and on the fides of the mountains. 24. VI.

The flower is of a deep violet color, hairy within. The inhabitants of Lapland, and the North of Sweden, give to milk the confiftence of cream, by pouring it warm from the cow upon the leaves 
leaves of this plant, and then inftantly ftraining it, and laying it afide for two or three days 'till it acquires a degree of acidity. This milk they are extremely fond of; and when once made they need not repeat the ufe of the leaves as above, for a fpoonful, or lefs of it, will turn another quantity of warm milk, and make it like the firft, and fo on as often as they pleafe to renew their food.

villofa 2. P. fcapo villofo. Lin.Sp.pl.25. (Fl. Lap.t. 12.f. 2. et. Vid. Fiz.nof.)

Little fleth-color'd Butterwort. Anglis.

I found it in Stratb-Swardle, in the ine of Skie, in a bog juft by Mr. M'Kennon's, of Coryattachan, and on the fide of a mountain there call'd Benna-Caillich. 4. VII.

Obf. The leaves are reticulated with red veins: the ftalk is nightly hairy, and about two inches high : the flower is flefh-color'd; and the whole plant, in all its parts, five times fmaller than the preceding.

\section{UTRICULARIA. Lin. Gen. 3 I.}

Cor. ringens, calcarata. Cal. 2-phyllus, æqualis. Caps. unilacularis.

ขulgaris 1. UTRICULARIA nectario conico, fcapo pattciforo. Lin. Sp. pl. 26. (Petiver.Her. Brit. T. $3^{6 . f}$. I 1. Oed. Dan. t. I $38.0 p t$.)

Common Hooded Milfoil. Anglis.

In deep ditches and ftagnant waters, as in GuillonLoch. Dr. Parfons. 4, VII. 


\section{DIANDRIA MONOGYNIA.}

Obr. The leaves are capillary, branched, and immers'd under water, having numerous tranfparent veficles adhering to them: the ftalk is erect, dettitute of leaves above water, and bears a loofe fpike of five or fix flowers: the calyx is murry colour'd, the flower yellow, the lower lip vein'd with orange, and gibbous.

minor 2. UTRICULARIA nectario carinato. Lin. $S p$. pl. 26. (Pluk. Alm. t. 99. f. 6. Petiv. Herb. Brit. T. 36.f. 12. Oed. Dan. Tab. 128. opt.)

Leffer Hooded Milfoil. Anglis.

Found in like places with the preceding, but more rarely: I gathered it in a bog at Coryattachan, in Skie, together with the Pinguicula villosa. 4. VII.

Obf. This has the habit of the preceding, but is, in all its parts, much lefs: the flower is of a paler yellow, the fpur hardly diftinguifhable, and the lower lip plane, not gibbous.

\section{VERBENA Lin. Gen. 32.}

Cor. infundibuliformis, fubæqualis, curva.

Calcys unico dente truncato. Semina 2. 5. 4. nuda. (Stam. 2. s. 4.)

officinalis 1. VERBENA tetrandra, fpicis filiformibus paniculatis, foliis multifido-laciniatis, caule folitario. Lin. Sp. pl. 29. (Ger. Emac. 718.f. I. Tournf. Inft. t. 94.)

Vervain. Anglis. 
DIANDRIA MONOGINIA.

By road fides near towns and villages. $\odot$. VIII. Without the gates of Innerkeitbing. Dr. Parfons.

\section{LYCOPUS. Lin. Gen. 33 .}

Cor. 4-fida, lacinia unica emarginata. Stamina diftantia. Semina 4, retufa.

suropaus I LYCOPUS foliis finuato ferratis. Lin. sp. pl. 30. (Ger. Emac. 700.f. 1. Petiv. Herb. Br. t. 32.f. 5.)

Water Horehound. Anglis.

On the banks of rivers and ditches. 24. VII.

Obr. This plant has the habit of thofe of the Didynomia clafs, but the flowers have only two ftamina: they grow in thick whirls around the ftalk, fmall and white, and hairy within: the Jower fegment is mark'd with red dots.

\section{SALVIA Lin. Gen. pl. 39.}

Cor. inæqualis. Filamenta tranfverfe pedicello affixa.

verbenaca I SALVIA foliis ferratis finuatis læviufculis, corollis

calyce anguftioribus. Sp.pl. 35. (Ger. Emac. 771 . f. 1. Cluf. Hift. xxxi. fig. ad finiftram.)

Common Wild Clary. Anglis.

Under Salifoury crags, and on a bank at the enrance into Kirkcaldy, from Dyfart. 24. VI.

\section{CIRCÆA. Lin. Gen. 24.}

for dipetala. Cal. diphyllus, fuperus. Sesm. I. biloculare. 
lutetiana 1. CIRCÆA caule erecto, racemis pluribus, folins ovatis. Syft. Nat. 56. (Oed. Dan. t. 210. Ger. Emac. 351. Park. 351.)

Enchanters Nighthade. Anglis.

In woods and thady places. 2. VII.

The ftalk is erect, a foot and a half high, and has lateral branches: the leaves are fightly hairy on the margin, and are either intire, undulated, or a little ferrated : the footftalks of the flowers are flightly hairy, the calyx the fame, of a greenifh colour, a little ting'd with red, and of a much thicker fubftance than the petals, and a different color.

alpine I. CIRCEA caule proftrato, racemo unico foliis cordatis. Syft. Nat. 56. (Oed. Dan. t. 256. Moris. Hift. Ox. SeEt. 5. t. 34. fg. 2. ad imum.)

Alpine Enchanters Nighthade. Anglis.

At the foot of the mountains about Locb-Broom, in Ross-jbire. 24. VII.

This is very nearly related to the preceding, but differs in the following refpects: The ftalk is about five or fix inches high, feldom branching, and reclines on the ground towards the bafe: the leaves are quite fmooth, and deeply cut or ferrated on the edges : the footitalks of the flowers are fmooth, the calyx the fame, of a more delicate texture than the preceding, and ting'd with nearly the fame red colour as the petals. 


\section{$D$ I $G \quad Y \quad N$ I $A$.}

ANTHOXANTHUM. Lin. Gen. 42 :

Cal. Gluma bivalvis, unifora. Cor. Gluma bivalvis, acuminata. Sem. I.

odoratum I ANTHOXANTHUM fpica oblonga ovata, flofculis fubpedunculatis arifta longioribus. Sy $f_{6}$ Nat. 67. (Stillingf: Mifcel.t. i.)

Verral Grafs. Anglis.

In meadows and paftures frequent. 2 . V.

It is one of the earlieft graffes that flowers; and Stillingfleet fays it gives a grateful odor to hay. 
$\begin{array}{llllllll}C & L & A & S & S & I & S & \text { III. }\end{array}$

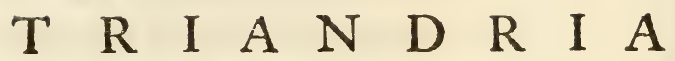
$M O N O G$ Y N I A. * Flores Juperi.

VALERIANA. Cor-5-fida, bafi gibba. Sem. I. IRIS. Cor. 6-petaloidea: Petalis alternis reflexis. Stigma petaloideum.

* Flores graminei valvulis Glume calycine.

SCHOENUS. Cor. nulla. Cal. paleis fafciculatis. Sem. fubrotundum.

SCIRPUS. Cor. nulla. Cal. paleis imbricatis. Sem. nudum.

ERIOPHORUM. Cor. nulla. Cal. paleis imbricatis. Sem. lanigerum.

NARDUS. Cor. bivalvis. Cal. nullus. Sem. tectum.

$$
\begin{aligned}
& \text { D I } \quad G \quad Y \quad N \quad I \quad A . \\
& \text { Flores unifuri vagi. }
\end{aligned}
$$

ALOPECURUS. Cal. bivalvis. Cor. univalvis apice fimplici.

PHLEUM. Cal. bivalvis tranctus, mucronatus fefrilis. 
PHALARIS. Cól. bivalvis; valvis carinatis æqualibus, corollam includentibus.

MILIUM. Cal. bivalvis; valvis ventricofis corolla majoribus.

AGROSThIS, Cal. bivalvis; valvis acutis corolla brevioributs.

DACTYLIS. Cal. bivalvis; valva majore longiore comprefia carinata.

$\dagger$ Arundo calsmagroftis; arenaria.

** Flores bifiori vagi.

AIRA. Cal. bivalvis. Flofcul: abfq; rudimente tertii.

MELICA. Cal. bivalvis. Rudimento tertii inter flofculos.

*** Flores multiflori vagi.

BRIZA. Cal. bivalvis. Cor. cordata; valvis ventricolis.

POA. Cal. bivalvis. Cor, ovata; valvis acutiufculis,

FESTUCA. Cal. bivalvis. Cor. oblonga; valvis mucronatis:

BROMUS. Cal. bivalvis. Cor obsonga; valvis fub apice ariftatis.

AVENA: Cal. bivalvis. Cor. obionga; vaivis dorfo arifta contorta. 
ARUNDO. Cal. bivalvis. Cor. bafi lanata mutica.

* Dactylis glomerata.

**** Flores multiflori, infidentes receptaculi elongati dentibus.

TRITICUM. Cal. oppofitus, multiflorus, bivalvis, folitarius.

HORDEUM. Cal. lateralis, uniflorus, bivalvis, ternus.

ELYMUS. Cal. lateralis, multiflorus, bivalvis, binus, ternufve.

L.OLIUM. Cal. lateralis, multiflorus, univalvis, folitarius.

CYNOSURUS. Cal. bivalvis, multiflorus. Recept. proprium unilaterale, foliaceum.

$$
\begin{array}{lllllllllll}
T & R & I & G & Y & N & I & A
\end{array}
$$

MONTIA. Cor. r-petala. Cal. diphyllus. Caps. 3-valvis, 3-fperma. 


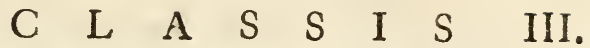

\section{$M O N O G \quad Y N$ I $A$.}

VALERIANA. Lin. Gen. 44.

Cal. nullus. Cor. 1-petala, bafi hinc gibba, fupera. Sem. unicum.

officinalis I Valeriana floribus triandris, foliis omnibus pin natis. Lin. Sp.pl. 45. (Ger. Em. 1075,f.2)

Great wild Valerian. Anglis:

In ditches and marhy places frequent, and fometimes in dry mountainous paftures. 2f. VII.

The roots are efteem'd an excellent nervine: cats are very fond of the fmell of it.

dioica 2. V. floribus triandris dioicis, foliis pinnatis integerrimis. Sp.Pl. 44. (Ger. Em. 1075. f. 3.)

Small wild Valerian. Anglis.

In marhy meadows frequent. 4 . VII.

The radical leaves of this are oval; of the preceding they are pinnated: the flowers of the male are much larger than the female.

locufta 3. V. floribus triandris, caule dichotomo, foliis linearibus ip. Pl. 47. (Ger. Em. 3 IO. f. I.)

Corn-Sallet. Ainglis.

In corn fields. $\odot . V$.

The radical leaves in the Spring are well known as fallet. 


\section{TRIANDRIA MONOGYNIA.}

\section{IRIS. Lin. Gen. 59 .}

Cor. 6-partita; petalis alternis reflexis. Stigmato petaliformia,

peadacorus IRIS corollis imberbibus, petalis interioribus ttigI.

mate minoribus, foliis enfiformibus. Lin. Sp. Pl. 56. (Oed. Den. 494. opt. Ger. Em. 50.f. 2.)

Yellow Water Flowẹr-de-luce. Anglis.

Seilifdeir. Goulis.

By the fides of ditches, and in marhy places frequent. 4. VII.

In Arran, and fome other of the Weftern ines, the roots are ufed to dye black; and in Fura they are boil'd with copperas to make ink.

\section{SCHOENUS. Lin. Gen. 65.}

Glume paleacex, univalves, congenta. Cor. o. Scm.

I. fubrotundum inter glumas.

\section{* Culmo tereti.}

"izricans 1. SCHOENUS culmo tereti nudo, capitulo ovato, involucri diphylli valvula altera fubulata longa. Sp: Pl. 64. (Moris. Itift. Ox. Sezt. 8.t. 10.f. 28.) Black-headed Bog-Ruih. Anglis. On moors and peat-bogs common. 4. VII,

ferrugineus S. culmo tereti nuido, fpica duplici, involucri val2. vula majore fpicam xquante. $S p \cdot p i, 64$. (Moris. Hift. Ox. Seci. 8. t. 12.f. 40)

Brown-headed Bog-Rufh. Anglis.

In moorifh places, rare: in the inand of Miull. 4. VII. 


\section{* Culmo triquetro.}

comprefus 3 S. culmo fubtriquetro nudo, fpica difticha, involucro monophyllo. Sp. Pl. 65, (Pluk. Phyt. t. 34. $f \cdot g \cdot)$

Compreffed Bog-Rufh. Anglis.

In marhy places by the fides of lochs in Ilay, but not common.

albus 4. S. culmo fubtriquetro foliofo, floribus fafciculatis, foliis fetaceis. Sp. Pl. 65. (Oed. Dan. 320. Hift. Ox. S. 8. t. 9.f. 39)

White-flower'd Bog-Ruh. Anglis.

On moors and peat bogs commo:1. 4. VII.

\section{SCIRPUS. Lin. Gen. 6\%.}

Glume paleacex, undique imbricatx. Cor. o. Sem. 1. inberbe.

* Spica unica.

paiuftris 1 . SCIRPUS culmo tereti nudo, fpica fubovata terminali. Sp.Pl. 7o. (Fl. Dnn.273. opt. Moris. Hift. Ox Sect. 8. t. 10. fg. 32. Loefel. Pruff. t. 36. benè. Ger. Em. 1630.)

Cluh Ruh. Anglis.

In ditches and by the fides of lochs frequent. 4 . VII.

6aspitofus 2 S. culmo ftriato nudo, fpica bivalvi terminali longitudine calycis, radicibus fquamula interftinctis. 'p. Pl. 71. (Oed. Dan. 167. Pluk. Pbyt. t. 40. f. 6.)

Heath 
88

\section{TRIHNDRIA MONOGYNIA.}

\section{Heath Club-Rufh. Angiis.}

In heaths and moors frequent. 4 , VII.

acicularis 3 S. culmo tereti nudo fetiformi, fpica ovata bivalvi, feminibus nudis. Sp. Pl. 71. (Oed. Dan. 287 . Pluk. Ph. t. 40. f. 7. Moris. Hitt. Ox. S. 8. t. 10.f. 37.)

Little upright Club-Rufh.

On the fides of lochs immers'd even under the water, and in marhy places, about a mile $\mathrm{N}$. Weft from Lafwade. Dr. Parjoins. 4t? VIII.

fuitans 4. S. culmis teretibus nudis alternis, caule foliofo flaccido. Sp. Pl. 71. (Moris. Hift. S. 8. t. 10. f. 31. Pluk. Pb. 35.f. 1.)

toating Club-Rurh. Anglis.

$I$ obferv'd plenty of it by the fides of the little lochs in the inland of Rum : without doubt it may be found in many other fuch-like places. In pits where water has ftood for fome time is its proper place of growth. 24. VII.

\section{** Culmo tereti polyftacbio.}

faitris 5. SCIRPUS culmo tereti nudo, fpicis ovatis pluribus pedunculatis terminalibus. $S_{p} . P ! \cdot 72$. (Moris, Hijt. Ox. SeE. S. t. 10. f. 1. Ger. En. 35.f. 3.) Bull-Rufh. Anglis.

In clear ftill waters frequent. 2. VII.

This rufn is ufed to make bafkets, mats, and feats for chairs.

jescerts f, S. culmo nudo fetacco, fpicis lateralibus fubfolitaris fenilibus. 
feffilibus. Sp. Pl. 73. (Oed. Den. t. 31 I. Hijt. Ox. (eEt. S. t. IO. f. 23.)

The left. Ruh. Anglis.

In wet, fandy, or gravelly places; but not very common, 0 . VII. VIII.

** Culmo triquetro, panicula foliacea.

maritimns 7 S. culmo triquetro, panicula conglobata foliacea, fpicularum fquamis trifidis, intermedia fubulata. Sp. Pl. 74. (Moris. Hift. Ox. .. 8. t. 11.f.25. E3 fortale $f .9$.)

Round rooted Baftard Cyperus. Anglis.

On the rea coafts not unfrequent. 4. VII.

Jylvaticus 8 S. culmo triquetro foliofo, umbella foliacea, pedunculis nudis fupradecompofitis, fpicis confertis. Ep. pl. 75. (Oed. Dan. 307. Moris. Hift. Ox. J. 8.

t. I1.f. 15. Lafel, Pruff. t. 33. bona.)

Millet Cyperus-Grafs. Anglis.

In moift woods near Rofin caftle. Dr, Parfons. 4. VII.

\section{ERIOPHORUM. Lin. Gen. 68.}

Glume paleaceæ, undiq; imbricatæ. Cor. o. Seni. 1. Lana. longifima cinctum.

polyftachion ERIOPHORUM culmis teretibus, foliis planis, 1. fpicis pedunculatis. Sp. pl. $; 6$. (Moris. Hift. Ox. f. 8. t. 9.f. 1. ad imum. Ger. Em. 29. f. 1. V'aill. Botan. Peris t. 16.f. 1. 2. bona.)

Cotton-Grafs. Anglis.

On moors and peat-bogs very frequent. 4. VII. 
9o

eaginatumn 2.

\section{TRIANDRIA MONOGYNIA.}

E. culmis vaginatis teretibus, spica fcabiofa. $S p$. pl. 76. (Oed. Dan. 236. Moris. f. 8. t. 9. f. 6. ad imum. Scheuch. Gram. 302.t. 7. f. I, bené.)

Hiares-Tail-Rufh. Anglis.

It grows in the fame kind of places with the preceding, and nearly as common. 4 . IV-VII.

It is readily diftinguifhed from the firft fort, as it bears only one fingle erect oval fpike at the top of the ftalk.

\section{NARDUS. Lim. Gen. 69 :}

Cal. nullus. Cor. bivalvis.

frrizta 1. NARDUS fpica fetacea recta fecunda. Syjt. Nat. 84. (Moris Hift. Ox. .. 8. t. 7.f. 8. bona Scbreb. Gram.65. t. 7.)

Mat-Grafs. Ainglis.

On moors and heaths frequent. 24. VI.

\section{I G Y}

PHALARIS. Lin. Gen. 74 .

Cal. bivalvis, carinatus, longitudine xqualis, corollain includens.

arundinacea PHALARIS panicula longa ventricớa ampla. I.

Syft. Nat. 86. (Oed. Dan. 259. Moris. Hift. Sect.

8. t. 6.f. 4I. L.oes. Pruff. No. 34.)

Reed Canary-Grafs. Anglis.

On the fides of lakes and rivers frequent. 4. ViI.

\section{PHLEUM. Gen. Pl. 77 .}

Cal. bivalvis, fefilis, linearis, truncatus, apice bicufpidato. Cor. inclufa. 
praten fe I. PHLEUM fpica cylindrica longiflima ciliata, culino erecto. ip.pl. 87. (Moris. Hitt. Ox. .. 8. t. 4.f. r. in imo ad finiftram.)

Meadow Cat's Tail, or Timothy Grafs. Ang.is. By way-fides and in paftures, but not common, 4. VII.

nodofum 2. P. Spica cylindrica, culmo afcendente, foliis obliquis, radice bulbofa. Syft. Nat. 88. (Oed. Dan. t. 380 . Moris. Hift. Ox. . 8, t. 4.f. 3. in imo. Barrel. t. 53.)

Bulbous Cat's-Tail Grars. Anglis.

In paftures and by way-fides, 24. VII. VIII.

The limits between this and the preceding, in fome fituations of growth, are fcarcely dicernible: perhaps they are only varieties, but as the beft writers have feparated them, I was unwilling to conjoin them.

\section{ALOPECURUS. Gen. Pl. 78.}

Cal. bivalvis. Cor. univalvis.

piatenfis x. ALOPECURUS culmo fpicato erecto, giumis villofis, corollis mutic s. Syjt. Nat. 89 . (Stillingf. Tract.t. 2. bonc. Ger. Em. 11. fig. finift.)

Meadow Fox Tail Grafs. Anglis.

In moitt meadows frequent. $น . V$.

It is efteem'd a good grafs for hay.

egreftis 2. A. culmo fpicato erecto, glumis lavibus. syft. Nat. 8g. (Moris. Hift. Ox. S. 8. t. 4.f. 8. छ\$ 12, Bon. Barrel. Ic. t. 699. f. I. 2. Schreb. Gram. I40. t. 19.f. 2, Ger. Em. 11. fig. dextera.) 
Field Fox Tail Grafs. Anglis.

In corn fields and by way-fides. 24. VI. VII.

The fpike of this is much longer and flenderer than that of the preceding, and is of a reddifh color.

geniculatus ALOPECURUS. culmo fpicato infracto, corollis 3. muticis. Syft. Not. 89. (Ger. Em. 14. f. 2. Schcuch. Grañ. t. 3.f. 6. C. D. E. Moris. Hift. f. 8. t. $4 \cdot f$. I5. melicr.)

Flote Fox-Tail Grafs. Anglis.

In places where water has ftood in the Winter. 24. VII. VIII.

\section{MILIUM. Gen pl. 79.}

Cal. bivalvis, uniforus. Corolla brevifima. Stigmata penicilliformia.

afwn 1. MIIIUM floribus paniculatis difperfis muticis. sp.pl.g0.(Moris. Hift. On. f.8.t. 5.f. 10. benè.) Millet-Grafs. Anglis.

In fhady woods, but not common. Dr. Parfons. $\odot$ ? VI.

\section{AGROSIIS. Gen. pl. So.}

Cal. 2.valvis, unillorus, corolla paulo minor. Stigmatı longitudinaliter hifpida.

$$
\text { * Ariftate. }
$$

crinin 3. AGROSTIS calycibus elongatis, petalorum arifta dorfali recurva, culmis proftratis fubramofis. Syft. Nat. 9o. (Scbeuch. Gram. p. 1 41.t. 3.f. 9 . C): 


\section{- TRIANDRIA DIGYNIA.}

Brown Bent-Grafs. Anglis.

Upon peat.bogs frequent. 4. VII.

** Mutice.

ftolonifera 2 A. panicula ramulis patentibus muticis, culmo repente, calycibus æqualibus. Syt. Nat. 90. Sp. pl. 93. (Ger. Em. p. 26.f. I.)

Creeping Bent-Grafs. Anglis.

In fandy or gravelly places that have lain under water in the Winter. 4. VIII.

The ftalk reclines on the ground towards it's bare, and throws out young hoots at the joints.

alba 3. AGROSTIS panicula laxa, calycibus muticis æqualibus. Sp.pl.g3. (Moris. Hift. S. 8.t.6.f. 27.)

Marfh Bent-Grafs. Anslis.

In ditches and moift meadows. 4. VII.

This is a much larger grafs than the preceding, and grows erect; but in other refpeets differs fo little from it, that perhaps it would be no error to confider it only as a variety.

capillaris 4 A. panicula capillari patente, calycibus fubulatis æqualibus hifpidiufculis coloratis, flofculis muticis. Sp. pl. 93. (Oed. Dan. t. 163. opt. Stillingf. Mifcel.t. 3.)

Fine Bent-Grafs. Anglis.

In meadows and paftures frequent. 24. VIII.

The llowers of thefe three laft have all a night roughnefs, and are extremely related to each other: this laft however is the finest and moft delicate 


\section{TRIANDRIA DIGYNIA.}

delicate grais of the three, and grows erect, without any hoots at the joints.

\section{A I R A. Gen. pl. 8 I.}

Cal. bivalvis, biflorus. Flofculi abfque interjecto rudimento.

* Mutica.

equatica I. AIRA panicula patente, floribus muticis lævibus calyce longioribus, foliis planis. Syft. Nat. $9 \mathrm{r}$. sp. pl. 95. (Oed. Dan. t. 38 1. Vail. Paris. t. I 7: f. 7.)

Water Hair-Grafs. Anglis.

On the banks of rivulets and ponds, but not very common. 4. VI.

It varies, fometimes with five or fix flowers in a calyx, when it happens to get in a dry foil, and then puts on the appearance of a Poa.

$$
\text { * Ariftate. }
$$

caspitofa 2. AIRA foliis planis, panicula paterite, petalis bafi villofis ariftatifq; arifta recta brevi. Sp. pl. 96. (Moris. Hift. Ox. . 8.t. 5.f. 1 7. Ger. Em. p. 5. f. 2. quoid paniculam Sed non folia) Turfy Hair Grafs. Anglis.

In wet paftures and moift woods. 24. VII. VIII. The ftalk is a yard high : the panicle often a foot long, and when not in flower leans all one way: the leaves grow in a thick turf, are plain, rigid, and rough to the touch: the panicle confifts of a vaft number of fmall flowers, which have a grey-purple filvery appearance. 
flexuofa 3. A. foliis fetaceis, culmis fubnudis, panicula divaricata, pedunculis flexuofis. Sp. pl. 96. (Oed. Dan. t. 157. opt. Moris. Hift. S. 8. t. 7.f 9. int imo ad dextram. Stillingf. Mifcel. t. 4. Scbeucb. Gram. 218.t.6.f. 1. E' t. 4.f. 4.)

Mountain Hair-Grafs. Anglis.

In heaths and mountainous paftures. 2 . VII.

The ftalk is about a foot high, bearing a loofe open panicle of filvery purple flowers. On rocks and in woods it frequently varies with white flowers, which has been diftinguifhed by fome as a fpecies. pracox 4. A. foliis fetaceis; vaginis angulatis, floribus paniculato-fpicatis, flofculis bafi ariftatis. $S p p l .97$. (Oed. Dan. t. 383. opt. Raj. Ang. 3. p. 408.t. 22. $f$. 2.)

Early Hair-Grafs. Anglis.

In fandy barren paftures. Dr. Parfons. $\odot . V$.

This is not above three or four inches high, and bears a fhort clofe panicle of whitilh green flowers.

caryophy A. foliis fetaceis, panicula divaricata, flcribus 5. ariftatis diftantibus. Sp. pl. (Oed. Dan. t. 382 . Sillingf. Mifcel. t. 5. Moris. Hift. Ox. . . S. t. 5. f. II.)

Silver Hair-Grafs. Anziis.

In tandy and barren paftures. Dr. Parfons. ๑. V. MELICA. Gen. pl. 82 .

Cal. bivalvis, biforus. Rudimentum floris interflofculos. nutens I. MELICA petalis inberbibus, panicula nutante fimplici. Sp.p. 98. (Moris Hift. Ox. f. 8. t. 7 . f. 48 . E ejus Varietas f. 49.) 
Melic-Grafs. Anglis.

In thady woods not uncommon: it's variety witi flowers nearly feffile, growing in a fpike inftead of a panicle. I oblerv'd in Lord Breadalbane's woods at Ardmadd, in Nether-Lorn. The calyces of both are of an auburn color, and the flowers within them green. 4. VI-VIII.

sxrulia 2. M. panicula coaretata, foribus cylindricis. Lin. Mantiss. p. 325. Aira cerulea Sp. pl. 95. (Oed. Dan. t. 239. Moris. Hift. Ox. S. 8. t. 5.f. 22.) Purple Melic-Grafs. Anglis. Pund-Glafs. Gaulis. In wet, moorih, and barren ground frequent. 4 . VIII.

This grafs is readily diftinguifhed by it's black purple panicle: it has a bulbofe root, blue antherx, and a purple piftil, with two or three flowers in a calyx.

The fithermen in the ine of Skie make ropes for their nets of this grafs, which they find by experience will bear the water well without rotting.

\section{$\mathrm{P} \bigcirc$ A. Gen. pl. $8_{3}$.}

Cal. bivalvis, mulitilorus. Spiculc ovata; valvulis margine fcaliofis acutiufculis.

aifina r. POA panicula diffufa ramofifima, fpiculis fexfloriș cordatis. Sp. pl. 99. (ejus. varites vivipara Scbeuch. Iter Alp.p. 3S. t. 4. f. 2. E Agrofo. graph.p. 22. t. 4.f. 1 4.)

Alpine Meadow-Grafs. Anglis.

On the fides of Craiz-cballeach, above Finlarig, in Ercadalbane. Mir. Stuart. 24. VI.

The 
The fpecimen 1 faw was the viriparous kind: the leaves are fmooth, compreffed, and a little recurv'd: the ftalk is five inches high, nender, and purple: the panicle open, and thinly fet with flowers: the calyces of a purple color: the germina viviparous.

bivialis 2. P. panicula diffufa, fpiculis trifloris bafi pubefcentibus, culmo erecto tereti. Sp. pl. 99\% (Ger. Em. p. 2. f. 2.)

Common Meadow-Grafs. Anglis.

In meadows almoft every where. 4. VI.

anguftifolic P. panicula diffufn, fpiculis quadrifloris pubefcenti3 . bus, culmo erecto tereti. sp. pl. 99. (Moris. Hift. S. 8. t. 5.f. 19.)

Narrow-leav'd Meadow Grafs. Anglis. In woods and hedges. 2\}. VII.

pratenfis 4. P. panicula diffufa, fpiculis quinque floris glabris, culmo erecto tereti. Sp. pl.99. (Moris. Hift. Ox. f. 8.t. 5.f. I8. Ger. Em. P. 2.f. I.)

Great Meadow-Grafs. Anglis.

In rich meadows. 2. VI.

Thefe three laft are efteem'd amongit our bcit graffes for hay.

amua 5. P. panicula diffufa angulis rectis, fpiculis obtufis, culmo obliqùe compreffo. Sp.pl. 99. (Stillingf, Mifcel. t. 7. bona Ger. Em.p. 3.f. 2.)

Annual Meadow-Grafs. Anglis.

In meadows and by way fides. $\odot$. IV-IX.

comprefja $\sigma_{b}$ P. panicula coaretata fecunda, culmo obliquo com- 
preffo. Sp.pl. ror. (Vaill. Paris. t. 18.f. 5.)

Flat ftalk'd Meadow-Grafs. Anglis.

On walls at Mellro/s-Abbey, \&c. $\odot$ ? VI.

When growing upon walls it has commonly about three flowers in each fpicula; when it defcends into paftures or moift ground it has fix or more.

memoralis 7 P. panicula attenuata, fpiculis fub-bifloris mucronatis fcabris, culmo incurvo. Sp.pl.102. (Scbeucn Agroft. 164. t. 2. fig. dextra. Iter. 2. p. 135. $t$. 18. $f .3$.)

Wood Meadow-Grafs. Anglis.

In woods and thady places not unfrequent. 4 ? VII.

It has a weak ftalk above a yard high: a nender nodding panicle of pale green flowers: the glumes of the calyx are ftreak'd with fine lines.

maritimas. P. panicula fubficicata, fpiculis fecundis coarctatis, foliis convolutis. Hudf. Fl. Ang. 35. (Oed. Dan. t. 25 1.)

Sea Meadow-Grafs. Anglis.

On the fea coafts in many places: I obferv'd it in the inand of Oransa, and in Skye at Dunvegan caltle, and at Locb-Broom in Rofs-foire 24. III. The ftalks are about fix inches high, bent at the joints : the calyces are edg'd with purple: the fpicula nearly cylindrical, each confifting of fix or eight flowers. It is very nearly related to the fettuca fluitans; perhaps the fea water may occafion the difference.

criftata g. P. panicula fpicata, calycibus fubpilofis fubquadriforis 
foris pedunculo longioribus, petalis ariftatis. Syft. Nat. 94. Aira criftata. Sp.pl. 94: (Moris. Hift. S. 8. t. 4.f. 7. Loef. Pruf. f. I 10. n. 22. bon.)

Criited Poa Grafs. Anglis.

In dry and mountainous paftures frequent. 2 . VII. This grafs is about five or fix inches high: the leaves and falk downy: the panicle clofe like a fpike, of a white or greyin color; with purple antheræ.

\section{BRIZA. Gen. Pl. 84.}

Cal. bivalvis multiflorus. Spiculo difticha, valvulis cordatis, obtufis; interiore minuta.

medifa I. BRIZA fpiculis ovatis, calyce flofculis ( 7 ) breviore. Sp. pl. 103. (Oed. Dan. t. 258. Moris. Hijt. S. 8. t. 6. f. 45 . Zeni.)

Cow-quakes, Quaking-Grafs. Anglis.

In meadows and paftures, but rare in the highlands.

\section{DACTYLIS. Gen. Pl. 86.}

Cal. bivalvis, comprefius; altera valvula majore carinata.

gloneratus DACTYLIS panicula fecunda glomerata. Lin. Sp. I. pl. 105. (Mcris. Hift. Ox. .. 3.t. 6.f. 38 . Bavb. Prod. 9. fig. finiftra.)

Rough Cock's-Foot Grafs. Anglis.

By way-fides and under hedges frequent. 4. VII.

It is a very troublefome creeping grafs in a garden, and difficult to be deftroy'd. The gardeners call 
this, and feveral other creeping kinds, CouckGrajs.

\section{CYNOSURUS. Gen. Pl. 87 .}

Cal. bivalvis, multiflorus, Recpt. proprium unilaterale, foliaceum.

criftalus 1. CYNOSURUS bracteis pinnatifidis. Sp. pl. 105. (Oed. Dan. t. 239. opt. Barel. ic. 27. Scbreber. t. 8.)

Crefted Dog's-Tail Grafs. Anglis.

In dry paitures frequent. 24. VII.

This is efteem'd an excellent grafs to feed fheep and deer.

curatius 2. CYNOSURUS bracteis integris. Sp.pl. 106. (Arduin. Spec. 2.p.18. t.6. fig. 3.4. 5. Scbeuch. Gram. p. 8.. t. 2. f. 9. A. B. Baub. Prod. p. 2 1. n. 73. cum lione. Sed malè.)

Blue Dog-Tail Grafs. Anglis.

In wet places on the fides of the mountains about Little-Locb-Broom, in Rofs-Jire, \&c. 24. VI. VII. I he root is thick and white: the ftalks from twelve to eighteen inches high: the leaves plain, fheathing the ftalks at the bafe: the flowers grow in a clofe imbricated fpike, three-fourths of an inch long, and nearly oval, of a blue or grey color: the involucrum of each fpicula confifts of two oval acuminated giumes, of equal fize, and filvery color, fubtending one, two or three flowers, of a blue or grey color : the exterior valve of the flower is truncated, and terminated 
with three equal points, or fhort beards; the interior with only two.

\section{FESTUCA. Gen. Pl. 88.}

Cal. bivalvis. Spicula oblonga teretiufcula, glumis acuminatis.

* Panicula Secunda.

orina I. FESTUCA panicula fecunda coarctata ariftata culmo tetragono nudiufculo, foliis fetaceis. $S p$. fl. 108. (Loes. Pruf. п го. n. 24. Moris. Hijt. S. 8.t. 3. f. 13. Pluk. Phyt. t. 34. f. 2. Stillingf. Mifcel. t. 8.)

Sheeps Fefcue Grafs. Anglis.

In dry pantures frequent. 4 . VI.

The flowers, vary with and without ariftæ. It is an excellent grafs for theep paftures.

civipara 3. F. fpiculis viviparis. Sp.pl. 108. (Raj. Syn. 408. t. 22. f. 1. Scbeuch. Gram. 213.t. 1.bon.) Viviparous-Fefcue Grafs. Anglis.

Upon rocks and mountains frequent. 4. VII.

This is only a variety of the preceding, the germira thooting before the feeds are ripe.

duriufcula 2 F. panicula fecunda oblonga, fpiculis 6-floris oblongis !revibus, folis fetaceis. sp. pl. 108. (Raj. Syn. p. 379.t. 19. f. 1.)

Hard Fefcue-Grafs. Anglis.

In dry paftures, and upon rocks in the craig of Ailfa abundantly. 24. VI.

$\mathrm{H} 3$

The 
The radical leaves are filiforme and channelled, thofe on the ftalk plain.

pubra 3. F. panicula fecunda feabra, fpiculis 6-floris ariftatis; fofculo ultiro mutico, culmo femiteriti. sp.pl. Ic9. (Stillingf. Mifcel.t. 9 ?)

Purple Fefcue-Grafs. Anglis.

In dry mountainous paftures. The inle of Canay, abounds with this and the F. ovina. 24. ViI.

bromoides + F. panicula fecunda, fpiculis erectis lrvibus, calycis altera valvula integra, altera ariftata. Sp. pl. 110 (Pluk. Pbyt. t. 33.f. 10.)

In dry paftures, but not common. $\odot$. VI.

The ?talks frequently decline towards the ground.

claticr 5. F. panicula fecunda erefta, fpiculis fubariftatis exterioribus teretibus. Sp. pl. II1. (Moris. Hift. Ox. $.8 . t .2 . f$. i 5.$)$

In moift rich meadows, but not common. Dr. Parfons. 24. VII.

It is a grafs that makes, moft excellent fodder for cattle.

\section{: Ponicula aquali.}

decumbens FESTUCA panicula erecta, fpiculis fubovatis mu6. ticis, calyce flofculis majore, culmo decumbente. Sp.pl. 110. (Oed. Dan. t. 162. opt. Moris. Hift. f. 8.t. 1.f.6. Pluk. Pbyt. t. 34.f. 1.)

Decumbent Fefcue-Grals. Anglis.

In dry mountainous paftures. I faw no where fuch 
fuch plenty of it as in the illand of Cancy. 24. VII.

fluitans 7. F. panicula ramofa erecta, fpiculis fubfefilibus teretibus muticis. Sp.pl. I11. (Moris. Hift. S. 8. 6. 3. f. 16. Stillingf. Mifcel. t. 10.)

Flote Fefcue-Grafs, Anglis.

In ditches and watery places frequent. 24.VII.

This grafs is of a fucculent nourifhing quality, and cattle are very fond of it. It would doubtleis be a good kind to fow in wet meadows.

The feeds of this grafs, are in Poland and Germony

brought to the tables of the great, as an agreeable and nourifhing food, under the name of Manna Seeds.

fylvatica 8. F. fpicata, fpiculis alternis fubdiftichis femilibus ariflatis. Huds. Fl. Ang. p. 39. Bromus pinnatus. Lin. (p. pl. (Oed. Dait. t. 16+t) Wood Fefcue-Grafs. Anglis.

In woods and hedges not uncommon. 4. VIII. The beards arife from the extremity of the glumes: it is therefore properly a feftuca, tho' it has the habit of a bromus, the laves being hairy, the fpiculix rough, and the beards long.

\section{BROMUS, Gen. Pl.. 89 .}

Cal: bivalvis. Spicula oblonga, teres, difticha; arifta infra apicem.

mollis r. BROMUS panicula erediufcula, fpicis ovatis pubefcentibus ; ariftis rectis, foliis mollifimè villofis. 
villofis. Sp.pl. 1I2. (Moris. Hif. Ox. ..8. i. \%

f. I 8. Eं ejus varietas. f. 19.)

Sofi Brome-Grafs. Anglis.

In meadows and on dry banks. $\odot \mathrm{VI}$.

arvenfis 2. BROMUS panicula nutante, fpiculis ovato oblongis. Sp.pl. I I 3. (Oed. Dan. 293.)

Corn Brome Grafs. Anglis.

I found what I talse to be a very fingular variety of this upon the fandy thore in the inland of Oronfay. The stalks were about five inches high: the radical leaves imooth, ftiff, channelled and fubulated; thofe on the ftalks broader, fheathing it like Spatba: the clofe panicle, or rather fpike, conlifted of eight or ten fpiculx, nearly feffile, and growing on one fide of the falk: thefe fpiculæ were fmooth ${ }_{2}$ without beards, exactly like thofe in the figure referr' $c_{1}^{\lambda}$ to, confifting each of about five flowers. I apprehend the fea-water occafions the convolution of the leaves, and the poverty of the foil the other differrences. $\odot$. VII.

Aerilis 3. B. panicula patula fpiculis oblongis diftichis, glumis fubulato-ariftatis. $S p$. pl. 113. (Moris. Hift. Ox. Sez. 8.t. 7.f. 1 1. Ger. Em. 76.f. 1. beni.) Barren Brome-Grafs. Anglis.

In hedges and on walls and dry banks. $\odot$. VI.

giganteus 4 EROMUS panicula nutante, fpiculis quadrifloris arifis brevionibus. Sf. pl. xrit. (Yaill. Botan。 paris. t. 18 f. 3.) 
Tall Brome-Grafs. Anglis.

in fhady woods, as at Armaddy, in Netber-Lorn, 8c. 4. VIII.

\section{AVENA. Gen. Pl. 9 1.}

Cal. bivalvis, multiflorus; arifta dorfali contorta. flatior I. AVENA paniculata, calycibus bifloris flofculo, hermaphrodito fubmutico, mafculo ariftato. $S_{p}$. pl. 117. (Oed. Dan. 165. Moris. Hift. S. 8 t. 7. f. 37 E. 3 . Baub. Prod.p. 3. fig. ad dext.)

Tall Oat-Grafs. Anglis.

Swines Ar-Nuts, or Earth-Nuts. Scotis. In hedges and paftures frequent. 4 . VII.

It varies with fibrous roots, or with feveral tubercles laid upon one another.

fotua 2. A. paniculata calycibus triftoris, flofculis omnibus bafi pilofis; ariftis totis levibus. Sp. pl. 118 . (Moris. Hift. f: 8. t. 7.f. 5. Barrel. ic. 75.n. 2.) Bearded Oat-Grafs. Anglis.

In corn fields. Sibbald. $\odot$. VII.

The beard of this is well known to make a very fenfible hygrometer. The feeds have a hairy Rind.

pubefcens 3. A. fubfpicata, calycibus fubtrifloris bafi pilofis, foliis planis pubefcentibus. Sy/t. Nat. 99. (Raj. Syn. 406. t. 2I. f. 2.)

Soft Oat-Grafs. Anglis.

On dry mountainous paftures. 24. VI. VII.

pratenjis 4. AVENA fubfpicata, calycibus 5-Horis. Sp. pl. Irg.

Rnj. 
(Raj. Syn. 406.t. 21.f. 1. bona. Moris. Hit. S. 8. t. 7.f. 2 1. Vaill. Par. t. 18.f.1.)

Meadow Oat-Grafs. Anglis.

On dry mounntainous paftures about Blair, \&c. 4. VII.

The leaves are fmooth, narrow, ftiff, their edges frequently turning inwards: the fpicula grow parallel to the ftaik, and clofe to it, generally but one or a peduncle.

favefcens 5 A. panicula laxa, calycibus trifloris brevibus, flofculis omibus ariftatis. Sp.pl. 118. (Moris. Hift. f. 8.t.7.f. 42. Scbreb. Gram. 72.t.9)

Yellow Oat-Grafs. Anglis.

In dry meadows and paftures. Dr. Perfons. 4 . VII. The panicle is compofed of numerous ipiculæ, much fmaller than in any of the other fpecies, and of a yeilowifh color.

\section{ARUNDO. Gen. Pl.93.}

Cal. bivalvis. Flofculi congefti, lana cincti.

pioregmiles ARUNDO calycibus quinquefloris, panicula laxa. I. sp. pl. 120. (Moris. Hift. S. 8. t 8. f. 1. Ger. Em. 36.f. I.)

Common Reed-Grais. Anglis.

On the fides of lochs and in ditches frequent. $2 \%$ VII.

calainagros-ARUNDO calycibus uniforis, culmo ramofo. Sp. tis 2 .

pl 121. (Oed. Dan. t. 280. Moris. IJift. f. 8. $t$. 8. f. 2. Scbeucb. Gram. 122.t. 5. benè) 
Branched Reed-Grars. Anglis.

In thady moift places, but not common. 24. VII.

arenuria 3. A. calycibus unifloris, folis involutis mucronatopungentibus. Sp.pl. 121. (Moris. Hijt. S. 8.t. 4. f. 16.)

Sea Reed-Grafs. Anglis. Bent. Scotis.' Muran, Gaulis.

On the fea fhore in fandy places not unfrequent, as on the coaft of Cantire, between Macbrianifis bay and Barr, and near Aberbrotbick, in Angus, \&.c. 24. VII.

\section{LOLIUM. Gen. $\mathrm{Pl} .95$.}

Cal. monophyllus, fixus, multifiorus.

percine 1. LOLIUM fpica mutica, fpiculis compreflis multifloris. Sp. pl. J 22. (Moris. Hift. f. 8. t. 2.f. 2. Ger. Em. 78. f. 2.)

Perennial Darnel-Grafs. Anglis. By way-fides and in partures common. 24. VI.

teinulentum L. Spica ariftata, fpiculis diftantibus compreffis 2. multiforis. Syft. Nat. 100. (Oed. Dan. t. 160.) Annual Darnel-Grafs. Anglis.

In corn fields, but not common. Dr. Parfons. $\odot$. VIII.

The leeds of this grafs will intoxicate man, birds, and beafts; and taken in any confiderable quantity will bring on convulfions and death. Haller. Helvet. 205, 206. 


\section{ELYMUS. Gen. Pl. 96.}

Cal. lateralis, bivalvis, aggregatus, multiflorus.

arenarius 1. ELYMUS fpica erecta arkta, calycibus tomentofis flofculo longioribus. Sp.pl. r22. (Fig. mulla, quam fcio, credenda. Hig. 14. .. 8.t. 4. Moris. Hift. Ox. appropinquat, Jed spica nimis parva Eे brevis, noc tomentofa.)

Sea Lime-Grafs. Anglis.

On the fea coaft in fandy places, but not common. 4. VI, VII.

The leaves are channeled, rigid and pungent: the fpike linear, downy, and about eight or nine inches long. The creeping roots of this grafs, and the arundo arenaria, confine the fea fands from being hlown about by the winds, and by that means prevent often very deftructive inundations.

ccminus 2. ELYMUS fpica nutante act fa fpiculis rectis involucro deftitutis, infimis geminis. Sp. pl. 124. Triticum caninum. Huds. Fl. Ang. 45. (Moris. Hift. J. 8. t. I.f. 2.)

Dog's Lyme-Grafș. Anglis.

In dry hady upland woods. Dr. Parfons.

In the den of Bethaick, near Perth, \&xc.

\section{HORDEUM. Gen. Pl. $9^{8 .}$}

Cal. Iateralis, bivalvis, uniflorus, ternus.

muinum I. HORDEUM flofculis lateralibus mafculis ariftatis, involucris intermediis ciliatis. Sp.pl.126. (Scbeuch.

Gram. 
Gram.p. 14. bene. Moris. Hift. S. 8. t.6.f. 4. ir imo.dextram. छ ejus var. $\beta$. Vaill. Paris. $t$. I $7 . f$. 6. benì.)

Wall Barley. Anglis.

On walls and by way fides. $\odot$. VI.VIIl.

\section{TRITICUM. Gen. Pl. 99 .}

Cal. bivalvis, folitarius, fubtriflorus. Flos obtufufculus, acutus.

junceum I. TRITICUM calycibus quinqueforis truncatis; foliis involutis. Sp.pl.128. (Pluk. Pbyt.t.33.f. 4. a.)

Sea Wheat-Grafs. Anglis.

On the fea coafts in fandy places frequent, as in the ine of Bute, on the Weitern coaft of Contire, and in the inands of Orainjay, and Icolumb-kill abundantly. 24. VII.

repens 2. T. calycibus quadrifloris fubulatis acuminatis, foliis planif. Syft. Nat.p. 102. Sp.pl. 12S. (Moris. Hijt. Ox. .. 8. t. I.f. 8. in imo.)

Dog's-Grafs, or Couch-Grafs. Anglis.

In hedges and corn-fields. 2. VII.

The roots of this grafs are efteem'd to be diuretic and refolvent; and have been recommended by the great Boerbave in fcirhofities of the liver.

maritimum

3.

TRITICUM calycibus fexforis, flofculis fecundis apice ariftatis. Lin. Mantifs. p. 325. Sp. pl. I 28. Poa lo'iccza. Hudf. Fl. Ang. 35. (Pluk. phyt. t. 32.f. 7. Moris. J. 8. t. 2.f. 6. ordine 2. do.) Sea Wheat-Grafs. Anghis. 


\section{TRIANDRIA DIGYNIA:}

On the fandy fea fhore upon the Weftern coaft of Cantire. $\odot$. VI.

The ftalks are about four or five inches high, firm and ftiff: the fpiculæ grow feflile and alternate, and in all the fpecimens I have ever feen, without beards, exactly agreeable to Plukenet's figure. I ftrongly fufpect it to be only a variety of the Poa rigida I.in. Sp. pl. ror. Moris. Hift. $\int$ 8.t. 2.f. 9. EV Vail. Paris. t. I8.f. 4. occafioned by the fea water.

\section{T R I G Y N I A.}

MONTIA. Gen. Pl. ror.

Cal. diphyllus. Cor. 1. petala, irregularis. Caps. I. locularis, 3 -valvis.

fourt:na I. MONTIA. Sp.pl. I 19. (Oed. Dan. t. Iz1. Mich. Gen. 18. t. 13.f. 2. Pluk. pbyt. t. 7. f. 5. Vail: Paris. t. 3.f. 4. opt. Pet. berb. t. 10.f. 12.)

Blinking Clickweed. Anglis.

By the fides of fprings and rivulets frequent. $\odot . V$. 
C $\quad L \quad A \quad S \quad S \quad I \quad S$ IV.

T E T R A N D R I A M O N O G Y N I A.

* Flores monapetali, monospermi, fuperi aggregati. DIPSACUS. Cal. communis foliaceus. Recept. conicum, paleaceum. Sem. columnaria.

SCABIOSA. Cal. communis. Recept. elevatum fubpaleaceum. Sem. coronata, involuta.

* Fl. monopetali, monocarpi, inferi.

CENTUNCULUS. Cor. rotata. Cal. 4. partitus. Caps. I. locularis, circumfciffa.

PLANTAGO. Cor. refracta. Cal. 4. partitus. Caps. 2. locularis, circumfciffa.

* Gentiana campeftris.

Fl. monopetali, monocarpi, Juperi.

SANGUISORBA. Cor. plana. Cal. 2. phyllus. Caps. 4-gona, inter calycem \& corollam.

Fl. nonopetali, dicocei, Juperi. Stellatæ. GALIUM. Cor. plana. Fruttus fubglobofi. ASPERULA. Cor. tubulofa. Frufus fubglobofi. SHERARDIA. Cor. tubulofa. Frubtus corona?us. Scm.3-dentatis. 
Fl. tetrapetali, Juperi.

CORNUS. Cal. 4-dentatus, deciduus. Drupa nucleo 2-loculari.

Fl. incompleti, inferi.

ALCHEMILLA. Cal. 8-fidus. Sem. 1. calyce inclufum.

\section{D $\quad I \quad G \quad Y \quad N \quad I \quad A$.}

APHANES Cor. nulla. Cell. 8-fidus. Sem. 28 * Gentiana campeftris.

\section{T E T R A G Y I A.}

ILEX. Cor. I-petala. Cal. 4-dentatus. Bacea 4fperma.

SAGINA. Cor. 4-petala. Cal. 4-phyllus. Caps. 4-locularis polyfperma.

POTAMOGETON. Cor. o. Cal. 4-phyllus. Sem. 4, ferfilia.

RUPPIA. Cor. o. Cal. o. Sem.4, pedicellata,

* Linum catharticum. 


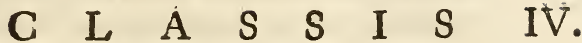

\section{T E T R A N D R I A} $M O N O G Y N I A$.

DIPSACUS. Gen. Pl. II 4 .

Cal. communis polyphyllus; proprius fuperus. Recept. paleäceumi.

fullonum 1. DIPSACUS foliis fefrilibus ferratis, paleis fructus erectis. Lin. Mantifs. 328. Sp.pl. 140. Dipsacus sylveftris. Hudf. Fl. Ang. (Ger. Em. I167.f. 2.

ter. Moris. Hift. S. 7. t. 36.f. 3.)

Wild Teafel. Anglis.

In rude uncultivated places, as at Lord Elgin's lime-works near Dunfermling, \&c. ふे. VII. VIII:

pilofus 2. D. foliis petiolatis appendiculatis. $S p . p l$. I $4 \mathrm{I}$. (Ger. Em. 1168. f. 3. malè, quia fine appendiculis.)

Small Wild Teafel, or Shepherd's-Rod. Anglis. In moift hedges and ditches, but not common. The heads of flowers in this fpecies are fpherical and white, in the preceding oval, and the flowers purple. 8 . VIII.

SCABIOSA. Gen. Pl. I I 5 .

Cal. communis polyphyllus; proprius duplex fuperus. Recept. paleaceum feu nudum.

* Corollulis quadrifidis. 


\section{TETRANDRIA MONOGYNIA.}

fuccifa I. SCABIOSA corollulis quadrifidis æqualibus, caule fimplici, ramis approximatis, foliis lanceolatoovatis integerrimis. Sp. pl. 142. (Oed. Dan. t. 279. opt. Morift. Hift. J. 6. f. I 3.f. 7. Ger. Em. 726. Sed. fol. Serratis.)

Devil's-Bit. Anglis.

In meadows and paftures. 2. VIII.

arvenfis 2. SCABIOSA corollulis quadrifidis radiantibus, caule hifpido, foliis pinnatifidis, lobis diftantibus. $S p$. pl. 143. (Oed. Dan.t. 447. opt. Moris. Hift. S. 6. t. 1 3. f. 1. Ger. Em. 719.f. 1.)

Corn-Scabious. Anglis. Gille-guirmein. Gaulis. In corn-fields frequent. 24. VIII.

* Corollulis 5-fidis.

columbaria S. corollulis quinquefidis radiantibus, foliis ratica3 . libus ovatis crenat: $S$, caulinis pinnatis fetaceis. Sp.pl. 143. (Oed. Dan.t. 314. opt. Ger. Em. 719. f. 2.)

Little Field Scabious. Anglis.

Upon dry mountainous paftures, but rare. Sibbald.

SHERARDIA. Gen. Pl. 120.

Cor. monopetala, infundibuliformis. Sem. 2, tridentata.

arvenfs 1. SHERARDIA foliis omnibus verticilla tis, fioribus terminalibus. Sp.pl. 1 49. (Oed. Dan.t. 439. opt. Barrel.ic. 54I.n. 1.)

Little Field-Madder. Anglis.

In corn fields of fandy or gravelly foil not unfrequent. $\odot$. VI-VIII. The flowers are purple.

ASPERULA. 


\section{ASPERULA. Gen. Pl. I2I.}

Cor. monopetala, infundibuliformis. Sem. 2, globofa.

-dorata I. ASPERULA foliis octonis lanceolatis, florum fafciculis pedunculatis. Sp. pl. 150. (Miller. $t$ : 55 . f. 2. Ger. Em. 1 1 24. f. I. Moris. Hift. S. g. t. 22. Jub eodem nomine.)

Woodruff. Anglis.

In woods and thady places. $4 . \mathrm{V}$.

\section{GALIUM. Gen.pl. 125 .}

Cor. monopetala, plana. Sem. 2, fubrotunda.

* Fructu glabro.

paluftre r. GALIUM foliis quaternis obovatis inæqualibus, caulibus diffufis. $S p$. pl. 153. (Oed. Dan. t. 423, opt. Pet. berb. t. 30, f. 5.)

White Ladies Bedfraw. Anglis.

On the fides of lochs and rivulets. Dr. Parfons. 4. VII.

uliginofun G. foliis fenis lanceolatis retrorfum ferrato-aculeatis 2. mucronatis, corollis fructu majoribus. $S p . p l$. 153. (Pet. berb. t. 30, f. 6.) Marfh Bedftraw. Anglis.

By river-fides and in moift meadows. 24. VII.

Galium montanum Hudf. Fl. Ang. 56, feems to be only a variety of this, growing in dry and mountainous paftures.

verum 3. G. foliis octonis linearibus fulcatis, lamis floriferis I 2 brevibus 
brevibus. sp.pl. 155. (Miller. ic. 139. f. 1. Ger. Em. 1 126. f. 1. Moris. bift. . . 9. t. 21. f. 1. Secondo ordine ad finiftram.)

Yellow Ladies Bedntraw. Anglis. Rù. Gaulis.

On dry banks and fandy fea thores abundantly. $\mathcal{4}$. VIII.

In Arran, and fome of the Weftern inands, the inhabitants make a ftrong decoction of this herb, and ufe it as a runnet to curdle milk: and in Fura, Uift, and Lewis, \&c. I was inform'd they ufeu the roots to dye a very fine red, not inferior to that from madder itfelf, but the roots are fmall.

mollugo 4. GALIUM foliis octonis ovato-linearibus fubferratis patentiffimis mucronatis, caule flaccido, ramis patentibus. Sp. pl. 155. (Oed Dan.t. 455 . opt. Ger. Em. I127.f. 4. Moris. bif. S. 9, t. 22. f. I. ordine primo.)

Great Baftard Madder. Anglis.

In hedges, and on thaded rocks by the fides of rivers, but not common. In Cartland rocks near Lanerk, \&c. 24. VIII.

$$
\text { * Fructu trifpido. }
$$

reale 5. G. foliis quaternis lanceolatis trinerviis glabris, caule erecto, feminibus trifpidis. sp. pl. ${ }_{1} 56$. (Moris. bift. S. 9. t. 22. f. 7. Pet. berb. t. 30. f. 7. Sed ambe fig. malae.)

Croffwort, or Northern-Madder. Anglis.

Upon rocks by the fides of rivers and lakes not unfrequent. 2\%. VII. 


\section{TETRANDRIA MONOGYNIA.}

The roots of this and the preceding have the quality of dying red as well as the galium verum, but are not to be found in fufficient quantity for ufe.

aparine 6. G. foliis octonis lanceolatis carinatis fcabris retrorfum aculeatis, geniculis villofis, fructu hifpido. Sp.pl. I 57. COed. Dan. t. 495. opt. Ger. Ent. 1 122. f. 1. Moris. bift. . 9.t. 22. f. 1. ordinis fecundi ad finifiram.)

Cleavers or Goofe-grafs. Anglis.

In hedges and cultivated ground frequent. $\odot$. VI. VII.

Linnous tells us that the Swedes filtrate their milk through a quantity of the ftalks of this herb : an obfervation that may poffibly be of ufe to fuch who are deftitute of proper ftrainers fur that purpofe.

\section{PLANTAGO. Gen. Pl. 142.}

Cal. 4-fidus. Cor. 4-fida; limbo reflexo. Stamina longiffima. Caps. bilocularis, circumfcina.

major 1

Pi.ANTAGO folis ovatis glabris, fcapo tereti, fpica flolculis imbricatis. sp.pl. 163. (Oed. Dan. t. 461. opt. Ger. Em. 419.f. 1.)

Great Plantain. Anglis. Cuach-Phàdruic. Gaulis. In paftures and by way-fides. 4. VI. VII.

media 2. P. foliis ovato-lanceolatis pubefcentibus, fpica cylindrica, fcapo tereti. Sp. pl. 163. (Ger. Ein. 4 19.f. 2. Moris: bift. (. 8.t. 15.f. 6.) 
118

\section{TETRANDRIA MONOGYNIA.}

Hoary Plantain. Anglis.

In paftures of a gravelly foil, but not common. Sibbald. 24. VI. VII.

lenceclata 3 P. foliis lanceolatis, fpica fubovata nuda, fcapo angulato. Sp.pl. 164. (Oed. Dan. t. 437. Ger. Em. 422. $f$. . 1.)

Ribwort Plantain. Anglis. Slàn-lus. Gaulis. In meadows and paftures common. 2 . VII.

There is a dwarfifh variety of this, with a globular tpike, growing fometimes in barren and rocky places, which feems to be the Plantago montana Hudf. Fl. Angl. 53 .

maritima $4 \mathrm{P}$. foliis femicylindraceìs integerrimis, bafi lanatis; fcapo tereti. Sp.pll. 165. (Oed.Dan. t. 243.opt.) Sea Plantain. Anglis.

It grows not only by the fea hores, but even to the fummits of the higheft mountains in the highlands: the antheræ are conftantly yellow. 24. VII.

coronopus 5 PLANTAGO foliis linearibus dentatis, fcapo tereti. Sp. pl. 166. (Oed. Dan. t. 272. opt. Ger. Einac. 427.f. 1. Morift. hift. f. 8. t. 17.f. 31.) Buckfhorn Plantain. Anglis.

In gravelly foils not unfrequent, and often upon the fea coaft. $\odot$. VII.

CEN'TUNCULUS. Gen. Pl. 145 .

Cal. 4-fidus. Cor. 4-fida, patens. Stam. brevia. Caps, 1-locularis, circumfciffa. 


\section{TETRANDRIA MONOGYNIA.}

minimus I. CENTUNCULUS. $s p \cdot p l$. 169. (Oed. Dan. $t$.

177. opt. Vail. Paris. t. 4.f. 2.)

Baftard Pimpernel. Anglis.

In gravelly places that are a litttle moift, but not common. Dr. Parfons. $\odot$. VII.

\section{SANGUISORBA. Gen. Pl. ${ }_{4} 6$.}

Cal. 2-phyllus. Germen inter calycem corollamque. officinalis I. SANGUISORBA fpicis ovatis. Sp. pl. 169. (Oed. Den.f. 97.opt. Moris. bift. S. s. t. 18.f.7. Ger. Em. 1045.f. 2.)

Great Wild Burnet. Ainglis.

In low moift meadows near Dumfries, \&c. but not common. 4. VI. VII.

\section{CORNUS. Gen. Pl. 149.}

Involucrum 4-phyllum fæpius. Petale fupera quatuor. Drupa nucleo biloculari.

Juecica I. CORNUS herbacea ramis binis. Sp).pl. ipi. (Oed. Dan. t. 5. opt. Flor. Lap. t. 5.f. 3. E fg. noft. Dwarf Honeyfuckle. Angis.

Lus-a-chraois. Gaulis. i. e. Plant-of-Gluttony.

In moorifh places by rivulets on the fides of the highland mountains not unfrequent, in Atbol, about Locb-Rannoch, on Ben-mor and Cbealleach in Breadalbane, and in Ro/s-fbire on the mountains about Locb-Broom, \&c. 24. VI. VII.

This elegant plant is about fix inches high: the leaves grow oppofite to each other, oval, fmooth, feffile, and ribb'd with five nerves: the involucrum of the flower confifts of four white leaves refembling 
refembling the petals of a corolla, in the centre of which grow twenty or more fmall blackifh tetrapetalous flowers, fupported by fhort peduncles: thefe are fucceeded by a clufter of red berries when ripe; in each of which is a heartIhap'd kernel, having two cells. The berries have a fweet waterifh tafte, and are fuppofed by the highlanders to create a great appetite, whence the Erfe name of the plant. Mr. Stuart.

ALCHEMILLA. Gen. Pl. 165.

Cal. 8-fidus. Cor. o. Semen unicum.

vu'garis I. ALCHEMILLA foliis lobatis. Sp.pl. 178. (Moris. bift. . 2.t. 20.f. 1. in imo. Milier. icon. p. I8. E? Far. minor. foliis pubejcentibus. Pluk. t. 240.f. 2) Ladies Mantle. Anglis. Copan-an-driuc, Cotaprearach-nion-an Ri. Gaulis.

In dry paftures and on the fides of mountains abundantly. 4. V-VIII.

slpina 2. AI.CHEMIILA foliis digitatis ferratis. $s p . p l$. I79. (Oed. Dan. t. 49. opt. Pet. berb. t. 9.f. I I. Mcris. hift. S. 2. t. 2o.f. 3. Sed malè quippè folic non apice ferrata.)

Cinquefoil Ladies-Mantle. Anglis.

Upon all the mountains in the highlands abundantly, even on their very fummits : one of the moft aerial plants of $N$. Britain. The leaves are generally divided into feven lobes, ferrated at the extremities, and of a beautiful white fattin color underneath. 


\section{D $\quad I \quad G \quad Y \quad N \quad I \quad A$.}

APHANES. Gen. Pl. 166.

Cal. 8-fidus, Cor. o. Sem. 2, nuda. arvenfis s: APHANES. Sp.pl. 179. (Moris. bift. f. 2. t. 20.

f. 4. in imo. Pct. berb. t. ๑.f. 12. Col. Ecploras. t. 146, bené. Ger. Em. p. 1594.f. I.)

Parfley-Piert. Anglis.

In corn fields and gravelly foils frequent. $\odot . \mathrm{V}$.

$$
\begin{gathered}
\text { T E T R A Y N I A. } \\
\text { ILEX. Gen. Pl. I } 72 .
\end{gathered}
$$

Cal.4-dentatus. Cor. rotata. Stylus. o. Bacca 4fperma.

aquifolium ILEX foliis ovatis acutis fpinofis. sp. pl. 18r. (Oed. I.

Dan. 508. Miller. icon. 46. bené. Ger. Em. 1338) Holly-Tree. Anglis. An cuil-fhionn. Gaulis. In woods and hedges.

POTOMOGETON. Gen. Pl. 174 .

Cal. o. Petala 4. Stylus o. Sem. 4 .

ratans 1. POTOMOGETON foliis oblongo-ovatis petiolatis natantibus. Sp.pl. 182. (Ger. Em.821.f. I) Broad-leav'd Pondweed. Anglis.

In lakes and ftill waterers frequent. 4. VII.

perfoliatum

P. foliis cordatis amplexicaulibus. Sp. pl. 182. (Oed.

Don.t. 126. opt. Ger. Em. 822.f. 3.)

Perfoliated Pondweed. Anglis.

In rivers and lakes. 4 . VII.

The 
The leaves are of a thin delicate texture, a fine green color, and tranfparent like a piece of oil'd paper.

denfum 3. POTOMOGETON foliis ovatis acuminatis oppofitis confertic, caulibus dichotomis, fpica quadriflora. Sp. pl. 182. (Ger. Em. 823,f. 3)

Leffer Water Caltrops, or Frog's-Lettuce. Anglis.

In ditches and rivulets: in the ditch on the right hand of the walk going down the meadows near Edinburgh. Dr. Parfons 24. VI.

The leaves at the tops of the branches are crouded clofe together, and not ferrated on the edges: the footfalks of the flowers rife out at the divifion of the ftalks, and are very thort and reAlex'd.

lucens 4. P. foliis lanceolatis planis in petiolos definentibus. Sp.pl. I8.3. (Oed. Dan. 195. opt. Pet. berb. t. 5 . f. 5.)

Long-leav'd Pondweed. Anglis.

In rivers and lakes frequent, as in Dudifton-Loch, near Edinburgh, \&xc. Dr. Parfons. 2. VII.

cripum 5. P. foliis lanceolatis alternis undulatis ferratis. Sp. pl. 183. (Ger. Em. 824.f. 2. Pet. berb. t. 5.f. g) Curled Pondweed, or Greater Water Caltrops. Anglis.

In ditches and ponds frequent. 4 . VI.

The ftalk of this kind is greatly comprefs'd, and varies with alternate and oppofite leaves, fo that the 
the P. Serratum. Lin. Sp. pl. is probably only a variety of this fpecies.

comprefum 6.

\section{gramineum}

7.

P. foliis linearibus obcufis, caule compreffo. $S p . p l$. 183. (Oed. Dan. t. 203.opt. Pet. berb.t. 5. f. 10) Flat-Italked Pondweed. Anglis.

In ditches and ftagnant waters, but not common. 4. VII.

The leaves are four or five times longer than the Stipula. The fpike produces about fix fmall flowers.

POTOMOGETON foliis lineari-lanceolatis alternis feffilibus ftipula latioribus. Sp. pl i84. (Oed. Dan. t. 222. opt. Raj. Jyn.p. 150. t. 4.f. 3. Sed non benè quoniam fine Stipulis; quadrat meliùs ad P. compreffum in multif. Loef. PrufJ.p. 206. No. 66.).

Grafs-ieav'd Pondweed. Anglis.

In ditches and ponds not very common. 24. VIII. The ftalks of this are round and nender, the leaves feffile and pointed, and about twice the length of the ftipulæ, which are much larger in this than the preceding: the fpike has fifteen or twenty flowers.

pectinatum $\mathrm{P}$. foliis fetaceis parallelis approximatis diftichis. 8. Sp. pl. 183. (Ger. Em. 828. f. 4. pet. berb. t. 5 . f. 13.)

Fennel-leav'd Pondweed. Anglis.

In rivers and lakes. Dr. Parfons. 24. VII. 


\section{TETRANDRIA TETRAGYNIA.}

puffllam g. P. foliis linearibus oppofitis alternifq; diftinctis bafi patentibus, caule tereti. Sp. pl. 184. (Loes. Pruf: 206. t.67. Pet. berb. t. 5.f. II.)

Small Grafs-leav'd Pondweed. Anglis. In ditches and ftagnant waters. $\psi$. VIII.

*arinum 1o P. foliis linearibus alternis diftinctis, infernè vaginantibus. Sp. pl. 184. (Oed. Dan. to 186. opt. Vail. Paris. t. 32. f. 5 ?)

Sea Pondweed. Anglis.

In ditches and ftagnant waters by the fea-fide not uncommon. 24. VIII.

The ftipula in th.s fpecies are a little bifid at top, and the leaves rife from the ends of them : in the other kinds the ftipulæ are diftinet from the leaves.

\section{RUPPIA. Gen. pl. 175.}

Cal. o. Cor. o. Sem. 4-pedicellata.

meritima I. RUPPIA. Sp. pl. 184. (Oed. Dan. t. 364. opt. Micbel. Gen. 72. t. 35. Pluk. phyt. 248. f. 4. Pet. herb. t. 6. f. 1.)

Sea Ruppia. Anglis.

In ftagnant waters by the fea fide not uncommon, as at Glen-Elg, in Invernefspire, \&c. 24. VIII.

It has the habit of ${ }_{A}^{a}$ potomogeton, but may readily be diftinguinhed by it's little umbel of oval feeds ftanding fingly on footftalks.

\section{SAGINA. Gen. $p l . x 76$.}

Cal. 4-phyllus. Petala 4. Caps. 1-locularis, 4-valvis, polyfperma. 
procumbens SAGINA ramis procumbentibus. Sp.pl. 185. (Pet.

I. berb. t. 59, f. 10. Seguier Veronens. $421 . t .5 . f$. 3. melir. Pluk. pbyt.t. 74.f. 2.)

Pearlwort. Anglis.

In fandy and gravelly foils frequent. $\odot$. VI.

It varies, fometimes without petals, and fometimes with a fifth part added to the whole fructification.

erecta 2. S. caule erecto fubunifloro. Syft. Nat. p. I3I. Sp. pl. 185. (Raj. Jyn. p. 348. t. 15. f. 4. Vail. Paris. t. 3.f. 2. Pet.berb. t. 59.f. 9. malè.)

Little Upright Stichwort. Anglis.

In paftures of a gravelly foil. Dr. Parfons. ๑. V. 


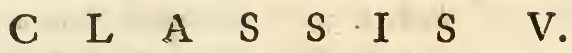 \\ P E N T A N D R I A M O N O G Y N I A.}

* Flores monopetali, inferi, tetrafpermi. Afperifoliæ. ECHIUM. Cor. fauce nuda, irregularis ! campanulata.

PULMONARIA. Cor. fauce nuda, infundibuliformis; Cal. prifmaticus.

LITHOSPERMUM. Cor. fauce nuda, infundibuliformis. Cal. quinquepartitus.

SYMPHYTUM. Cor, fauce dentata, ventricofa, LYCOPSIS. Cor. fauce fornicata, infundibuliform. tubo curvato.

ASPERUGO. Cor. fauce fornicata, infundibulif. Frultus compreffus.

CYNOGLOSSUM. Cor. fauce fornicata, infundibulif. Sem. depreffa, latere affixa,

ANCHUSA. Cor fauce fornicata, infundibulif. tubo bafi primatico.

MYOSOTIS. Cor. fauce fornicata, hypocrateriform. lobis emarginatis.

* Flores monopetali, inferi, angiojpermi.

ANAGALLIS. Caps. 1-locularis, circumfiffa. Cor. rotata. Stigm. capitatum. 


\section{PENTANDRIA MONOGYNIA.}

LYSIMACHIA. Caps. r-locularis, ro-valvis. Cor. rotata. Stigma obtufum.

PRIMÚLA, Caps. I-locularis. Cor. infundibuliformis, fauce pervia. Stigm. globofum.

MENYANTHES. Coфs. I-locularis. Cor. villofa! Stigma bifidum.

CONVOLVULUS. Caps. bilocularis, 2-fperma. Cor, campanulata. Stigm. bifidum.

HYOSCYAMUS. Caps. bilocularis, operculata! Cor. infundibulif. Stigm. capitatum.

VERBASCUM. Caps. bilocularis. Cor. rotata. Stigma obtufum. Stam declinata.

AZALEA. Caps. 5. locularis. Cor. campanulata. Stigma obtufum.

VINCA. Folliculi duo erecti. Cor. hypocrateriformis. Sem. fimplicia.

SOLANUM Bacca bilocularis. Antberce biperforatæ!

ATROPA. Bacca bilocularis. Stam. diftantia, incurvata,

$$
\text { * Flores monopetali, fuperi. }
$$

SAMOLUS. Caps. I-locularis apice 5-valvis. Cor. hypocrater. Stigma capitatum.

CAMPANULA. Caps. 3-s. 5-locularis perforata. Cor. campanulata Stigma trifidum.

LONICERA. Bacca bilocularis fubrotunda. Cor. inæqualis. Stigm. capitatum. 
* Flores pentapetali, inferi.

EVONYMUS. Bacca capfularis, lobata. Cal. patens. Sem. baccato-arillata.

* Flores pentapetali, Juperi.

RIBES. Bacca polyfperma. Cal. corollifer. Stylus bifidus.

HEDERA. Bacca 5-fperma. Cal. cingens fructum. Stigma fimplex.

* Flores incompleti, inferi.

GLAUX. Caps. 5-fperma 5-valvis. Cal. fimplex, rudior, campanulatus.

* Polygonumi ampbibium.

D $\quad I \quad G \quad Y \quad N \quad I \quad A$.

* Flores monopetali, inferi.

GENTIANA. Caps. I.locularis, bivalvis. Cor. tubulofa, indeterminata.

* Flores incompleti.

SAISOLA. Sem. 1. cochleatum, tectum. Cal. 5phyllus.

CHENOPODIUM. Sem. I. orbiculare. Cal. 5phyllus, foliolis concavis.

BETA. Sem. I. reniforme. Cal. 5-phyllus, bafi femen fovens.

ULMUS. Bacca exfucca, compreffa. Cal. I-phyllus, emarcefcens. 
* Flores pentapetali, Juperi, difpermi. Umbellatæ. A. Involucro univerfali partialiq;

ERYNGIUM. Flores capitati. Receptac. paleaceum.

HYDROCOTYL, Flor. fubumbellati, fertiles. Sem. compreffa.

SANICULA. Flor. fubumbellati, abortivi. Sem. muricata.

HERACLEUM. Fior. radiati; abortivi. Involucrum deciduum. Sem. membranacea.

OENANTHE. Flor. radiati, abortivi radio. Invol. finplex. Sem. coronata, feffilia.

CAUCALIS. Flor. radiati, abortivi. Involucr. fimplex. Sem. muricata.

DAUCUS. Flores radiati, abortivi. Invol. pinnatum. Sem. hifpicla.

TORDYLIUM. Flor. radiati, fertiles. Invol. fimplex. Sem. margine crenata.

CONIUM. Flor. flofculofi, fertiles. Pet. cordata. Sem. gibba, coftato-fulcata. Tnvolucella dinidiata. BUNIUM. Flor. Hofcul. fertiles. Pet. cordata. Involucella fetacea.

ATHAMANTA. Fior. flofcul. fertiles. Pet. cor data. Sem. convexa, Atriata.

SIUM. Flor. flofcul. fertiles. Pet. cordata. Sem. fubovata, friata.

CRITHMUM. Flor. floful. feitiles, Pct. planiurmla. Invelacrunz horizontale. 
LIGUSTICUM. Flor. flofculos. fertiles. Pet. involuta. Invol. membra:acea.

ANGELICA. Flor. flofculos. fertiles. Pet. planiufcula. Uimbellule globofx.

SISON. Flor. flofcul. fertiles. Pet. planiufcula. Umbel. depauperata.

B. Involucris partialibus; univerfali nullo. ETHUSA. Flor. fubradiati fertiles. Involucella dimidiata.

SCANDIX. Flor radiati abortivi. Fruçus obiongi.

CHAROPHYLLUM. Fior. flofcul. abortivi. Iniol. 5-phylla.

PHELLANDRIUM. Flor. flofcul. fertiles. Frütus coronati.

IMFERATORIA. Flor. flofculofi fertiles. Umbel. expanfo-plana.

CICUTA. Flor. flofculof, fertiles. Pet. planiufcula.

C. Involucró nullo; nec univerfali, nec partialibus. SMYRNIUM. Flor. flofculi abortivi. Seri. reniformia angulata.

CARUM. Flor. flofcul. abortivi. Sem. gibba, ftriata. EGOPODIUM. Flor. fiofcul. fertiles. ¿em. gibba. ftriata. Pet. cordata.

APIUM. Flor. flofculos. fertiles. Sen. minuta, ftriata. Pet. inflexa.

PIMPINELIA. Flor. Alofculos. fertiles. (Umbelle ante florescentian mutcntes) Pet. cordata. 


$$
\text { T R I G } \mathrm{Y} \quad \mathrm{N} \text { I A. }
$$

VIBURNUM: Cor. 5 -fida. Bacca I-fperma. SAMBUCUS. Cor. 5-fida. Bacca 3-fperma.

$$
\text { * Flores inferi. }
$$

ALSINE. Cor. 5-petala. Cap̧s. I-locularis, Cal. 5-phyllus. Pit. bifida.

$$
\text { T E T R A G Y N I A. }
$$

PARNASSIA. Cor. 5-petaia. Caps. 4-valvis. Necior, 5, ciliato-glandulofa.

$$
\text { P E N T A G Y N I A. }
$$

LINUM. Cor. 5-petala. Caps. 10-locularis, 2fperma.

DROSERA. Cor. 5-petala. Caps. I-locularis; apice dehifcens.

SíBBALDIA: Corr. 5-petala. Seriz. 5. Cal. 10fidus.

STATICE. Cor. 5-partita. Sem. I, calyce infundibuliformi veftitum.

$$
\text { P O L Y G Y N I A. }
$$

MYOSURUS. Cal. 5-phyllus. NeEtar. 5, lingulatd. Senz. numerofa.

Raniniculus bederaceus. 


\section{$M O N O G$ Y N I A.}

MYOSOTIS. Gen. pl. 180.

Cor. hypocrateriformis, 5 -fida, emarginata; fauce claufa fornicibus.

Scorpioides 1.

MYOSOTIS feminibus nudis, foliorum apicibus callofis. Sp.pl. 188. Ger. En 337.f. 4. Morif. bift. Ox. f. п. t. 3 !. $f$. г. ordine fecundo. \& ejus var. latioribus foliis Raj. Syn p. 229 t. 9.f. 2. \& altera varietas paluftris foliis glabris. Ger. Em. 33\%.f. 3. Moris. bift. S. 1 1. t. 31.f. 4. ordine secundo.)

Moufe ear Scorpion-Grafs. Anglis.

The hairy kind is frequent in dry corn fields; and a leffer variety, with fmall yellow flowers, I obferv'd upon walls near Drumlanrig. The finoothleav'd marth kind is common on the Sides of rivulets and lakes. 24. V.VIII.

LITHOSPERMUM. Gen. pl. $18 \mathrm{I}$.

Cor. infundibuliformis, fauce perforata, nuda. Cal. 5-partitus.

officinale 1. LITHOSPERMUM feminibus lavibus, corollis vix calycem fuperantibus, foliis lancèolatis. 'p. pl. 189 . (Moriff. bif.. S. 11. t. 31. f. 1. crdine primc. Ger. Em 609. $f$. 2.)

Gromill, Gromwell, or Graymill. Anglis.

In wate uncultivated plares, as near the monaftery of Ecoulicu, at Invernes, and under the Weft fide of salifury-Craigs, and at ligfin. Dr. Por. fons. 24. VI. 
arvenfe 2 . L. feminibus rugofis, corolla vix calycem fuperantibus. ip. pl. 190. (Oed. Dan. t. 456. opt. Ger. 4m.610.f.4.)

Baftard Alkanet. Anglis.

In corn fields not uncommon. Dr. Parfons. ๑. Ví. Linnaus informs us that the country girls in Sweden paint their faces with the roots.

\section{ANCHUSA. Ger. Pl. $18_{2}$.}

Cor. infundibuliformis, fauce claufa fornicibus. Semir. bafi infculpta.

Sempervi- ANCHESA pedunculis diphyllis capitatis. $s p . p l$. rens i.

$$
\text { 192. (Moris. bift. Ox. f. 11.t. 26.f. 2.) }
$$

Evergreen Alkanet. Anglis.

In the Glen at Dungla/s. Dr. Parfons. 4. V. VI.

\section{CYNOGLOSSUM. Gen. pl. 183.}

Cor. infundibuliformis, fauce claufa fornicibus. Semina depreffa, interiore tantum latere Stylo affixa.

offinale I. CYNOGLOSSUM ftaminibus corclla brevioribus, foliis lato-lanceolatis tomentofis feffilibus. $s p \cdot p l$. 192. (Ger. Em. 804. f. I. Moris. bift. J. I 1. t. 30. f. I.)

Hound's-Tongue. Anglis.

In wafte places nèar towns and villages, as about Burntifland and Kinglorm, and at the foot of the hill of Kinnoul, near Perth, \&cc. o. VI. VII. No quadruped except the goat will eat it.

$$
\text { PULMONARIA. Gen.pl. } 184 .
$$

Cor. infundibuliformis fauce pervia. Cal. prifmatico-pentagonus. 
maritima I. PULMONARIA calycibus abbreviatis, foliis ovatis, caule ramofo procumbente. Sp.pl. 195. (Oed. Dan. t. 25. Dillen. Hogl. Eltbam. t. $65 . \mathrm{f} \cdot 75$. benè. Moris. bift. S. II. t. 28. f. I2. ordine $\int_{e-}$ cundo.) Fon to t7\%

Sea Buglofs. Anglis.

Upon the fea coant not unfrequent, growing out of ftony beaches which feem incapable of affording vegetation; as on the coaft of Fif.e, near St. Andrew's, \&xc. in the ille of Bute, upon a fandy Shore, in Arrain at Locb-RinSa, and at Lam!afh, at Icoiumb-kill, and at Glen-Elg, in Invernefsfioire, \&cc. 24. VII. VIII.

It is one of the molt beautiful indigenous plants of Great-Britain. Its undulated glaucous leaves contrafted with red and blue flowers, are extremely ornamental to the barren fhores where it grows, and readily difcover the plant to any cusious obferver.

\section{SYMPHYTUM. Gen. Pl. 185 .}

Cor. limbus tubulato-ventricofus; fauce claufa radiis fubulatis.

of cinale $\mathrm{x}$. SYMPHYTUM foliis ovato-lanceolatis decurrentibus. Sp.pl. 195. (Ger. Em. 806.f. 1. Moris. bift. f. I1. $t$ 29.f. 1. ordine fuperiare.)

Comfrey. Anglis.

By the fides of rivers and ditches, as on the banks of the water of Leith, oppofite St. Bernard'sWell, and in Coryzon woods, \&c. Dr. Parfons. 24. V. 


It varies with purple or yellow flowers, with thick branched roots, and fometimes with tuberous or knobbed ones.

ASPERUGO. Gen. Pl. $18 \mathrm{~g}$.

Cal. fructus compreffus ; lamellis plano parallelis, finuatis.

procumbens ASPERUGO calycibus fructus compreflis. $s p \cdot \hat{p} l$. 1.

198. Ger. En̈r. 1122. f. 2. Morift. bift. S. I1.t. 26. $f .13$.

Small Wild Buglofs, or German Madwort. Anglis. In wafte places, but not common. By the church at Dunbar. Dr. Parfons. ๑. V.

The leaves are oval and aiternate at the bafe, but tiro or four together at the top, and fo rough that they adisere to the cloaths more readily than Goofe-grals: the flowers are violet-color'd, and forcely larger than the calyx.

\section{LYCOPSIS. Gen. Pl. 190.}

Corolla tubo incurvato.

arenfis I. LYCOPSIS foliis lanceolatis hifpidis, calycibus florefcent.bus erectis. Sp.pl. 199. (Oed. Dan.t. 435. opt. Moris. lijt. S. 11. t. 26.f. 8.Gcr. Em. ;99.f. 3.)

Small Wild Buglofs. Anglïs.

In corn fields common. $\odot$. VII.

The plant is corered all over with bulbous hairs.

\section{ECHIUM. Gen. pl. 19 I.}

Cor. irregularis, fauce nuda. 
vulgare I. ECHIUM caule tuberculato-hifpido, foliis caulinis lanceolatis hifpidis, floribus fpicatis lateralibus. sp. pl. 200. (Oed. Den. t. 445. opt. Ger. Em. 802.f. 2.)

Vipers-Buglofs. Anglis.

In corn-fields and by way-fides not unfrequent, as about Kirkcaldy and Kingborn, and at CharlesTown, Lord Elgin's lime-works, and under $A r$ thur's-ieat, \&xc. ò. VII. VIII.

About Mellross-Abbey, and fome other places, I obferv'd what I apprehend to be only a variety of this; it differs chietly in having the branches more divaricated, and the ftamina nearly twice as long as the flower. Perhaps this is the Echium anglicum Hudf. Fl. Ang. p. 70.

\section{PRIMUI,A. Gen. Pl. 19'7.}

Involucrum umbellulx. Corolle tubus cylindricus, ore patulo.

veris 1. PRIMULA foliis dentatis rugofis. $S p . p l .204$. I. var. a. officinalis. (Oed. Dan. t. 433. Ger. Em. $780 . f$ I.)

2. var. 3. elatior. (Oed Dan. t. 434. Ger. Em. 780. f. 2.)

3. var. $\gamma$. acaulis. (Oed. Dan. t. 19) 4 . Ger. Em. 78 s. f. 5.)

a. Cownips. $\beta$. Oxlips, $\gamma$. Primrofe. Anglis. Sograch. Gaulis.

In meadows, paftures and woods frequent. $4 . \mathrm{V}$. The fegments of the flowers within, near the bafe, are mark'd with red or faffron-color'd fpots, which 


\section{PENTANDRIA MONCGYNIA.}

which our poet Sbakespeare prettily fuppofes to be the gifts of the fairy-queend, and to be the fource of their fiweet odors. He thus introduces a fairy fpeaking :

And I ferve the fairy-queen,

To dew her orbs upon the green;

The cownips tall her penfioners be,

In their gold coats fpots you fie;

Thole be rubies, Fairy favours,

In thofe freckles live their favcurs:

I muft go feek fome dew-drops liere and there, And hang a pearl in every cownip's ear. Midjummer Nigbi's Dream, AEZ 2, sc. 1.

farinofa 2. PRIMULA foliis crenatis glabris, forum limbo plano. Sp. pl. 205. (Ocd. Dant. t. I 25. opt. Ger. Em. $7^{8} 3 \cdot f .1 .2$. Moirs. bift. f. 5.t. 24.f. $i_{-}$) Bird's-Eye. Anglis.

In wet mountainous paitures, but not very common. 4. VI.

The leaves and calyces are cover'd with a mealinefs like our garden auricula: the Howers are of a bright red. It is a very elegant little plant, and worthy of a place in the flower garden.

\section{MENYANTHES. Gen. Pl. 202.}

Corolla hirfuta. Stigme bifidum. Caps. I-locularis. inifoliata 1. MENYANTHES foliis ternatis. Sp.pl. 208. (Moris. hift. . 15.t.2. f. prima ad finifram ordine fecundo. Ger. Em. I 194. abjq; fioribus.) Marfh Trefoil or Bog bean. Anglis. 


\section{PENTANDRIA MONOGYNIA.}

In marthes and lakes frequent. 4. V. VI.

An tri-bhileach, lui'-nan-tri-beann. Gaulis.

The flowers of this plant are fo extremely beantiful, that nothing but its native foil could exclude it from a place in every garden. They grow in an elegant fpike; are white, dafh'd with pink, and fring'd internally with hairs.

\section{LYSIMACHIA. Gen. Pl. 205.}

Cor. rotata. Caps. globofa, mucronata, so-valvis. * Pedunculis multiforis.

euigaris 1. LYSIMACHIA paniculata, racemis terminalibus. Sp.pl. 209. (Ger. Em. 474.f. 1.) Yelpw Willow-herb, or Loofeftrife. Anglis.

On the fides of rivers and lakes, but not very common. I obferv'd it by the fides of lochs in the ifland of Mull, \&c. 24. VII.

\section{** Pedunculis unifloris.}

sszorum 2. L. fuliis ovatis acutis, foribus folitariis, caule procumbente. Sp.pl. 211. (Oed. Dan. t. 174. opt. Moris. hift. $.5 . t$. 26. f. 5. ordine Secundo. Ger. Em. 618.f. 4.)

Yellow Pimpernell of the Woods. Anglis. In woods and thady places frequent. 4 . VI.

Humalcria L. folis fubcordatis, foribus folitariis, caule re3 . pente. Sp. pl. 2 11. (Oed. Dan.t. 493. opt. Moris. kift. S. 5. t. 26.f. 1. ordine primo. Ger. Em. 630. f. т.)

Moneywort. Anglis. 


\section{PENTANDRIA MONOGYNIA.}

In low wet meadows by the fides of ditches, but nat common. 4 . VI.

\section{ANAGALIIS. Gen. Fl. 206.}

Cor. rotata. Copps. c.rcumfcifia.

arvenfis I. ANAGALLIS foliis indivifis, caule procumbente. Sp.pl. 211. (Oed. Dan. 88. opt. Moris. hift. S. 5 . t. 26. f. I E 2. ordine Secundo. Ger. Em. G1, f. 1 \& 2.)

Common Pimpernel. Anglis.

In corn-fields common. $\odot$. V-VIII.

It varies with fcarlet and blue flowers, which open at eight o'clock in the morning, and clote about noon. Small birds are very fond of the feeds of this plant.

tenella 2. ANAGALLIS foliis ovatis acutiufculis, caule repente. vid. Lin. Mantif. p. 335. Lyfimachia tenella. Sp. pl. 2 1 . (Moris. kijt. J. $5 . t .26$ f. 2. ardine primo. Ger. Em. 630. $f \cdot 3$.

Creeping Pimpernel, or Purpje Moneywort. Anglis. In bogs not uncommon. 24. VII. VIII.

The filaments are hairy, and the capfule fplits horizontally into two hemilpheres; it therefore properly belongs to this genus.

\section{AZALEA. Gen. Pl. 212.}

Cor. campanulata. Stcin. receptaculo inferta. Caps. 5-locularis.

procumbers AZALEA ramis diffufo-procumbentibus. $S p \cdot p l$. I.

215. (Oed. Deis. t. 9. Flor. Lap. t. 6.f. 2.) Trailing Thyme leav'd Azalea. Anglis. 
Upon dry barren ground near the fummits of the highland mountains in many places, as on Benmor, in Breadalbane, Ben-Croacban, in Argylefire, Ben-na Scree, and other high mountains about Locb-Urn in Inverness-jhire, and fparingly upon Ben-Lomond, \&c.

The flowers are of a bright red color. $h$. VI.

\section{CONVOLVULUS. Gen. Pl. 215.}

Cor campanulata, plicata. Stigm. 2. Caps. bilocularis, loculis difpermis.

* Caule volubili.

arvenfis I. CONVOLVULUS foliis fagittatis utring; acutis, pedunculis fubunifloris. ip pl. 218. (Oed. Dan. t. 459. opt. Mor. bift. S. 1. t. 3.f. 9. Ger. Em. s6r.f. 2.j

Small Bindweed. Anglis.

In corn-fields frequent. 24 . VII.

Sepium 2. C. foliis fagittatis pontice truncatis, pedunculis tetra* gonis unifloris. $s_{p}$. pl. 2 , s. (Oed. Dan. 458.opt. Moris. bift. .. I. t. 3.f. 6. Ger. Em. 86 I. I.) Great Bindweed. Anglis.

In wet hedges, but not common : obferv'd by Dr. Parfons near Dumbarton.

$\because$ Caule protrato.

foldanelia 3 CONVOLVULUS foliis reniformibus pedunculis unifloris. Sp. pl. 226. (Moris. bift. f. 1. t. 3. f. 2 Ger. Em. 838. f. x.)

Sea Bindweed. Scottifh Scurvy-Grafs. Anglis. 
On the fea fhores in fandy places frequent, as on the Weftern coaft of Cantire, between Macbrianifb and Bar, and in the inand of Oransa plentifully, \&c. Sibbald fays it grows near the Elg.

CAMPANULA. Gen. Pl. 218.

Cor. campanulata fundo claufo valvis ftaminiferis. Stigma trifidum. Caps. infera, poris lateralibus dehifcens.

* Foliis levioribus anguftioribus.

rotundifolia CAMPANULA foliis radicalibus reniformibus, I. caulinis linearibus. Sp. pl. 232. (Oed. Dan. t. 189. Ger. Em. 452.f. 3. Moris. bift. S. 5.t. 2. f. 17.)

Round-leav'd Bell-flower. Anglis.

Curachd-na-cu'aig. Gusulis.

In dry mountainous paftures frequent. 24. VIII.

Upon the hill of Moncrief, near Perth, I obferv'd a variety about two inches high, bearing a fingle flower, and having numerous linear leaves on the ftalk.

** Foliis fcabris latioribus.

latifolia 2. C. foliis ovato-lanceolatis, caule fimplicifimo tereti, floribus folitariis pedunculatis, fructious cernuis. Sp pl. 233. (Oed Dan. t. 85. optime. Ger. Em. 448.f.3. Moris. nift $f_{5} 5$ t. 3.f. 27.)

Giant Throatwort. Anglis.

By the fides of rivulets at the foot of mountains, in thady places, not unfrequent; as at CartlondRocks, near Lanerk, at Tajmouth-Hermitnre, and 
by the fide of the beautiful cafcades at Moness; near Tajmouth, \&c. 4. VII.

The leaves are ferrated, and of an oval-lanceclate form : the calyces fmooth.

trachelium CAMPANULA caule angulato, foliis petiolatis, $3 \cdot$ calycibus ciliatis, pedunculis trifidis. $S p \cdot p l .235$. (Ger. Eni. 448.f. 1. Moris. bift: . . 5.t. 3.f. 28.) Nettle-leav'd Throatwort, or Canterbury-Bells. Anglis.

In the fame kind of places as the preceding, but not common. Dr. Parfons. 4. VII.

The leaves are nearly heart. Thap'd, and indented on the edges.

glomerata 4 C. caule angulato fimplici, Aoribus feffilibus, cap1tulo terminali. Sp. pl. 235. (Ger. Em. 449. f. 4. Moris. kift. $.5 \cdot$. t. $4 \cdot f \cdot 43$.

Cluftered Throatwort, or fmall Canterbury-Bells. Anglis.

In dry mountainous paftures, but not very common. 2f. VII.

\section{SAMOLUS. Gen. Pl. 222.}

Cor. hypocrateriformis. Stamine munita fquamulis corolla Caps. I-locularis, infera.

valerandi 1 SAMOLUS. Sp.pl. 243. (Oed. Dan. t. 198. opt.

$$
\text { Ger. Em. 620.f. 3.) }
$$

Round-leav'd Water Pimpernel. Anglis.

In marfhy places, but not very frequent. I obferv'd it in the illand of Gigba, \&c. 4. VII. 


\section{LONICERA. Gen. Pl. 233.}

Cor. monopetala, irregularis. Bacca polyfperma, 2-locularis, infera.

periclyme- LONICERA capitulis ovatis imbricatis terminalinum 1. bus, foliis omnibus diftinctis. Sp. pl. 247. (Ger. Ein. $8 g$ i.f. I.)

Common Honeyfuckle; or Woodbine. Anglis. An iadh-hlait. Gaulis.

In woods and hedges, as in Coryton woods, \&c, h. VII.

\section{VERBASCUM. Gen. Pl. $245^{\circ}$}

Cor. rotata, fubinæqualis. Caps. bilocularis, 2-valvis. thapfus r. VERBASCUM foliis decurrentibus utrinque tomentofis, caule fimplici. Sp.pl. 252. (Ger. Em. 773. $f$. 1.)

Great Woolly Mullein, Hag-taper, or Cow'sLungwort. Anglis.

In dry fandy foils, between North and South Weesnss on the coaft of Fife, \&c. $\delta$. VII.

lycbnitis 2. V. follis cuneiformi-oblongis. Sp pl. 253. (Ger. Em. 775. $f \cdot 3$.)

White-flower'd Mullein. Anglis.

In the Back-Walk at Sterling, call'd Edmonfton'sWalk. o. ViI.

It was out of flower when I found it ; but thould the flowers be of a pale yellow, it is then the zar. $\beta$ of Huds. Fl. Ang. p. 76 .

HYOSCIAMUS. 


\section{HYOSCYAMUS. Gen. Pl. 247.}

Cor. infundibuliformis obtufa. Stamina inclinata.

Caps. operculata, 2-locularis.

niger 1. HYOSCYAMUS foliis amplexicaulibus finuatis, floribus feffilibus. Sp. pl. 257. (Ger. Em.t. 353 . f. I.)

Common Henbane. Anglis.

In wafte places near towns and villages. $\odot$. VI.

The whole plant is cover'd with unctuous foetid hairs: the flowers are yellow, reticulated with violet-color'd veins. The root, leaves and feed are a moft powerful narcotic : a few of the feeds have been known to deprive a man of his reafon use of fies and limbs.

\section{ATROPA. Gen. Pl. 249.}

Cor. campanulata. Stam. 'difantia. Bacca globofa, 2-locularis.

belladonna ATROPA caule herbaceo, foliis ovatis integris. 1. Sp. pl. 260. (Miller. ic. 62. benè. Ger. Em. 340. Moris. bift. . ${ }_{13}$. t. 3. f. 4.)

Deadly Nighthade. Anglis.

In the King's park at Sterling, and at Icolumbkill. 4. VII.

The berries of this plant are of a malignant poifonous nature, and, being of a fweet tafte, have frequently been deftuctive to children. A large glafs of warm vinegar, taken as foon as poffible after eating the berries, will prevent their bad effects. 


\section{SOLANUM. Gen. Pl. 251.}

Cor. rotata. Antberce fubcoalitæ, apice poro gémino dehifcentes. Bacca 2-locularis.

dulcamaras SOLANUM caule inermi frutefcente flexuofo, foliis fuperioribus haftatis, racemis cymofis. $S p$. pl. 264. (Ger. Em. 350.)

Woody Nighthade, or Bitter-fweet. Anglis.

In moint hedges, but not common. At that end of Dalkeith neareft to Edinburgh. Dr. Parjons. 4. VII.

nigrum 2. SOLANUM caule inermi herbaceo, foliis ovatis dentato-angulatis, umbellis nutantibus. $s p . p l$. 266. Oed. Dan. t. 460. opt. Ger. Em. 339. f. I. Moris. bift. S. 13. t. I. f. 1. ordine primo.)

Garden or Common Night thade. Anglis. In wafte places near towns and villages frequent. $\odot$. VII. \& VIII.

\section{EUONYMUS. Gen. Pl. $27 \mathrm{I}$.}

Cor. 5-petala. Caps. 5-gona, 5-locularis, 5-valvis, colorata. Sem. calyptrata.

curopaus 1. EUONYMUS floribus plerifque quadrifidis, foliis feffilibus. Sp.pl. 286. Eं Mantifs. 342. (Ger. Em. 1468. $f$. x.)

Spindle-Tree or Prickwood.

In woods and hedges, in many places according to sibbeld, but I found it not mỵfelf. $r$. V. 


\section{RIBES. Gen. Pl. $28 \mathrm{r}$.}

Petala quinque \& ftamina calyci inferta. Stylus bifidus. Bacca polyfperma, infera.

rubrum I. RIBES inerme racemis glabris pendulis, floribus planiufculis. Sp.pl. 290. (Ger. Em. 1593. f. I.) Red Currants. Anglis.

In the inland of Ifla, amongit the brufh-wood on the bank of the sound. 5 . V.

alpinum 2. R. inerme, racemis erectis; bracteis fore longioribus. sp. pl. 291. (Figura non exfat.)

Sweet Mountain Currants. Anglis.

In woods and out of the fiffures of rocks. Dr. Parfons. T. V.

nigrunin 3. RIPES inerme, racemis pilofis floribus oblongis. Sp.pl. 29r. (Figuram non invenio.)

Black Currants or Squinancy-Berries. Anglis.

In the wood on the bank of the Sound of $I f a$, together with the Red-Currants.

\section{HEDERA. Gen. Pl. 283 .}

Peicla 5-oblonga. Bacca 5-fperma, calyce cincta.

belix I. HEDERA foliis ovatis lobatifque. Sp. pl. 292. (Ger. Em. 857.f. I. E 2.)

Ivy. Anglis. Eidhionn-na-craige, Gaulis.

Upon rocks and trunks of trees.

GL.AUX. Gen. Pl. 2 ýr.

Cal. I-phyllus. Cor. nulla. Caps. I-locularis, 5valvis, 5-fperma. 


\section{PENTANDRIA DIGYNIA.}

maritimis I. GLAUX. sp.pl. 301. (Ger. Em. 562. Loes. PruJ. p. $13 . t .3$. melior.)

Sea Milkwort, or Black Saltwort. Anglis.

Upon the fea hores frequently, both of the continent and Weftern illes. 24. VII.

\section{VINCA. Gen. Pl. 295.}

Contorta. Folliculi 2, erecti. Seniina nuda.

winor I. VINCA caulibus procumbentibus, foliis lanceolato ovatis, floribus pedunculatis, Sp: pl. 304 . (Ger. Em. 894.f. I.)

The Leffer-Periwinckle. Anglis.

In Coryton woods. Dr. Parfons. 24. V.

\section{I $\quad G \quad Y \quad N \quad I \quad A$.}

CHENOPODIUM. Gen. Pl. 309.

Cal. 5-phyllus, 5-gonus. Cor. o. Sem. I, lenticto lare, fuperum.

* Foliis angulofis.

bonus ben- CHENOPODIUM foliis triangulari-fagittatis inricus I. tegerrimis, fpicis compofitis aphyllis axillaribus. Sp.pl. 3. 8. (Moris. bift. S. 5. t. 30. f. 1. ad dextram ordine fecundo. Ger. Em. 329. Petiv. berb. $t$. 7.f. 12.)

Englifh Mercury, Wild Spinage, or Allgood. Anglis.

In wafte places and by way-fides frequent. 24. VIII.

The young leaves in the Spring are often eaten as greens, and are very good tafted. 
urbicum 2. C. foliis triangularibus fubdentatis, racemis confertis ftrictiffmis. $S p \cdot p l .318$. (Buxb. Hallens. 69. t. I. Pét. berb. t. 8.f. 8. malè.)

Upright Goofefoot. Anglis.

In wafte places, and under walls in towns and villages. Sibbald. $\odot$. VIII.

rubrum 3. C, foliis cordato-triangularibus obtufufculis dentatis, racemis erectis compolitis fubfoliofis caule brevioribus. Sp. pl. 318. (Ger. Em. 328. f. 2 . Dalechamp. bift. 542. t. 542.)

Sharp-leav'd Goofefoot. Anglis.

On dunghills and under walls in towns and villages. Sibbald. ๑. VIII.

The ftalks fpread on the ground: the leaves are thick and fhining, and turn red before they die: the fpikes confint of feffile clufters of flowers, intermix'd with linear leaves.

murale 4. CHENOPODIUM folits ovatis nitidis dentatis acutis, racemis ramofis nudis. $S p . j l .318 .(\mathrm{Ger}$. Em. 328.f. 1. Pet. berb. t. 8.f. 5.)

Common Goofefoot, or Sowbane. Anglis.

In walte places and under walls. Eibbald. ๑. VIII. The leaves are more tharply indented than in the CHE, rubrum, and the flowers grow in branching clufters, or Corymbi, and not in fpikes.

albuin 5. C. folis rhomboideo-triangularibus erofis pofticè integris, fummis oblongis, racemis eretis. $S p$. pl. 319. (Pet. bert.t. 8.f. 2.)

Common White or Fron-Blite. Anglis. 
In corn fields and gardens very common. $\odot$. VII.

The fpikes grow erect, with thick, oval, feffile farinaceous clufters of flowers : the leaves wither away early in the Autumn, the ftalk and fpilies remaining. In Ifla I obierv'd the people boil'd and eat it as greens.

viride 6. C. foliis rhomboideis dentato-finuatis, racemis ramofis fubfoliatis. Sp.pl. 319. (Vail. Paris. $t .7$. f. I. Pet. berb. t. 8. f. 4.)

Green Blite. Anglis.

It grows as a common weed in almoit every garden. $\odot$. VII.

The ftalk is green, and much branched, with red angles at the bafe of the ramifications: the upper leaves are nearly entire, or at moft have not above one or two cients. This is eaten as well as the preceding.

bybridum 7 . CHENOPODIUM foliis cordatis angulato acuminatis, racemis ramofis nudis. Sp. pl. 319. (Vail. Paris. t. 7.f. 2. Pet. berb. t. 8.f. 7.)

Maple-leav'd Blite. Anglis.

In gardens and wafte places, but not common. $\odot$. VIII.

\section{** Foliis integris.}

vulvaria 8. C. foliis integerrimis rhomboideo-ovatis, floribus conglomeratis axillaribus. Sp. pl. $32 \mathrm{I}$. (Ger. Em. 327. Pet. berb, t. 7.f. II. Moris. hift. S. 5. t. 3 I. f. 6.)

Stinking Blite. Anglis. 
In wafte places, and under walls in or near towns, but not common. Sibbald. $\odot$. VIII.

It grows flat on the ground, and may readily be known by it's ftrong difagreeable fmell of decay'd falt-fint?.

polygpernum 9 .

C. foliis integerrimis ovatis, caule decumbente, cymis dichotomis aphyllis axillaribus. Sp. pl. 321. (Ger. Em. 325.f. 3. Moris. bift. S. 5. t. 30. f. 6. ordine inferiore.)

Oval-leav'd Blite or Allfeed. Anglis.

This plant often grows erect, as well as reclinining: the leaves have frequently a reddin caft. It is faid that fin are fond of it.

maritimum C. foliis fubulatis femicylindricis, sp.pl. $32 \mathrm{r}$. (Oed. Io.

$$
\text { Don. t. } 48 \text { g: opt. Pet. berb. t. 9.f. I.) }
$$

Sea Blite or White-Glaffwort. Anglis.

I found it on the fea coaft in many places, as on the thore near M'Kennon's caftle, in the inle of Skie, and at Glen-beg, on the continent oppofite, and at Loch-Broom, in Ross-fBire, \&c. $\odot$. VIII.

\section{BETA, Gen. Pl, 310,}

Cal. 5-phyllus. Cor. o. Sem. reniforme, intra fubftantiam bafeos calycis.

maritina I. BETA caulibus decumbentibus, floribus geminis. Sp. pl. 322. ES Sy/t. Nat. 195. (Figuram non invenio, fed. f. 2. Ger. Em. 318 . Jimilis eft.) Sea Peet. Anglis. In the Bafle inland. Dr. Parfons. $\odot$. VIII. The young leaves boil'd are wholefome and good greens; 
greens; thofe on the ftalk grow oblique or vertical: the foliola of the calyx are without dent, whereas in the B. vulgaris there is one at the bafe of the carina.

\section{SAI.SOLA. Gen. Pl. $31 \mathrm{I}$.}

Cal. pentaphyllus. Cor. o. Caps. I-fperma. Sem. cochleatum.

kali 1. SALSOLA herbacea decumbens, foliis fubulatis fpinofis fcabris, calycibus marginatis axillaribus. pittillo trifido. Sp. pl. 322 . (Pet. berb. t. g. f. 2. Moris. bijt. $\int \cdot 5 \cdot f \cdot 33 \cdot f .11$. melior.)

Prickly Glaffwort. Anglis.

Upon the fea coaft in fandy places frequent, as on Leitb fands, \&xc. ๑. VII.

The afhes of this plant abound with alkaline falts. One fpecies of the genus (the S. Joda) is much ufed, upon the coafts of the Mediterranean in masing pot-afh, foap and glafs. The term alkali originially took its rife from the falts extracted from the afhes of this laft-mentioned herb, which was called by the Arabic chymilts and phyficians, KALI.

\section{ULMUS. Gen. Pl. 316 .}

Cal. 5-fidus. Cor. nulla. Bacra exfucca, compreffomembranacea.

campeftris I ULMUS foliis duplicato-ferratis, bafi inæqualibus. sp.pl. 327. (Ger. Em. 1478.f. s.)

The Common or Englin EIm. Anglis.

An-leamhan. Goulis. 
In hedges and plantations about Edinburgh, \&c. but in all probability not indigenous.

The variety with a fmooth bark and leaf, com. monly called the $W y c b-E l m$, (Ger. Em. I $48 \mathrm{r}$. $f$. 4.) is much more common in Scotland. I obferv'd it growing wild in the woods as far North as Rofs-jbire and Sutberland. h. IV.

\section{GENTIANA. Gen. Pl. 322.}

Cor. monopetala. Caps. bivalvis, I-locularis. Receptacu, is 2, longitudinalibus.

* Corollis quinquefidis infundibuliformibus.

centaurium GENTIANA corollis quinquefidis infundibulifor1 . mibus, caule dichotomo, piftillo fimplici. Syft. Nat. 200. sp. pl. 332. (Ger. Em. 547.f. r.) Leffer Centory. Anglis. In dry paftures not unfrequent, efpecially near the fea. $\odot$, VII.

amarella 2. GENTIANA corollis quinquefidis hypocrateriformibus fauce barbatis. Sp. pl. 334. (Oed. Dan. 328. opt.)

Autumnal Gentian or Fellwort. Anglis.

In dry mountainous paftures, but not common. $\odot$. VIII.

\section{* Corollisquadrifidis.}

compeftris $3 \mathrm{G}$. corollis quadrifidis fauce barbatis. Sp. $p l .334$. (Oed. Dan. t. 367 . opt. Moris. bift. S. 12. t. 5. f. 9. Barrel. Icon. 97.f. 2.)

Quadrifted Bearded Gentian. Angiis. 


\section{Lus-a'-chrübain. Goulis.}

In dry upind paftures, efpecially in the highlands frequent. $\odot$. VIII. IX.

It varies with purple and with white fowers.

All thefe three gentians are efteem'd to be good ftomachic bitters, and are recommended in the ague, and to ftrengthen the ftomach.

Limnaus informs us that the poor people in Sweden ufe this laft fpecies inftead of hops to brew their ale with.

\section{* U M BEL L A T CE. \\ ERYNGIUM. Gen. Pl. 324. Flores capitati. Receptaculo paleaceo.}

waritimum ERYNGIUM foliis radicalibus fubrotundis plicatis I. fpinofis, capitulis pedunculatis, paleis tricufpidatis. Sp.pl. 337. Syft. Nat. 202. (Ger. Em. 1152. f. I. Moris. bift. . . 7. t. 36.f.6.)

Sea Holly or Eryngo. Anglis.

On the fea coaft in fandy places frequent, as on the finore near Muffelburgh, at Dunbar, at Largo on the coaft of Fife, at Macbrianijb-Bay in Cantire abundantly, and in the illand of Fona, \&r. The young tender hoots, when blanched, may be eaten like arparagus. Lin. Fl. Suec.

HYDROCOTYLE. Gin. Pl. 325.

Umbella fimplex; Involucro 4-phyllo. Petala integra. Sem. femiorbiculato-compreffa.

vulgaris 1. HYDROCOTYLE foliis peltatis, umbellis quinquefloris. 
quefloris. Sp. pl. 338. (Oed. Dan. go. opt. Ger. Em. 529.f. 5. Pet. berb. t. 6.f. 12.)

Marfh Pennywort or White.rot. Anglis.

In bogs, and on the banks of lakes frequent. 2f, VII.

\section{SANICULA. Ger. Pl. 326.}

Umbelle confertæ, fubcapitatæ. Fru\&tus fcaber. Flores difci abortientes.

eurcpara 1. SANICULA foliis radicalibus fimplicibus, flofculis omnibus fefrilibus. Sp.pl. 339. (Oed. Dan.t. 283. opt. Ger. Ent. 948. Moris. bift. S. 5. t. 34. f. 1. ad finifiram in ordine inferiore.)

Sanicle. Anglis.

In woods frequent, as in Coryton woods, \&c. $\boldsymbol{\psi}$. V. VI.

It has long been efteem'd as an aftringent and vulnerary, both in external and internal applications.

\section{TORDYLIUM. Gen. Pl. 330.}

Cor. radiate, omnes hermaphroditæ. Fruitus fuborbiculatus, margine crenatus. Inrolitcra longa, indivifa.

nodofun I. TORDYLIUM umbellis fimplicibus feffilibus, feminibus exterioribus hifpidis. sp. pl. 346. (Ger: Em. 1022.f. 6. Moris. bift.f. 9. t. 14. f. 10. Pet. herb.t. 27.f. II.)

Knotted Parney. Anglis.

On the borders of corn fields, and in dry ftoney places. 


\section{PENTANDRIA DIGYNIA.}

places. Sibbald. Under the Eaft wall in the King's park. Dr. Parjons. ๑. VI.

\section{CAUCALIS. Gen. Pl. 231.}

Cor radiatæ: difci mafculæ. Petala infexo-marginata. Fruetus fetis hifpidas. Involucra integra.

anthrifcus I CAUCALIS umbellis confertis, foliolis ovato lanceolatis pinnatifidis. TORDYLIUM sntbrifats Sp. pl. 346. (Ger. En. 1022.f.5. Moris. bift. S. 9. t. 1 4. f. 8. Pet. berb. t. 27.f. 9.)

Hedgè-Parlley. Anglis.

In hedges and wante places. Sibbald. $\hat{\sigma}$. VIII.

As the flowers in the difk of the umbels are male,

I thought with Mr. Hudfon and Haller it would be more methodical to place this plant under the genus of CAUCALIS than that of TORDYLIUM, in which laft all the flowers are hermaphrodite.

arvenfis 2. C. umbella conferta, involucro univerfali monophyllo, feminibus oblongis, foliolis ovato-lanceolatis pinnatifidis. Hudf. Fl. Ang. 98. (Rivin. $t$. 32. Eै 33. Pet. berb. t. 27.f. 10.)

Small Corn Parney. Anglis.

In corn fields. I obferv'd it in the inland of Lifmore, near Upper-Lorn, \&c. $\odot$. VIII.

Linnaus comprehends this under the preceding fpecies, but its diffure and conftantly dwarfifh growth feem to entitle it to the name of a diftinct fpecies. The flowers of this are always white, in the preceding they are generally reddifh. 


\section{DAUCUS. Gen. Pl. 333 .}

Corolle fubradiatæ, omnes hermaphroditæ. Fructus pilis hifpidus.

casoto 1. DAUCUS feminibus hifpidis, petiolis fubtus nervofis. Sp. pl. 348. (Ger. Em. 1028. Moris. bift. f. 9. t. 13. f. 2. melior. E Moris. Unbelitf. t. 2. p. 31. opt. tamen fine foliis.)

Wild Carrot or Bird's-Neft. Anglis.

In paftures and borders of fields common. $z$. VII. The feeds are a powerful diuretic : an infufion of them in ale or in water as a tea have been found to give relief in the gravel. The garden carrot differs from this only by culture.

\section{BUNIUM. Gen. $P l 335$.}

Corolla uniformis. Umbella conferta. Fructus ovati. bullocafa- BUNIUM. Sp. pl. 349 (Oed. Dan. t. 220. opt. mum 1. Ger. Em. 1064. f. 1 E 2. Moris. bift. f. 9. t. 2. $f$. I. in medio ordinis Secundi.)

Earth-Nut or Pig-Nut. Anglis. Braonan-backuill. Gautis.

In woods and paitures frequent. 24. V. VI. The roots are bulbous, and tafte like a chefnut, whence the trivial name of Bulbocaftanum. Many perfons are fond of them, and in fome parts of Eng! and they boil them in broth, and ferve them up to table.

\section{CONIUM. Gen. Pl. 336.}

Involucella dimidiata, fubtriphylla. Fructus fubglobofus, 5-ftriatus, utrinque crenatus. 
maculatum CONIUM feminibus ftriatis. Sp. pl. 349. (Ger.

Em. 1061. Moris. bift. S. g. t. 6. f. I. ordine inferiore.)

Hemlock. Anglis.

In wafte places frequent. $\odot$. VI. VII.

This plant has certainly narcotic and poifonous qualities, but notwithftanding this it has lately been introduced into the Materia Medica as an excellent medicine to remove almoft every complaint arifing from obftuctions in the glands. The celebrated STORK firt brought it into it's prefent reputation : that gentleman, by many repeated experiments, found, that an extract, prepared from the frefh roots in the Spring, was a very powerful and efficacious remedy in almoft all kinds of ulcerous, fcrophulous, and even cancerous diforders.

\section{ATHAMANTA. Gen. Pl. 338.}

Fructus ovato-oblongus, ftriatus. Petala inflexa emarginata.

eum r. ATHAMANTA foliolis capillaribus, feminibus glabris Atriatis. Sp. pl. 353. (Ger. Em. 1052.f. I. Moris. bift. S. 9. t. 2. fig. media ordinis fuperioris.)

Common Spignel, Meu, or Bawd-Money. Anglis. Muilcionn. Gaulis.

In mountainous paftures in many places, as about Crasuford Fobn Caftle, in Lanerkßire; in the mountains above Dunkeld, and in the paftures about Locb-Rannoch, in Pertbßire, \&c. and Sib- 
bald fays it grows upon the banks of Breick. Water, in Weft-Lotbian. 4. V.

The root has a warm fpicy tafte, and is fometimes ufed in medicine as a carminative and diuretic.

\section{CRITHMUM. Gen. Pl. 340.}

Fructus ovalis, compreffus. Flofculi aquales.

maritimum CRITHMUM foliolis lanceolatis carnofis. sp. pl. 1. 354. (Ger. Em. 533. f. 1. Moris. bift. S. 19. t. 7 . f. 1. ordinis Juperioris.)

Sampire. Anglis.

Upon the rocks by the fea-fide in Galloway. Sibbald. 24. VIII.

The common involucrum confitts of five leaves, the partial ones each of feven.

The leaves of this plant are ufed in England as a well-known pickle, of a warm aromatic flavor.

\section{HERACLEUM. Gen. Pl. 345 .}

Fructus ellipticus, emarginatus, compreffus, ftria. tus, marginatus. Cor. difformis, inflexo-emarginata. Involucr. caducum.

fpbondylium HERAGLEUM foliolis pinnatifidis lævibus, flori 1. bus radiatis. Syft. Nat. 210. Sp. pl. 358. (Ger Em. 1009. Moris. hift. J. 9. t. 16. fig. media or dinis Juperioris. Pet. berb. t. 24. f. 1.)

Cow Parfnep. Anglis.

In meadows and borders of fields frequent. $\hat{\sigma}$ Gmelin, in his Flor. Sibirica, p. 214 , tells us, tha the inhabitants of Comt fchatca, about the be ginning of fuly, collect the footftalks of the ra dica. 
dical leaves of this plant, and after peeling off the rind, dry them feparately in the Sun, and then tying them in bundles they lay them up carefully in the fhade: in a fhort time afterwards thefe dry'd ftalks are cover'd over with a yellow faccharine efflorefcence, tafting like liquorice, and in this ftate they are eaten as a great delicacy.

The Ruffans, not content with eating the ftalks thus prepar'd, contrive to get a very intoxicating fpirit from them, by firft fermenting them in water with the greater Billberries, (Vaccinium uliginofum) and then diftilling the liquor to what degree of ftrength they pleafe, which Gmelin fays is more agreeable to the tafte than fpirits made from corn. This may therefore prove a good fuccedaneum for Whifky, and prevent the confumption of much barley, which ought to be apply'd to better purpoles. Swine and rabbits are very fond of this plant. In the county of Norfolk it is called Hog-weed.

\section{LIGUSTICUM. Gen. $P l .346$.}

Fructus oblongus 5 -fulcatus utrinque. Corolle æquales. Petalis involutis, integris.

foticum I. LIGUSTICUM foliis biternatis, fubtùs lucidis. Lin. Mantiss. 354. Sp. pl. 359. (Oed. Dan. t. 207.opt. Herm. par. t. 227. Pluk. Alm. t. 96. f. 2.) Tour in Scotl. I772, qto. ed. P. 2 h. 205. tab.24. Scotch Parney or Lovage. Anglis. Siunas or Shunis. Gaulis In Jula Skie. 
On the rocks by the fea-fide in many places, as on the coart of Fife, between North and South Weems, and below Kingborne, and frequent in the Weftern illands of Fura, IJla, Fona and Skie, in which laft it is call'd by the name of Sbunis, and is fometimes eaten raw as a fallad, or boil'd as greens. The root is reckoned a good carminative. An infufion of the leaves in whey they give their calves to purge them. 4. VII.

\section{ANGELICA. Gen. Pl. 347.}

Fructus fubrotundus, angulatus, folıdus, ftylis reflexis. Corolle equales; petalis incurvis.

Jylveftris I. ANGEL.ICA foliis rqualibus ovato-lanceolatis ferratis. Sp.pl. 361. (Ger. Em. 999.f. 2. Moris. bift. $\int \cdot 9 \cdot t .3 \cdot f \cdot 2$. orainis Jecundi.) Wild Angelica. Anglis.

In moift woods and marhy places frequent. 4 . VII. It renders hay ungrateful to cattle.

\section{S I U M. Gen. Pl. 348.}

Frufus fubovatus, ftriatus. Involucrum polyphyllum. Petala cordata.

anguftifoli- SIUM foliis pinnatis, umbellis axillaribus pedunum I. culatis, involucro univerfali pinnatifido. Syft. Nat. 21. (Ger. En. 256.f. 2. Moris. bift. f. 9 . t. 5. f. 2. ordinis Secundi. Pet. berb. t. 26. f. 2.) Narrow-leav'd Water Parfnep. Anglis. In ditches and rivulets, but not common. Dr. Parfons. 24. VII.

The fecond pair of pinnæe on the leaves are to diftan: 
diftant from the firft that there feems to be pair wanting: the pinna are deeply ferrated.

rodifioruin $S$. foliis pinnatis; umbellis axillaribus fefilibus. $S p$.

2. pl. 36 . . Moris. bift. . . 9. t: 5.f. 3. benè. Pet. berb. t. 26.j. 3. Oed. Dan. t. 247.)

Reclining Water Parfnep. Anglis.

By the fides of rivulets. 26. VII.

\section{SISON. Gen. Pl. 349:}

Fructis ovatus, ftriatus. Involucre fubtetraphylla. inuidatum SISON repens, umbellis bifidis. $S p \cdot p l .363$. (Oed.

Dan.t. 89. opt. Moris. bif.. S. 9.t. 9. f. 5. Pluk. pbyt. t. 61.f.3. Pet. berb. t. 26. f. 4.)

The left Water Parfnep. Anglis.

In lakes and ponds that are dry'd up in the Summer not uncommon. $\odot$. VII.

It is one of the fmallett plants of all the umbelliferous tribe:

\section{OENANTHE. Gen: Pl. 352.}

Flofculi difformes; in difco felliles fteriles. Fruztus calyce coronatus.

fifuloge I. OENANTHE ftolonifera, foliis caulinis pinnatis filiformibus fiftulofis. Sp. pl: $36_{5}$. (Ger. Em. 1060. f. 5. Moris. bift. S. 9. t. 7.f. 8. Pet. bert. t 25. f. 5 E 6.)

Water Dropwort. Anglis.

In ditches and rivulets, as between Inverkeisbing and the Nortb-Ferry, \&c. 24. VIII. 
The umbels have no univerfal involucrum; whers A partialonesripe the $\boldsymbol{\gamma}_{1}$ refemble fmail prickly fpheres.

crocata 2. OE. foliis omnibus multifidis obtufis fuboqualibis. Sp. pl. 365. (Ger. Em. 1059. f. 4. Moris. bift. S.g.t. $7 \cdot \dot{f} .2$. ordinis Secundi. Pet. berb. $t .25$. f. ..)

Hemlock Dropwort. Anżis.

Upon the banks of ditches, rivers and lakes frequently: 4. VII.

The rays of the univerfal umbel are longitudinally furrow'd, and has no univerfal involucrum: the leaves are fingiy and doubly pinnated : each foliolum is wedge-fhap'd, fmooth, ftreak'd with lines, and notch'd on the edges.

The roots and leaves of this plant are a terrible poifon; feveral perfons have perifhed by eating it thro' miftake, either for water-parfneps or for celeri, which laft it refembles pretty much in its leaves. So extremely deleterious is its nature, that I remenber to have heard the late $\mathrm{Mr}$. Clriftopber D. Elsret, that celebrated botanic painter, fay, that while he was drawing this plant, the fimell or effuvia only rendered hirn fo giddy that he was feveral times oblig'd to quit the room, and walk out in the frefr air to recover himfelf; but recollecting at laf what might probably be the caufe of his repeated illnefs, he opened the door and windows of the room, and the free ail then enabled him to fingif 
his work without any more returns of his giddinefs.

I have feen a large fpoonful of the juice of this plant given to a $\log$, which made him very fick and ftupid, but in about an hour he recover'd : and I have feen a goat eat it with impunity.

To thofe of the human kind, who have been fo unfortunate as to eat any part of this plant, a vomit is the molt approved remedy.

\section{PHELLANDRIUM. Gen. Pl. 353.}

Flofculi difci mincres. Fructus ovatus, lævis, coronatus perianthio \& piftillo.

squaticum PHELLANDRIUM foliorum ramificationibus I. divaricatis. Sp. pl. 366. (Ger. En. 1053. f. 2. Moris. bift. f. 9.t. $7 \cdot f \cdot 7 \cdot$ ordinis Jupcrioris. Pet. berb.t.28.f. 4.)

Water Hemlock. Anglis.

In ditches and ponds, but not common. $\hat{\sigma}$. VIII. The italk is remarkably thick and dichotomous, and grows in the water: the leaves are triply pinnated, the pinnula fefile and ferrated.

Linnous informs us that the horfes in Sweden, by eating of this plant are feiz'd with a kind of palfey, which he fuppofes is brought upon them not to much by any noxious qualities in the plant itfelt, as by a certain infect which breeds in the ftalks, call'd by him, for that reafon; Curculio paraplcaicus. ‘ $y / f$. Not. 610 . 1 he irvedes give fwine's dung for the cure. 


\section{CICUTA. Gen. Pl. 354.}

I'ructus fubovatus, fulcatus.

CICUTA umbellis oppofitifoliis, petiolis marginatis obtufis. p. pl. $3^{66 . ~(O e d . ~ D o n . ~ t . ~ 208 . ~ G e r . ~}$ Ein. 256.f. 4. Moris. bift. S. 9. t. 5 f. 4. Pet. berb. t. $28 . f$. 1. Moris. Umbel. t. 5. Folium egregium Webfer in libello de Cicuta aquatica. $t$. I. p. 4.)

Long-leav'd Water IIemlock. Anglis.

it grows by the fides of lakes, but happily for us very rare. Dr. Parfons difcovered it on the fide of Locb-End. 24. VIl.

The roots are large and hollow, divided into cells by tranfverfe diaphragms: the ftalk round and fitular: the leaves pinnated with fingle, double and triple foliola, each foliolum fpear-fhap'd, and finely ferrated; the ferratures white at the tips: the umbel grows open, and is red at the bafe : the partial inyolucra confift each of many fhort fetaceous leaves: the flowers are white, all hermaphrodite, and uniform: the petals heartfhap'd and inflex'd : the feeds oval, and furrow'd with three prominent meridians.

Of the few vegetable poilons in Great-Britcin this is one of the principal. It is clettruetive not only to man, but, according to moft writers on the fuiject, to almoft every beaft, except perhaps the goat, which is faid to devour it as a grateful food.

...- videre licet pinguefere frepe cicuta-

Barbigeras 


\section{PENTANDRIA DIGYNIA.}

Parbigeras pecudes, homini-que eft acre renenum.

Lucret.

Linneus afiures us that he has known cattle to die by eating the roots; and $V$ Veufer informs us, that one ounce of it threw a dog into convulfions, and two ounces lill'd it: he mentions alio its direful effects upon feveral other animals. And Schwenke, a German writer, gives an account of four boys, who had the misfortune to eat of it; three of whom died in convulfions. Strong emetics, adminifter'd as foon as pofible, are the moft approv'd antidote

\section{FTHUSA. Gen. Pl. 355.}

Involucella dimidiata, triphylla, pendula. Fruetus ftriatus.

cyrapium I. FETHUSA. Sp. pl. 367. (Ger. Em. 1063. f. 1. Moris. bift. f. 9.t. $7 \cdot f \cdot 2$. ordinis Juperioris ad finiftram.)

Leffer Hemlock, or Fool's Parlley. Anglis. It is a common weed in gardens. ๑. VIII. The ftalk is channel'd : the leaves doubly and triply pinnated: the lacinie acute, and deeply ferrated: of a hining dark-green color.

The plant, when brufec, has a ftrong virulent fmell, fomething like garlick. It's qualities correfpond to the fmell, for it is of a poifonous nature, producing ftupors, vomitings and convulfions. Cooks therefore cannot be too careful that they miftake it not for parney, which it a good deal refembles. 


\section{SCANDIX. Gen. Pl. 357 .}

Cor. raciata. Fruczus fubulatus. Petela emarginata. Flofculi difci fæpe mafculi. odorata I. * SCANDIX feminibus fulcatis angulatis. Sp.pl. .368 . (Ger Em. 1039, f. 3. Moris. bijt. J. 9.t. 10.f. 1.) Great Sweet Chervil, or Myrrhe. Anglis.

It is frequent in the low-lands, in orchards, and wafte places, but always near houfes, fo that it is probably not indigenous, but naturalized. 4. V.

The leaves are hairy, triply pinnated, and of a fiweet agreeable fcent: the ftalks channel'd and fiftular: the flowers white.

pecten vene- SCANDIX feminibus lxvibus roftro longifimo. ris. 2 .

Sp. pl. 368. (Ger. Em. 1040.f. 1. Moris. bift. S. 9.t. I1.f. 1. ordinis Secundi.) Shepheri's-Needle, or Venus comb. Anglis. In cum ficlels. Dr. Parfons. O. VI.

antbrifous 3 S. feminibus ovatis hifitis, corollis uniformibus, caule lavi. Sp.pl: 368. (Moris. Jifi. S. 9. t. 10. f. 2. ordinis uperioris. Pet. herb. t. 27. f. 12. Columa.ecpb. 1.p. I10. t.112.)

Small Ifemlock Chervii, with rough feeds. Anglis. In wafte places, and on dry banks near towns and villages. $\odot$ VI.

\section{CHAIROPHYLLUM. Geita $p ? \cdot 358$} Innolucrum relexum, concavum. Petala infexo; corkata. FruEzus oblongus, lævis. 
fyluftre 1. CHEROPHYLLUM caule lovi Atriato, geniculis tumidiufculis. Syft. Nat. 2is. Sp. pl. 369 . (Moris. bift. S. 9. t. In.f. 5. Pet. leerb. t. 25. f. 2.)

Wild Cicely or Cow-weed. Anglis. Under hedges frequent $4 . \mathrm{V}$.

The ftalk is thick, channelled and fiftular, not a!ways tmooth, but frequently hairy : the leaves are triply pinnated : the pinnulae fharply ferrated, generally fmooth, except the nerres, which are always hairy: the petals are unequal, the external ones of the umbel being the largeft. The feeds, when ripe, are blackifh, fmooth, and Thining.

The cows are very fond of this plant in the Spring. The leaves will dye wool of a green and yellow color.

te:mulun 2. CHRROPIYLLUM caule feabro, geniculis tumidis. Sp. pl 370. (Ger. Em. 1038. f. 2. Pet. berb t. 25. f. 3. Moriff. bift. S. 9.t. 10.f. 7.) Wild Chervil. Anglis.

In hedges. 1). Parfons. of. VIII.

The ftalk is hairy, tumid under the joints, and mark'd with red fpots: the leaves are hairy, doubly pinnated : the pinnule cbtufe and nightly ferrated: the young umbels hang down their heads : the petals are unequal, the exterior ones being largeft: the central flowers are abortive: the feeds incoth and furrow'd. 


\section{IMPERATORIA. Gen. Pl. 359.}

Fruktus fubrotundus, compreffus, medio gibbus, margine cinçus. Petala inflexo-marginata.

cffrutbium 1.

IMPERATCRIA. Sp.pl. 37I. (Ger. Em. ICOI. f. I. Moris. bift. $\int .9 . t_{0} 4 f$. I.)

Mafterwort. Anglis.

I obferv'd it upon the banks of the Clyde in feveral places, particularly about Ardencople, and in the ille of Bute, near Mountftervart; but whether indigenous or not is uncertain. 4 . VI.

The leaves are pinnated with about five pinnæ, the extreme one always divided into three lobes, and all tharply ferrated.

The root is warm and aromatic, and is efteem'd a good fudorific. There are recorded inftances of it's curing the ague, when the bark has fail'd. It fhould be dug up in the Winter, and a frong infufion macie in wine.

\section{SMYRNIUM. Geir. Pl. 363 .}

FruEtus oblongus, ftriatus. Petala acuminata carinata.

olufatrum I SMYRNIUM foliis caulinis ternatis petiolatis ferratis. Sì).pl. 376. (Ger. En. 1019. Moris. bift. f. 9. t. 4 . f. I. ordinis Secundi. Pet. berb. t. 24.f. I2) Alexanders. Anglis.

Upon the fea coaft at Dunglass, on the edge of: Ber roickbire. Dr. Parjons. o. VI. 


\section{CARUM. Gen. pl. 365 .}

Fructus ovato oblongus, ftriatus. Involucim nionophyllum. Petala carinata, infexo-emarginata. carui I. ". CARUM. sp. pl. 378, (Ger. En. 1034. Pet. berb. t. $26 . f$ 10.)

Caraways. Angiis.

Under the rocks of Edinburgh cafte, towards the Weft. Dr, Parfons. I obferv'd it alfo growing in the inland of Oransa, but moft probabiy from feeds accidentally icattered. $\delta$. VI.

The feeds are a well-known carminative. The young leaves are good in foups, and the roots are by fome efteem'd a delicate food.

\section{PIMPINELLA. Gen. $p l .366$.}

Frutius ovato-oblongus. Petala inflexa. Sitgmo fubglobofa.

axifraga I. PIMPINELLA foliis pinnatis, foliolis radicalibus fubrotundis; fummis linearibus. $s p . p l .37 s$. (Ger. En. 1044. f. 2. Moris. bift. . . 9. t. . . f. 6. ordinis Juperioris.)

Small Burnet Saxifrage. Anglis.

In dry mountainous paftures frequent. 4. VIII.

There is a variety of it with the radical leaves laciniated. $\gamma$. Pet. berb. t. $26 . f .8$.

\section{APIUMf. Gen. p?. $3^{67}$.}

Fructus ovatus, friatus. Invo'ucr. monophyllum. Petala æqualia.

raveoleas APIUM folis caulinis cuneiformibus, umbellis fefrilibus. 
fefiilibus. Sp. pl. 379. (Ger. Em. 1014. Moris. bift. . 9. t. 9.f. 8. Pet. berb. t. 26.f. 12.)

Smallage or Celeri. Anglis.

in marhy places by the fea fide: in the ditches behind Muffelburgh. Dr. Parfons. o. VIII.

\section{FGOPODIUM. Gen. pl. 368.}

FruEZus ovato-oblongus, ftriatus.

podagraria EGOPODIUM foliis caulinis fumm.s ternatis. I: Sp. p!. 379. (Ger. Em. 1011.f. 2. Moris. bift. S. 9. t. 4.f. 11. Pet. berb.t. 25.f. 10.)

Gout-Weed, Afh-Weed, or Herb-Gerard. Anglis. Under hedges and in gardens. 4. VI.

The young leaves in the Spring are eaten in Sweden and Switzerland as greens.

\section{T R I G Y I A.}

VIBURNUM. Gen. pl. 370.

Cal. 5-partitus, fuperus. Cor. 5-fida. Bacca monofperma.

Gantana I. VIBURNUM foliis cordatis ferratis venofis, fubtus tomentofis. Sp. pl. 384. (Ger. Em. I49o.) The VVay-faring-Tree. Anglis.

At Sir Fobn Hall's, in Dunglafs-Glen. Dr. Parfons. 々. VI.

opulus 2. V. foliis lobatis, petiolis glandulofis. Sp. pl. 384 (Ger. Em. 1424.f. I.)

Water Elder. Ang/is.

In moift woods and hedges, but not common. Dr Parjons. h. VI. 


\section{SAMBUCUS. Gen. pl. $3 ; 2$.}

Cal. 5-partitus. Cor. 5 fida. Bacca 3-fperma.

elulus I. SAMBUCUS cymis tripartitis, ftipulis foliaceis, caule herbaceo. Sp. pl. 385. Syjt Nat. 219. (Miller. icon. 226. opt. Ger. Em. 1426.)

Dwarf-Elder or Dane-wort. Anglis.

By way fides, but not common. I obferv'd it near Dumfries, in thie road from thence towards Caerlavrock caftle, and at Duplin, the feat of Lord Kinnoul, near Perth, \&c. 24. VII.

The leaves have three or four pair of pinnæ, much longer than thofe of the common elder: the tips of the petals are red and inflex'd.

The roots are a powerful diuretic: a decotion of them has been found ferviceable in the droply.

jigra 2.

SAMBUCUS cymis quinquepartieis, caule arboreo Sp.pl. $3^{8} 5$. (Ger. Em. 1422.f. 1.)

Common Elder. Anglis. An druman. Gaulis. In woods and hedges frequent. $\zeta$. VI.

An infuifon of the inner green bark of this fhrub in white wine, or it's exprefs'd juice to the quantity of half an ounce, or an ounce, is faid to prove a moderate cathartic, and in fmall dofes to be an efficacious deobftruent. The bruifed leaves in a cataplafm are fometimes applied outwardly in eryfipelas and pleurifies, and are reckoned to be very relaxing. The dryed flowers are a fudorific, and the juice of the berries, infpiffated to the confiftence of a rob, proves a fafe and 
and ufeful aperient medicine, good in obftruccions of the vifcera, and to promote the natural evacuations. The berries are alfo ufed to make a wine, which has fomething of the flavor of frontiniac; and in fome countries they dye cloth of a brown color with them. 'The young umbels before the flowers expand are by fome efteen'd for pickling.

\section{AISINE. Gen. Pl. 380.}

Cal. pentaphyllus. Petala 5, æqualia. Capfula unilocularis, trivalvis.

media 1. ALSINE petalis bipartitis, foliis ovato-cordatis.

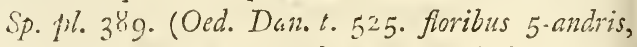
E t. 43 S. foribus 10-andris. Moris. bift. S. 5.t. 23.f. 4. Gor. En. 611.f.2.)

Common Chickweed, Anglis.

In hady places and in gardens frequent. $\odot . V$-IX. It varies in is number of flamina from three to ten. Chickens and many kinds of imall birds are very fond of this plant.

\section{T E T R A G Y N I A.}

PAKNASSIA. Gen. pl. 834 .

Cal. 5-partitus. Petala 5. Nectaria 5, cordata, ciliata apicibus globofis. Capjula quadrivalvis.

gangtris I. PARNASSIA. sp. pl. 39I. (Moris. bift. S. I2. $t$. 10.f. 3. Ger. Emac. 840.f. 1.)

Grafs of Parnaffus. Anglis. In bogs and wet paftures frequent. 24. VIII. 


\section{PENTANDRIA PENTAGYNIA.}

The ftalk is about a foot high, angular, and often a little twifted, bearing a fingle white flower at top: the leaves are heart-hap'd, thofe on the ftalk feflile: the flower is white, with five ftriated petals : the nectaria are of a yellowin green color, heart-Phap'd and ciliated: the cilia terminated each with little yellow pellucid fpheres;

a very diftinguifhing character of this plant.

\section{PEN T A G Y N I A.}

STATICE. Gen.pl. 388 .

Cal. I-phyllus, integer, plicatus, fcariofus. Petale 5. Sem. 1, fuperum.

armerio I. STATICE fcapo fimplici capitato, foliis linearibus. sp.pl. 394. (Moris. bif. S. I5. t. I. f. 29. Ger. En. 602.f. I. Pet. bert. t. 72.f. 8.)

Thrift or Sea Gilly-flower. Anglis. Bìr-dearg. Gaulis.

The moft humble and mont lofty of plants. It grows frequently upon the fea-Phores, and upon the fummits of the highert mountains. 24. VII.

LINUM. Gen. pl. 389 .

Cal. 5-phyllus. Petala 5. Capfula 5-valvis, 10-locularis. Sem. folitaria.

* Foliis alternis.

"Iftatiff- LINUM calycibus capfulifq; mucronatis, petalis mum2 $\mathrm{t}$ crenatis, foliis lanceolatis alternis, caule fubfolitario. Sp. pl. 397. (Ger. En. 556. Moris. bift. f. 5. t. $26 . f . t$. ad dexiran ordinis fecundi.) 
Flax. Anglis. Liòn. Gaulis.

In corn fields. $\odot$. VI.

Not to mention the great oconomical ufe of this plant in making of linen, the feeds are efteem'd an excellent emollient and anodyne : they are ufed externally in cataplafins, to affuage the pain of inflam'd tumors : internally, a night infulion of linfeed, by way of tea, is recommended in coughs as an excellent pectoral, and of great fervice in pleurifies, nephritic complaints, and fuppreffions of urine.

\section{* Foliis oppofitis.}

catbarticum L. foliis oppofitis ovato-lanceolatis, caule dichoto: 2. mo, corollis acutis. Sp. pl. 40 r. (Ger. Em. 560. f. 5. Pet. berb. t. 55. f. 12.)

Purging Flax. Anglis. An caol-miòfachan. Gaulis. In dry paftures common. $\odot$. VI.

A drachm of the dry'd plant pulveriz'd, or an infufion of a handful of it in whey or water, is a fafe purge.

radiola 3. L. foliis oppofitis, caule dichotomo, floribus te. trandris tetragynis. Sp.pl. 402. (Oed. Dan. 178. opt. Raj. Syir.p. 348.t. I 5.f. 3. V cil.paris. t. 4. f. 6. Ger Em. 569:f. 2. pet. berb. t. 59.f. 12.) The leit Rupture-wort, or All-feed. Anglis. In moift gravelly foils, and where water has ftooc in the Winter ; obferv'd at $Y$-coimmb-kiil ty $\mathrm{Fol}$ Banks, Efquire. $\odot$. VIII. 


\section{DROSERA. Gen. pl. $39 \mathrm{r}$.}

Cal. 5-fidus. Petala 5. Caps. I-locularis, apice 5valvis. Sem. plurima.

rotundifolia DROSERA fcapis radicatis, foliis orbiculatis. $S p$. 1.

$$
\begin{aligned}
& \text { pl. } 402 \text {. (Ger. Em. 1556.f, 1. Pet. berb. t. } 63 . f \text { : } \\
& \text { 10.). }
\end{aligned}
$$

Round-leav'd Sundew, Anglis. Lus-na-fearnaich. Gaulis.

On bogs and heathy grou:dds frequent. 24. VII.

longifolia 2. D. fcapis radicatis, foliis oblongis. Sp. pl. 403. (Ger. Em. 1556.f. 2. Moris. hijt. S. 15.t. 4. f. 2. Ev var. fig. altera ad dextram ordinis Juperioris. Pet. berb. t. 63.f. II E I 2.)

Long-leav'd Sundew. Anglis.

In the fame places as the preceding, and equally common. 4. VII,

Thefe plants are readily diftinguifhed by their leaves, which are cover'd on the upper fide with purple tubular hairs, tipp'd with drops of a vifcid liquor: the ftalk is deftitute of leaves, and bears a sp:ke of white flowers, all for the mort part on the fame fide of the ftali.

\section{SiPBALDIA. Gen. pl. 393.}

Cal. 10.fidus. Petala 5, calyci inferta. Styli e latere germinis. Sem. 5 .

procumbens SIBBALDIA foliolis tridentatis. Sp. pl. 406: (Oed. 1.

Dan.t. 32. Pluk. Alm.t. 312.f. 3.) Reclining Sicbaldia. Anglis. 
Upon many of the highland mountains, as on BenLomond in Dumbarton/hire, Ben-mor in Breadalbane, \&c. It begins to grow about a mile from the tops, and continues to be found quite to the fummits. It has never been difcover'd in any other part of Great-Britain, except Scotland.

\section{P O L Y G Y N I A.}

MYOSURUS. Gen. Pl. 394.

Cal. 5-phyllus, bafi adnatus. Nectaria 5, fubulata, petaliformia. Sem. numerofa.

minimus 1. MYOSURUS. Sp. pl. 407. (Oed. Dan. t. 406. Ger. Em. 426.f. 4. Pet. berb. : 39. f. 7.) Moufetail. Anglis.

In corn-fields of a gravelly foil. Sibbald. $\odot . V$. 


\section{H E X A N D R I A.}

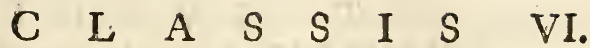

H E X A N D R I A

\section{O NOG Y N I A.}

* Flores calyculati callyce corollaque inftructi.

BERBERIS. Cor. 6-petala. Cal. 6-phyllus; inferis. Bacca 2-fperma:

* Flores spatbacei, seu glumacei.

ALLIUM. Cor. infera, 6-petala. Pet. ovata, feffilia.

$$
\text { * Flores nuidi. }
$$

CONVALLARIA. Cor. infera, 6-fida. Bacca 3 fperma.

HYACINTHUS. Cor. infera, 6-fida. Germinis ad apicem pori 3 melliferi.

ANTHERICUM. Cor. infera, 6.petala, plana. ORNITHOGALUM. Cor. infera, 6-petala. Filam. alternis bafi dilatatis.

SCILLA. Cor. infera, 6-petala, decidua. Filam. filiformia.

$$
\text { * Flores iricompleti. }
$$

JUNCUS. Cal. 6-phyllus. Caps. I-locularis. PEPLiS. Cal. 12-fidus. Caps. 2-locularis. DIGYNIA. Polygona varia. 


\section{$\begin{array}{lllllllll}T & R & I & G & Y & N & I & A\end{array}$}

COLCHICUM. Cal. fpatha. Cor. 6-petaloidea. TRIGLOCHIN. Cal. 3-phyllus. Cor. 3-petala. Caps. bafi dehifcens.

RUMEX. Cal. 3.phyllus. Cor. 3.petala. Sem. 1, triquetrum.

Anthericun calyculatum.

\section{P O L Y G Y N I A.}

ALSIMA, Cal. 3-phyllus. Cor. 3-petala. Pericarp. plura.

\section{$M O N O G Y N I A$.}

BERBERIS. Gen. Pl. 442 .

Cal. 6-phyllus. Petala 6, ad ungues glandulis 2 . Stylus o. Bacca 2-fperma.

valgaris I. BERBERIS pedunculis racemofis Lin. Sp. 47I. (Miller. icon. t. 63. Ger. Em. 1325.)

The Barberry-bufh. Anglis.

In the hedges about Hamilton. Dr. Parfons. 万. VI. The fruit is cooling, and good to quench thirft in fevers, for which purpofe it is generally made. into a conferve.

The inner bark, fteep'd in white wine, is purgative, and has been found often to be very ferviceable in the jaundice.

\section{ALLIUM. Gen. Pl. 409.}

Cor. 6-partita, patens. Spatbo multifora. Umbella congefta. Caps. fupera. 


\section{HEXANDRIA MONOGYNIA:}

- Foliis caulinis planis; umbella bulbifera.

arcmarium I ALLIUM caule planifolio bulbifero, vaginis teretibus, fpatha mutica, ftaminibus tricufpidatis. Sp.pl. 426. (Haller. opufcul. de Allio. t. 2. f. 2: Moris. bift. f. 4. t. 14. f. 5: Oed. Dan. t. 290. Secundum Hallcrum.)

Broad-leav'd Mountain Garlick. Anglis.

At the foot of mountains in fandy foils; but not common. 4. VII.

The flowers and bulbs or the umbel are of a pur. plifh color.

* Foliis caulinis teretibus.

vineale 2. AI.LIUM caule teretifolio bulbifero, ftaminibus tricufpidatis. Sp. pl: 428. (Ger. Em. I79. f. I. Pet. berï. t. 66. f. 1:)

Crow-Garlick. Anglis.

In dry paftures, but not very common: Under $S_{6}$. lifuury-Craigs, \&c. 4. VI.

*** Foliis radicalibus, fcapo nudo.

urfinum 3. A. fcapo nudo triquetro, foliis lanceolatis petiolatis; umbella faftigiata: $s p . p l$. 431. (Ger. Em. 179. f. 2. Moris. bift. f. 4. t. 15. f. 15: Pet. berb: $t$. 66. f. 8.)

Ramfons. Anglis:

In moift woods, and on the fides of rivulets not unfrequent, as at Drumlanrig in Nithfdale, in the woods by Roflin-Caftle, at Locb-Ronfa in the ine of Arran, \&c. 24. VI.

If cows happen to feed upon it the garlick odor 
will be communicated to the milk, butter and cheefe.

The inhabitants of Arran take an infufion of the leaves for the grayel with good fuccefs.

frboenopra- A. fcapo nudo adæquante folia teretia fubulato fum 4. -filiformia. Syft. Nat. 240. Sp. pl. 432. (Moris. bift. S. 4. t. 14.f. 4. ordinis Juperioris. Ger. Em. s $76 . f$. 1.)

Cives or Chives. Anglis.

By Faft-Cafte, on the borders of Berwick/bire. Dr. Parfons. I was inform'd that it had been found alfo in Netber-Lorn, in Argyleßire.. 44. VII.

\section{ORNITHOGALUM. Gcn. Pl. 418.}

Cor. 6-petala, ereeta, perfiftens, fupra medium pa= tens. Filamenta alterna bafi dilatata.

luteum r.

ORNITHOGALUM fcapo angulofo diphyllo, pedunculis umbellatis fimplicibus. $S p$. pl. 439. (Oed. Dan. t. 378. opt. Ger. Em.165.f. 2. Moris. hijt. . 13. t. 4.f. 12. Pet. berb. t. 66.f. 12.)

Yellow Star of Bethlehem. Anglis.

In woods. It flowers at the fame time with the ranunculus Ficnria. 24. III \& IV.

I have inferted this as a native of Srotland, on the authority of Sibbald, and the certainty of it's growing in Nortbumberland.

The petals are green on the outfide, and yellow within.

SCILLA. Gen. Pl. 419.

Cor. 6-petala, patens, decidua. Filamenta filiformia. bifolia 



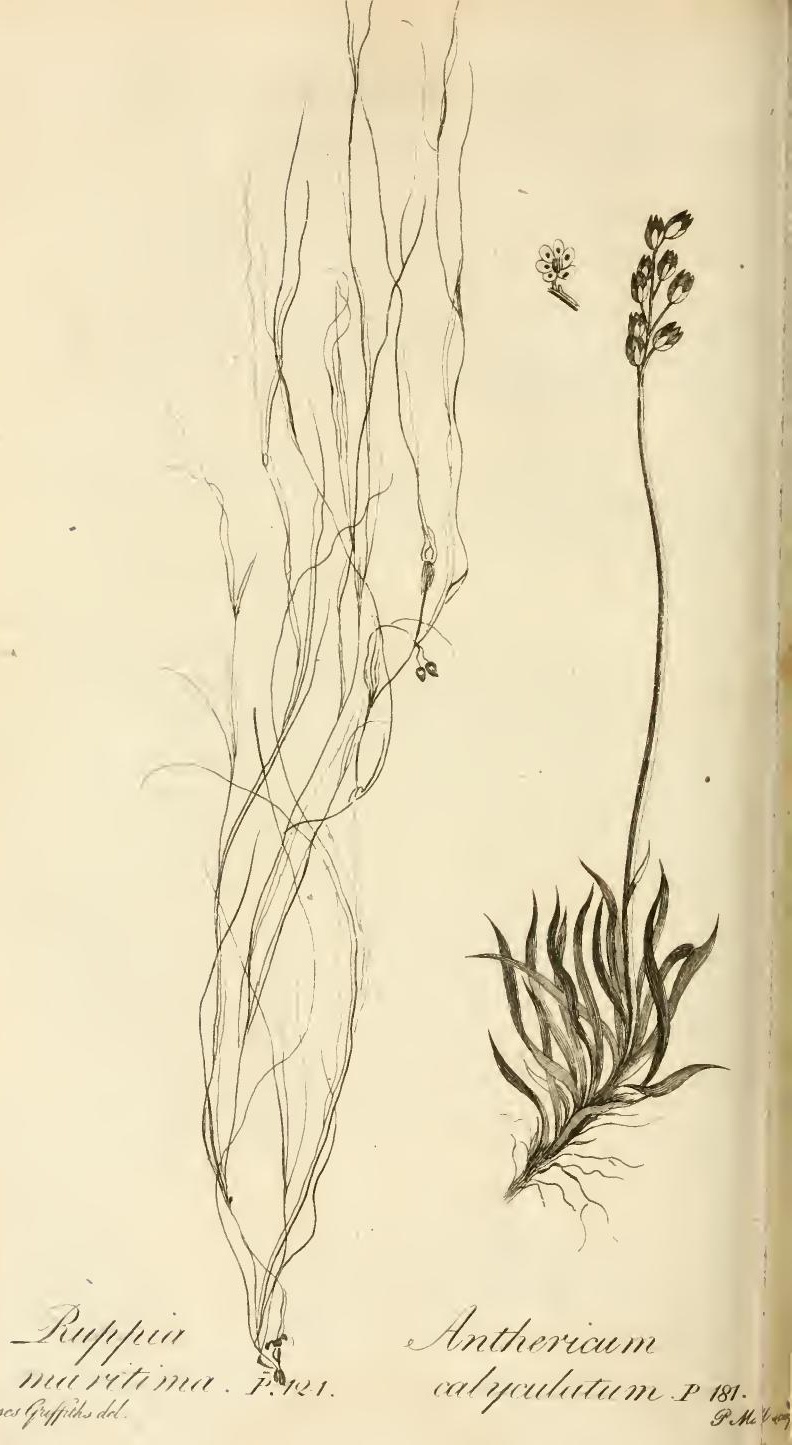




\section{IIEXANDRIA MONOGYNIA.}

bifolic 1. SCILLA floribus erectiufculis paucioribus. $S p . p l$.

- 443. (Ger. Em. 106. f. 1. Moris. bift. S. 4. t. 12. f. 1 5. Pet. berb. t. 67.f. 5.)

Vernal Star Hyacinth. Anglis.

Upon rocks cover'd with a Thallow foil, in the inands of Fona and Staffa abundantly, \&r. 24. V. The root is bulbous, confifting of feveral coats like an onion: the radical leaves are two or three : the ftalk naked, about four inches high : the flowers erect, blue, in number from two to ten.

\section{ANTHERICUM. Gen. Pl. 422.}

Cor. 6-petala, patens. Caps. ovata.

offregum I ANTHERICUM foliis enfiformibus, filamentis lanatis. Sp. pl. 446. (Oed. Dan. t. 42. opt. Ger. Em. 95.f. 2, Moris. bift. S. 4. t. 1. f. 7. Pet. berb, t. 66. f. 9.)

Lancafhire-Afphodel, or Yellow Marfh Anthericum. Anglis. Am bliocan. Gaulis.

Very common in moorith grounds all over Scotland, and the Weftern ines. 24, VII. VIII.

calyculatuy: A. foliis enfiformibus, perianthiis trilobis, filamen2. tis glabris, floribus trigynis. Syft. Nat. 244. Sp. pl. 44.7. (Oed. Dan. t. 36. opt. Flor. Lapp. t. 10. f. 3. E fig. no/t.)

Scotch Afphodel, or White Mountain Anthericum. Anglis.

Upon feveral of the highland mountains, as about Loch Rannoch, in Perthpire, \&c. I obferv'd it 
alfo in the inland of Rum, upon a mountain call'd Baikevall.

The flowers grow in a clafe fpike: the peduncles fingle, with a fmall trifid kind of bractea at their bafe, refembling a calyx; whence the trivial name of calyculatum.

\section{CONVALLARIA. Gen. Pl. 425.}

Cor: 6-fida. Bacca maculofa, 3-locularis.

$$
\text { * Corotlis campanulatis. }
$$

iszajalis I. CONVALLARIA fcapo nudo. $s p \cdot p l: 451$. (Ger. Em. 410.f. I. Moris bift. f. I 3.t., 4. f. 1. Pet. berb.t. $46 . f .7$. )

Lilly of the Valley, or May-Lilly. Anglis.

At Scotland-Wald, and at Metbren.Wood. Sibbald. 4. V.

\section{*: Corollis infundibuliformibus.}

malizflora 2 CONVALLARIA folis alternis amplexicaulibus, caule tereti, pedunculis axillaribus multilloris, Sp. pl. 452. (Miller. icon. 101. f. г. Oṣd. Dan, t. 152. Ger. Em. 903. f. I. Pei. bert. t. 44. f. 5.) Solomon's Seal. Anglis.

In woods but not common. I obferv'd it in the woods about Tibber-Caftle, near Drumlanrig, in Ni.bjale. 2i. V. VI.

\section{HYACINTHUS. Gen. pl. 427.}

Cor. campanulata; pori tres melliferi germinis.

gon fcriptus HYACINTHUS corollis campanulatis fexpartitis 

apice revolutis. $S p$. pl. 453. (Ger. Em. III. f. I. Pet. berb. t. 67. f. 4 .)

Englifh Hyacinth, or Harebells. Anglis. Am fuath-muc. Gaulis.

In woods not unfrequent, as in Coryton woods, and on the South fide of the river oppofite Logton wood, by Dalkeith, \&c. 24. V.

\section{JUNCUS. Gєn. $\not l .437$.}

Cal. 6-phyllus. Cor. o. Caps. I-locularis.

* Culmis nudis.

conglomera- JUNCUS culmo nudo ftricto, capitulo laterali.

tus 1 .

ip.pl. 464. (Moris. bitt. S. 8. t. so. f. 7.)

Clufter-flower'd Rufh. Anglis.

In wet and marfhy grounds. 4 . VII.

This rufh is ufed to make wicks for candles, and the pith of it to make toy-bankets.

effusus 2. JUNCUS culmo nudo ftricto, panicula laterali. sp.pl. 464 . (Moris. bift. S. 8.t.10.f. 4.)

Common Soft-Rurh. Anglis.

In marhy grounds. 24. VII.

This is likewife ufed for making candle-wicks, and in fome places for ropes and baikets.

infexus 3. J. culmo nudo, apice membranaceo incurvo, panicula laterali. i $p . p l .464$. (Moris bift. S. 8. t. 10. f. 25. E ejus var. $\gamma$ ? S. 8.t. 10.f. I3.)

Hard-KuIh. Anglis.

Upon the thores on the coalt of Fife. Dr. Parfons. 4. VII.

trifidus 4. J. culmo nudo, foliis floribufq; tribus terminalibus. Sp. 


\section{HEXANDRIA MONOGYNIA.}

Sp. pi. 465 . (Oed. Dan. t. 107. Baub. Prod. p. 22. t. 22. fig. ad dextram. Exempla nottra monantha funt. vid. fig.)

Trifid Rum. Anglis.

I found it upon the fummits of the highland mountains to the South of Little-Loch-Broom, in Ro/sfire, and on Ben-nu-fcree, above Arnefdale, on the fide of Locb-Urn, in Inverne/sfoire, \&c. 4. VII.

It varies with one, two and three axillary, and almoft fefilie flowers. The fpecimens I found had all fingle flowers.

fquarrofus J. culmo nudo, foliis fetaceis, capitulis glomeratis 5. aphyllis. Sp. pl. 465. (Oed. Dan. t. 430. Loes. Priff.p. I15. t. 29. Moris. bift. S. 8. t. g. f. 1 3 : benè.)

Moís Ruh. Anglis.

In moorih heathy ground common. 4. VII.

The leaves are rigid, and spread open from one another: the ftalk is erect and ftiff: the glumes at the bafe of the calyx, and the edges of the leaves of it white: the capfule of a dark red $_{2}$ and thining.

\section{** Cuminis foliojis.}

ariculatus JUNCUS foliis nodofo-articulatis, petalis obtufis. 6. Sp. pl. 465. (Moris. bift. f. 8. t. 9.f. r. ad dex-

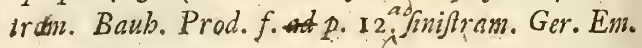
p. 22.f. 9.)

Jointed-leav'd Ruh. Anglis. 
In woods and moift meadows frequent. 4 . VIII.

A yariety of this, froducing bunches af reddin leaves, inftead of umbels of flowers, is frequent in bogs and ditches in the Autumn. ( ( ee fig. Baub. Prod.p. I 2. ad dextram. EO Moris. bift. fo 8.t.g.f. 2.) Thefe leaves feem to put on this appearance from fome obitruction in the growth of the plant, occafion'd by an infect of the Coccus tribe.

The flowers alfo in the Autumn are frequently viviparous, the germina thooting young leaves before the feeds are ripe, as in the following:

sulbofys \%. J. foliis linearibus canaliculatis, capfulis obtufis. Sp. pl. 4.66. (Oed. Dan. t. 431. Moris. bift. S. S. t. $9 . f$. I 1.)

Bulbous Rụ̂h. Anglis.

Frequently upon the fea-coaft, and in moift meadows. 24. VIII.

The capfules are obture, and of a dark-brown fhining color; fometimes viviparous. See Pluk. t. 32. f. 3. E'. Echeuch. Agroft. p. 330. t. 7.f. 10. Moris. bift. . 8. t. 9, f. 4. ordinis Secundi.

bufonius 8. J. culmo dichotomo, foliis angulatis, foribus folitariis fefilibus. $S p . p l .466$. (Moris. bift. $.8 . t$. 9. f. 14. Barrel. icon. $26_{3} \mathrm{E}_{2} 26_{4}$. Ger. Em. p. 4 . f. 4.)

Toad-Ruh. Anglis.

In places that have been overflow'd in the Winter. ๑. VIIT.

This 
This is likewife found fometimes viviparous.

sriglumis 9. JUNCUS foliis planis, gluma triflora terminali, sp. pl. (Oed. Dan. t. 132. Flor. Lap. t. 10.f. 5. E' fig noft.)

'Three-Howerr'd Ruf̣h. Anglis.

Upon the highland mountains, but not common; on the Eaft fide of Craig-Chealleach, above Finlarig, in Breadalbane, \&c. Mr. Stuart.

The glume and capfules are chocolate-color'd.

pilofits io. J. foliis planis pilofis, corymbo ramofo. $s p \cdot p l .468$ :

(Oed. Dan. t. 441. Moris. bift. S. 8.t. 9. f. x. ordinis Juperioris ad finiftram.)

Hairy Wood Rufh. Anglis.

In wocds frequent. $24 \mathrm{~V}$.

fylraticusy J. Soliis planis pilofis, umbella fupradecompofita floribus fubfeffilibus. Hudf. Flor. Angl. 132. J. pilofus var. j. Lin. ip. pl. 468. (Moris. bift. S. 8. t. $9 \cdot f \cdot 2$ ordinis futerioris ad finiftram.)

Great hairy Wood-Kuth. Anglis.

In vooc's and fhady places; on the banks of the river at Rofin, near Edinburgh. Dr. Parfons. भ. Y.

campeftris J. foliis planis pilofis, fpicis feffilibus pedunculatif12. que. Sp. pl. 468. (Moris. bift. S. 8. t. g. f. 4. ordinis fupericr:s. Ger. Em. p. 17.f. 2.)

Hairy Pafture-Rufh. Anglis.

Frequent in dry paftures. 24. IV.

A variety of this, with an erect ftaik, and compact globular 
globular heads of flowers, often occurs in moorith grounds, flow'ring a month later. (Moris. bifl.f. S.t. g.f. prima ordinis fuperioris.)

Spicatus 13. J. foliis planis, fpica racemofa nutante. $S p \cdot p l \cdot{ }_{4} 6 g$. (Oed. Dan. t. 270. Fl. Lapp. t. 10. f. 4.) Alpine Nodding.Rufh." Anglis.

Upon the fides of the highland mourtzins, near their fummits : upon Ben-na-fcree, on the North fide of Locb-Urn, on the Weftern coaft of Invernessfire, \&c. 4. VII.

The ftalk bends in an arc towards the top, bearing at the extremity a clofe oblong fpike of flowers: the leaves are fometimes a little hairy at the bafe. It is very nearly related to the preceding fpecies.

\section{PEPLIS. Gen. pl. 446 .}

Pericinth. campanulatum, ore i 2 -fido. Petala 6, calyci inferta. Caps. 2-locularis.

portula 1. PEPLIS foribus apetalis. $S p \cdot p l$. 474. (Oed. Dan. t. 64. opt. Loefel. Pruff. t. 20. Michel. gen. t. 18. fig. Juperior, Vail. Paris, t. 15.f. 5: Ger. Em. 61 4. f. 11.)

Water Purnane. Anglis.

in places that have been overfow'd in the Winter not uncommon. ๑. VIII.

The ftalks are angular, and creep upon the ground: the leaves grow in pairs, fmooth, with long footItalks, but rounded at the extremity: the flowers are feffile in the alre of the leaves, and frequently without any petals. 


\section{T $R I G Y N I A$.}

RUMEX. Ger. pl. $45 \mathrm{r}$.

Cal. 3-phyllus. Petala tria, conniventia. Serr. unicum triquetrum.

* IIermapbroditi. valvulis granulo notatis.

riffus I. RUMEX floribus hermaphroditis, valvulis integris graniferis, foliis lanceolatis undulatis acutis. $S_{p}$. pl. 47 5. (Pet. ber3. t. 2.j. 2.)

Curled Dock. Anglis.

BV way-fides and near houfes frequent. 24. VI. VII. The lower leaves are oval and obtufe, the upper ones lanceolate, all of them curl'd, or wav'd on the edges: from the ala of the leaves, and at the top of the plant, grow loofe fpikes, the younger ones thick, and not intermix'd with leaves : the valves of the feeds are entire on the edges, very large ${ }_{2}$ and mark'd on their fides with glands or yellow warts.

maritisus RUMEX foribus hermaphroditis, valvulis denta2. tis grapireris, foliis linearibus. $S p \cdot p l .478$. (Pet. berb. t. 2.f. 8. Bocc. mws. 2. p. 142.t. 104.) Golden Dock. Anglis.

On the fea-coaft in low wet places, but not common. 24. VIII.

- catus 3. R. floribus hermaphroditis, valvulis dentatis graniferis, foliis cordato-oblongis acuminatis. $S p$. pl. 47 8. (Ger. Em. 388.f. I.)

Sharp-pointed Dock. Anglis. Copagach. Gaulis. 
In moilt deep foils under hedges and in paltures frequent. 21. VII.

The root is woody, thick; of a dark-brown color without, and yellow within: the ftalk four or five feet high: the leaves lanceolate, and indented on the edges: the flowers grow in loofe, naked fpikes, hermaphrodite and female often intermix'd.

A decotion of the root, taken internally, is recommended againft the fcurvy, and other cutaneous diforders.

-btriffolius R. floribus hermaphroditis, valvulis dentatis grani4. feris, foliis cordato-oblongis obtufufculis crenulatis. Sp. pl. 478. (Ger. Em. 388.f: 3. Pet. berb. t. 2.f. g.)

Broad-leav'd Dock, Anglis.

By way-fides and wafte places frequent. 24. VII. Dr. Parfons.

The leaves are of an oblong, oval figure, a little crifp'd on the edges, and emarginated about the footftalks : the flowers grow in thick fpikes, uninterrupted with leaves: the cients on the edges of the valves are numerous, and nearly as long as the diameter of the valves.

oulcber 5. RUMEX floribus hermaphrodicis, valvulis dentatis, fubunica granifera, foliis radicalibus pandu. riformibus. Sp. pl. 477. (Pet. lacrb. t. 2. f. 10. Moris bift. . 5.t.27.f. I3.)

Fiddle-Dock. Anglis.

By way-fides in dry places. Sibkaid. 2. Y1. 
The radical leaves have a deep finus in their edges on each fide, and are befides a little crifp'd : the ftalk ones are lanceolate: the branches are angular and divaricated: the flowers grow in diftant feffile whirls: the valves are dentated, with an obtufe apex; the exterior one has a large wart or grain, the other fearcely any.

** Hermapbroditi, valvulis granulo deftitutis, $\int$. nudis. aguaticus $6 \mathrm{R}$. floribus hermaphroditis, valvulis integerrimis nudis, foliis cordatis glabris acutis. Syft. Nat. 255. Sp. pl. 479. (Pet. berb. t. 2.f. I. Ger. Em. $389 \cdot f$. I.)

Great Water Dock. Anglis.

In ditches and by river-fides. Sibbald. 24: VII.

This may be readily known from the other fpecies

by the fize of the leaves, which are a foot and a half long, or more, of a lanceolate elliptic form, cordated at the bafe;

The root in decoction or effence is efteem'd an ex. cellent antifcorbutic, and pulveriz'd is reckon'd a good dentifrise:

digynus 7. RUMEX floribus hermaphroditis đigynis. $s p . p l$. pl. 480 . (Oed. Dan. t. 14. opt. Moris. hilt. f. 5. t. 36. f. penultim. Pluk.t. 252. f. 2. Pet. berb. t. 3 . $f .4$.)

Round-leav'd Mountain Sorrel. Anglis.

Sealbhag-nam-fiadh. Gaulis.

Upon rocks by the fides of rivulets, which rur down from the highland mountains, very frequent: I obferv'd it likewife in the inands of Rum and skye in the fame kind of places. 
The leaves are kidney-fhap'd: the calyx has only two leaves: the flower two petals, with fix ftamina, and two ftyles : the germen comprefs ${ }^{\prime} d$.

\section{* Floribus declinis.}

acetofa 8. R. floribus dioicis, foliis oblongis fagittatis. Sp. pi. 481. (Ger. Em. 396.f. I. Moris. bift. S. 5.t 28. f. I. ordinis fuperioris.)

Common Sorrel. Anglis. Sealbhag. Gaulis. In meadows and paftures. 24. VI.

The leaves of the calyx in the male flowers are obture ; in the female acuminated and reflex'd, and wav'd on the margins.

The Laplanders boil a large quantity of the leaves in water, and mix the juice, when cold, in the milk of their rein-deers, which they efteem an agreeable and wholefome food, and which will keep in a cool place for a long while.

The leaves are an agreeable acid, and are reckon'd a good antifcorbutic.

acetofella g. R. floribus dioicis, foliis lanceolato-haftatis. $S p . p$ l. 48 1. (Ger. Em. 397. f. 3. Moris. bift. f. 5. t. 28. f. I 1 Eे 1 2. Pet. berb. t. 3.f. 2 है 3.) Sheep's-Sorrel. Anglis. In dry paftures frequent. 24. V-VII.

\section{TRIGLOCHIN. Gen. pl. 453 .}

Cal. 3-phyllus. Petala 3 fcalyciformia. Stylus o. Caps. bafi dehifcens.

paluftre t. TRIGLOCHIN capfulis trilocularibus fublinearibus. 
bus. Sp.pl. 482 . (Oed. Dan. t. 490. opt. Moris. bift. S. 8. t. 2.f. 18.)

Arrow-headed Grafs. Anglis.

In wet meadows and by the fides of ditches. 2 . VIII.

Linnous fays that cattle are very fond of this and the following fpecies.

"Haritimutit

2.

T: capfulis fexlocularibus ơvatis. $s p \cdot p l \cdot 48,3 \cdot(\mathrm{Oed}$ Dan. t. 306. opt:) Sea-fpiked Grafs. Anglis. Upon the fea-coafts frequent. 4 : VII.

\section{COLCHICUM. Gen. pl. 457 .}

spatba. Cor. 6-partita, tubo radicato: Caps. 3łconrexæ, inflatæ.

sutumnale COLCHICUM foliis planis lanceolatis erectis. Sp.

1. pl. 485. (Ger. Em. 157. f. I E 2. Moris. bift. S: 4. t. 3.f. I. Pet. berb.t. 67.f. 2.)

Meadow Saffron. Anglis.

In low meaciows, but not common. I obferv'd it at Alloa, about the feat of Mr. Erfkine. 2. IX.

The naked purple flowers appear in Autumn; the leaves and feed veffels do not fucceed 'till the following Spring.

The root is a folid bulb, cover'd with a yellow fkin on one fide of it is a furrow, from which arifes the tube of the flower.

An oxymel, prepar'd from the roots, gathered in the beginning of the Summer, and adminifter'd in the quantity of fix drachms to a boy, and an 


\section{HEXANDRIA POLYGYNIA.}

ounce and half to a man, by a drachm at a dofe ${ }_{i}$ three or four times a day, has, in feveral ina ftances, been found to cure the dropfy, but in more has fail'd.

\section{P O L Y G Y N I A. \\ ALISMA. Gen. Pl. 460.}

Cal. 3-phyllus. Petala 2. Sem. plura. plintago a- ALISMA foliis ovatis acutis, fructibus obtufe triquatica I. gonis. Sp. pl. 486. (Ger. Enz. 41\%,f: 1.)

Great Water Plantain. Anglis.

On the banks of lakes frequent, as at DudiftonLoch, \&c. 24. VII. Dr. Parjo s.

The leaves are large, fmooth, oval and pointed : the ftalk erect and naked: the flowers white, and fmall in proportion to the plant, growing in a large open panicle: the branches verticillate.

ranunculoi- A. foliis lineari-lanceolatis, fructibus globofo-fquardes 2. rofis. Sp. pl. 48\%. (Ocd. Dan. it. 122, opt Ger. Em. $417 . f$ 3. Pet. berl. t. 43.f. 8.)

Leffer Water Plantain.

In ditches and bogs, but not common. I obferv'd it in ditches and by the fides of lochs in the iland of Ifl. 24. VII. 


\section{L A S S I S VII. \\ H E P T A N D R I A \\ $M O N O G Y N I A$.}

TRIENTALIS. Cal. 7-phyllus. Cor. 7-partita, plana. Bacca 1-locularis, ficca.

\section{$M O N O G Y N I A$.}

TRIENTALIS. Gen. pl. $46 \mathrm{r}$.

Col. $\%$-phyllus. Cor. 7-partita, xqualis, plana. Bacca exfucca.

europar 1. TRIENTALIS foliis lanceolatis integerrimis. $s p$. pl. 488. (Oed. Dan. t. 84. opt. Bauh. Prod. 99. Moris. bift. S. 12. t. Io. f. 6. ordinis inferioris. Pet. berb. t. 62.f. 3.)

Chickweed Winter-Green. Anglis.

On the fides of the highland mountains in moorih ground, as on Ben-Lonnond, about a mile of the way up, \&c. and in the Duke of Atbol's woods at Blair abundantly, \&rc. 4. VI.

The ftalk is fingle, and about five inches high, terminated with five, fix or feven oval pointed leaves, from the centre of which arife on long footitalks commonly two white ftomy flowers, each confifing generally of feven oval and equal petals, 

petals, fucceeded by a globular dry berry, cover'd with a thin white rind, having one cell, containing feveral angular feeds. 
G $\quad \mathrm{L} \quad A \quad S \quad S \quad I \quad S \quad$ VIII.

$\begin{array}{lllllllll}O & C & T & A & N & D & R & \text { I A }\end{array}$

\section{$\mathrm{M} O \mathrm{NO}$ G Y N I A.}

* Flores completi.

EPILOBIUM. Cor. 4-petala. Cal. 4-phyllus, fuperus. Caps. 4-locularis. Sem. pappofa!

CHLOKA. Cor. 8-fida. Cal. 8-phyllus, inferus. Caps. I-locularis, 2-valvis, polyfperma.

VACCINIUM. Cor. 1-petala. Cal. 4 dentatus, fuperus. Filament. receptaculi. Bacca.

ERICA. Cor. I-petala. Cal. 4-phyllus, inferus. Fillam. receptaculi. Capfula.

Monotropa Hypopitbys.

* Flores incompleti.

DAPHNE. Cal. 4-fidus, corollinus, æqualis. Stam. inclufa. Bacca pulpofa.

$$
\text { D I G Y N I A. }
$$

* Cblora perfoliata. Chryfopplenition.

$$
\text { T R I G Y N I A. }
$$

pOLYGONUM. Cor. o. Cal. 5-partitus. Sem. x. nudum.

$$
\text { T E T R A G Y N I A. }
$$

ADOXA. Cor. 4-s. 5-fida, fupera. Cal. 2-phyllus. Bacra 4-s. 5-fperma. 


\section{OCTANDRIA MONOGYNIA.}

PARIS. Cor. 4-petala, fubulata. Cal. 4-phyllus.

Baeca4-locularis.

\section{$M O N O G Y N I A$. \\ EPILOBIUM. Gen. pl. 47 I.}

Cal. 4-fidus. Petala 4. Caps. oblonga, infera. Sem. pappofa.

** Staminibus declinatis.

anguftifoli- EPILOBIUM foliis fparfis lineari-lanceolatis, flouni $\mathrm{I}$.

ribus inæqualibus. Sp. pl. 493. (Oed. Dan. $t$. 280 opt. Moris bift. $\int .3 . t$. II.f. I. ordinis $\int u-$ perioris ad dextram. Ger. Em. 477.f. 7. Pel. berb. t. 52.f. 10.)

Rofebay Willow-herb. Anglis.

In woods and on rocks by the fides of mountains, as in Coryton woods, and among the rocks to the Eaft of the Kirk of Sbots, near Hamilton. Dr. Parfors. And twenty miles Weft of Sierling, near Loch-Lutnaig, by the road from Tiendrum. Mr. Stuart. 2f. VII.

An infufion of the leaves of this plant has an intoxicating quality, as the inhabitants of Camtfcbatfca have learnt, who likewife eat the white young fhoots, which creep under the ground, and brew a fort of ale from the dry'd pith of it. The down of the feeds has lately been manufactured by mixing it with cotton or beavers hair.

* Staminibus ereelis regularibus, petalis bifidis. rutum 2. E. foliis oppofitis lanceolatis ferratis decurrenti-im- 


\section{OCTANDRIA MIONOGYNIA.}

plexicaulibus. Zin. sp pl. 494. Oed. Dan. t. 326. cpt. Noris. bijt. f. 3.t. $11 \mathrm{f} \cdot 3$. Ger. Em. 476.f. 6. Pet.kerb. t. 52.f. 11.)

Great hairy Willow-herb, or Codlings and Cream. Anglis.

On the fides of ditches, rivers and lakes. 24. VII. 3. There is a variety of this, according to Linnaus, much fmaller in all it's parts, with leaves a little undulated on the edges, and the ftalks not much branched, which Hudfon, in his Flor. Angl. confiders as a diftinct fpecies, and perhaps not unjuitly. See Pet. berb. t. 52.f. 12.

Small-flower'd hairy Wiilow-herb. Anglis.

By the fides of lakes, \&xc. 24. VII.

grontanu? 3 EPILOBIUM folis oppofitis ovatis dẹntatis. $S p$. fl. 494. (Ger. En. 478. t. 11. Pet. berb. t. 53 . f. I.)

Smocth-leav'd Willow-herb. Anglis.

By ditch-fides and under hedges in a gravelly foil rlequent. $\hat{o}$. VII.

The leaves are harply ferrated, and generally fmooth. except the nerves on the under fide, which are nightly hairy: the flower is very little bigger than the calyx.

Eeiragonum E. folitis lanceolatis centiculatis; imis oppofitis, 4. caule tetragono. (p. pl. 494. I.jg. nulla credenda) Nia row-leav'd Willow-herb. Anglis.

On the banks of ditches, \&c. 4. VII. The leaves are fmooth and fefrile, nightly indented 


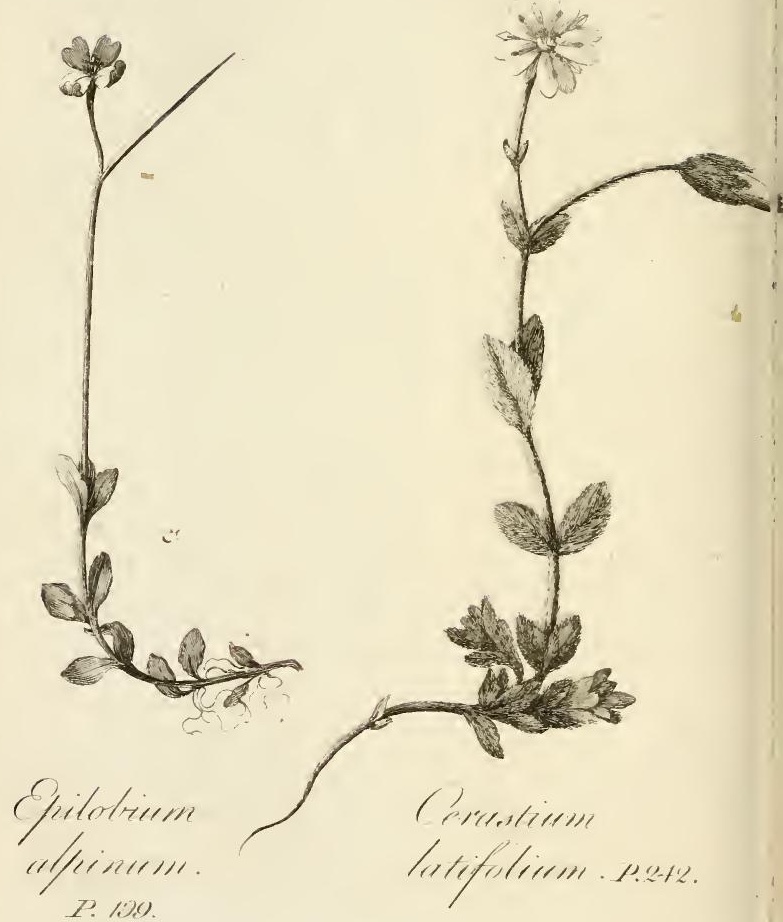
on the edges, and fometimes intire: from their bafe run two prominent lines down the ftalk, fo as to make it appear obtufely tetragonal: the flower is about the fize of the calyx, and the tigma not quadrifid, but intire.

paluftre 5. E. foliis oppofitis lanceolatis integerrimis, petalis emarginatis caule erecto. Sp. pl. 495. (Pet. beró. t. 53.f. 4. E ejus vor. Ger. Em. 477.f. 8 . E? Moris bift. S. 3 t. In.f. 2. orainis Secundi.)

Marn Willow-herb. Anglis.

Upon bogs and on the fides of lakes. 24. VII. The leaves are flightly hairy, and generally intire on the edges, but fometimes have a ferv dents; they commonly grow oppofite at the bafe of the ftalk, but frequently alternate at the top: the ftalk is round, and the petals are but llightly emarginated.

alpinun 6. EPILOBIUM foliis oppofitis ovato-lanceolatis integerrimis, flliquis feffilibus, caule repente. ip. pl. 495. (Oed. Dan.t. 322. E fig. noft.)

Alpine Willow-herb. Anglis.

By the fules of the rivulets which run down the highland mountains in many places, as on Ben. Lomond, about two-thirds of the way up, on the mountains near Little-Loch-Broom, in RossBire, in fandy places, and on feveral others. 4. VI. Vil.

The ftalk is about three or four inches high, reclining at the bafe, and even creeping at firft, bu: 
but afterwards growing erect, and l earing only one or two flowers at the top: the leaves and filiqua are quite fmooth; the latter four or five times longer than the former.

\section{CHLORA. Mientiss. Gen. pl, Lin. 1258.}

Cal. 8-phyllus. Cor. I-petala, z-fida. Caps. I-locularis, 2-valvis, polyiperma.

pirfoliata I CHLORA foliis perfoliatis. Lim. Syft. Nat. 267. Gentiana perfoliata. Sp. pl. 335. Blackftonia Hudf. Fl. Ang. 146. (Ger. Em. 54\%.f. 2. Moris. bift. $\int .5$. t. 26. $f$. I E 2. ordinis fuperioris ad finiftram, fed vitiofè quoniom petal. Segm. 5. tantim. Berrel. icon. 515 E 516 melior. Pet. berb. t. 55.f. 8.)

Yellow perfoliate Centory. Anglis.

In mountainous paftures, but not common. $\odot$. VII.

The leaves of this elegant plant are of a bluein green, or glaucous color, which makes a beautiful contraft with its bright yellow ftarry flowers. It has two ftigmas and no ftyle.

\section{VACCINIUM. Gen. pl. 483 .}

Cal. fuperus. Cor. t-petala. Filamenta receptaculo inferta. Bacca +-locularis polyfperma.

* Foliis amotinis Jeu deciduis.

(a) Ytilitus is VACCINIUM pedunculis unfloris, foliis ferratis ovatis deciduis, caule angulato. Sp.pl.49S. (Ger. (in. $1415 . f .1$. 
Black=Whorts, Whorte-Berries, or Billberries. Anglis.

Ius-nan-dearc. Goulis.

In woods and on heaths abundantly. $\zeta$. V.

The flowers frequently vary with five fegments at the rim, and with ten ftamina.

The berries when ripe are of a blueifh black color, but a fingular variety, with white berries, was difcovered by his Grace the Duke of Atbol, growing in the woods about the mid-way between his two feats of Dunkeld and Blair.

The berries have an aftringenc quality. In Arran and the Weftern inles they are given in diarrheas and dyfenteries with good effect.

The Higblanders frequently eat them in milk, which is a cooling agreeable food, and fometimes they make them into tarts and jellies, which laft they mix with Whifkey to give it a relifh to ftrangers. They dye a violet color, but it requires to be fix'd with alum. The grous feed upon them in the Autumn.

sligino unn

VACCINIUM pedunculis unifloris, foliis integerrimis ovalibus obtufis lavibus. \&y/t. Nat. $26 \%$. Sp. pl. 499. (Oed. Dan. t. 23r. opt. Ger. Em. I $416 . f .6$.

The great Billberry-Bußh. Anglis.

Dearca roide. Goulis

It is found in low moift grounds, and almoft at the fummits of the highland mountains, as upon Creg.Chailleach in Breadolbane, upon the higher 
higher hills about Locb-Rannoch in Atbol, upon the mountains of Rols-fbire, about Loch-Broom, and Inverne/s-pire about Eocb-Urn, \&c. and in the low boggy grounds of the inland of $M u l l$, and near the Duke of Argyle's, at Inverary, dic. 万. V.

The leaves are full of veins, fmooth and glaucous, efpecially on the under fide: the berries are eatable, but not fo much efteem'd as the preceding, as they are apt, if eaten in any quantity, to give the head-ach.

\section{** Foliis Sempervirentibus.}

vitisidea 3 VACCINIUM racemis teminalibus nutantibus, foliis obovatis revolutis integerrimis fubtus punctatis. sp. pl. 500. (Oed. Dan. t. 40. opt. Ger. Em. $1415 \cdot f \cdot 2$.

Rea Whortle-Berries. Anglis.

Icus-nam-braoileag. Gaulis.

in dry places in heaths, woods, and on mountains, very frequent. $h . V$.

The berries have an acid cooling quality, ufeful to quench the thirft in fevers. The swedes are very fond of them made into the form of a rob or jelly, which they eat with their meat as an agreeable acid, proper to correct the animal alcali.

axycaccos $4 \mathrm{~V}$. follis integerrimis revolutis ovatis, caulibus repentibus filiformibus nudis. $s p . p l .500$. (Oed. Don. t. So.opt. Ger. Em. 419.)

Cran-berries, 
Cran-berries, Mors-berries, or Moor-berries. Anglis. Mùileag. Gaulis.

On peat-bogs in the lowlands frequent, but not fo common in the highlands. h. VI.

The ftalks are long, nender, woody, weak and trailing : the leaves are ftiff, acutely oval, glou. cous underneath, their edges turn'd back, and grow alternate: two or three flowers grow fingly on long red foottalks out of the extremity of the branches : the flowers are red, divided deeply into four acute fegments, which are reflex'd quite backwards: the filaments are downy, the antheræe ferrugineous, and longer than the filaments: the berries red, and about the fize of the hawthor: berries.

At Longtown, on the borders of Cumberland, they are made fo confiderable an article of commerce, that at the feafon when they are ripe, not lefs than 20 or 30 pounds worth are fold by the poor people each market day for five or fix weeks together, which are afterwards difpers'd over different parts of the kingdom, for making the well-known cranberry-tarts.

EKICA. Gen. pl. $4^{8} 4$.

Cal. 4-phyllus. Cor. 4-fida. Filamenta receptaculo inferta. Anthere bifidæ. Caps. 4-locularis.

whis r. ERICA antheris bicornibus inclufis, corollis inæqualibus campanulatis mediocribus, foliis oppofitis fagittatis. Sp.pl. 50 I. (Gir. Em. I 380.f. I.) Common IIeath, or Ling. Anglis. Hather. Scotis. Fraach. 
Fraoch. Gaulis.

In barren uncultivated foils and woods abundantly. 々. VI-Vill.

The leaves are tetragonal, and grow in four imbri cated feries; the uppermoft have angles at the bafe like the barbs of an arrow: the flower: grow in a thick fike on one fide of the ftalk. each fubiended by a fmall bractea: the calyx remains after the flower fades, and clofes over the capfule for its fecurity.

It varies fometimes with hoary leaves.

cincrea 2, E. antheris bicornibus inclufis, corollis ovatis racemofis, foliis ternis glabris linearibus. $S p . p l .50 \mathrm{r}$. (Oed. Dan.t. 38. opt. Ger. Ein. 1382.f. 7.) Fine-leav'd Heath. Anglis. Hather. Scotis. Fraoch. Gaulis.

In uncultivated foils and woods the moft common of al? prants. h. VII-VIII. Heath o: Hather is apply'd to many cconomical purpors anongin the Higblanders : they frequently cover their houfes with it inftead of thatch, or elfe twin it into ropes, and bind down the thatch wir them in a kind of lattice-work: in moft of the Weftern ines they dye their yarn of a yellow color, by boiling it in water with the green tops and flowers of this plant : in Rum, Skye, and the Long-Ifland, they frequently tan their lcather in a ftrong decoction of it: formerly the young tops are fa:d to have been ufed ahone to brew a kind of ale, and even now I was 
inform'd that the inhabitants of Ifla and Fure ftill continue to brew a very potable liquor by mixing two-thirds of the tops of hather to onethird of malt. This is not the only refrenment that hather affords: the hardy Higblanders frequently make their beds with it, laying the roots downwards, and the tops upwards; which, tho" not quite fo foft and luxurious as beds of down, are altogetier as refrefhing to thore who fleep on them, and perhaps much more healthy.

tetralix 3. ERICA antheris bicornibus inclufis, corollis fubglobofis aggregatis folio longioribus, foliis quaternis ciliatis patentibus. Syft. INat. 26g. Sp.pl. 502. (Oed. Dan. t. 8 1. Ger. Em. 1 38 r.f. 4.)

Crofs-leav'd Heath. Anglis.

In moorih grounds very frequent. $々$. VII. VIII.

\section{DAPHNE. Gın. pl. 485 .}

Cal. o, Cor. 4-fida, corollacea, marcefcens, ftamina includens. Bacca I-fperma.

laureola I. DAPHNE racemis axillaribus quinquefloris foliis lanceolatis glabris. Syft. Nat. 272. Sp. pl. 510. (Ger. Em. 1404.)

Spurge Laurel. Anglis.

Upon the banks of the river at Roflin. Dr. Parfons. দ. III. IV,

The whole plant is flexible: the leaves evergreen, and crouded at the fummits of the branches : the Aowers are greenifh: the anthere yellow: the berries biack when ripe. 
It is extremely acrid and cauftic, and therefore rarely ufed in the prefent practice.

\section{T R I G Y N I A.}

\section{POLYGONUM. Gen. pl. 495.}

Cal. o. Cor. 5-partita, calycina. Sem. I, angulatum.

* Biftortæ Spica unica.

biforta 1. POLYGONUM caule fimplicifimo monoitachyo, foliis ovatis in petiolum decurrentibus. $s p . p l$. 516. (Oed. Dan. t. 42 I. Miller. icon. 66. Ger. Em. 399.f. 1.)

The greater Biftort, or Snakeweed. Anglis.

In moift meadows, but not common. I obferv'd it about Invercry. 24. VII.

The root has an acid auftere tafte, and is a powerful aftringent: the leaves are by fome boil'd in the Spring, and eaten as greens.

viviparum POL.YGONUM caule fimplicifimo monoftachyo, 2. foliis lanceolatis. Sp. pl. 5 16. (Oed. Dan. t. I3. opt. Ger. Em. 399.f. 2. Plukenet. t. I5 . f. 2.) Small Biftort, or Snakeweed. Anglis.

In dry ftony paitures by the fides of mountains not unfrequent, as about the pafs of Killicranky, near Blair, on the fides of the mountains about Locb Rannocb in Pertbfisire, Loch-Urn in Inverness-pire, \&rc. and on Ben-buardal, in Stratb, in the inte of Skye. 24. VI.

The lowermoft flowers of the fpike generally put 
on the appearance of little red bulbs, which fometimes germinate upon the ftalk.

The inhabitants of Camtfcbatca, and fometimes the Norwegians, when prefs'd with hunger, feed upon the roots of this plant.

** Perficaria piftillo bifido, aut famina minus 8.

ampbisium 3 .

P. floribus pentandris femidigynis, fpica ovata. Syft. Nat. 275. Sp.pl. 517. (Oed. Dan.t. 282. opt. Moris. bift. S. 5. t. 29.f.2. ordinis Juperioris ad dextram. Pet. berb. t. 3:f. 12.)

Perennial Arfmart. Anglis.

In ponds, lakes, and wet ground. थै. VII.

When it grows in the water the ftamina are fhorter than the flower, when upon land longer than the flower, with two diftinet ftyles.

perficaria 4 P. floribus hexandris, digynis; fpicis ovato oblongis, foliis lanceolatis, ftipulis ciliatis. Sp.pl. 518. (Ger. Em. 445. f. 2. Moris. bift. S. 5. t. 29. f. 2. ordinis secundi. Pet. berb. t. 3.f. 7.J

Dead or Spotted Arfmart. Anglis.

In moift ground and wafte places frequent. $\odot$. VIII.

The nerves of the leaves on the under fide are hairy. A decoction of the plant with alum dyes a yellow color.

bydropiper POLYGONUM floribus hexandris femidigynis, 5. foliis lanceolatis, fipulis fubmuticis. $s p \cdot p l .517$. (Ger. Em. 445. f. 1. Moris. bif.. S. 5. t. t. 29.f. 6. Pet.herb.t.3.f. 5.)

TVater 
Water Pepper or Arfmart. Anglis.

By the fides of ditches and lakes. Dr. Parfons \& Sibbald. $\odot$. VIII.

The leaves are quite fmooth, without fpots, acrid and biting to the tafte: the fpikes flender and nodding: the flowers feffile and thinly fet.

It is a diuretic, but feldom ufed. A decoction of it dyes a yellow color.

*** Polygona foliis indivifis, floribus oizandris.

aviculare 6 P. floribus octandris trigynis axillaribus, foliis lanceolatis, caule procumbente herbaceo. $S p . p l .519$. (Ger. Em. 56r.f. т. Pet.herb. t. 10.f. 1.)

Knot-Grafs. Anglis.

By way-ficies common. ๑. VI. IX.

The fmall birds are extremely fond of the feeds of this plant.

It varies much in the Thape of the leaves, they are generally lanceolate, but frequently oval, and fometimes almort round.

Upon the fandy fhores on the Weftern coatt of Cantire I obferv'd a fingular variety, with very large oval and thick leaves, approaching nearly to the P. maritimum, but was not perennial.

**** HELXINE foliis fubcordatis.

convolsuln s POLYGONUM foliis cordatis, caule volubili anๆ. gulato, floribus obtufatis. Syft. Nat. 276. Sp. pl. 522. (Ger. Em. 863.f. 5. Moris. bift. S. 5.t. 29. f. 2. ordinis fupcrioris ad finiftram. Pet. berb. t. 2. f. i2.) 
Black Bindweed. Anglis.

In corn-fields and near the fea-coafts frequent. $\odot$. VII. VIII.

\section{T E T R A G Y I A. \\ PARIS. Gen. pl. 500 .}

Cal. 4-phyllus. Petala 4, anguftiora, Bacca 4-locularis.

quadrifolia PARIS. sp.pl. 526. (Oed. Dan. t. I 39. opt. Ger. I. Em. 405.f. I. Pet. berb. t. 44.f. 8) Herb Paris, True-love, or One-berry. Anglis. In a wood about a mile to the South of Nerwbottle, near Dalkeith. Dr. Parfons. And in the Den of Betbaick, four miles from Perth. 24.V.

It is readily known by having four oval, feffile leaves, growing verticillate at the top of the ftalk, with a fingle greenifh lower in the centre of them, fucceeded by a black berry.

\section{ADOXA Gen. pl. 50 r.}

Cal. bifidus, inferus. Cor. 4-s. 5-fida, fupera. Bacca 4-s. 5-locularis, calyce coalita.

nofchatelli- ADOXA. Sp.pl.527. (Oed. Dan.t. 94. opt. Moris. na $\mathrm{x}$. bift. S. 4. t. 28.f. I 4. Ger. Em. sog I. f. I0.) Tuberous Mofchatel. Anglis.

In woods and hady places in a loofe foil, but not very common : in the Hermitage. Dr. Parfons. Mr. Stuart found it near the top of Creg-Chaillech, à hill lying between Killin and Glen-Lyon, in Breadalbane. 24. V. 
The root is fiiform and fcaly : the ftalk fingle, angular, and four or five inches high : the radical leaves are about four in number, branched into dowicly ternate divifions : the foliola fmooth and divided generally into three lobes; their footftalks channel'd : two fimply ternate leaves grow oppofite to each other above the middle of the ftalk: the peduncle is quadrangular, naked, and terminates the ftalk, on the fummit of which grows a cubical clufter of five green flowers, with yellow antheræ; the uppermoft of which flowers is quadrifid, the lateral ones quinquefid: the berries are green, the calyx and corolla remaining on them. 


\section{E N N E A N D R I A.}

$\begin{array}{llllllll}C & L & A & S & S & I & S & \text { IX. }\end{array}$

E N N E A N D R I A

$\mathrm{H}$ E X A G Y N I A.

BUTOMUS. Cal. c. Cor. 6-petala. Caps. 6, polyfpermæ.

\section{H E X A G Y N I A.}

BUTOMUS. Gen. Pl. $50 \%$.

Cal. o. Petala 6. Caps. 6, polyfpermæ.

umbellatus I BUTOMUS. sp. pl. 532. (Moris, bift.. . 12. t. 5. f. penult. Ger. Em. 29. f. 2.)

Flowering-Rufh, or Water-Gladiole. Anglis.

In ditches and ponds, but not common. 2 . VII. The leaves are radical, triangular, and fwordfhap'd : the ftalk erect, round, naked, and five feet high, terminated with an umbel of red flowers, each confifting of fix oval petals. 
D E C A N D I A.

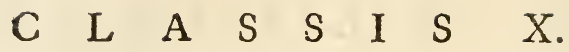

D E $\quad$ C A N

MO N O G Y N I A.

* Flores polypetali equales.

MONOTROPA. Cal. corollinus, bafi gibbus. Caps. 5-locularis, polyfperma.

PYROLA. Antbera. furfum bicornes. Caps. 5-10cularis, polyfperma.

* Gerania.

** Flores monopetali aquales.

ANDROMEDA. Cor. campanulata, rotundata. Caps. 5-locularis.

ARBUTUS. Cor. ovata, bafi diaphana. Bacca 5locularis.

$$
\begin{aligned}
& \text { * Vaccinia nomulla. } \\
& \text { D I G Y N I A. }
\end{aligned}
$$

SCLERANTHUS. Cor. nulla. Cal. 5-fidus, fuperus. Sem. 2.

CHRYSOSPLENIUM. Cor. nulla. Cal. fuperus.

Caps. 2-locularis, 2-roftris.

SAXIFRAGA. Cor. 5-petala. Cal. 5-partitus.

Caps. I-locularis, 2-roitris.

DIANTHUS. Cor. 5-pctala. Cal. tubulofus, bafi.

jquamofus. Caps. 1-locular. oblonga. 


\section{DE C A N D R I A. T R I G Y N I A.}

ARENARIA. Caps. 1-locularis. Petala integra patentia.

STELLARIA. 'Capss. I-locularis. Pet. bipartita, patentia.

CUCUbalus. Caps. 3-locularis. Pet. bifida, fauce nuda.

SILENE. Caps. 3-locularis, Pet. bifida fauce coronata.

CHERLERIA. Caps. 3-locularis. Nestar. petaloidea calyce minora.

\section{P E N T A G Y N I A.}

COTYLEDON. Caps. 5 ad nectaria. Cor. 1-petala.

SEDUM. Caps. 5 ad nectaria. Cor. 1-petala. S.ERGULA. Caps. I-locularis. Petala integra. Cal. 5-phyllus.

CERASTIUM. Caps. I-locularis. Petala bifida. Cal. 5-phyllus.

AGROSTEMMA. Caps. I-locularis, oblonga. Cal. tubulous, coriaceus.

LYCHNIS. Caps. 3-locularis, oblonga. Cal. tubulofus, membranaceus.

OXALIS. Caps. 5 locularis, angulata. Cor. bafi fubcohœrens.

* Adoxa.

Gerania. 


\section{$\begin{array}{lllllllll}M & O & N & O & G & Y & N & I & A .\end{array}$}

MONOTROPA. Gen. Pl. 536 .

Cal. o. Petala 10, horum 5 exteriora bafi excavatomellifera. Caps. 5-valvis. Quinta pars numeri quibusdam excluditur.

bypopitbys MONOTROPA floribus lateralibus octandris, terI. minali decandro. Sp.pl. 555. (Oed. Dan. t. 232. opt. Moris. bift. S. 12. t. 16.f. 13. ordinis inferioris. Plukenet. t. 209.f. 5.)

Primrofe-fcented Hypopithys. Anglis.

In beach and fir-woods, where the ground is dry, and bare underneath, but not common. 24. VII. The radical fibres adhere to the roots of the trees under which it grows: the ftalk is about five inches high, having no other leaves than oval fcales, and terminated with a nodding fpike of flowers, which in the feeding ftate becomes ereet : the whole plant is of a pale yellow color, fmelling like the primrofe, or like beans in bloffom.

\section{ANDROMEDA. Gen. pl. 549 .}

Cal. 5-partitus. Cor. ovata, ore 5-fido. Ceps. 5-locularis.

tolifolia I. ANDROMEDA pedunculis aggregatis, corollis ovatis, foliis alternis lanceolatis revolutis. $S p$. pl. 564 . (Oed. Dan. t. 54. opt. Flor. Lappon. t. 1. f. 2. Plukenet. t. 175.f. 1.) Marfh Andromeda, or Marfh Rofemary. Anglis. 

In peat-bogs in the Lowionds not unfrequent, and abundantly upon Solway-MoSs, on the borders of the two kingdoms. 5 . V. \& IX.

This elegant little fhrub is about fix or eight inches high, erect and branched: the leaves are fefile, elliptical, rigid, their edges turn'd back, green on the upper fide, giaucous underneath: the peduncles are of a bright red color, and arile from the fummits of the branches, each fupporting one fingle oval flower, of a pink color, with a red calyx.

\section{ARBUTUS. Ger. pi. 552.}

Cal. 5-partitus. Cor. ovata, ore bafi pellucida. Bacca 5-locularis.

aipina I.

ARBUTUS caulibus procumbentibus, foliis rugofis ferratis. Sp.pl. 566. (Oed. Den. t. 73. Ger. Em. 1416.f. 4. Eं fig. noftra.)

Alpine Arbutus. Anglis.

Upon many of the highland mountains in dry barren places, particularly on thofe to the South of Litte Loch Broom, in Rofs-foire, and thofe in the way between Loch-Broon and Loch-Mor $i$ abundantly, \&cc. I found it likewite upon a mountain call'd Ben-na-grion, in Strath, in the ille of Skye, two miles above $M^{\prime} K e n i c n^{2}$ C Caifle. 万. V. The branches of this fhrub trail flat upon the ground, two or three feet round the root, having a brown deciduous bark: the leaves grow a!ternate, of a long oval form, gradually diminifhing towards the bafe into a footitalk; they 
are wrinkled on the upper fide thro' the depreffion of the veins, and reticulated underneath by their prominency; their edges are nightly ferrated, and their footitalks have a few ftraggling hairs: the flowers grow in reflexed clufters at the fummits of the branches, each ftanding fingle upon hort peduncles : they are of an ovalconical form, and white color, the rim divided into five fhort, obture, reflexed fegments : the berries are globular, fmooth, with a deprefs'd umbilicus, black when ripe, and of the fize of a lloe, having five cells containing five feeds, their tafte fomething refernbling that of black currants.

«va ur $\sqrt{i} \approx$ : ARBUTUS caulibus procumbentibus, foliis integerrimis. Sp. pl. 566. (Oed. Dan.t. 33. Ger. Em. I 416. f. 5. Flor. Lapp. t. 6. f. 3. E' fig noft.) Bear-herries, Bear-whortle-berries. Anglis.

Braoileaga-nan-con. Gaulis.

Upon dry, heathy, mountainous and rocky places, throughout the Higblands and Weftern Ifles: it is fo common a plant that it is almoft needlefs to fpecify places. It abounds however at Dunkeld and Blair, the feats of the Duke of Atbol, in Pertbjhire.

To remove miftakes I muft here obferve, that this is the plant mentioned in Ray's Synopiss, p. 458, as found by Mr. Lbwyd, growing plentifully for fome miles together in that end of the ifland of Mill next to Y-Columb-kill; and not the ARBUTUS 


\section{DECANDRIA MONOGYNIA.}

BUTUS alpina, as I found by fearching the identical fpot where the firft grows in the greateit plenty, but not a fingle plant of the latter is to be feen. $h$. V.

The branches of this fhrub trail upon the ground two or three feet round the root, or more: the leaves grow alternate, are bluntly oval, intire on the edges, finely reticulated underneath, firm and evergreen: the flowers grow at the extremities of the branches in fmall clufters, each fupported by a fhort red footttalk : they are of an oval-conical figure, flefh-color'd, and divided into five obtufe, reflex'd fegments at the rim: the berries are round, with a deprefs'd umbilicus, fmooth and gloffy, red when ripe, and of the fize of a holly-berry, replete with an auftere mealy pulp, in which are five cells, containing five angular feeds. It may readily be diftinguifhed from the VACCINIUM vitis idea by it's trailing branches, and leaves not dotted, but reticulated underneath.

It is found in England as well as Scotland. I faw great abundance of it growing at the top of a wood call'd Eaft-Common.Wood, belonging to the Duke of Portland, about a mile from Hexbam, in Noribumberland.

The powder of the leaves taken fix or eight mornings in the quantity of half a drachm was not long fince a celebrated medicine for the ftone and gravel, but it is at prefent out of repute.

The whole plant is however found to be very ferviceable, 


\section{DECANDRIA MONOGYFIA.}

viceable, by means of it's aftringent quality, in tanning of leather: and the berries are a food for grous and other game.

\section{PYROLA. Gen. Pl. 554 .}

Cal. 5-partitus. Petala 5. Caps. 5-locularis, angulis dehifcens.

rorundifolia PYROLA ftaminibus afcendentibus, piftillo de1.

clinato. Sp. pl. 567. (Oed. Dan. t. I10. opt. Moris. bift. f. 12. $\therefore$ 10.f. I. ordinis fecundi. Ger Em. 408.f. 1.)

Common Winter-green. Anglis.

In dry woods not untrequent, and fometimes upon heaths. In the woods at Aucbendenny, and on the barks of the $C l y d e$, between the celebrated falls of Corus-Lyn, and Bonnotyne, near Lanerk, and in the woods at Blair, in Atbol, \&c. and upon the heatis above Dunkeld, amongt the ARB. uva urfl. \&xc. 24. VI!.

2wer 2. PYROLA foribus racemoris difperfis, ftaminibus piftillilq; restis. sp. pl. 567. (Oed. Dan. t. 55. opt.)

Leffer Winter-green. Anglis.

In fhady birch woods among the mofs. I obferv'd it in the ine of skye, in a wood on the fide of Ben-uz-Grion, near M'Kernow's Caftle, in Stratho and in a wood call'd Ca-bueh, facing the houfe of Mr. M'Konzie, of Dindonald, near LittleLoch-Broom, in Rofs-foire, and in the woods abous Lach-Ronnoch, in Perthilare, Sc. 2\%. VII. 
It is extremely like the preceding, but may readily be diftinguifhed by the ftamina and ftyle growing erect. The ftalk is triangular in both fpecies.

fecunda 3. P. racemo unilaterali. Sp. pl. $5^{6} \sigma_{-} \cdot\left(\mathrm{O}_{e} d\right.$. Don. $t$. 402. opt. Moris. bift. S. 12. t. 10.f. 4.ordinis inferioris. Ger, Em. 408. f. 2.)

Dented-leav'd Winter-Green. Anglis.

In thady birch woods among the mofs with the preceding, near Little-Loch-Broom, in Rofs-ßBire, and about Locb-Mori, in the fame county, and in the birch-woods of Trofcbraig, Craig-ioifgt, and Coille-mbor, about Loch-Ronnoch, in PertbBire, where all three fpecies are found. 24 . VIt. The leaves are elliptical, acute and ferrated: the flowers grow all on one fide of the ftaik: the antheræ ftand out beyond the rim of the corolla, and the ftigma beyond the antheræ.

All the pyrolæ are aftringent and vulnerary, but are rarely ufed in the prefent practice.

\section{I) I $G \quad Y \quad N \quad I A$.}

CHRYSOSPLENIUM. Gen. pl. 558.

Cal. 4-s. 5.fidus, coloratus. Cor. o. Caps. 2-roftris, I-locularis, polyfperma.

alternifoli- CHRYSOSPLENIUM foliis alternis. $s p . p l .560$. unit.

(Oed. Dan. t. 366. opt. Moris. bift. S. 12.t. S. f. 8. Pet. berb. t. 6.f. 10.)

Alternate-leav'd Golden Saxifrage. Anglis.

By the fides of fountains and rivulets, but not common. 
common. I obferv'd it at the foot of fome high moift rocks in the Duke of Argyle's park at Rofenatb, growing with the C. oppofitifolium, and Dr. Parfons found it by the ditches in the woods at Mecvis-Bank, near Dalkeitb. 4. IV.V. The firft or primary flower is quinquefid, and has 10 famina; the others are quadrifid, and have only eight. vid. Pbilosoph. Botan. p. 123.n. 178. The ftalk is pellucid, fucculent, and branched towards the top: the leaves kidney thap'd, crenated, thinly hairy, and grow aiternate on long foctitalks : the branches are dichotomous: the fiowers grow in a flat feffile umbel, yellow and fhining: the feeds are black when ripe.

oppofitifoli- CIIRYSOSPLENIUM foliis oppofitis. Sp.pl. 56 g.

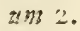

(Oed. Den. t. 365. opt. Moris. bift. S. 12.t.8.f. 7. Ger. Enn. 841.f. 2. Pet. berb. t. 6.f. g.)

Common Golden Saxifrage. Anglis.

By the fries of fountains and rivulets in thady places frequent. 2 . IV. V.

It is extremely like the preceding, but the leaves grow oppolite, and are fmaller.

\section{SAXIFRAGA. Gen. Pl. 559 .}

C.36. 5-partitus. Cor. 5-petala. Caps. 2-roftris, Ilocularis, polyfperma.

* Foliis indivifs, coule fubmudo.

felteris 1. SAXIFRAGA foliis ferratis, caule nudo ramofo, petalıs acuminatis. $S p . p l .57^{2}$. (Oed. Dan. t. 23 . opt. Scopoli Flor. Curniol. t. 13. n. 492. bona. 
Moris. bift.f. 12.t. 9. f. 13. Pluknet.t. 58.f. 2. E t. $\left.222 . f .4_{0}\right)$

Starry Saxifrage, or Hairy Kidney wort. Anglis. Upon the fides of rivulets, and upon moift rocks near the fummits of the highland mountains, very common. It grows upon Ben-Lomond, from about half way up quite to the fummit; and the fame very nearly of mott other high mountains. 4. VII.

The leaves are elliptical, or bluntly oval, intire at the lower part of their edges, but have generally five or feven dents about their extremities. They grow in tufts, and are commonly hairy; from the centre of each tuft arifes one naked ftalk, branched towards the top: the fegments of the calyx are reflex'd: the petals white, and acute, with two yellow fpots at their bafe: the antheræ are red: the germen flefh-color'd.

nivalis 2: SAXIFRAGA foliis obovatis crenatis fubfeffilibus, caule nudo, floribus congeftis. $s p . p l$. 573. (Oed. Dan. t. 28. Raj. Syn. p. 358. t. 16.f. 1. magna. vid. fig. noft.)

Clufter Hower'd Alpine Saxifrage. Anglis.

Upon the fummits of the highland mountains, but not common Upon the Eaft fide of Craigcboilleach, above Finlalrig, in Ereadalbane. Mr. stuart. 24. VI. VII.

The leaves are red underneath, and at their tips: the ftalk is about three inches, red and hairy, fometimes a little branch'd, fometimes not at 
all : the flowers grow in clufters, fmall, of a white or pale red color, with red piftils.

** Foliis indivifis, coule foliojo.

sppofitifo- S. foliis caulinis ovatis oppolitis fubimbricatis; lia 3 . fummis ciliatis. sp. pl. 575. (Oed. Dan. t. 34 . Moris. bift. S. 12. t. 10.f. 36. Flor. Lappon.t. 2.f. 1. Pct. herb. t. 6i.f. g.)

Mountain heath-like Saxifrage. Anglis.

Upon the rocks of the highland mountains frequent, as upon Ben-Lomond, \&c. \&c. and upon the mountains in the iflands of Rum and Skye. 4. V.

The ftalks are numerous, weak, and filiforme, trailing upon and hanging over the edges of the rocks: the leaves are oval, ftiff, and ciliated, growing oppofite to each other, feflile, and imbricated quadrangularly : the ftalks are terminated each with a fingle feffile flower, of a bright purple color, turning blue as it goes off, having a ciliated calyx. It makes an elegant appearance when in flower.

Gutumnalis $S$. folis caulinis linearibus alternis ciliatis, radicalibus aggregatis. Sp.pl. 575. (Oed. Dan.t. 72 . opt. Scopol. Flor. Carniol. t. 14. n. 493. bona. Moris. bift.f. 12. t. 6.f. 3. ordinis secundi ad dextram. Pet. berb. t. 6r.f. 10. Ger. Em. 516.f. 2.) Yellow Autunnal Saxifrage. Anglis.

Upon moift rocks, and by the fides of rills amongft the highland mountains abundantly. It frequently 
quently grows by road-fides, even at the foot of them, as at the pafs of Killicranky, near Blair, \&c. 4. VII. VIII.

The root throws out feveral trailing furculi : the ftalks are fix or eight inches high, reclining at the bafe: the leaves are of a narrow elliptical form, acute, feffile, alternate, and generally a little ciliated on the edges, though fometimes fmooth: the flowers grow at the top of the ftalk, one or two upon a peduncle, in number from four to ten, or a dozen : the petals are elliptical, yellow, generally dotted with faffron-color'd fpots, and grow expanded and plane: the fegments of the calyx are of the fame length as the petals, and grow open and flat.

That this is the fame plant which Linneus calls Saxifraga aizoides, growing in Sweden and Lapland, there can be no doubt, from the defcriptions and figures of authors: we chufe therefore, with Jacquin and Haller, to confider them both as one fpecies, and adopt the trivial name of autumnalis as well fuited to both. The plant growing upon Knotsford moor, in Che/bire, mentioned by Ray and Hudfon, and fuppofed by the latter to be the S. autumnalis, of Linneus, we have feen, and found to be the S. birculus of that author, figur'd in Oed. Dan. t. 200. E' Hall. Stirp. Helvet. vol. I. p. I40.t. II.

*** Foliis lobatis, caule erecto.

gramulata 5 SAXIFRAGA foliis caulinis reniformibus lobatis, caule 
caule ramofo, radice granulata. $S p . p l .5 ; 6$. (Oed. Dan. t. 514. Moris. bift. S. 12. t. 9. f. 23 , Ger. Em. 84r.f. r.)

White Saxifrage. Anglis.

About Salifbury-Craigs, and the hills in the King's Park. Dr. Parfons. And plentifully upon the banks of the Clyde, at Corus-Lyn, near Lanerk, \&c. 4. V.

The root confifts of a clufter of tubercles, intermix'd with fibres: the leaves are a little hairy, the radical ones ftanding on long footftalks: the ftalk is a foot or eighteen inches high: the peduncles and calyx are a little hairy and vifcid: the petals are large, bluntly oval, white, and finely ftreak'd with green veins.

tridactylites 6.

SAXIFRAGA foliis caulinis cuneiformibus trifidis alternis, caule erecto ramofo. Sp.pl. 578. (Moris. bift. .. 12.t. 9. f. 31. opt. Ger. Em. 624.f. 2, Pet. berb.t. 6I. f. 8.)

Rue-leav'd Whitlow-grafs, or Saxifrage. Anglis. Upon rocks and walls, but rare. Sibbald. $\odot . I V$. The ftalk grows from one to four inches high, erect, branched, red and vifcous : the radical leaves have long footitalks; thofe on the ftalk are nearly feffile: the peduncles arife from the alæ of the leaves, generally bearing one flower, fmall and white.

*** Foliis lobatis, caulibus procumbentibus.

bunnides y S. foliis caulinis linearibus integris trifidifve, ftolonibus 



$$
b \text { - }
$$
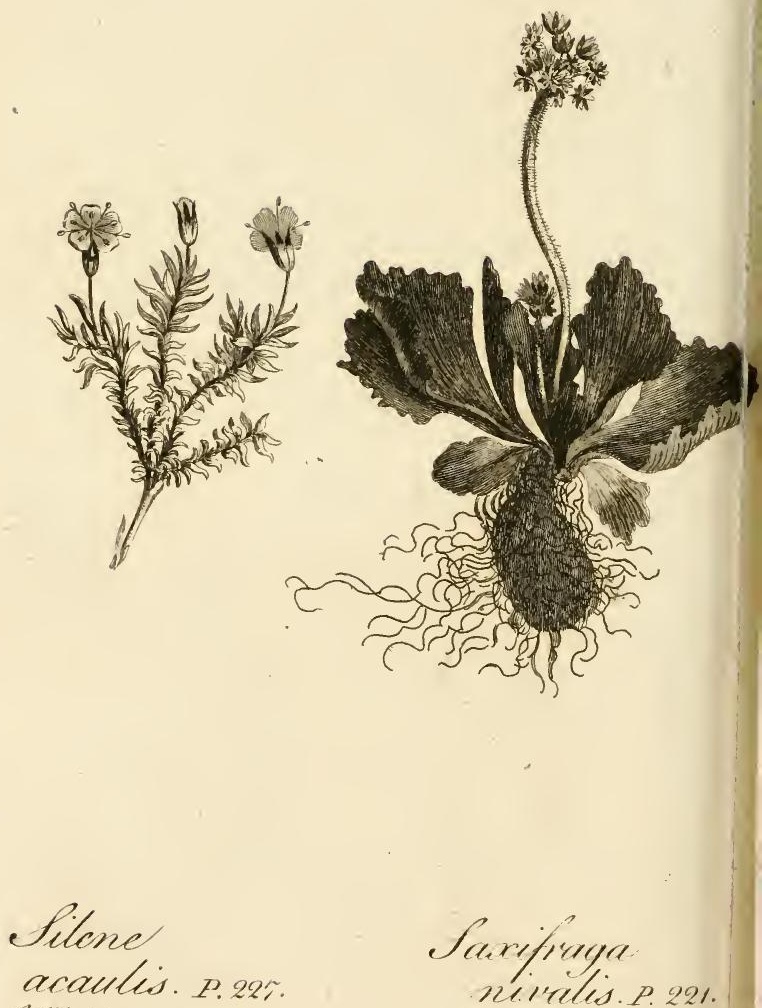
nibus procumbentibus, caule erecto nudiufculo, sp.pl. 579. (Oed. Dan. t. 34\%. Moris. bift. S. I 2. t. g.f. 26. bona.)

Mors Saxifrage. Anglis.

Upon the rocks in the highlands very common. 4. V.

The trailing offsets of the roots form a complete curhion: the intire leaves, and the lobes of the trifid ones, are fharply pointed: the petals are white, with yellow ungues, growing a little erect, obtufe, or flightly emarginated.

\section{SCLERANTHUS. Gen. pl. 562 .}

Cal. I-phyllus. Cor. nulla. Sem. 2, calyce inclufa. znuus I. SCLERANTHUS calycibus fructûs patulis. Sp. pl. 580 . (Oed. Dan. t. 504. Pet. berb.t. 9.f. 7.) Annual Knawel, or German Knot-grafs. Anglis. In corn fields frequent. $\odot$. VII.

\section{DIANTHUS. Gen. pl. 565 .}

Cal. cylindricus, I. phyllus; bafi fquamis 4. Petaia 5, unguiculata. Caps. cylindrica, I-locularis. * Flores folitarii, plures in eodem caule.

teltoides I. DIANTHUS floribus folitariis ; fquamis calycinis lanceolatis binis, corollis crenatis. $S p . p l .588$. (Pet. berb. t. 56.f. 2. Ger. em. 593.f. 6.) Maiden Pinks. Anglis. In the king's park at Edinburgh. 4. VII.

laucus 2. D. florihus fubfolitariis; fquamis calycinis lanceoQ latis 
latis quaternis brevibus, corollis crenatis. $S p \cdot p l$. 589. (Dillen. Iltham. 400. t. 298.f. 348.)

Double-color'd Maiden-Pink. Anglis.

In the king's park at Edinburgh. 24. VII.

The flower is white, with a purple eye; in other refpects it differs very little from the preceding. * Caule uniflora berbaceo.

arenorius 3 D. caulibus fubunifloris; fquamis calycinis ovatis obtufis, corollis multifidis, foliis linearibus. $S p$. pl. 539. (Moris. hijt. S. 5: t. 25. f. 11 . Ger. em. 594. t. 12.)

Single-flower'd Rock-Pink. Anglis.

Upon a hill near Pertb? Sibbald. 4. VII.

\section{T \\ CUCUBALUS. Gen. pl. 566.}

Cal. inflatus. Petala 5 , unguiculata, abfque corona' ad faucem. Caps. 3-locularis.

Beken I. CUCUBALUS calycibus fubglobofis glabris reticulato-venofis, capfulis trilocularibus, corollis fubnudis. Sp. pl. 59 I. (Moris. bifi. S. 5.t. 20. f. 1. Ger. em. 678.f. 2.)

Bladder Campion. Anglis.

In corn fields and dry paftures frequent. 4 . VII.

$$
\text { SILENE. Gen. pl. } 5^{6} 7 \text {. }
$$

Cal. ventricofus Petala 5, unguiculata; coronat: ad faucem. Caps. 3-locularis. 
amena 1. SILENE petalis bifidis; coronula fubcoadunata, floribus fecundis, pedunculis oppofitis trifloris, ramis alternis. Sp. pl. 596. (Moris. bift. S. 5. $t$. 20.f. 2. Pet. berb. t. 57.f. 1. Ger. em. 469. f. 2. omnes floribus nimis parvis.)

Sea Campion. Anglis.

On the fea beach in ftoney places frequent, as at Fast-Caftle, on the coaft of Berwickfire, \&c. \&c. The Craig of Ailfa, off the coaft of Airfbire, abounds with it, \&c. 4. VI. VII.

The ftalks recline upon the ground: the branches grow alternate and divaricated: the leaves are of an oval-lanceolate form, glaucous, and fmooth on the upper fide : the flowers all tend one way : the peduncles are oppofite to each other, and fupport three flowers: the calyx has ro reddifh angles, a little hairy: the petals are white and bifid: the antheræ of a dark-grey color. It approaches very near to the cucubalus Beben, but the flower is more fpecious, and the ftalks are decumbent.

acaulis 2. SILENE acaulis depreffa, petalis emarginatis. Sy/t. Nat. 311. Sp. pl. 603. (Oed. Dan. t. 27. opt. Dillen. Eltham. 206. t. 167.f. 206. Ger. em. 593. f. 8.)

Mofs-Campion. Anglis.

Upon the highland mountains in many places, as upon Ben.Lomond, about half a mile from the top, in abundance with the Sibbaldic; upon CragChailleach, in Breadalbane, and upon the moun- 
tains about Locb-Rannoch, in Atbol, \&cc. I obferv'd it likewife upon the mountains about Locb-Urn, in Invernefsfoire, and upon the mountains of Rum. 24. VII.

The roots are thick, and grow together in a mat: the leaves are extremely narrow, linear and acute, growing in tufis: the ftalks are about an inch high, having generally two leaves growing oppofite upon it, and bearing a fingle flower: the calyx is of a dark red, and the flowers of a bright pink color, which enlivens the barren mountains exceedingly.

\section{STELLARIA. Gen. pl. 568.}

Cal. 5-phyllus, patens. Petala 5, bipartita. Caps. I-locularis, polyfperma.

nemorum I. STELLARIA foliis corciatis petiolatis, panicula pedunculis ramofis $S p$. pl. 603. (Oed. Dan. t. 27 1. opt. Moris. bift. $\int .5 \cdot t .23 \cdot f \cdot 2$. Column. Ecph. I. p. 290. t. 290.)

Broad-leav'd Stichwort. Anglis.

In woods and fhady places, frequently in the lowlands, as about Broombolm and Langbolm, in Efkdale, and at springkeld and Hoddam-Cajtle, in Annandale, abundantly: obferv'd alfo by Dr. ParSons, at Meavis-Bank. 24. V. VI.

The ftalks are about a foot or eighteen inches high, branch'd in a panicle at top : the leaves are heartfhap'd, acute, hairy, of a much paler green on the under fide than the upper; the lower ones fupported by footftalks, which are hairy and channel'd; 
channel'd; the upper ones feffile: the calyx is erect, a little hairy, and white on the margins : the petals bifid, almoft to the bafe: between the longer ftamina and the calyx is a fmall glandular nectarium.

Holoftea 2. STELLARIA foliis lanceolatis ferrulatis. Spec. pl. 603. (Ger. em. 47. Pet. herb.t. 58.f. 1.)

Greater Stichwort. Anglis.

In woods and hedges common. 24. V.

The petals are nearly twice the length of the calyx, and divided half way to the bafe.

graminea 3 S. foliis linearibus integerrimis, floribus paniculatis. Sp. pl. 604. (Oet. Dan. t. 414 E var. t. 415. Pet. berb. t. $\left.5^{8} \cdot f \cdot 3.\right)$

Leffer Stichwort. Anglis.

In dry paftures frequent. 4 . VII.

$\beta$ There is a variety of this with fmooth oval feffile leaves, and few flowers, growing often in wet marhy places, vide Pet.berb.t. 58.f. 4 E Moris kift. .5. 5. t.23.f. 8. Ger. en. 6r3.f. 8.

Bog Stichwort. Anglis. 24. VII.

The ftalk is quadrangular: the petals fcarcely longer than the calyx, and bifid to the bafe.

ARENARIA. Gen. pl. 569 .

Cal. 5 phyllus patens. Petala 5, integra. Caps. I-locularis, polyfperma.

peploides r. ARENARIA foliis ovatis acuis carnolis. Sp. pl.

Q 3

$60 \%$ 
605. (Las. PruJf. 12.t. 2. Ger. t. 622.f. 1. Pet. berb.t. 65.f. g.)

Sea Chickweed. Anglis.

Upon the fea coaft in fandy foils frequent, as upon the coaft by Leith, \&c. 24. VII.

The leaves are fmooth and oppofite, and grow fo clofe together at the tops of the ftalks as to make them appear quadrangular.

trinervia 2 ARENARIA foliis ovatis acutis petiolatis nervofis. Sp. pl. 605. (Oed. Den. t. 429. opt. Pet. berb.t. 59. $f$. 1.)

Plantain-leav'd Chickweed. Anglis.

In fhady woods, \&c. as at Meatis-Bank and Dunglass-Den. Dr. Parjons. $\odot$. VI.

The ftalk is dichotomous : the peduncles weak and deflex'd: the capfules pendulous.

jerpyllifolic A. foliis fubovatis acutis feffilibus, corollis calyce 3. brevioribus. Sp. pl. 606. (Pet. berb. t. 59.f. 2. Ger. en. 6i2. $f \cdot 3$.)

The left Chickweed. Anglis.

Upon walls and other diry barren places, $\odot$. VI.

rubra 4 .

A. foliis filiformibus, ftipulis membranaceis vaginantibus. Sp.pl. 606. (Loes. Pru/J. 203. t. 63.60na. Pet. berb. t. 59.f. 8.)

Purple-flower'd Chickweed, or Spurrey. Anglis. In gravelly foils frequent. Dr. Parfons. ๑. VI.

marina $\beta$. There is a variety of this common on the fea coafts, much 
much larger in all its parts, and with fucculent leaves. vid. Pet. berb. t. 59.f.7. E Moris. bift. f. $5 \cdot$. $.23 \cdot f \cdot 15$.

Furple Sea-Spurrey. Anglis. $\odot$. VI.

The branclies of both trail on the ground, and the flowers are purple, opening at nine o'clock in the morning, and Thutting between two and three in the afternoon. The calyces of the firft are hairy and vifcid.

verna 5. A. foliis fubulatis, caulibus paniculatis, calycibus acuminatis ftriatis. Syft. nat. 3'3 E Mantifs. 72. (V aill. Paris. t. 2 f. 3 . bona, quippe calyces acuminali, ton ovati oltufi, ut A. faxatilis. (fynt. nat. $3 \mathrm{I}_{3}$ ) requirit. Gerord. Flor Gallo-prowin. $t$. ;5. f. I \& defcriptio congruunt. Herm. parka $t$. 12)

Vernal Mountain Chickweed. Anglis.

Upon mountainous paftures, as upon Artbur's Jeat, \&c. 24. V. VI.

The root throws out numerous branches about three or four inches high, reclining a little at the bafe, but afterwards erect: the leaves are fo crouded about the roots as to form tufts; they are fmooth, linear, fubulate, a little ftiff, and ftriated underneath with three ribs: two or three pairs grow on each ftalk, oppofite, and connate at their bafe; the uppermolt pairs are horteit and wideft, the lowermoft have their points bent on one fide of the ftalk: the flowe:s grow upon the top of the ftalks, and from the alx of the leaves, one 
upon a peduncle, and generally about three in all, tho' the number varies from one to five or fix: the ftalk, peduncle and calyx are all nightly hairy : the leaves of the calyx are lanceolate, acuminated, and ftriated each with three ribs: the petals are oval, white, and a little longer than the calyx.

laricifolia 6 ARENARIA foliis fetaceis, caule fuperne nudiufculo, calycibus fubhirfutis. Sp. pl. 607. (Magnol. Hort. Monsp. t. I1. Scopol. Flor. Carniol. t. 19. 21.54 1. melior.)

Larch-leav'd Chickweed. Anglis.

On dry mountainous paltures in a ftoney foil. I obferv'd it upon Caftle bill, near Forfar, in the county of Angus. 24. VIII.

It differs very little from the preceding, only from the ala of the leaves arife clufters of other fmall leaves, which are nothing elfe but the rudiments of young branches; to which may be added, that it bears fewer flowers upon a ftalk, and the petals are fmaller.

\section{CHERLERIA. Gen. pl. 570.}

Cal. 5 phyllus. Nectaria 5 emarginata, petaloidea. Petala nulla (nifi calycem vel Nectoria velis.) Anthere alterna fteriles. Caps. 3-locularis, 3-valvis. fedoides I. CHERLERIA. $s p$. pl. 608. (Haller, firp. Helvet. vol. 2.p. 114.t.21. Opufc.p.301. t. 1. cadein ह? fig. maft.)

Molfy Cherleria. Anglis. 
Upon the highland mountains near their fummits, and by the fides of rills in feveral places, as upon Ben-tefkerny and Ben-challum, two mountains to the wett of Locb-Tay, in Breadalbane, plentifully; and upon a mountain in Rum, called Baikeval, \&c. 4. VII. VIII.

It forms large green mofly tufts: the ftalks are about two inches high, clofely matted together, and covered with crowded leaves, growing oppofite to each other, of a narrow linear acute form, and firm texture, and a little rough on the edges: the flowers grow out of the fummits of the branches, fingle, erect, and on very fhort peduncles, of a yellowifh green color: the leaves of the calyx are of an oval lanceolate form, and Atreak'd on the back with three lines: the nectaria are much fhorter than the calyx, and heartfhap'd: the whole plant, at firft view, has a great refermblance to a tuft of the female Poly. tricbum commune, or fome fpecies of mium.

It has never yet been difcover'd in England, but is peculiar to alpine countries.

\section{PEN T A G Y I A. \\ COTYLEDON. Gen. pl. 578 .}

Cal. 5-fidus. Cor. I-petala. Squama nectariferæ 5, ad bafin germinis. Caps. 5 .

umbilicus veneris. $\mathrm{I}$.

COTYLEDON foliis cuculato-peltatis ferratodentatis alternis, caule ramofo, floribus erectis.

$s_{p}$. 
sp. pl. 615. (Ger. em. 528. f. I. Moris. bift. S. 12.

t. 1o. $f$. 4. ordinis Secundi.)

Navel-wort, Kidney-wort, or Wall Penny-wort. Anglis.

Upon rocks and old buildings. I obferv'd it upon the rocks of Drummadoon, on the Weft fide of the Ine of Arran, and upon the craig of Ailfa abundantly, and upon the ruins of $Y$-columb-kil, \&c. 24. VI.

\section{SEDUM. Gen. pl. 579 .}

Cal. 5-fidus. Cor. 5-petala! Squame nectariferæ 5, ad bafin germinis. Caps. 5 .

$$
\text { * Planifolia. }
$$

telepbitm I SEDUM folis planiufculis ferratis, corymbo foliofo, caule erecto. Sp. pl. 6i6. (Ger en. 520. f. I. Moris. bift. f. 12. t. 10. f. 1. E 2. ordinis Juperioris.

Orpine or Live-long. Anglis.

By the road fide going to Dumbarton from Glefgow, on the right hasd upon a rock. Dr. Parfons obferv'd it alfo about two miles eaftward of Dumlarton, under hedges. 2. VIII.

** Teretifolia.

reflexum 2. SEDUM foliis fubulatis fparfis bafi folutis; inferioribus recurvatis. Sp. pl. 618. (Ger. em. 512.f. I E. 513.f. 6. Moris. bift. S. 12. t.6.f. 6 हٔ 7. Pet. berb.t. $42 . f .5$ Eं 6)

Yellow reflex'd Stonecrop. Anghis. 
Upon houfes and walls. Sibbald. Dr. Parfons obferv'd it in a village going from Edinburgb to - Lord Marcb's. 4. V1I.

The leaves are femicylindrical, glaucous, fucculent and acuminated: in Holiand fometimes eaten in fallads.

acre 3.

S. foliis fubovatis adnato-feffilibus gibbis erectiurculis alternis, cyma trifida. \&p.pl.6ig. (Ger. em. 517. Moris. bift. J. 12. t. 6. f. 12. Pet. berb. $t$. 42. $f .9)$

Pepper-Stonecrop, Wall Pepper. Anglis.

Upon rocks and barren ftoney places, but not very common. I obferv'd it in the inland of Lamlaß, on the fouth-ealt of Arran. 24. VI.

The flowers are yellow, and the leaves clofely inbricated, fo as to make the ftalks appear cylindrical. It is acrid, and biting to the tafte.

The juice of it externally is recommended in ulcerous fores and cancers: taken internally it operates ftrongly as an emetic and cathartic. An ounce of it, boil'd in twelve ounces of ale, and taken in four dofes, has been found ferviceable in the dropfy.

rubens 4 .

S. foliis ovatis fefrilibus gibbis alternis, cyma trifida, capfulis rubentibus. (Oed. Dan. t. 82. opt. Raj.Syn. p. 326.t. I 2.f. 2)

Red Stonecrep. Anglis.

On walls and rocks frequent, as about the old college 
lege of Lincluden, near Dumfries, and upon the walls by the fide of the Clyde, at Rofeneatb; upRofs-Ifland, in Locb-Lomond, and numberlefs other places. $\odot$. VI. VII.

From one root arife feveral branches, which recline at their bafe, but afterwards grow erect about two inches high: the leaves are oval, gibbous, obture, leffile, alternate, fmooth, and crouded clofe together at the fummits of the unflow'ring branches, but more ditant in the flow'ring ones. This, together with the unfolded Cyma, makes the tops of the young branches bigger than the bottom, like an inverted cone. The Cyma, or little umbel, which terminates the branches, is generally trifid, and confifts of an uncertain number of flowers from three to nine, ftanding either on very fhort peduncies, or quite ferile. The petals are acute, of a pale fieth color, with a red Carina. The germina are of a bright red. The ftamina ten, five arifing from the bafe of the petals, and five between them, with red $A n$ thera. The whole plant is fmooth and reddifh in decay.

It is defcrib'd by Haller in his Stirp. Helvet. n. $96_{3}$, but cannot properly be referr'd to any fpecies of Linnaus. The fedum annum of Linnaus he himfelf informs us, bears a yellow flower. Flor. Jucc. p. 154. E Mantiss. p. 389 ; it cannot therefore be that. And the fedum rubens. Sp. pl. 619, has but five ftamina, which has ocafioned him in his 
Syft. nat. (p.317 \& 226) to reduce it to the $\mathrm{Ge}$ mis of Crafjula. Unlefs, therefore, our plant varies in the number of ftamina, it cannot with any propriety be referr'd to his craflula rubens, tho' it may to fome of the mifapply'd fynonyms.

cillofum 5. SEDUM caule erecto, foliis planiufculis, pedunculifque fubpilofis. sp. pl. 620. (Ocd. Dan.t. 24 . opt. Ger. en. 5i6. f. 1. Moris. bift. S. 12. t. 8.f. 48.)

Marh Stonecrop. Anglis.

On bogs and moift rocks by the fides of mountains, as on Pentland-Hills, Dr. Parfons : and in GlenEglas, in Stratb-Eme, to the fouth of Crief, \&c. Mr. Stuart. ๑. VI.

The ftalk is erect, four or five inches high, branch'd at the top, downy and vifcid : the leaves grow alternate and diftant, oblong, thick, convex on the outfide, and obtufe : the flowers grow in a thin branched umbel, at the top of the ftalk, upon vifcid peduncles: the calyx is downy and vifcid: the petals are oval and acute, of a red color, with a hairy Cerina of a deeper red.

\section{OXALIS. Gen. pl. 582 .}

Cal. 5-phyllus. Peta!a unguibus connexa. Caps. angulis dehifcens, 5-gona.

acetofella I OXALIS fcapo unifloro, foliis ternatis, radice fquamofa articulata. Sp. pl. 620. (Miller. icon. 
195. f. 2. Ger. em. 1201. f. 1. Pet. berb. t. 63. $f .7)$

Wood Sorrel. Anglis. Gouke-meat. Scotis.

Biadh-eunain, feada-coille. Goulis.

In woods frequently. At the hermitage, \&rc. Dr. Parfons. 4. V.

The leaves are radical only, and numerous; three grow together at the top of one common footftalk, heart-hap'd, hairy, their points all meeting in a centre, and endued with a degree of fenfibility, for when fruck or handled they droop. Linnous fays they are expanded in moift rainy weather, and contracted in dry. The flowers are white, elegantly marked with red veins, have yellow Ungues, and grow fingly upon radical footitalks.

The whole plant has an agreeable acid tafte, and cooling quality, and is recommended in malignant fevers, and for the fcurvy. In the inland of Arran I was informed that a whey or tea of it was ufed in putrid and other fevers, with good fuccefs.

AgROSTEMMA. Gen. pl. $5^{8} 3$.

Cal. I-phyllus, coriaceus. Petala 5, unguiculata; Limlo obtufo indivifo. Caps. I-locularis.

gitbego :. AGROSTEMMA hirfuta, calycibus corollam æquantibus, petalis integris nudis. $S p \cdot p l .624$. (Ger. em. 1087. Moris. lift. f. 5. t. 21.f. 31. Pet. herb. t. 57.f. 12)

Cockle. 
Cockle. Anglis.

In corn fields. $\odot$. VI.

The italk is two feet high, erect, but little branch'd and hairy: the leaves linear, acute and hairy: the fegments of the calyx hairy ftriated, and rather longer than the corolla: the petals obtufe, and of a bright purple color: the feeds black, and elegantly rough, having a white meal or flour.

\section{LYCHNIS. Gen.pl. 584 .}

Cal. I-phyllus, oblongus, lævis. Petala 5, unguiculata. Limbo fubbifido. Caps. 5-locularis.

fios cuculi I LYCHNIS petalis quadrifidis, fructu fubrotundo. Sp. pl. 625. (Ger. em. 600. f. 1. Moris. bift. f. 5 . t. 20.f. 8. Pet. berb. t. 56.f. 6)

Meadow Pinks, Wild Williams, Cuckow Flower, or Ragged Robbins. Anglis.

In moift meadows and wet boggy places frequent. 24. VI.

The ftalk is angular, and red at the joints: the leaves reflex'd on their edges, and red at their ends : the calyx ftreak'd with ten red prominent lines : the petals red and quadrifid or jagged. Cattle refufe to eat it.

:ifcaric 2. LYCHNIS petalis fubintegris. Syft. nat. 319. Sp. pl. 625. (Ger. em. 60I. f. 3. Moris. bift. S. 5.t. 20.f. 6. Pet. berb. t. 57.f. 8)

Red Catchlly. Anglis. 


\section{DECANDRIA PENTAGYNIA.}

Upon the rocks at the hermitage near Edinburgh. Dr. Parjons. 4. VI.

The flowers are red, and grow in a panicle, compofed of oppofite vifcid branches.

dioica 3. L. floribus dioicis. Sp.pl.626. (Ger. em. 469.f. I. Moris. bift. f. 5:t. 2 r.f. 2 I E 23. Pet. berb. t. $57 . f .5$ \& 6$)$

White Campion, the ferrale.

Red Campion, the male. $\}$ Anglis.

In wooks and hedges. 24. VI.

The rocks in the inland of Ailfa are cover'd with the red-flower'd only.

CERASTIUM. Gen. pl. $5^{8} 5$.

Cal. 5-phyllus. Petaia bifida. Caps. I-locularis, apice dehifcens, 10-dentatus

* Copjulis oblongis.

vulgatum I CERASTIUM foliis ovatis, petalis calyci æqualibus, caulibus diffufis. Sp.pl. 62\%. (Vaill. Paris. t. 3o. f. 3. Pet. berb.t. 58.f. 5)

Common Moure-ear Chickweed. Anglis.

In corn fields, paftures and by way-fides. $\odot$.VI.

Many reclining falks arife from one roor, forming a thick tuft before they flower: the leaves are of a round oval form, the upper ones more acute. It flowers later than the following, and lafts longer.

vifcofum 2. C. erectum villofo-vifcofum. s.pl. 627. (V cill. $t$. 3०. f. 1.)

Upright 


\section{DECANDRIA PENTAGYNIA.}

-Upright Moufe-ear Chickweed. Anglis.

The ftalks are a foot high, erect, not fo numerous from one root as the preceding, and the leaves more acute.

In meadows and paftures frequent: $\odot . I V . V$.

fenidecandrum 3.

ervenfe 4.

CERASTIUM floribus pentandris, petalis emarginatis. Sp. pl.627. Vaill. Par. t. 3०.f. 2. Raj. Syn. p. 348. t. 15.f. 1. bona)

The left Moufe-ear Chickweed. Anglis.

Upon the hills about Artbur's Seat. Dr. Perfons. $\odot$. V.

It is about three inches high, commonly fingle at the root, and very little branch'd at the top : it has only five fertile Stamina, but fometimes five other barren ones are vifible, without Anthere.

C. foliis lineari-lanceolatis obtufis glabris, corollis calyce majoribus. Sp. pl. 628. (Voill. Paris. t. 30. f. 4 E' 5. bona. Ger. em. 595.f. 15)

Narrow leav'd Moufe-ear Chickweed. Anglis.

In paftures of a gravelly foil, but not common. I obferv'd abundance of it at the foot of walls up= on the borders of Scotlind, near Work, not far from Keljo. 4. V. VI.

The ftalks are weak and reclining: the leaves not always fmooth, but moft commonly a little hairy: the petals are twice as long as the calyx, which readily diftinguifhes the fpecies.

** Capfulis fubrotundis.

$\mathrm{R}$

C. folits 
latifolium 5 C. foliis ovatis fubtomentolis, ramis, unifloris capfulis globofis. Sp. pl. 629. (Haller. Strīp. Helvet. n. 887. Marten. Spilzberg. t.G.fig. d.)

Woolly Moufe ear Chickweed. Anglis.

Upon the rocks on the fummits of the highland mountains, as upon Ben-Lomond, and the mountains about Glenco, \&cc. 2. VI. VII.

The roots are white, tough and woody, throwing out numerous reclining branches, which afterwards grow erect to the height of about three inches, bearing one, or at moft two fowers: the leaves are oval, crouded together in the young branches, and all extremely woolly. If two flowers grow upon the fame ftalk, the peduncle of one is divaricated, or grows fo diftant from the other as to form with it an angle almoft equal to a right angle. The calyx is woolly, the petals larger than the calyx, the capfule round at firlt, but afterwards lengthen'd out into a curv'd horn. Haller's defcription of this plant agrees precifely with ours; and Marten's figure above quoted, tho' a bad one, refembles it; but neidefcriptions nor figures of the C. alpinum correfpond as they ought, that being either fmooth or only a little hairy, and producing fix or eight flowers upon a ftalk. We therefore conclude ours to be moft reducible to the C. latifolium Lin. aquaticun 6 CERASTIUM foliis cordatis fefflibus, floribus,
folitariis, 


\section{DECANDRIA PENTAGYNIA.}

folitariis, fructibus pendulis. Sp.pl. 629. (Ger.

emac. 6r 1.f. 1. Mentzel. pug. t. I. f. 3)

Marh Moufe-ear Chickweed. Anglis.

By the fides of ditches and rivers, but not frequent. 24 VII.

The ftalk is a yard high, or more, nearly quadrangular, branched, weak, flightiy hairy, and unable to fupport itfelf: the lower leaves have ciliated footltalks, the upper ones are feffile, and Aightly hairy, with a little vifcidity : the flowers grow near the fummits of the ftalks from the Ale of the leaves, and from the divifions of the branches, fingly upon vifcid peduncles: the calyx is hairy and vifcid, the petals twice as long as the calyx, and the capfules pendulous.

\section{SPERGULA. Gen. pl. 586.}

Cal. 5-phyllus. Petala 5, integra. Caps. ovata, I-locularis, 5-valvis.

arienfis I. SPERGULA foliis verticillatis, floribus decandris. sp.pl.630. (Ger. em. 1125. f. 3. Pet. berb.t.59. $f .6)$

Corn-Spurrey. Anglis. In corn-fields frequent. $\odot$. ViII.

The leaves are round, linear, and furrow'd, from e ght to twenty in a whirl: the calyx hairy and vifcid, the peduncles branch'd, the petals white, the ftamina vary from five to ten, the capfules are pendulous, and the feeds black, and furrounded with a membranaceous ring. 
In Holland and Germany it is fown in the fields as a fodder for cattle.

nodofa 2. S. foliis oppofitis fubulatis lævibus, caulibus fimplicibus. Sp. pl. 630. (Oed. Dan. t. 96. opt. Loes. Flor. Pruf. p. 204. t. 64. bona. Pet. herb. t. 59. f. 5. Ger. em. $567 \cdot f \cdot 6$. Plukenet.t. 7.f. 4)

Knotted Spurrey. Anglis.

In wet paftures, and on the fides of lakes and marfhes, but not very common. 24. VIII.

Several ftalks arife from one root, fometimes reclining and fometimes erect, and about three or four inches high : the leaves are fmooth, of a fine green, and from their bofoms towards the top of the fallis appear little knots of other leaves, which are the rudiments of young branches: the flowers are white, with yellow antheræ; they grow erect, and generally fingle at the top of the branches.

iaricina 3. SPERGULA foliis oppofitis fubulatis ciliatis fafciculatis. Sp.pt. O3i. (Fig. nulla) 1.arch-leav'd Spurrey. Anglis.

Upon diry paftures of a gravelly foil. I obferv'd it upon a hill in the illand of Bute. 4 . VI.

from one root arife feveral ftalks ahout an inch or an inch and a half high: the leaves are linear, fubulate, and acuminated, nightly hairy or ciliated on the edges, and their points turn to one fide of the ftalk: from their ala arife tufts of other leaves, which are the rudiments only of 
young branches : the flowers grow fingly on the fummits of the branches, upon long, naked, flightly hairy peduncles : the fegments of the calyx are oval, obtufe and nightly hairy : the petals are white, and about the length of the calyx: the number of ftamina varies from five to ten, and of ftyles from three to five; but the primary flowers have ten ftamina and five ftyles: the capfule generally nods. It is a matter of fome doubt whether the SAGINA procumbens var. B. Lin. Sp. pl. 185 . (Pet. herb. t. 59. II) be not the fame plant with this. 


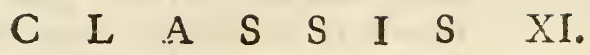

\section{O D E A N D R I A}

\section{$M O N O G Y N I A$.}

LYTHRUM. Cor. 6-petala. Cal. 12-fidus, inferus. Caps. 2-locularis.

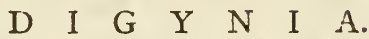

AGRIMONIA. Cor. 5-petala. Cal. 5 -fidus. Sem. I. $\int .2$.

\section{$\begin{array}{lllllllllllllllll} & T & R & I & G & Y & N & I & A .\end{array}$}

RESEDA. Cor. petal. multifidis. Cal. partitus. Caps. I-locularis, hians.

EUPHORBIA. Cor. petal. peltatis. Cal. ventricofus. Caps. 3-cocca.

$$
\begin{gathered}
\text { T E T R A G Y I A. } \\
\text { * Tormentilla erecla. } \\
\text { D O D E C A G Y N I A. }
\end{gathered}
$$

SEMPERVIVUM. Cor. 12-petala, Cal. 12-partitus. Caps. 12. 


\section{MONOG Y N I A.}

LYTHRUM. Gen. pl. 604.

Cal. 1 2-fidus, Petala 6, calyci inferta. Caps. 2 locularis, polyfperma.

falicaria I. LYTHRUM. foliis oppofitis cordato-lanceolatis, floribus fpicatis dodecandris. Sp. pl. 640. (Ger. em. 476.f. 5. Pet. berb. t. 62.f. 6)

Purple-fpiked Willow herb, or Loofeftrife. Anclis. On the banks of ditches and rivers, and in marthy places frequent. 4 . VII.

The ftalk is three or four feet high, erect, quadrangular, and branch'd towards the top into long verticillated fpikes of fpec.ous purple flowers, the leaves grow either oppofite, or three in a whirl: the petals are flaccid: the calyces fefile, and ro-angular.

It is of an aftringent quality, but rarely ufed in medicine. Cattle are fond of it.

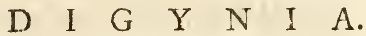

AGRIMONIA. Gen. pl. 607.

Cal. 5-dentatus, altero obvallatus. Petala 5. Sem. 2 , in fundo calycis.

expatoria I. AGRIMONIA foliis caulinis pinnatis, impari petiolato, fructibus hifpidis. Sp. pl. 64j. (Miller. icon. 15. Ger. em. 712)

Agrimony. Anglis. 
On the borders of fields and under hedges. VII. 4

The leaves are pinnated, foft and hairy, confifting of fix or feven pair of ferrated $p: n n c$, with other fmaller ones intermix'd between them, and an odd one at the end : the flowers are yellow, and grow in a long, nender unbranch'd fpike: the fruit, or fwoln calyx, is crown'd with hooked hairs, which adhere readily to the cloaths.

The leaves make a very pleafant tea, faid to be ferviceable in homorrhagies, and in obftructions of the liver and fpleen. The country people alfo ufe them fometimes by way of cataplafm in contufions and frefh wounds.

\section{T $\quad R \quad I \quad G \quad Y \quad N \quad I A$. RESEDA. Gen. pl. 608.}

Cal. I-phyllus, partitus. Petala laciniata. Caps. ore dehifcens, I-locularis.

iuteola I. RESEDA foliis lanceolatis integris bafi utrinque unidentatis, calycibus quadrifidis. Syft. nat. 329 . sp.pl. 643. (Ger. cm. 494)

Wild-woad, Yellow-weed, or Dyers-weed. Anglis. In wafte places near villages, as about Dy art, BurntIfland, and Lafwade, \&c. ๑. VII.

The young leaves are ofter undulated : the talk is a yard high, or more, terminated with a long naked fpike of yellowin green flowers : the calyx is quadrifid, the two upper fegments being widett: the petals are three, the upper one nectariferous 


\section{DODECANDRIA TRIGYNIA.}

and divided half way into fix fegments; the lateral ones trifid: the capfule triangt!lar, unilocular, divided into fix fegments at the top, three ereet anci three inflex'd, and gaping open.

This plant is cultivated and much ufed for dying woollen and filk of a yellow color. The fre?h herb, fhredded and boil'd, or dry'd and reduc'd to a powder, are the ways of ufing it.

lutea 2. R. foliis omnibus trifidis, inferioribus pinnatis. $S_{p}$. p!. 546. (Ger. em. 27\%.f. I. Pet. berb. t. 3\%. f. II.)

Bafe Rocket. Anglis.

In the links of Kirkaldy. Dr. Parfons. ๑. VII.

The Pinnul.e of the leaves are generally undulated, the ftalks reclining, the calyx is divided into fix unequal fegments : the petals are fix, the ftamina about twenty : the capfule thap'd like a triangular prifm.

\section{EUPHORBIA. Gen.pl. 609 .}

Cor. 4 s. 5-petala, calyci infidens. Cal. I-phyllus, ventricolus. Caps. 3-cocca.

* Umbella trifida.

Depius 1.

EUPHORBIA umbella trifida, dichotoma, involucellis ovatis, foliis integerrimis obovatis petiolatis. Sp. pl. 653. (Ger. cm. 503. f. 19. Moris. bift.f. 10.t. 2.f. I1.)

Petty Spurge. Anglis. 
In wafte places about towns and villages, and in gardens frequent. $\odot$. VIII.

The petals are lunular, or Tharply horn'd.

exigua 2. E. umbella trifida, dichotoma, involucellis lanceo. latis, foliis linearibus. Sp.pl. 654. (Ger.em. 503 . f. 17. Pet. berb.t. 53.f. 9)

Narrow-leav'd Dwart-Spurge. Anglis.

In corn tields, and in fandy or gravelly foils, as about Burntifland, \&c. ๑. VIII.

The petals are horn'd.

\section{** Unbelle quinquefida.}

beliofcopia E. umbella quinquefida, trifida, dichotoma, invo3. lucellis obovatis, foliis cuneiformibus ferratis. sp. pl. 658. (Ger. em. 498. f. 2. Moris. bift. S. 10.t. 2.f. g.)

Sun-Spurge, or Wart-Spurge. Anglis. In corn fields and gardens frequent. $\odot$. VIII. 'The petals are roundifh.

The ftamina in this genus do not all appear at the fame time, but break out fucceflively; fo that it would be dificult for a learner in the fcience to determine the genus by the rules of the fexual fyftem; but the germen of a rounded triangular form, terminated with three bifid ftyles, and fupported by a peduncle, will afford him an excel. lent characteriftic mark of this genus; to which may be added, that the feveral fpecies are full of a milky juice, which in mont is of a hot cauftic 


\section{DODECANDRIA DODECAGYNIA.}

nature, capable of raifing a blifter, or burning away warts.

\section{DODE C A G Y I A. SEMPERVIUUM. Gen. pl. 612.}

Cal. 12-partitus. Petcla 12. Caps. 12, polyfperma. ¿ETorum I. SEMPERVIUM foliis ciliatis, propaginibus patentibus. Sp. pl. 664. (Ger. em. 5rc.f. I. Moris. bift. $.12 . t .7 \cdot f \cdot 4 \mathrm{I})$

Houfeleek. Anglis.

Upon houfes, but probably not indigenous. 24. VII. It is recommended as a cooler by way of cataplafm to burns and hot ulcers; and the juice mixed with honey, and laid on with a pencil, has been found of fervice to cure the Thrufh in children. Boerbave found, that ten ounces of the juice, given internally, was beneficial in dyfenteries, and others have found it very ufeful in gonorrhœas. 


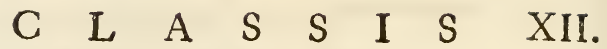

I C O S A N D R I A

M O N O G Y N I A.

PRUNUS. Cal. inferus, 5-fidus. Cor. 5-petala. Drupa nucleo integro.

\section{D $\quad$ I $G \quad Y \quad Y \quad N \quad I \quad A$.}

CRATÆGUS. Cal. fuperus, 5-fidus. Cor. 5.petala. Bacca 2-fperma.

\section{T R I G Y N I $\Lambda$.}

SORBUS. Cal. fuperus, 5-fidus. Cor. 5-petala. Bacca 3-fperma.

\section{P E N T A G Y N I A.}

PYRUS. Cal. fuperus, 5-fidus. Cor. 5-petala. Pomum 5-loculare, polyfpermum.

SPIRÆA. Cal. inferus, 5-fidus. Cor. 5-petala. Caps. plures, congeftr.

$$
\text { P O L Y G Y N I A. }
$$

ROSA. Cal. 5-ídus. Cor. 5-petala. Cal. baccatus, polyfpermus.

RUBUS. Cal. 5-fidus. Cor. 5-petala. Bacca compolita. 


\section{ICOSANDRIA MONOGYNIA.}

TORMENTILLA. Cal. 8-fidus. Cor. 4-petala. Sem, 8, mutica.

DRYAS. Cal. 8-fidus. Cor. 8-petala. Sem. plurima, arifta lanata.

FRAGARIA. Cal. ro-fidus. Cor. 5-petala. Sem. plurima fupra receptaculum baccatum, decidua. POTENTILLA. Cal. io-fidus. Cor. 5-petala. Sem. plurima, mutica.

GEUM. Cal. so-fidus. Cor. 5-petala. Senz. plurima, arifta geniculata.

COMARUM. Cal. io-fidus. Cor. 5-petala. Serr. plurima fupra receptaculum carnofum perfiltens.

* Spirca Filipendula, Ulinaria.

$$
\begin{aligned}
& \text { M C N O G Y N I A. } \\
& \text { PRUNUS. Gen. pl. } 620 .
\end{aligned}
$$

Cal. 5-fictus, inferus. Petala 5. Drupe nux futuris prominulis.

ndus. I. PRUNUS floribus racemofis, foliis deciduis bafi fubtus biglandulofis. Sp. pl. 677. (Oed. Dars. $t$. 205.0 t. Ger. em. 1504.f.9)

Bird-Cherry, Anglis. Hag-berries. Scotis.

In woods frequent, as about Meivil-Caftle, and at Carubber-Den, and in the woods about PentonBridge and Broombolm, in Efidale, \&c. h. V.VI, The flowers grow in cluter'd fpikes, and make an elegant 


\section{ICOSANDRIA MONOGYNIA.}

elegant appearance : the fruit is black when ripe, and of the fize of grapes, of a naureous talte, eaten in Sreden and Comt/cbatca, but drank by way of infurion in brandy in Scotlond.

avium* 2 . P. umbellis foflilibus, foliis ovato-lanceolatis fubtus pubefcentibus conduplicatis. Syft. nat. 342. sp. pl. 680. (Blackwell, t. 425)

Common wild Cherry-tree. Anglis.

In the woods oppofite to Melvil-Caftle, \&c. but probably fown by birds, and not indigenous. Dr. Porfons. h. V.

It grows to a large tree.

The gems which terminate the branches produce leaves only, generally five in number: the lateral gems produce fefile umbels of flowers, commoniy /three fruit is black," and fometimes red, fmail, but. fweet and agreeable to the tafte, by fermentation making a grateful wine, and by difillation, bruifed together with the ftones, a ftrong fpirit.

infrtitio * 3 PRUNUS pedunculis geminis, foliis ovatis fubvillofis convolutis, ramis fpinefcentibus. $S p \cdot p l .680$. (Figuram non inzenio)

Bullace Tree, or Bullace Plumb. Anglis.

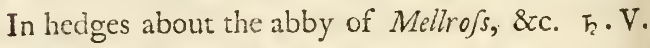

It varies with both white and black fruit.

Spinofa 4. P. pedunculis folitariis, foliis lanceolatis glabris: ramis fpinofis. $S_{p} \cdot p l .68 \mathrm{1}$. Ger. em. I497. f. 5.' 
The Black-thorn, or Sloe-tree. Anglis.

The Slae. Scotis.

An droighionn, preas-nan-airneag. Gauits.

In hedges frequent. h. IV. V.

The bark of this $\mathrm{hrub}$ has been ufed by empirics to cure the ague. It will dye woollen of a red color. The juice of it, with vitriol or copperas, will make good ink; and the fruit will make a very grateful and fragrant wine.

\section{$\begin{array}{lllllll}D & I & G & Y & N & I & A\end{array}$}

CRAT $F G U S . G e n . p l .622$.

Cal. 5-fidus. Petala 5. Bacca infera 2-fperma.

eria. $\beta$. I. CRATEGUS foliis ovatis incifis ferratis fubtus tomentofis. Syft. nat. 342. Sp.pl. 681. (Oed. Dan. t. 302. opt.)

The White Beam-Tree. Anglis.

In woods but not common. h. VI.

I have inferted this on the authority of Sibbeld, not having found it myfelf.

The leaves are oval aind firm, of the fize of the hazel, ftriated with prominent nerves, ferrated on the edges, and hoary underneath: the flowers grow in white umbels : the berries when ripe are red, and capable, by fermentation and difillation, of affording a good fpirit.

s.nyanthe CRATEGUS foliis obtufis fubtrifidis ferratis. Sp. 2.

pl. 683. (Ger. eir. I326.f. I. Blakwell t. 149.) 
The Hawthorn, or White-Thorn, or Quick. Anglis. An fgitheach. Gaulis.

In woods and hedges. $h$. VI:

The number of fiyles, and feeds in the berries are variable. In Camt fchatca the inhabitants both eat the berries and make a wine of them : the highlanders alfo eat them when thoroughly ripe: fwine, deer, and birds are fond of them, particulariy the thrufh kind. The neateft and beft hedges are well known to be made of the young plants of this fhrub. A decoction of the bark with copperas is ufed by the highlanders to dye black.

\section{$T \quad R \quad I \quad G \quad Y \quad N \quad I \quad A$.}

SORBUS. Gen. pl. 623 .

Cal. 5-fidus. Petala 5. Bacca infera, 3-fperma.

eucuparia I SORBUS foliis pinnatis utrinque glabris. $S p$. pl. 683. (Ger.em: 1473)

The Quicken-Tree or Mountain Afh. Anglis. The Roan-Tree. Scotis. Craobh-chaorain. Gaulis. In woods, \&c. frequent, in the lowlands and highlands. 5 . VT.

The leaves are pinnated with about eight pair of Pinnule, of an oval acute form, and ferrated on the edges: the flowers grow in white umbels, upon branched peduncles : the berries when ripe are red, giving the tree an elegant glow in the autumn, 
autumn, and rendering it a great ornament to Thrubberies and other plantations.

They have an altringent quality, but in no hurtful degree: in the inland of Fura they ufe the juice of them as an acid for punch: birds of the thrufh kind are very fond of them, and the highlanders often eat them when thoroughly ripe, and in fome places diftil a very good fpirit from them. The fame ufe is made of them in Camscbatca, as we are inform'd by Ginelin. The wood is hard and durable, fit for many œconomical purpofes, fuch as mill-work, fcrews for preffes, fpokes for wheels, \&c.

It is probable that this tree was in high efteem with the Druids, for it may to this day be obferved to grow more frequently than any other in the neighborkhood of thofe Druidical circles of ftones, fo often feen in Nortb-Britain; and the fuperftitious ftill continue to retain a great veneration for it, which was undoubtedly handed down to them from early antiquity. They believe that any fmail part of this tree carried about them, will prove a fovereign charm againft all the dire effects of enchantment or witchcraft. Their cattle alfo, as well as themfelves, are fuppofed to be preferved by it from evil; for the dairy-maid will not forget to drive them to the ßealings or fummer paftures with a rod of the Roan-tree, which fhe carefully lays up over the door of the fheal bocthy, or fummer-houfe, and drives them home again 
with the fame. In Stratbspey they make, for the fame purpofe, on the firft day of May, a hoop of the wood of this tree, and in the evening and morning caufe all the theep and lambs to pars through it.

\section{P E N T A G Y N I A.}

Cal. 5-fidus. Petala 5 Pomum inferum, 5-loculare, polytpermum.

malus* I. PYRUS foliis ferratis, umbellis feffilibus. Sp. $p l$. 686. (Ger. em. 1461. Blakwell. ta 1-78)

The Crab-Tree or Wilding, when improv'd, the Apple-Tree. Anglis.

Abhal-fiadhaich. Gaulis.

In the woods by Lord Haddington's, \&c. Dr. Parfons. h. V.

This tree in its wild ftate is arm'd with prickles, and the fruit is extremely four, and frequently bitter. Its juice, or crab-vinegar, applied outwardly, is good to cure fpafms, cramps, ftrains, \&c.

The bark will dye woollen of a citron color.

It is remarkable for its longevity : it is faid that fome trees in Hereford/Bire have lived a thoufand years. It flowers with the piony and narcifus poeticus, and makes at that time a moft elegant appearance.

The fruit, mixed with other cultivated apples, or even 


\section{ICOSANDRIA PENTAGYNIA.}

even alone, if thoroughly ripe, will make a found marculine cyder.

\section{SPIREA. Gen. j). 630.}

Cal. 5-fidus. Petala 5. Caps. polyfperma.

filipendula I SPIR ÆA foliis pinnatis; foliolis uniformibus ferratis, caule herbaceo, floribus cymofis. $S p . p l$. 702. (Ger. em. 1058. f. 1. Moris. bift. S. g. t. 20. f. prima. Pet. berb. t. 71.f. 6 \& 7)

Dropwort. Anglis.

In mountainous paftures, as upon the hills to the fouth-weft of Artbur's-Seat, 8rc. 4. VII.

The root confifts of many tubercles, fufpended $b_{y}$, and terminated with thread-like fibres.

The ftalk is about a foot and a half high, crect, and with but few leaves upon it, terminated with a loofe umbel of white flowers, often ting'd with red: the leaves have numerous, oblong, acutely ferrated pinnæ, with fmaller ones intermix'd, and the extreme one divided into three lobes: the petals in this fpecies are generally fix, and the fegments of the calyx are reflex'd: the ftamina are 30 , or more: the germina 12 , or upwards.

Swine are fond of the roots; and Linneus informs us, that in a fcarcity of corn they have been eaten by men infead of bread.

Inaria 2. S. fuliis pinnatis, impari majore lobato, floribus cymolis. Sp.pl. 702. (Ger. em. 1043. f. r. Moris. bift. $\int .9 \cdot t .20 . f .1$. Juperioris ordinis ad dexiram. Pet. berb. t. 71.f. B) 
Meadow-Sweet. Anglis.

Lus-chneas-Chuchullainn. Gaulis.

In wet meadows, and on the banks of ditches and rivers. 4 . VII.

The leaves of this fpecies have only two or three pair of pinnæ, with a few fmaller ones internix'd, the extreme one being larger than the reft and divided into three lobes : the calyx is reddifh, the petals white, the number of capfules from fix to ten, twifted in a fpiral.

The whole plant is extremely fragrant: the common people in Sweden on holidays ftrew their floors with it.

A diftill'd water from the flowers has great efficacy in expelling the meafles and fmall-pox. The whole plant has an aftringent quality, and as fuch has been found ufeful in dyfenteries, ruptures, and in tanning of leather. Horfes and cows do not affect it, but goats are very fond of it.

\section{P O L Y G Y N I A.}

ROSA. Gen. pl. 63r.

Pctala 5. Cal. urceolatus, 5-fidus, carnofus, collo coaretatus. Sem. plurima trifpida, calycis interiori lateri affixa.

\section{* Germinibus fubglobofis.}

spinofifina ROSA germinibus globofis orglabris, pedunculis hifI. pidis, caule petiolifq. aculeatiffimis. $S p . p l .705$. (Ger. em. 1270. f. 4. Clus. bift. 1. p. 116) 


\section{ICOSANDRIA POLYGYNIA.}

Burnet-Rofe. Anglis.

In dry mountainous paftures, as on the fides of the hills by Dudifton Loch, \&c. h. VI.

The ftalk is crouded with ftrait unequal prickles: the leaves are pinnated with nine fmall roundith Foliola: the flowers are cream-color'd, and the fruit black when ripe: the footitalks of the leaves and flowers often vary without prickles.

The variegated rofe mentioned by Sibbald, as growing upon a hill at his Cipbion farm, is only a variety of this. vid. Scot. illuft. $t .2$.

arvenfis 2. ROSA germinibus globofis pedunculifq. glabris, caule petiolifque aculeatis, floribus cymofis. Lin. mantifs. p. 245. Hudf. Angl. p. 192. (Oed. Dan. t. 398. ut. a Linnao citata.)

White-Plower'd Dogs-Rofe. Anglis.

In hedges. Dr. Parfons, h. VII.

This is arm'd with but few prickles, and the leaves are larger than the preceding, and not fo round : the flowers are white, and grow feveral together, fo as to form a kind of umbel.

villofa 3. ROSA germinibus globolss pedunculifque hifpidis, caule aculeis fparfis, petiolis aculeatis, foliis tomentofis. Sp.pl. 704. (Park. par. 418)

The Apple-Rore. Anglis.

About Kiliin, in Breadalbane, and upon the conft of Fife, \&c. 万. VIl.

The leaves are pinnated generally with five hoary S 3 obtule 
obtufe Foliola: the peduncles and germina are covered with fmall prickles: the petals red, the fruit large, fphærical, black when ripe, and fcattered over with ftiff hairs, innocent prickles.

$$
\text { * Germinibus ovatis. }
$$

canina 4. R. germinibus ovatis pedunculiq. glabris, caule petiolifq. aculeatis. Sp. pl. 704. (Ger. em. 1270,f. 3. Blakwell, t. 8)

Briar-Rofe, red-flower'd Dogs-Rofe, or Hep-Tree. Anglis.

An fhearr-dhris. Goulis.

In hedges and paftures. 5 . VI.

The ftalks are thinly arm'd with Tharp crooked fpines : the leaves are pinnated with feven and fometimes nine fmooth foliola, oval, a little acute, and glaucous underneath: the peduncles and germina are fmooth: the petals flefh-color'd, fweet-fcented and emaginated: the fruit oval or urn-Phap'd, finooth and red when ripe.

The pulp of the fruit feparated from the feeds, and mixed with wine and fugar, makes a jelly much efteem'd in fome countries, The bark with copperas dỵes black.

fuarifolia * ROSA germinibus ovatis, caule pedunculifq. acu5. leatis, foliis fubtus glandulofo-pilofis. (Ger. em. 1272. f. 1. ad finiftrain)

The Sweet-biiar. Anglis.

In the hedges about Red-Hall. Dr. Parfons. h. VI. The ftalk is armed with many crooked fpines: the leaves are pinnated generally with five, but fometimes 


\section{ICOSANDRIA POLYGYNIA.}

times feven foliola, nearly round, fmooth on the upper fide, but ciliated on the edges, and cover'd underneath with numerous fhort capillary glands, having fmall red fphærical vifcid heads, which are the caufe of an agreeable fcent in the leaves, refembling that of a ripe apple: the ftipulæ are ciliated, and the footftalks of the leaves cover'd with the fame kind of glands : the peduncles are of a reddih color, covered with ftrait prickles, intermixed with glands: the calyx has the like glands : the flower is fmall and flefh-color'd: the fruit oval, black when ripe, either fmooth or nightly prickled.

The Rofa Eglanteria, of Linnaus, produces a yellow flower, and in other refpects differs from the plant we have now defcribed; and as no fpecies defcribed by that author feems to agree with ours, it was thought more advifeable to give it a new name, than to confound it with other fpecies.

\section{RUBUS. Gen. pl. 632 .}

Cal. 5-fidus. Petala 5. Bacca compofita acinis monofpermis.

* Frutefcentes.

laus 1.

RUBUS foliis quinato-pinnatis ternatifque, caule aculeato, petiolis canaliculatis. $s p . p l$. jo6. (Ger. em. 1272.f. 2. Blakwell. t. 29g)

The Rafpberry-burh. Anglis.

Preas-fubh-craoibh. Gaulis. 
In ftoney mountainous places, as under SalifuryCraigs, and in the inland of Lamlash, on the foutheaft fide of Arran, \&c. h. VI.

The ftalks are nearly erect, and arm'd with fmall ftrait prickles: the leaves are ferrated and hoary underneath: the peduncles rough and hairy.

In the ine of Skye the juice or a fyrup of the fruit is frequently ufed as an agreeable acid for making of punch, inftead of oranges or lemons. A diftill'd water from the fruit is cooling, and very beneficial in fevers.

Eะfius 2. R. foliis ternatis fubnudis; lateralibus bilobis, caule aculeato tereti. Sp.pl. 706. (7. Baupp. II. p. 59) 'The Dewberry-bufh. Anglis.

Under hedges, and in wafte places in the lowlands, but not very common. $h$. VII.

The ftalks generally lie proftrate on the ground: the leaves are ferrated, and downy underneath, but not hoary : the fruit is blue when ripe, compofed but of few Acini, and tafting like a mulberry.

frufticosus RUBUS foliis quinato-digitatis ternatifque, caule petiolifque aculeatis. Sp. pl. 707. (Ger. em. 1272. f. I. Blakwell. t. 45)

The common Bramble. Anglis.

In woods and hedges. $々$. VII.

The ftalks are remarkably long, weak, a little angular, and furnithed with itrong crooked prickles: the lower leaves grow five together, upon one common 


\section{ICOSANDRIA POLYGYNIA.}

common rib; the upper ones only three, having a fine white foft down on their under fide, and unequally ferrated on their edges : the middle leaf is largett, heart-fhap'd, and ftands on a footftalk; the others are feffile: the flowers grow in a loofe clufter, two or three upon a peduncle. The fruit when ripe is black and gloffy.

The leaves are aftringent and drying; a cataplafm made of them has been found ferviceable in the eryfipelas. The juice of the berries, fermented, will make a tolerably good wine.

\section{* Herbacei.}

jaxatilis 4. R. foliis ternatis nudis, flagellis reptantibus herbaceis. Sp.pl. jo8. (Oed. Dan. t. 1 34 opt.Ger. em. $1273 . f \cdot 4)$

Stone Bramble, Anglis. Roebuck-Berries. Scotis.

Caora-bada miann, Ruiteaga. Gaulis.

In ftoney or rough mountainous places not unfrequent, as at Dunkeld and Bloir, and about LochRannoch, in Perthjire, \&c. 万. VII.

The ftalk lies proftrate: the young fhoots are very long, trailing, hairy, and furnifhed with innocent prickles: the leaves are fmooth, the berries red when ripe, and confift of a few large diftinet acini, not cohering together : they are very acid alone, but eaten with fugar they make an agree. able defert, and are efteem'd antifcorbutic. 
The Rufians ferment them with honey, and extract a potent fpirit from them.

chamomo-

rus 5 .

RUBUS foliis fimplicibus lobatis, caule inermi unifloro. sp. pl. 708. (Oed. Dan. t. 1. Flor. Lappon. t. $5 \cdot f$. 1. E' fig. noft.)

Cloud-berries, Knot-berries, or Knout-berries. Anglis. Lus-nan eighreag. Gaulis.

Upon the highland mountains in wet moorifh places not uncommon, as upon Ben-Lomond, about two thirds of the way to the top, upon the mountains about Loch-Rannoch, in Perthoire, and numberlefs other places $h$. VI.

This plant is diccious above ground, but, according to a curious obfervation made by Dr. Solan$d e r$, the roots of the male and female unite together under the earth, fo as to render the plant truly monacious.

The ftalk is erect, about fix or eight inches high, unbranch'd, and bearing generally but two leaves, though fomt times three, growing alternate upon foottalks: each leaf is divided a little way down into five obtufe lobes, unequally ferrated on the edges, and plaited at the nerves, having a pair of oval Stipule at the bafe of the footfalk: a fingle white flower terminates the ftalk, confifting of five, and frequently only four bluntly oval petals. The berry is the fize of a mulberry, when ripe of an orange color, confinting of ten or twelve large acini, of a waterifh or fubacid tafte.

The 
The Swedes and Norwegians efteem the berries to be an excellent antifcorbutic: they preferve great quantities of them in the autumn to make tarts, and other confections. The Laplanders bruife and eat them as a delicious food in the milk of the rein deer; and to preferve them through the winter, they bury them in fnow, and at the return of fpring find them as frem and good as when firft gathered.

In the highlands of Scotland we faw them produced at table as a defert.

\section{FRAGARIA. Gen. pl. 633 .}

Cal. Io-fidus. Pétala 5. Receptaculum feminum ovatum, baccatum, deciduum.

vesca I.

FRAGARIA flagellis reptantibus. Syft. nat. 349 . Sp. pl. 708. (Ger. em. 997.f. I ED 2. Moris. bift. f. 2. t. I9. $f$. I. in medio ordinis superioris. Pet. berb. t. 40. $f .7)$

The Wood Strawberry. Anzlis.

Subh-làir, Subh-thalmhainn. Gaulis.

In woods frequent. 4 . V. VII.

The root and leaves are aftringent and vulnerary: the fruit will diffolve the tartar of the teeth, without acrimony : they have alfo a diuret:c quality, and are found ferviceable in the ftone and gravel. Hoffmon recommends them in fevers and confumptions, and Linnous fays, that by eating plentifully of them every day, he kept himfelf almot free from the gout. A difill'd water, or 
wine, as well as the fruit itfelf, may be ufed in cafes of the ftone, and a fyrup in fevers.

Aterilis 2. FRAGARIA caule decumbente, ramis floriferis laxis. Syft. nat. 350. sp. pl. 709. (Vaill. paris. t. 10.f. 1. bona. Ger. em. 998.f. 3. Pet. berb.t. 40. f. 8. Moris. bift. .. 2.t. 19.f. 5)

Barren Strawberry. Anglis.

In woods and on dry banks, as at Meavis-Bank, \&c. Dr. Parjons. 24. IV. V.

It has no trailing filiform runners like the preceding, and the fruit is dry and pulplefs : the leaves are bluntly oval, ferrated, downy, and of a filky. white underneath; their footfalks remarkably hairy : the flower-ftalks are downy, weak, and filiform: the petals whiter than the preceding, and more deeply emarginated.

\section{POTENTILLA. Gen. pl. 6.34.}

Cal. ro-fidus. Petala 5. Sem. fubrotunda, nuda, receptaculo parvo exfucco affixa.

\section{* Foliis pinnatis.}

anferina I. POTENTILLA foliis pinnatis ferratis, caule repente, pedunculis unifloris. Syft. nat.p. 350. Sp. pl. 7 10. (Ger. em. 993. Moris. bift. S. 2. t. 20.f. 4. ordinis Secundi. Pet. berb. t. 4I.f. I1. Blakwell. t. 6.)

Silver-weed, or Wild-Tanfey. Anglis.

Moor-Grafs. Scotis.

Bar-a'bhrifgein. Gaulis. 
By way-fides, and in low grounds, and places where water has ftood in the winter, and in fandy foil very common. 4. VII.

The leaves confift of ten or twelve pair of ovallanceolate, and acutely-ferrated pinne, growing larger by degrees towards the end of the leaf, and having fmaller ones intermixed between them: the pinne are hairy, and white underneath, fhining like fatin: the flowers are yellow.

It has an aftringent quality, but is rarely ufed in medicine.

The roots tafte like parfneps, and are frequently eaten by the common people in Scotland, either roaft or boiled.

In the iflands of Tirey and Col they are much efteemed, as anfwering in fome meafure the purpofes of bread, they having been known to fupport the inhabitants for months together, during a fcarcity of other provifions. They put a yoke on their ploughs, and often tear up their pafture grounds, with a view to eradicate the roots for their ufe; and as they abound moft in barren and impoverifh'd foils, and in feafons that fucceed the wort for other crops, fo they never fail to afford a moft feafonable relief to the inhabitants in times of the greateft fcarcity. A fingular inftance this of the bounty of providence to thefe inands!

Cattle reject the leaves of this plant, but fwine are fond of the roots.

$$
\text { ** Foliis digitatis. }
$$

POTENTILLA 
from one point, which are ferrated on the upper part generally with five but fomet mes feven parabolic dents, of which the central or extreme one is the fhorteft : below the middle thefe Filiole have their edges entire, and are a lirtle hairy on both fides, but more fo on their edges. Ai the bafe of the footfalks of the radical leaves are two entire, lanceolate, hairy stipule. Upoin the flower-ftalks are wide, oval, lanceolate Bractee, which frequently coalefec at their bafe, and fupport between them a feffile leaf, divided into three lobes, the central of which is of ten trind: thefe Braciea are placed under the ramifications of the ftalk; for on the peduncles they are oppofite, fimple, and undivided. The Calyces are hairy, the expanded Corolla a little more than half an inch in dianteter, the Petals either uniformly yellow, or fometimes orange-color'd at the bafe.

The P. opaca \& curea differ fo little from the P. verna, that Halier feems to think the firft ought not to be diftinguifhed from it, (Hift. Stirp. Helvet. n. I 120) and Scopoli affirms the fecond to be only a variety of it. (Flor. Carniol n.621.) They differ only quoad majus \& minus, but the general habit, foil, figure of the petals, roots and leaves, agree in all.

4. POTENTILLA foliis quinatis, caule repente, pedunculis unifloris. Sp.pl. 714 . (Ger. em. $987 \cdot f$. 
I. Moris. bift. f. 2. t. 19. f. 7. Pet. berb. t. 4I. f.3.)

Common Cinquefoil, or five-leav'd Grafs. Anglis. In damp clayey foils, but not very frequent. $2 \%$. VII.

The root and leaves are aftringent and vulnerary. A decoction of them has been found ferviceable in dyfenteries and agues.

\section{TORMENTILLA. Gen. pl. 635 .}

Cal. 8-fidus. Petala 4. Sem. fubrotunda, réceptaculo parvo exfucco affixa.

erecta 1. TORMENTILLA caule erectiufculo, foliis feffilibus. Sp. pl. 716. (Ger. em. 992. Moris. bift. S. 2.t. 19. f. 13. Blakwell. t. 445.)

Tormentil or Septfoil. Anglis.

Bàr-braonan-nan-con. Gaulis.

In barren paftures, moors and heaths almoft every where. 24. VII.

The roots confint of thick tubercles, an inch or more in diameter, replete with a red juice, of an aftringent quality. They are ufed in moft of the weftern ines, and in the Orknies, for tanning of leather; in which intention they are proved, by fome late experiments, to be fuperior even to the oak-bark. They are firft of all boiled ir water, and the leather afterwards fteeped in the cold liquor. In the inands of Tirey and Col the inhabitants have deftroyed fo much ground bj digging 


\section{ICOSANDRIA POLYGYNIA.}

digging them up, that they have lately been prohibited the ufe of them.

A decoction of thefe roots in milk is alfo frequently adminiftred by the inhabitants of the fame inands in diarrhæas and dyfenteries, with good fuccefs; but perhaps it would be moft proper not to give it in dyfenteries till the morbid matter be firft evacuated. A fpirituous extract of the plant ftands recommended in the fea-fcurvy, for to ftrengthen the gums and faften the teeth. Linsaus informs us, that the Laplanders paint their leather of a red color with the juice of the roots.

reptans 2. TORMENTILLA caule repente, foliis petiolatis. sp. pl. 716. (Pet. berb. t. 41.f. 10. Plot. nat. ox. C. 6. $.7 \cdot 7 \cdot t \cdot 9 \cdot f \cdot 5$.

Creeping Tormentil. Anglis.

In barren grounds, but not common. Sibbald. 2 . VIII.

It greatly refembles the POTENTILLA reptans, for the flowers have frequently five petals.

\section{GEUM. Gen. pl. $6{ }_{3} 6$.}

Cal. 10-fidus. Petala 5. Sem. arifta geniculata.

urbanum 1. GEUM floribus erectis, fruetibus globofis villofis; ariftis uncinatis nudis, follis lyratis. Sp.pl. 716. (Ger. em. 994.f. 1. Pet. berb. t. 40. f. 1. Blakwell. t. 253)

Common Avens, or Herb-Bennet. Anglis. 
In woods and hedges frequent. 4 . VI.

The root is thick, hrown, woody, and of a conical figure, fmelling fometimes in the fpring like cloves: the leaves are hairy and pinnated, the two or three lowent pairs being very fmall, and the extreme one very large, and divided into three lobes: the ftipulz are large, and deeply indented: the flowers are fmall and yellow : the beards of the feeds hooked.

The root is aftringent: an infufion of it in wine, or thirty or forty grains of the powder, is eiteem'd a good miedicine at the end of a dyfentery.

rivale 2.

G. floribus nutantibus, fructu oblongo; ariftis plumofis tortis. Sp.pl. 717 . Syft.nat. 352. (Ger.em. 995. f. 4. Pet. berb. t. $40 \mathrm{f} \cdot 3$ )

Red Water Avens. Anglis.

In wet and moorifh grounds very oommon. 4. VII. The flowers of this are pendulous : the calyces cylindrical, and of a dull red color: the petals erect, emarginated, red and vein'd.

It is found beneficial in diarrhæas and hæmorrhagies, and in Canada we are told it is ufed inftead of bark for agues.

DRYAS. Gen. pl. 637 .

Cal. 8-fidus. Petala 8. Sem. caudata, pilofa. oEropetala I DRYAS octopetala, foliis fimplicibus. Syft. not. 352. Sp. pl. 717. (Oed. Dan.t. 31. Ger. em. 659. f. 6. EJ voy. Hebrides, xxxiii.) 
The Dryas, or Mountain Avens. Anglis.

Upon the highland mountains in many places, as upon talky foils on the eaftern fides of Maolgblas, Mal-grea, and Creg-cbaillech, in Breadalbane, and plentifully upon the limeftone rocks of Ben-buardal, \&c. in the parilh of Cbrift-Cburch, in Stratb-Swardle, in the inle of Skye; and ftill more abundantly for two miles together upon a vatt limeftone rock called Creg-acbnocaen, upon the boundaries of Coygacb $E^{3}$ AJjynt, juft on the confines of Ro/sfbire and Sutberland, about ten miles from Locb-Broom, in the road to Lead-beg, upon the weftern coaft. It has likewife been found by my often-mentioned friend, Mr. Stuart, upon the top of Carn-dearg, one of the lower heads of Ben-fguilert, a high mountain in GlenCreran; and near the top of Malmore, in Glen-co, both in the diftricts of Upper-Lorn, in ArgyleSire. 4. VI.

The ftalk and branches are woody and perennial, lying flat upon the ground, and fpreading wide about the root in tufts : the leaves are evergreen, oval, ferrated, hard and ftiff, of a dark green wrinkled furface on the upper fide, and hoary underneath, having woolly footfalks: the peduncles are downy, fcattered with purple hairy glands, and bearing fingle flowers, confifting generally of eight white petals. It has never yet been found in Englaud.

The DRYAS pentapeiala, mentioned by sibbald, $\mathrm{T}_{2}$ 


\section{ICOSANDRIA POLYGYNIA.}

as growing in the den of Betbaick, four miles from Perth, is now not to be found there; poffibly the POTENTILLA argentea was miftaken for it.

\section{COMARUM. Gen. pl. 638 .}

Cal. so-fidus. Petala 5, calyce minora. Receptac. feminum ovatum, fpongiofum, perfiftens.

paluftre 1. COMARUM. sp. pl. 718. (Ger. en. 987. f. 4. Moris. bift. S. 2. t. 19.f. 4. Eง ejus var. Plukenet. t. 212.f. 2. Pet. berb. t. 4I.f. 2)

Purple Marh Cinquefoil. Anglis.

In peat-bogs and marhes frequent. 4. VII.

The falks are proftrate and creeping: the leaves are pinnated with five or feven oval, ferrated $F_{0}$ liola, the odd one at the end being largeft: the flowering ftems are red, and a foot and a half high, bearing feveral flowers towards the top: the Calyces are large, and of a dull purple, or blood color, confifting of ten fegments, alternately great and fmall: the Petals are much fmaller than the Calyx, of the fame color, and ligulate or tongue-fhap'd: the Staminia are of the fame color as the Petals: the Antbera yellow, and the Receptacle of the feeds, when ripe, tumid and flefhy.

The roots will dye wool of a red color, and have aftringency exiough to tan leather. 
P O L $\quad$ Y A $A$ N D R I A.

C L A S S I S XIII.

P O L Y A N D R I A MONOG Y I A.

* Tetrapetali.

PAPAVER Cal. 2-phyllus. Capfula I-locularis, coronata.

CHELIDONIUM. Cal. 2-phyllus. Siliqua.

* Pentapetali.

GISTUS. Caps. fubrotunda. Cal. 5-phylli, foliola 2, minora.

TILIA. Caps. 5 locularis, coriacea, I-fperma. Cal. deciduus.

* Polypetali.

NYMPHÆA. Bacca. multilocularis, corticofa. Cal. magnus.

$$
\begin{gathered}
\text { T R I G Y N I A. } \\
\text { Refeda Luteola. } \\
\text { P E N T A G Y N I A. }
\end{gathered}
$$

AQUILEGIA. Cal. nullus. Cor. 5-petala. Ne.7. vio 5, infernè cornuta.

$$
\text { T } 3 \text { POL.YGYNIA, }
$$




\section{P O L Y G Y N I A.}

THALICTRUM. Cal. nullus. Cor. 4-s. 5-petala. Sem. plurima, fubmutica, nuda.

HELLEBORUS, Cal. nullus. Cor. 5-petala, perfiftens, Nectaria plura. Caps. polyfperma.

CALTHA. Cal. nullus. Cor. 5-petala. Caps. plurimæ. Nectaria nulla.

ANEMONE. Cal. nullus. Cor.6-petala. Sem. plurima.

TRCLLIUS. Cal. nullus. Cor. 14-petala. NeEtaria linearia Capfule monofpermæ.

RANUNCULUS. Cal. 5-phyllus. Cor. 5-petala. Sem. plurima. Petala ungue nectarifero.

\section{MO NOG Y N I A. \\ * Flores tetrapetali. \\ CHELIDONIUM. Gen. pl. 647 .}

Cor. 4-petala. Cal. 2-phyllus. Siliqua I-locularis, linearis.

majus I.

CHELIDONIUM pedunculis umbellatis. $s p$. $p l$. 723. (Miller. ic. 92. f. 1. Blakwell. t. 91. Ger. em. 1069. $f .1$ )

Celandine. Anglis.

In wafte places about towns and villages, but not common. 24. VI,

The whole plant is full of a yellow, bitter, acrid juice, efteemed good in the jaundice and dropfy. It is ufed outwardly to take away warts, tetters, ringworms, 


\section{POLYANDRIA MONOGYNIA.}

ringworms, \&c. and diluted with rofe-water, to take fpecks and films off the eyes.

glaucium 2. C. pedunculis uniforis, foliis amplexicaulibus finuatis, caule glabro. Sp. pl. 724. (Ger. em. 367 . f. 1. Pet. berb. t. 52. f. 7)

Yellow-horned Poppy. Anglis.

Upon the fea coafts near the Queens-Ferry, and at Charles Town, the great lime-works of Lord Elgin, \&c. $\odot$. VII.

The leaves are roughly hairy and glaucous: the flowers yellow, fucceeded by a rough cylindrical curved pod, fix inches long, terminated with a conical Stigma, divided into four lobes: the pod has two cells, divided by a fpongy partition, in which the feeds are imbedded.

\section{PAPAVER. Gen. pl. 648.}

Cor. 4-petala. Cal. 2-phyllus. Caps. I-locularis, fub ftigmate perfiftente poris dehifcens.

\section{* Capjulis bijpidis.}

rgemone I. P. capfulis clavatis hifpidis, caule foliofo multifloro. sp. pl. 725. (Ger. en. 3;3.f. 2. Moris. hifr. f. 3.t. 14.f. 10. Pet. berb.t.52.f. 6)

Long rough-headed Poppy. Anglis.

In corn fields, but not common. Dr. Parfors, $\odot$.

VI.

$$
\text { ** Capjulis glabris. }
$$

bacas 2. P. capfulis glabris globofis, caule piloto multifluro, foliis 
foliis pinnatifidis incifis. Sp. pl. 726. (Ger. em. 371. f. 1. Moris. bift. .. 3. t. 14. f. 6. Pet. berb. t. $52 . f .2$ )

Red Poppy, or Corn Poppy, or round fmoothheaded Poppy. Anglis.

In corn fields. Dr. Parfons and Sibbcld. ○. VII. The leaves are hairy: the hairs on the ftalk are patent or horizontal: the petals of a bright fcarlet color, with black purple ungues, and much larger than in the other fpecies of this genus: the capfules not properly fphærical, but of a hort bluntly-oval figure.

A conferve, infufion, or fyrup of the flowers, is efteemed as a gentle Narcotic and Anodyne.

dubium 3. P. capfulis oblongis glabris, caule multifloro fetis adpreffis, foliis pinnatifidis incifis. Sp. pl. 726 . (Moris. bift. S. 3. t. 14.f. I1. Pet. berb. t. $5^{2}$. $f \cdot 3$ )

long fmooth-headed Poppy. Anglis.

In corn fields, \&c. the moft common kind in NortbBritain. ๑. VII,

\section{* Flores pentapetali.}

TILIA. Gen. pl. 660.

Cor. 5-petala. Cal. 5-partitus. Bacca ficca, globofa, 5-locularis, 5-valvis, bafi dehifcens.

eurcpen 1. "TILIA floribus nectario deftitutis. Sp. pl. 733 . (Ger. emac. 1483.f. I. Bfakwel. t. 469) 
The Lime or Linden-Tree. Anglis.

In walks and avenues, as at Inverary, \&c. but probably not indigenous. $々$. VII.

The leaves are heart-hap'd, with the apex produced, and ferrated on the edges: the nerves on the under fide have hairy or fpongy clufters at their divifions : the peduncles are furnifhed with a remarkable foliaceous Bractea or ligament of an elliptic form: the flowers grow in a thin umbel, from three to nine together, of a whitifh color, and fragrant fmell; very grateful to bees.

The wood is light, fmooth, and of a fporgy texture, uied for making lafts and tables for thoemakers, \&c.

Ropes and bandages are made of the bark, and mats and ruitic garments of the inner rind in Carniola, and fome other countries.

$$
\text { CISTLS. Gcn. pl. } 673 \text {. }
$$

Cor. 5-petala. Cal. 5-phyilus, foliolis duobus minoribus.

beliantbe-

CISTUS fuffruticofus procumbens, fipulis lanceomum $\mathrm{I}$.

latis, foliis oblongis revolutis fubpilofis. sp. pl. 744. (Oed. Dan. t. 1ог opt. Loefel. Flor. Prufs. 43. t. 8. bona. Ger. em. $1282 . f .3$ ?)

Dwarf Ciftus, or little Sun flower. Anglis.

In dry paftures and rocky expofures, but not very common; as upon the tills in the king's park at Edinburgh. 


\section{POLYANDRIA MONOGYNIA.}

Edinburgh, and in the inand of Lijmore !plentifully. $\mathrm{h}$. VII. \& VIII.

The petals are yellow, thin and flaccid, like thofe of the poppy.

\section{*** Flores polypetali.}

\section{NYMPHAEA. Gen. pl. 653.}

Cor. polypetala. Cal. tetra feu pentaphyllus. Bacca multilocularis truncata.

NYMPHAEA foliis cordatis integerrimis, calyce petalis majore pentaphyllo. Sp. pl. 729. (Blakvell. t. 497. 498. 6. 500. Ger. em. 819.f. 2)

Yellow Water-Lilly. Anglis.

In lakes and ditches, but not very common. Sibbald and Dr. Parfons. 4. VIII.

The leaves are fmooth, plane, tough and pliant, ten or twelve inches in diameter, and float upon the furface of the water: the leaves of the Calyx are tough, and yellow within : the Petals are yellow, much fmaller than the Calyx, in number from 14 to 20 , furrow'd and crenated: the Stamina are more numerous, at the firft expanfion of the flower adhering clofely to the fruit, but afterwards are reflexed: the flower blooms out of the water, but the fruit reverts and ripens its feed under it. This fruit is of a pear-fhap'd, or oval-conic figure, crowned with a flat radifated Difc or Stigma, confifting of as many rays as the fruit has cells, like as in the poppy. 


\section{POLYANDRIA MONOGYNIA.}

Linnaus tells us that fwine are fond of the leaves and roots of this plant; and that crickets and Blatta, or cock-roaches may be driven out of houfes by the fmoke in burning of it.

alba-2. N. foliis cordatis integerrmis, calyce quadrifido. Sp. pl. 729. (Blakwell. t. 498, 499, 500. Ger. em. 8 (g.f. 1)

White Water Lilly. Anglis.

An duilleag-bhàit', Rabhagach. Gaulis.

In lakes and ditches very frequent. 2 . VII \& VIII.

The leaves of this are much like the preceding, but rather larger: the Petals are white, from 16 to 20 in number, wider than the leaves of the Calyx, and more oval, the exterior ones approaching to the nature of the Calyx, the interior ones, which are gradually fmaller, to the Stamina: the number of Stamina is 68 or 70 , and the outermoft of thefe do again refemble the inner Petals, fo that the flower in its natural ftate has the appearance of being double. It raifes itfelf out of the water, and expands about feven o'clock in the morning, and clofes again, repofing upon the furface, about four in the evening. The fruit is fphærical, crowned with a radiated difc, lil:e the preceding.

The root has an aftringent and bitter tafte, like the roots of moit aquatic plants that run deep into the mud. The highlanders make a dye with it of a dark chefnut color. 


\section{P E N T A G Y N I A.}

AQUILEGIA. Gen. pl. 684.

Cal. o. Petalo 5. Nectaria 5, corniculata, inter petala. Caps. 5 diftinetæ.

vulgaris 1. AQUILEGIA nectariis incurvis. Sp.pl. 752. (Blakwell t. 499. Ger. em. 1093. f. 1. Moris. bift. S. 12. t. I. $f$. 1. ordinis infinii)

Columbines. Anglis.

In woods not unfrequent, as in Collington woods, \&c. Dr. ?. juis. 4. VI.

\section{P O L Y G Y N I A.}

ANEMONE. Gen. pl. 694 .

Cal. o. Petala 6-9. Semina plurima.

nemorofa I. ANEMONE feminibus acutis, foliolis incifis, caule uniforo. Sp. pl. 762. (Ger. em. $3^{8} 3$. f. 2. Per. berb. t. 40. f. 9. Moris. hift bift. f. 4. t. 28 . f. 10.)

The Wood Anemone. Anglis.

In woods frequent, as at Rofin, \&c. $24 . \mathrm{V}$.

The petals are white, often tinged on the outfide with red, and are generally fix in number. They clofe together in rainy weather, and the flower hangs downwards. Linnous fays, that eating of this herb will caufe cattle to make bloody water, and bring on a dyfentery.

THALIC IRUM. 


\section{THALICTRUM. Gen. pl. 697 .}

Cal.o. Petala 4 in plerifque. Semino nuda ecaudata.

Alavum 1. THALICTRUM caule foliofo fulcato, panicula multiplici erecta. Sp. pl. 7jo. (Ger. em. 125r.f. I. Gefneri icon cen. p. 79)

Meadow Rue. Anglis.

On the banks of rivers, but rare. At NortbQueen's-Ferry, in Fifeßhire. Dr. Parfons. 24. VII. It has commonly 24 Stamina, and Piftils from 10 to 16. It varies, fometimes with leaves divided into much narrower lobes, and more wrinkled, as figured by Morifon among his umbelliferous. plants, tab. 12. Eo bift. . 9. t. 20.f. 3 .

The root and leaves will dye a yellow color. Cattle are fond of this plant.

minus 2.

THALICTRUM foliis fexpartitis, foribus cernuis. Sp. pl. 76g. (Ger. em. 125r.f. 2. Seguier. veron, 476. t. I I. OEder. Dan. t. 244. Sed. minùs ra. mosa. Moris. bift. S. g. t. 20.f. 12)

The leffer Meadow-Rue. Anglis.

In fandy foils and mountainous paitures not uncommon. We obferved great quantities of it about Kil-cbomin in Ile, and at I-columb-kill, in fandy grounds. Mr. Stuart found it in the paftures about Loch-Rannocb, in Pertbjhire, and in many other places. 24. VII.

The italk is ftriated, and about a foot high : the leaves grow lax and divaricated, having rigid footitalks ; 


\section{POLYANDRIA POLYGYNIA.}

footfalks; they are fmooth and glaucous, and their lobes generally trifid : the panicle is branch'd and open, and the flowers nod: the petals are of a pale green, tinged with red: the Stamina are from fifteen to twenty; the feeds deeply ftriated, in number from two to feven.

alpinum 3. T. caule fimplicifimo fubnudo, racemo fimplici terminali. p.pl. 767. (Oed. Dan. t. 11. opt. Moris. bift. . 9. t. 20.f. 14. Pet. berb. t. 71. f. 12. E fig. noft.)

Alpine Meadow-Rue. Anglis.

By the fides of rivulets on the highland mountains frequent, as upon Maol-gblas, in Breadalbane, and the mountains about Loch-Rannoch, in PerthBire; on Baikerall, in the ifland of Rum; on Ben-na-Grion, two miles above $M$ 'Kennon's caftle, in Strath, in the ine of Skye; on Ben-na-Scree, above Arnesdale, by the fide of Locb Urn, on the weftern coaft of Inverne/shire, and numberlefs other places. It has likewife been obferved in the lowlands, as upon Hart-Fell, near Moffatt, in Annandale, by Mr. Sheffeld, Fellow of Worcefter college, in Oxford. 24. VI. VII.

It is an elegant little plant, about a finger's length in height, and truly alpine : the leaves all arife from the root, the ftalk being naked and unbranched : the flowers nod, and have four $P_{\ell-}$ tals, twelve stciaina and eight Pijtills. 



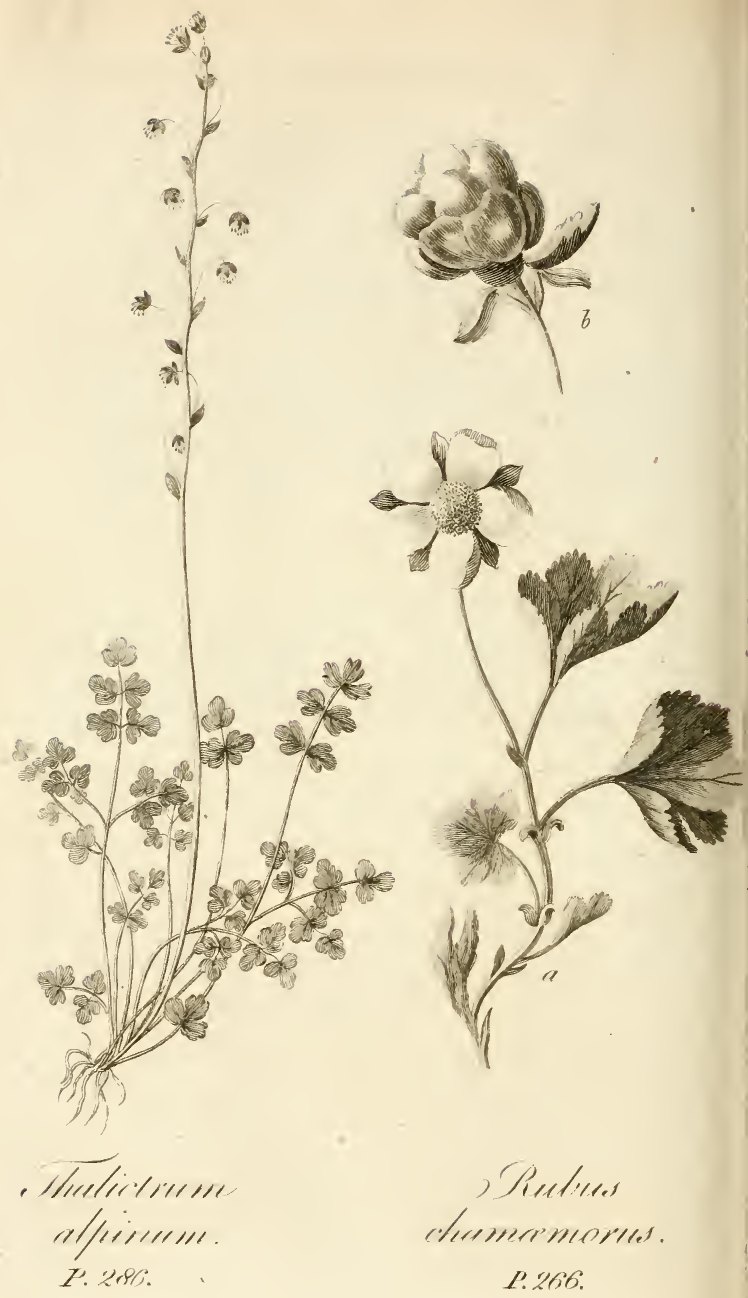




\section{RANUNCULUS. Gen. pl. 699.}

Cal. 5-phyllus. Petala 5 intra ungues poro mellifero. Sem. nuda.

Obs. Character effentialis conffftit in Nectario; relique partes frubtificationis inconftantes, bincNectario incognito, tanta confufio generis.

Nectarium hoc autem in aliis porus nudus, in aliis margine cylindraceo cinctus, in aliis fqumula emarginata claufus.

\section{* Foliis fimplicibus.}

lingua $\mathrm{I}$.

RANUNCULUS foliis lanceolatis, caule erecto. Sp. pl. 773. (Ger. em. g6i. f. I. Moris. bift. S. 4 . t. 29.f. 33. Pet. berb. t. 39.f. 5)

Great Spearwort. Angiis.

By the fides of lakes and in deep muddy ditches, but not common. At the end of Didifton-Loch, near Edinburgh. Dr. Parfons. 4. VII.

The ftalk is two or three feet high, hollow, erect, and branched towards the top: the leaves are nightly denticulated on the edges, hairy and rough to the touch, feffile, and fheathing the ftalk at their bafe : the Calyx is a little hairy : the flower is of a fhining yellow color, an inch or more in diameter: the nectariferous pore at the bafe of the petal has a prominent fcale over it. The whole plant is acrid and cautic. 
fammula 2 RANUNCULUS foliis ovato lanceolatis petiolatis, caule declinato. $S_{\hat{p}}$. 'll. 772. (Ger. emac. 96r. f. 2. Moris. bift.. . 4. t. 29. f. 34 . \& variet. Poliis fubferratis. Ger. em. 962. f. 3. Moris. bift. S. 4.t. 29.f. 35. Pet. berb. t. 39.f. 6)

Leffer Spearwort. Anglis.

An lus-mòr, Ghlais-ieun. Gaulis.

On the fides of iakes and ditches very common. $\boldsymbol{u}$. VII.VIII.

The ftalk is often a cubit high, proftrate at the bafe, but erect upwards and branched: the leaves are elliptical, of a thick and firm texture, generally fmooth, but fometimes a little rough and hairy, moft commonly entire on the edges, but fometimes a little ferrated : they theath the ftalk at their bafe like the preceding : the uppermoft leaves are linear: the Calyx is a little hairy, the flower not above half an inch in diameter, the Petals yellow and Rining, the nectariferous pore encompaffed with a prominent fcale. By this it appears, that in fome ftates it differs very little from the $\mathrm{K}$. Lingua. It varies wonderfully in magnitude, and in gravelly foils, degenerates to fuch a trailing dwarfifh and diminutive fize, with linear leaves, that it is difficult to diftinguin it from the following fpecies.

It has an acrid and cautic quality, and is ufed in many parts of the highlands to raife blifters: for this purpofe the leaves are well bruifed in a 


\section{POLYANDRIA POLYGYNIA.}

mortar, and applied in one or more limpet inells to the part where the blifters are to be raifed. This is the practice in the inle of Skye, and other places upon the coaft.

reptans 3. RANUNCULUS foliis linearibus, caule repente. Sp. pl. 773. (OEder. Dan.t. 108. Flor. Lappon.t. $3 \cdot f \cdot 5 \cdot E^{3}$ fig. noft.)

Narrow-leav'd Creeping Spearwort. Anglis.

By the fides of lakes, but rare. At the welt end of Locb-Leven, in Kinrofsfire. Dr. Parfons. 4. VII. VIII.

The ftalk is long and flender. It creeps upon the ground, and takes root at every joint, but approaches fo near to fome ftates of the preceding fpecies, that Haller, in his Itift. Stirp. Helv. and Scopoli, in his Flor. Carniol. are confident it is no other than a variety of it, and Linneus himfelf fufpects the fame.

crivi 4. R. foliis cordatis, angulatis, petiolatis, caule unifloro. Syft. nat. Linn. p. 378. Sp. pl. 774. (Eder, Dan. 499. opt. Ger. em. 816. Blakwell. t. 51) Pilewort, or leffer Celandine. Anglis.

Under hedges, on fhady banks and in woods, very common. 24. IV, V.

The root confifts of fmall fibres, intermixed with a clufter of tubercles: the Calyx has generally but three deciduous leaves, and the flower commonly eight Petals, each having a nectariferous emargi- 
nated fcale at its bafe. The Stamina are in number from 18 to 36 , the Germina from 16 to 24. The flower opens at nine o'clock in the morning, and rlofes at five in the evening.

The young leaves in the fpring are boiled by the common people in fome parts of Sweden, and eaten as greens. The roots are fometimes wafh'd. bare by the rains, fo that the tubercles appear above ground, and in this tate have induced the ignorant, in fuperftitious times, to fancy that it has rained wheat, which thefe tubercles do a little refemble. The feeds of this plant commonly prove abortive, but this defect in nature is amply compenfated by its remarkable readinefs to encreafe by the granulated roots.

\section{* Foliis difseztis E divifs.}

auticonus 5 RANUNCULUS foliis radicalibus reniformibus crenatis incifis, caulinis digitatis linearibus, caule multifloro. Sp. pl. 775. (Ger. em. 954. f. 7. Pet. berb. t. $3^{3} \cdot f \cdot 2$. E f. 6. Moris. lift. S. 4. t. 28. f. 15)

Sweet Wood Crowfoot, or Goldilocks. Anglis.

In woods and tharly places. Upon the banks of the river oppofite Logton woud, near Dalkith. Dr. Parfons. 4. V.

The leaves are fnooth, the radical ones are fome of them kidney-hap'd and crenated, and others divided into three lobes, all fupported by long footitalks. Thoie on the upper part of the ftalk 


\section{POLYANDRIA MONOGXNIA.}

are feffile, digitated, and entire on the edges: the Calyw ftands open, and is reflexed before it decays: the petals, in the perfect ftate of the plant, are five in number, of a fhining yellow color, but they are often not above two or three, and fometimes none, in the early flowering fpecimens. This kind has no biting or cauftic quality.

celeratus 6 R. foliis inferioribus palmatis, fummis digitatis, fructibus oblongis. Sp. pl. 776 . (Ger. $\mathrm{em} .962 . f$. 4. Blakwell herb. t. 259. Pet. berb. t. 39.f. 11 )

Celery-leav'd Crowfoot. Anglis.

On the fides of ditches and ponds near towns and villages not unfrequent. Dr. Parfons. $\odot$. VI.

The falk is thick and pithy, a cubit high, and branched : the leaves are all fmooth, the radical ones fupported by footfalks, and divided into three lobes, the lateral ones of which are trifid. the ftalk-leaves are palmated, being deeply divided into narrow fegments; the uppermolt ate elliptical.

The flowers are yellow, fhining and fmall, in proportion to the fize of the plant, and the other fpecies of this genus: the calyx is yellow!h, fmooth and reflexed: the nectariferous pore at the bafe of the petal is furrounded with a prominent margin: the Stamixs are in number from I2 to 20 : the receptacle of an oval-conic form. The whole plant has a moft acrimonious quality; if bruifed and laid upon any part of the bock, 
it will in a few hours raife a blifter. Strolling beggars have been known fometimes purpofely to make fores with it, in order the more readily to move compaffion.

bulbofus 7. RANUNCULUS calycibus retroflexis, pedunculis fulcatis, caule erecto, foliis compofitis. $S p . p l$. 779. (Ger. em. 953. f. 6. Pet. berb. t. 38. f. 4.) Bulbous Crowfoot, or Butter-cups. Anglis.

In meaciows and paftures frequent. 4. V.

It has a bulbous root, fhaped like a fmall turnep: the leaves are hairy, and divided to the bafe into three lobes, the middle one of which ftands on a fcotfalk; thefe lobes are again fubdivided half way down into three others, which are fharply indented on their ediges: the petals are of a hining yellow color, having a nectariferous pore at their bafe, of a bluntly triangular form : the Stanine are about 60: the Antbere acuminated. The whole plant is extremely acrid and corrofive, efpeciaily the frefh roots, which will readily raife a blifter, and as fafely as Cantbarides; and yet notwithftanding this corrofive quality, the roots when boiled become fo mild as to be eatable.

repens 8. RANUNCULUS calycibus patulis, pedunculis fulcatis, ftolonibus repentibus, foliis compofitis. I.in. $\int y$ ft. nat. p. 379. Sp. pl. 779. (Ger. em.951. f. 1. Blakwell. t. 31. Pet. berb.t. $3^{8} \cdot f .7$ E 8) Creeping Crowfoot. Anglis. 
Under hedges and in gardens frequent. 24. VI.

There are often the veftiges of a bulb to be feen at the root of this plant, which feems to have been divided into creeping offsets by age, or lome particular foil or expofure. The great $\mathrm{Hal}_{\mathrm{a}}$ $l e r$ is of opinion, that this is no other than a va. riety of the preceding fpecies.

The footitalks of the leaves at the bafe are dilated into a broad, whitifh membrane, which embraces the ftalk: the nectariferous fcale at the bafe of the petals is broad and lightly bifid.

R. calycibus patulis, pedunculis teretibus, foliis tripartito-multifidis; fummis linearibus. Sp. pl. 779. (Ger. em. 951,f.2)

Upright Meadow Crowfoot. Anglis.

In meadows and paftures very common. 24. VIl.

The ftalk is erect, cylindrical, two feet high, fiftular, and very much branched: the leaves are rough, divided to the bafe into three primary lobes, the middle one of which is trifid; and the lateral ones fubdivided into two lobes, each of which is bifid: the Calyx is fmooth, the Petals vellow and gloffy, the nectariferous fcale at their bafe nearly heart-fhap'd: the Stomina from 48 to $5^{6}$; the Germina about $5^{6}$.

The whole plant is hot and cauftic, readily and fafely raifing a blifter, without affecting the urinary paffages, by bringing upon the patient a flrangury or the like. 
'The cattle leave this plant untouch'd, at lealt the ftalks and flowers of it.

arvenfis 10. RANUNCULUS feminibus aculeatis, foliis fuperioribus decompofitis linearibus. $S p . p l .780$. (OEder. Dan. t. 219 . opt. Ger. em. 951. f. 3. Moris. bift. J. 4. t. 29.f. 23.)

Corn Crowfoot. Anglis.

In corn fields, but not common. Dr. Parfons. $\odot$. VI.

The ftalk is a foot high, ereet and branched: the flower is fmall, and of a pale yellow color : the nectariferous fcale is obfcurely heart-lhaped with an inflected margin, : the Stamina are about 14 or 15 : the feeds 6 or 8 , of a round and flatted figure, both fides echinated or covered with prickles, the marginal ones being the longeft and largeft. This laft criterion readily diftinguifhes the fpecies.

The juice of this kind is acrid like the preceding. An ounce of it given to a dog has killed him in three days, the ftomach being inflamed, corroded and bliftered.

bederacefus RANUNCULUS foliis fubrotundis trilobis inteI1. gerrimis, caule repente. $S p \cdot p l .7^{81}$. (CEder. Dan. t. 32 1. opt. Moris. bift. S. 4. t. 29.f. 29. Petiv. berb. t. $3^{8}$. f. I2)

Ivy-leav'd Water Crowfoot. Anglis. 
$I$ obferved it on the margins of Shallow rivulets, but not very fiequent, 2f. V-VII.

It is a dwarfin creeping plant, overrunning the rivulets in a mat : the leaves are fmooth, and fupported on long footftalks: the flower is fmall and white, growing one upon a peduncle, oppofite to the leaf: the Stamina are 5, and fometimes IO.

aquatilis 12. R. foliis fubmerfis capillaceis, emerfis fubpeltatis. Sp. pl. $78 \mathrm{~s}$. (Oed. Dan. t. 376. Jine fol. peitatis. benè. Ger. em. 829.f. 1. fol. peltatis. E $82 \% \cdot f .3$. fol. capillaceis tantium. Barrel. ic. 565 . fol. peltatis E capillaceis. ic. 566. fol. capirleceis tantum. Petiv. berb. t. 39.f. I, 2, 3, 4.)

Various-leav'd Water Crowfoot. Anglis.

In lakes, ditches and rivers frequent. $4 . \mathrm{V}$.

It varies with and without the peltated leaves: in

- itill waters they are commonly feen, but not in rivers: the Petrls are white, with yellow Ungues. They have no Scale, bu: only a melliferous Pore at their bafe, furrounded with a white circle. When in flower in the fpring it often makes the waters appear as white as fnow.

\section{TROLLIUS. Gen pl. 700.}

Col-o. Petala circiter 14. Caps. plurima, ovata, monofpermæ.

europous I. TROLLIUS corollis conniventibus, nectariis longirudine ftaminum. Sp. $p l .7_{-2}$ (Oed. Dan. $t$. 
133. opt. Moris. bift. S. 12. t. 2. f. 2. Ger. em. 955. f. 12)

Globe-Flower. Anglis.

Lucken-Gowan, i. e. Cabbage-Daifie. Scotis.

At the foot of mountains, and by the fides of their rivulets frequent; as at Drumianrig, the feat of the Duke of Queenfoury, in Nitbfdale; at CorrysLyn, the famous fall of the Clyde; and at Cartland rocks, near Lanerk, \&cc. Dr. Parfons likewife obferved it in Carubber-Den, two miles from Linlithgore, and in Achendenny wood. 2\%. VI.

The leaves are divided firft into five fegments down to the bafe; the fegments are again divided each about half way into two or three lobes, which lobes are fharply indented on the edges : the ftalk is a foot high, and fcarcely branched : the flower is yellow, globofe and fpecious: the petals 12 or 14 , difpofed commonly into four feries, within one another, and incurved, the exterior ones greenifh, and indented irregularly at the top: the Nestaria are in number from 9 to 16 , linear, plane, incurv'd, and perforated on the infide at the bafe.

The country people in Sweden ftrew their floors and pavements on holydays with the flowers, which have a pleafant fmell, and are ornamental in gardens. Our northern poet makes the young laird wifh to gather thefe flowers to weave a chaplet for his Katy's brow: 


\section{POLYANDRIA POLYGYNIA.}

Soon as the clear goodman of day

Bends his morning draught of dew,

We'll gae to fome burn-fide to play,

And gather flowers to bufk ye'r brow.

We'll pon the daifies on the green,

The Lucken-Gourans frae the bog,

Between hands now and then we'll lean,

And fport upo' the velvet fog.

Tea Table Mifceliany of Ailuz Ramiay, in a forg call'c,

The young Laird and Edirburgb Kat;

\section{HELLEBORUS. Gen. pl. 702.}

Cal. o. Petala 5, feu plura. Nectaria bilabiata, tubulata. Caps. polyfpermæ, erectiufculæ.

viridis I. HELLEBORUS caule multifloro foliofo, foliis digitatis. sp.pl. $7^{84}$. (Ger. em. 976. f. 2. Moris. bift. $.12, t .4 . f .5)$

Green-flower'd Hellebore. Anglis.

In Dunglass-Glen. Dr. Parjons. 4. IV.

The leaves are radical, and fupported on long footftalks; they are ftiff and nervous, and divided to the bafe into $g$ or 10 fpear-fhap'd lobes, feveral of which are again fubdivided half way down in. to two or three more, all of them tharply ferrated: the flower ftalk is a cubit high, dicbotomous, naked at the bafe, but has leaves fubtending the ramifications: each branch produces two nodding green flowers: the Nectaria are 8 or 10 in number, of the length of the ftyles, a little ferrated on the rims: the Stamina are 50 or more; the capfules from 3 to 5 . 


\section{POLYANDRIA POLYGYNIA.}

A drachm of the leaves reduced to powder is fometimes given to deftroy worms.

CALTHA. Gen. pl. $7 \circ 3$.

Cal. o. Petala 5. Nectaria o. Caps. plures, polyfperma.

paluftris I. CALTHA. $s p . p l .784$. (Ger. em. 817.f. I. Tabernamont. ic. 750 . Gefner. ic, an. 54.)

Marih Marigold. Angtis.

A' chorra-nhod. Gaulis.

In marthy grounds, and by river-fides frequent. 4. V.

The leaves are nearly kidney-hhap'd, crenated on the edges, and ftanding on footttalks: the ftalk is a foot high, and branched: the flowers ft and on fhort furrow'd peduncles, large and yellow: the Stamina are numerous, more than 100: the Capfules are from 10 to 14 , ftanding open and radiated.

The plant has an acrid quality, but the young flower-buds in fome parts of Germany are pickled and fold for capers. 


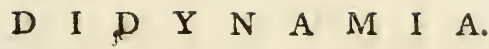

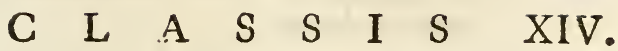

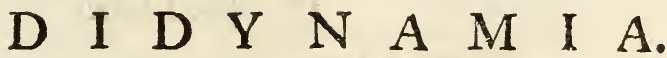

G Y M N OS P E R M I A.

* Calyces jubquinquefidi.

LECNURUS. Antbere punctis offeis adfperfa.

GLECOMA. Antherarum paria cruciata!

MENTHA. Filamenta diftantia recta.

TEUCRIUM. Corolle labium fuperius nullum, fed bipartitum!

A JUGA. Corolle lab. fuperius ftaminibus brevius ! BETONICA. Corolle lab. fuperius planum, afcen. dens, tubo cylindrico. Stamina longitudine faucis.

LAMIUM. Corolla lab. inferius utrinque dente fetaceo!

GALEOPSIS. Corolle lab. inferius fupra bidendatum 1

ST ACHYS. Corolle lab. inferius lateribus reflexum. Stam. deflorata ad latera deflexa.

NEPETA. Corolle lab. inferius crenatum. Faux margine reflexo.

BALLOTA. Calyx 10-ftriatus. Corolle lab. fuperius fornicatum. 


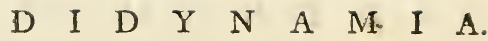

MARRUBIUM. Calyx 10-ftriatus. Corolle lab. fuperius rectum.

\section{** Calyces bilabiati.}

SCUTELLARIA. Calyx fructiferus operculatus!

THYMUS. Calyx fauce villis claufus.

PRUNELLA. Filamenta omnia apice bifurca!

ORIGANUM. Strobilus calyces colligens!

CLINOPODIUM. Involucrum calyces colligens.

\section{A N G I O S P E R M I A.}

* Calyces bifidi.

OROBANCHE. Caps. I-locularis. Cor. fubæqualis, 4-fida. Glandula fub baff germinis.

** Calyces quadrifidi.

LATHR 㤅A. Caps. 1-locularis. Cor. perfonata. Glandula fub germine.

BARTSIA. Caps. 2-locularis. Cor. perfonata. Cal. coloratus.

EUPHRASIA. Caps. 2-locularis. Cor. perfonata. Antbere inferiores hinc fpinofx.

RHINANTHUS. Caps. 2-locularis. Cor. perfonata. Caps. compreffa.

MELAMPYRUM. Caps. 2-locularis. Cor. perfonat3. Eem. bina, gibbofa.

* Calyces quinquefidi.

LIMOSELLA. 


\section{I D $\quad \mathrm{Y}$ N A $\mathrm{M}$ I A. उ०I}

LIMOSELLA. Caps. I-locularis. Cor. campanulata, regularis. Sem. plurima.

SCROPHULARIA. Caps. I-locularis. Cor. refupinata. $L a b$. fegmento intermedio interno.

DIGITALIS. Cups..2-locularis. Cor. companulata, fubtus ventricofa. Stam. declinata.

ANTIR RHINUM. Caps. 2-locularis. Cor. perfonata fubtus nectario prominente.

PEDICULARIS. Caps. 2-locularis. Cor. perfonata. Sem. tunicata. 


\section{L A S S I S XIV. \\ D I D Y N A M I A \\ G Y M N OS P E R M I A.}

AJUGA. Gen. pl. 705.

Corolle labium fuperius minimum. Stamina labio fuperiore longiora.

reptans I. AJUGA glabra, ftolonibus reptantibus, Lin. Sy/t. nat. $3^{87 . ~ S p . ~ p l . ~ 785 . ~(B l a c k w e l l . t ~ 64 . ~ b e n e ̀ . ~ M o-~}$ ris. bift. S. I . t. 5.f. r. ordinis inferioris. Rivin.t. 75. Ger. em. 631. f. 1. fine Jtolonibus. EO Pet. berb. t. $34 . f \cdot 3$ )

Bugle. Angiis.

In moift paftures and woods frequent. 24. V. VI. The fowering ftem is fix or eight inches high, erect and unbranched, but throws out trailing offsets from the root: ihe leaves are fmooth for the moft part, oval, bluntly crenated, and have large nerves: the flowers are ringent, and grow verticillate, eight or more in a whirl, commonly of a blue color, itreaked with veins of a deeper blue. The infide or throat of the flower is hairy.

pyramidaiis A. tetragona-pyramidalis villora, foliis radicalibus 2. 1 maximis. Lin. Jys. nat. 387 . Sp. pl. 785 . (Oed. Don. t. 185. Pct. lack t. 34.f.4. Rizin.t. $7^{6}$. 


\section{DIDYNAMIA GYMNOSPERMIA.}

Pyramidal or Mountain Bugle. Anglis.

In dry mountainous pattures, but rare. $\hat{o}$. V. VI.

I am affured by the Rev. Doctor Burge/s, of Kirkmicbael, that it is a native of Scotland, but I have not yet learned the particular place of its growth.

The ftalk is about four inches high, without offfets: the leaves are hairy, and grow upon the falk in fuch a manner as to make the whole plant form a quadrangular pyramid : the radical leaves are green, oval, and bluntly crenated; the Braktee, or floral leaves, are angular, and purple or violet-color'd: the flowers are pale blue.

\section{TEUCRIUM. Gen. pl. 706.}

Corolle labium fuperius (nullum) ultra bafin 2-partitum, divaricatum ubi ftamina.

forodonie I TEUCRIUM foliis cordatis ferratis petiolatis, racemis lateralibus fecundis, caule, erecto. $s p . p l$. 789. (Oed. Dan. t. 485. Blackwell. t. 9. Rivin. t. 12. Ger. em.662. Moris. bift.f. 11.t.20.f.15) Wood Sage. Anglis.

In woods and dry ftony places frequent, as about the rocks in the king'sıpark, \&c. 4. VII. VIII. The flowers are ftraw-color'd, the Filcments red: the plant has a bitter quality, and fmells like hops, with a litcle mixture of garlick. In the inand of Ferfey the inhabitants uie it in brewing infteaci of hops. An infufion of it itarids recommended in the dropfy. 


\section{NEPE'TA. Gen. pl. 710.}

Corolle labium inferius lacinula intermedia crenata, faux margine reflexo. Stamina approxinata.

cataria r. NEPETA floribus fpicatis; verticillis fubpedicellatis, foliis petiolatis cordatis dentato-ferratis. Sp. pl. 796. (Ger. em. 682. f. 1. Rivin. t. 52. Blackwell.t. 455. Pet. berb.t.32.f. I)

Cat-Mint. Anglis..

In hedges and wafte places. 24. VIII.

I infert this plant on Sibbald's authority only, not having found it myfelf.

The ftalk is a yard high, and branched: the leaves are hoary : the flowers are fiefh-color'd, growing verticillate in fpikes at the tops of the branches: the middle fegment of the lower iip is fpotted with red.

The plant has a bitter tafte and ftrong fmell, not unlike pennyroyal.

An infufion of it is reckoned a good Cepbalic and Emmenagogue, being found very efficacious in hyferics and the Chlorofis. Cats are extremely fond of this plant, whence the name.

MENTHA. Gen. pl. 7r3.

Corcila fubæqualis 4-fida; lacinia latiore emarginata. Stamina erecta diitantia.

- Capritate. 


\section{DIDYNAMIA GYMNOSPERMIA.}

equatica I. MENTHA floribus capitatis, foliis ovatis ferrats petiolatis, ftaminibus corolla longioribus, Lim. fyft. nat. 392. Sp. pl. 305. (Ger. em. 684. f. I. Moris. bift.S. 11. t. 7.f. 6. Rivin. t. 49. Blackwell. t. 32)

Water-Mint. Anglis.

Meannt. Cairteal. Gaulis.

On the banks of rivers and lakes frequent. 24. VIII. The ftalk is a cubit high, erect and branched : the leaves are often of a dark reddifh color: the flowers grow in one or two clofe thick whirls, near the top, with a globofe one always terminating the branches: the Corollo is hairy within, and of a pale red color.

The plant is aromatic, and has a bitter acrid tafte.

It varies, fometimes with a leffer, rounder, and more hairy leaf, as figured by Ray. Synops. $p$. 233. t. IO. f. I.

\section{** Verticillata.}

fativa * 2. MENTHA foribus verticillatis, foliis ovatis acu= tiufculis ferratis, ftaminibus corolla longioribus. Sp.pl. 805. (Ger. em. 68o.f. I. Moris. bifi. S. IIn t. 7.f. 2. ordinis Sutherioris.)

Red Garden Mint. Angiis.

On the banks of rivulets, and in wafte places, but rare, perhaps only the outcaft of gardens. Dr. Parfons ES Sibbald. 4. VIII.

gentiis 3. M. Aloribus verticillatis, foliis ovatis acutis ferratis, ftaminibus corolla brevioribus. 5 p., 1$) .805$. (Ger. 
em. 680.f. 4. Moris, bift. S. 1 1. t. 7.f. 1. ordinis Superioris.)

Red harp-leav'd Mint. Anglis.

On the fides of rivers and in wafte places, but rare. Dr. Parfons. 24. VIII.

The ftalks are red, the leaves nightly hairy, elliptical and acute: the whirls ten or more, continued from the middle of the branches to the top: the Calyces are fprinkled with refinous dots, and the lowermort fegment of the Corolla is acute.

arvenfis 4. MENTHA floribus verticillatis, foliis ovatis acutis ferratis ftaminibus corollam æquantibus. $s p . p l$. 806. (Oed. Dan. t. 512. Moris. bift. S. 11. t. 7. f. 5. ordinis Jecundi. fg. Secund. Ger. em. p. 684. f. 2.)

Corn Mint. Anglis.

In corn fields after harvelt, but not very common. 24. VIII. IX.

The whole plant is hairy: the falks recline on the ground: the whirls are downy, and much fhorter than the leaves: the Calyces hoary, the flowers of a pale blue, the loweft fegment of the Corolla obtufe.

The plant fmells much like the blue part of a decay'd cheefe.

Linnaus fays, that the milk of cows which have fed upon this plant can hardly be made to turn to curds.

pulegium*5 M. floribus verticillatis, foliis ovatis obtufis fubcrenatis, 


\section{DIDYNAMIA GYMNOSPERMIA.}

natis, caulibus fubteretibus repentibus, ftaminibus corolla longioribus. sp. pl. 807. (Ger. em. 671.f. 1. Moris. bift. .. 1 1. t.7.f. 1. ordinis secundi. Rivin. t. 23 . Blackwell. t. 302)

\section{Pennyroyal. Anglis.}

It is fometimes amongft rubbih thrown out of gardens, but probably is not a native. 4. VIII. IX. The whirls are fphærical, confifting of numerous peduncles, bearing each one or two flowers: the Caly $x$ is ftriated, a little inflated, and divided into five bearded dents, the lowermolt of which is the le्ft: the flowers are of a pale purple, or flefh color: the Stamina longer than the Corolla. An infufion of the plant in white wine with fteel is effeem'd an excellent emmenagogue.

\section{GLECOMA. Gen. pl. 714 .}

Antherarum fingulum par in formam crucis connivens. Calyx 5-fidus.

deracea 1. GLECOMA foliis reniformibus crenatis. $s p . p l$. 807. (Ger. em. 856. f. I. Rivin. t. 67. Vaill. Paris. t. 6.f. 4, 5, 6. Blackwell. t. 225)

Ground-Ivy. Anglis.

Under hedges and in fhady places frequent. 24. V. The lower part of the ftalks is procumbent, but the flowering part erect: the leaves are wrinkled and ftand on long femicylindrical footftalks : the joints are furrounded by a ciliated ring: the flowers are blue, and grow four or eight together, in half-whirls, leaning on one fide of the ftalk: 
the upper lip of the Corolla has a dorfal plait running down to the Calyx: the Antbere after burting ftand in the form of the letter $X$.

The leaves of this plant are often deformed with hairy tumors, which are the galls of the Cynips Glecome. Lin. Jy/t.n.

The juice or infufion of this herb has been recommenuled in gravelly and aftmatic complaints, but the fuccefs has not been found to anfwer the recommendation in any great degree.

In tome parts of England this plant is put into ale to purify and communicate to it its attenuant virtues.

\section{LAMIUM. Gen. pl. 716.}

Cor. labium fuperius integrum, fornicatum; labium inferius bilobum; faux utrinque margine dentato.

album 1. LAMIUM foliis cordatis acuminatis, ferratis, petiolatis, verticillis vigintifloris. Lin. Jy/t. nat. p.. 393. Sp. pl. 809. (Ger. em. 702.f. I. Blackwell. t. 33)

White Archangel, or Dead-Nettle. Anglis. Teanga-mhinn. Goulis.

Under hedges and in wafte places frequent. 2 . V. VI.

The Colyces are marked with a dark red fpot: the flowers are white, the tube of the Corolla curv'd nender at the bafe, and fhorter than the uppe? lip: the Antbere ciliated. 
The young leaves in the fpring are boiled and eaten as greens by the common people in Sweden.

purpureum L. foliis cordatis obtulis petiolatis. $S_{p}$. pl. 809 . 2. (Ger. cm. 703. f. 3. Moris. bift. f. 11. t. 11. f. 9 . Blackrvell. t. I. Oed. Dan. t. 52 3. opt.)

Red Archangel, or Dead-Nettle. Anglis.

In corn fields and gardens very common. $\odot . V$.

The ftalk is about fix inches high, almoft naked at the bafe, but crouded with leaves at the top: the flowers are red, the Antberce barb'd with white hairs.

This is alfo eaten in Sweden like the preceding.

amplexi. LAMIUM foliis foralibus feflilibus amplexicaulicoule 3. bus obtufis. Sp. pl. 80g. (Ger. em 6I6.f. 4. Rivin. t. 63. Moris. bift. f. 11. t. I1. f. 12. Pet. berb. $t .33 \cdot f \cdot 4)$

Great Henbic. Anglis.

In cultivated ground frequent. $\odot$. VI.

The lower leaves ftand on footitalks, are commonly divided into three lobes, and crenated on the edges : the upper leaves are very wide, feffile, deeply cut or lobed, growing oppolite, and touching each other at their bafe: the flowers are red, feffile, and giow ten or twelve in a whirl: the Gaiea or upper lip of the flower is oval. downy, and three times fhorter than the tube of the Coiolla.

$$
\text { X } 3 \text { GAIEOPSIS. }
$$




\section{GALEOPSIS. Gen. pl. $71 \%$.}

Corolla labium fuperius fubcrenatum, fornicatum; labium inferius fupra bidentatum.

tetrabit 1. GALEOPSIS internodiis caulinis fuperne incraffatis, verticillis fummis fubcontiguis, calycibus fubpungentibus. Lin. fyft. nat. p. 393. Sp. pl. 810. (Ger. em. 709. f. 1. Rivin. t. 31)

Nettle-Hemp, or Hemp-leav'd dead Nettle. Anglis. In corn fields and hedges. $\odot$. VIII.

The ftalk is erect, from two to four feet high, branched, covered with rigid hairs, and gouty juft under the joints: the leaves are of an ovallanceolate figure, nervous, ferrated, and fupported on footfalks: the flowers are either purple or white, with a fpot on the lower lip, varigated with purple and yellow: the Corolla is twice as long as the Caljx $x$.

var. $\beta$. There is a very beautiful variety of this common in corn fields, with large yellow flowers, four times as long as the Calyx, having the middle fegment of the lower lip purple. This is made by Haller a diftinet fpecies. (vid. fig. Rivin.t. $3^{2}$. Barrelier ic. 11 58. Ger. em. 709. f. 2 ? Pluk.t. 4I. $f \cdot 4$ )

galeobdolon 2.

GALEOPSIS verticillis fexfloris; involucro tetraphyllo. Sp.pl. 8 10. (Ger. em. 702. f: 2. Rivin. t. 20. Mor. bift. S. I . $t$. I I. f. 5. Pet. berb.t. $33 . f \cdot 6)$ 


\section{DIDYNAMIA GYMNOSPERMIA.}

Yellow Archangel. Anglis.

In woods and fhady places in the lowlands, but not common. 24. V. VI.

The root throws out long procumbent offsets: the leaves are oval and oblong, and doubly indented: the flowers are large and yellow, and grow from ten to eighteen in a whirl: the upper lip is longer than the lower, erect, and nightly crenated at the top: the lower lip is trifid, the lateral fegments being quadrangular, the middle one longeft, and mark'd with faffron-color'd ftreaks. 'This fpecies is rank'd under the genus of Leonurus, by Scopoli, in his Flor. Garniol. No. 715 . and under Cardiaca, by Haller, bift. No. 275 .

\section{BETONICA. Gen. pl. $7 \mathrm{I} 8$.}

Cal. ariftatus. Corolle labium fuperius afcendens, planiufculum; tubus cylindricus.

offinalis I, BETONICA fpica interrupta, corollarum lacinia labii intermedia emarginata. sp. pl. 8ı. (Ger. en. 714. f. I. Rivin. t. 28. Blackwell. t 46. Moris. bift. S. I I. t. 5. f. 1. ordinis Juperioris ad finifram. Pet. berb. t. 32.f. 6)

Wood Betony. Anglis.

In woods and or dry banks, but not common. Upon a bank near Ecblin, above the Queen'sFerry, in Weft-Lotbion, \&c. Sibbald. 4. VIII.

The ftalk is a foot high, erect, and generally unbranched: the radical leaves ftand on footfalks, bluntly heart-Ihap'd, wrinkled and crenated : the uppermott 


\section{DIDYNAMIA GYMNOSPERMIA.}

uppermoft are oval and feffile : the flowers grow in whirls, forming a fhort fpike at the top of the ftalk: the Bractece are of an oval-lanceolate form, and fhorter than the flowers : the Calyx ftands rather ereet, divided into two lips, and having the 2 upper dents recurv'd : the flowers are red, ftanding open and horizontal, and about i4 in a whirl: the tube of the flower is twice as long as the Caiyx, and the Filaments are hairy.

var. $\beta$. There is a fmall mountainous variety of this not unfrequent, with a fpike nearly globular. (vid. Moris. bif. S. 1 1. t. 5.f. 4. ordinis Juperioris)

The roots in a fmall dofe have an emetic quality, and the powder of the dry'd plant is a good Err. bine, and readily prometes fneezing.

\section{STACHYS. Gen pl. 719.}

Corolle labium fuperius fornicatum; labium inferius lateribus reflexum; intermedia majore emarginata. Stamina deflorata verfus latera reflexa.

fyliaica $\mathrm{x}$.

STACHYS verticillis fexforis, foliis cordatis petiolatis. Sp.pl. 81 . (Ger. em. 704. f. 5. Rivin.t. 26. Blackwell t. 84. bona. Moris. bift. Y. I1. t. I1. f. io Petiv. berb. t. 32. f. 7.)

Hedge Nettle. Anglis.

In woods and thady places not uncommon. $\odot$. VII. VIII.

The whole plant is hairy, erect, a yard high, and branched: the hairs are jointed: the flowers are of a deep red color, growing fix or eight in a whirl, 
whirl, continued into a long fpike, deftitute of leaves : the upper lip is downy, erect and coved, and ftreaked with three deeper-color' ${ }^{3}$ lines: the middle fegment of the lower lip is variegated with white and red waved lines. The whole plant has a ftrong fœtid fmell.

aluftris 2. S. verticillis fexfloris, foliș lineari-lanceolatis femiamplexicaulibus. Sp. pl. Sis. (Ger. em. 1005. Rivin. t. 26. Blackwell. t. 273. Loes. Flor. PruJ. ic. 4 1. Moris. bift. S. 11. t. 10. f. 16. Pet. berb. t. $33 \cdot f \cdot 9 \cdot)$

Clown's All-heal. Angiis.

B̂y the fides of rivers and lakes, and in low moift grounds not uncommon, and fometimes in corn fields. 24. VIII.

The roots are white and tuberous : the ftalk two $\mathrm{or}_{-}$ three feet high : the flowers are red, growing in whirls, lengthened into a fpike, commonly fix, but fometimes ten or twelve in a whirl : the middle fegment of the lower lip of the Corolle is variegated with fpots of a deeper color than the reft of the flower.

It has a fœtid fmell and bitter tafte, and is reckon'd a good vulnerary. Swine are fond of the roots, which are fweet, and in times of neceflity they have been eaten by men, either boiled, or dry'd, and made into bread.

arvenfis 3. STACHYS verticillis fexfloris, caule debili, foliis obtufis nudiufculis, corollis calyce vix longiorlbus. 
bus. Sp. pl. 814. (Rivin.t. 27. Pet. berb. t. 33 . f. 12.)

Petty Ironwort, or All-heal. Anglis.

In com fields frequent. $\odot$ : VIII.

The ftalk is ten or twelve inches high, fquare, branched and hairy: the leaves are heart-fhap'd, obtufe, bluntly ferrated, and lefs hairy : the $\mathrm{Ca}_{a}$ lyces are hairy and feffile, and deeply divided into five acute dents, of equal length : the flowers are flefh-color'd, and grow three, four, or five in a whirl: the lowes lip is trifid, the middle fegment fpotted with red, but not emarginated according to the character of the Gonus.

\section{BALLOTA. Gen. pl. 720.}

Cal. hypocrateriformis, quinquedentatus, decemitriatus. Corolla labium fuperius crenatim, concavun.

BALLOTA foliis cordatis indivifis ferratis, calycibus acuminatis. sp. pl. 8i4. (Ger. em. 70 I. f. I. Rivin. t. 66. Blackwell. t. Ij6. Moris. bift. S. II. t. 9. f. 14. Pet. berb. t. 32. f. 4)

Stinking Horehound. Anglis.

In wafte places near towns and villages, but not common. Dr. Parfons E Sibbald. 2. VIII.

The flowers grow in whirls, upon branched peduncles, and lean on one fide of the ftalk: they are commonly of a dull red color, but fometimes white.

The plant has a ftrong foetid fmell, and has been fometimes 
fonetimes recommended in hyfteric cafes, but is at prefent little ufed.

\section{MARRUBIUM. Gen. pl. $72 \mathrm{I}$.}

Cal. hypocrateriformis, rigidus, ro-ftriatus. Corolle labium fuperius 2-fidum, lineare, rectum.

vulgore I. MARRUBIUM dentibus calycinis fetaceis uncinatis. Sp.pl. 8 16. (Ger. emac. 693. f. 1. Rivin.t. 67. Blackwell. t. 479. Pet. berb. t. 32. f. 3.) White Horehound. Anglis.

In wafte places and by way-fides near towns and villages, but not common, as about Burntifland, \&c. 24. VIII.

Several rigid erect ftalks arife from the root a cubit high : the leaves are of a bluntly oval or rounded form, deeply wrinkled, hoary, and srenated on the edges: the flowers are white, and grow in thick feffile whirls, fifty or more in each. The mouth of the Caly $\approx$ is downy, and fubtended by linear Bractece : the middle fegment of the lower lip of the Corolla is crenulated: the flowers fade without falling out of the Calyces.

It has 2 ftrong and fomewhat muky fmell, and bitter tafte. It is reputed attenuant and refolvent. An infufion of the leaves in water, fweetened with honey, is recommended in afthmatic and pthificky complaints, and moft other difeafes of the breaft and lungs. 


\section{LEONURUS. Gen. $p l$. $; 22$.}

Antbere punctis nitidis adfperfe.

Cerdiace" I LEONURUS foliis caulinis lanceolatis trilobis.

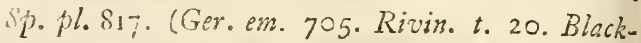
well. t. 171. Miller. ic. 80.)

Motherwort. Anglis.

It is fometimes found amongft rubbin near houfes, but is probably only the ourcaft of gardens. oै ? VIII.

The ftalk is a yard high or more, and much branched: the flowers are of a pale red, and grow in thick fefile whirls : the Calyx is ftreaked with five green lines, and every exterior one fubtended by a fetaceous Braftea: the upper lip of the Corolla is entire, and externally hairy: the middle fegment of the lower lip is marked with red fpots: the filaments are hairy, and the Antbere have fometimes three or four white round feninal particles to be feen upon them, which Linnous has made the characteriftic of the genus. Thefe particles are however lefs confpicuous in this than in the other fpecies of this family.

\section{CLINOPODIUM. Gen. pl. 725 .}

Incolucrum multifetum, verticillo fubjectum.

vuigare $\mathrm{I}$.

CLINOPODIUM capiculis fubrotuncis hifpidis, brakteis fetaceis. Sp. pl. S21. (Ger. em. 675.f. 2. kivin. t. 43 . horis. bift. S. 8. t. I $1 . f$.. ordinis juperioris. Pet. berb.t. 32. f. 9)

Great 


\section{DIDYNAMIA GYMNOSPERMIA.}

Great Wild Bafil. Anglis.

In woods and dry expofures, but not very common.

I obferved it in the woods about Dunkeld, and at Duplin, and Dr. Parfons found it in Coryton woods, near Edinburgh. In Buden hill, near the Kippis, in Wefi Lothinn. Siobald. 24. VIII.

The whole plant is hairy and foft to the touch, about a foot and a half high: the leaves are oval, and farcely indented: the flowers are of a pale red, growing in thick whirls ( 40 in a whirl) on branched peduncles, one of the whirls always terminating the thalk and branches: the Calyx is very hairy, and the Corolla prominent and much longer than the Calyx.

The fmell of this plant is fomewhat aromatic, and not unpleafant.

\section{ORIGANUM. Gen. pl. 726.}

Strobilus tetragonus, fpicatus, calyces colligens.

vulgare 1 .

ORIGANUM fpicis fubrotundis paniculatis conglomeratis, brakteis calyce longioribus ovatis. $s_{p}$. pl. 824. (Ger. em. 666.f. 4. Rivin.t. 60. Blackwell. t. 280 . Moris. bift. J. 11. t. 3. f. 12. Pet. berb. t. 34.f. 8)

Wild Marjoram. Anglis.

In dry mountainous and rocky places, as about Dunkeld, Duplin, and in the den of Betbaick, near Perth, 8rc, 24. VIII.

The ftalk is round, a cubit high, and branched: the 
the leaves are a little hairy, nearly oval, punctated, and entire on the edges: the flowers are generally red: the Bractea oval and red likewife: the Stamina are longer than the flower.

The fmell is aromatic; the tafte fomewhat acrid: it ftands recommended in afthmatic complaints, but is rarely ufed.

It dyes yarn of a deep red color.

In forne parts of sweden the common people put it into their ale to give it an intoxicating quality, and to prevent its turning four.

\section{THYMUS. Gen. pl. 727 .}

Calyces bilabiati, faux villis claufa.

ferpyllum $\mathrm{I}$.

THYMUS floribus capitatis, caulibus decumbentibus, foliis planis obtufis bafi ciliatis. $s p \cdot p l .825$. (Ger. em. 570. f. . Vaill. Paris. t. 32. f. 7, 8, g. Moris. bift. f. 11.t. 17.f. 1. ordinis fuperioris. Rivin t. 42)

Mother of Thyme. Anglis.

Lus-mhic-ri-Breatuinn. Goulis.

In dry mountainous places common. 24. VII. VIII.

var. f. There is a variety of this plant frequent, with the leaves and ftalks all over hairy. (vid. Veill. Paris. t. 32. f. 6. Ger. ein. 571.f. 8)

var. $\gamma$. There is yet another variety, having the fummits of the brunches formed into woolly heads: this is occafioned by a fpecies of infect of the Chermes 
kind. The fame thing is frequently obvious in the Veronica cbamedrys, Ceraftium, E' Glecoma.

The flowers of thyne are commonly of a bright purple, but they vary much both in fize and color.

It has a pleafant aromatic fcent, and is efteened a good nervine. An infufion of it by way of tea is reputed to be an almot infallible cure for that troublefome diforder, the Incubus, or Night-mare.

ecinos 2. THYMUS foribus verticillatis, pedunculis unifloris, caulibus erectis fubramofis, foliis acutis ferratis. Lin. Jyf. nat. 399. Sp. pl. 826. (Ger. em. 6-5. f. I. Rivin. t. 43. Pet. herb. t. 32, f. 10. Moris. bift. f. I I. t. 18. f. I. ordinis Juperioris) Small wild Bafil, Anglis.

In dry mountainous places, and gravelly foils, but not common. $\odot$. VIII.

The ftalk is rigid and branched: the leaves are oval and acuminated, indented above the middle, but entire at the bafe: the Calyx on the under fide bulges at the bafe, and is ftreaked with eleven ciliated ridges. They grow from five to eight in a whirl. The flower is violet-color'd, the middle fegment of the lower lip fpotted with white or yellow.

The whole plant has a pleafant aromatic fmell.

$$
\text { SCUTELLARIA. Gen. pl. } 734 .
$$

Calyx ore integro, poft florefcentiam claulo, operculato. 
galericu-

lato I.

SCU TTELLARIA foliis cordato-lanceolatis crenatis, floribus axillaribus. Sp.pl. 835. (Ger.em. 477.f. 10. Rivin. t. 77. Pet. berb. t. 34.f. 10) Blue Scull-cap, or hooded Willow herb. Anglis.

On the fides of rivers and lakes not uncommon. 24. VIII.

The ftalks are erect, a cubit high, quadrangular, and branched: the Caijx confifts of two leaves, reprefenting a helmet or cap, which affords an excellent characteriftic to the genus: the flowers are blue, and grow in pairs from the Alce of the leaves, both looking horizontally on the fame fide of the ftalk. The lower lip of the Corolls is fpotted with white.

The plant is bitter, and has a garlick fmell.

minor 2. S. foliis cordato-ovatis fubintegerrimis, floribus axillaribus. Sp.pl. 835. (Ger. em. 58 i.f. 3. Moris. hift. . 11. t. 20.f. 8. ordinis inferioris. Pet. berb. t. 34.f. 11.)

Little red Scull cap, or Willow-herb Anglis.

On the fides of lakes and in boggy plitces not unfrequent. 24. VIII.

This is about five or fix inches high, and the flowers pale red.

\section{PRUNELLA. Gen. p. 735.}

Filcmente bifurca, altero apice antherifera. Stigia bifium.

PRUNELLA. 



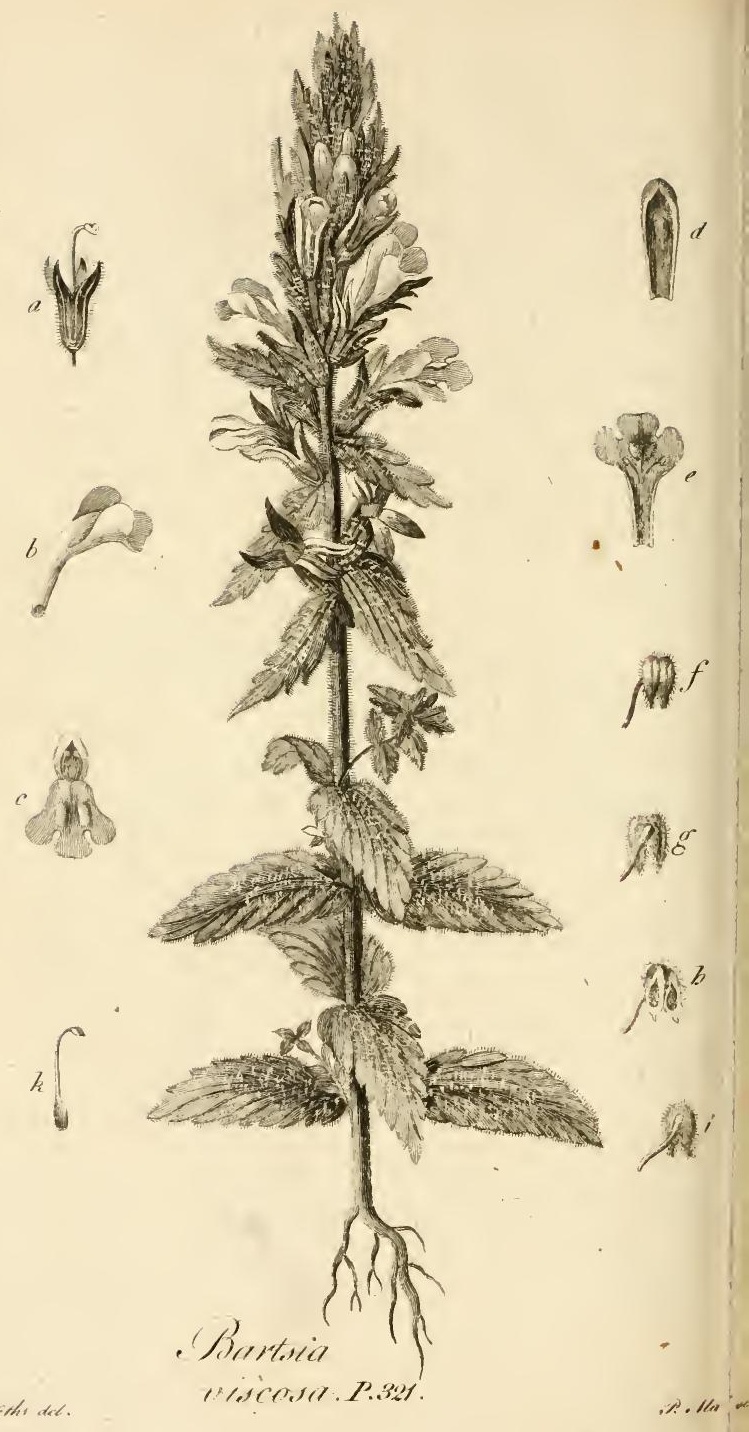


vulgaris I. PRUNELLA foliis omnibus ovato-oblongis petiolatis. sp.pl. 837. (Ger. em. 632. f. I. Miller ic。 70. f. 2. Rivin. t. 29. Blackwell. t. 24. Moris. hift. f. 11.t. 5.f. 1. ordinis Juperioris ad dextram. Pet. berb.t. 32.f. II.)

Self-heal. Anglis.

In moift and barren paftures frequent. 24. VIII. The ftalk is branched, from fix to twelve inches high: the flowers grow in clofe cylindrical heads or fpikes, at the fummits of the branches: the upper lip of the Calyx is truncated, and has three fhort bearded dents : the lower lip is bifid, and the dents bearded : the Braitez are heart-fhap'd, and both thofe and the Caiyces hairy : the Corolla is generally of a blueifh purple, but often varies in color: the lips of the Calyx clofe together, after the flower falls, in order the better to fecure the embryo feeds.

It is aftringent and vulnerary, but is rarely ufed at prefent, except by the common people, who bruife and apply it to frefh wounds, and take it in broths and apozems for fpitting of blood, and ufe it by way of injection in the Bioody-Flux, and other Hamorrbages.

\section{A N G I O S P E R M I A. BARTSIA. Gen. pl. 739 .}

Cal. bilobus, emarginatus, coloratus. Corolla minus ipfo calyce colo: ata, labio fuperiore longiore. írofa. - BARTSIA foliis fupericribus alternis forratis, fo- 
ribus diftantibus lateralibus. Lin. fyft. nat. $405^{\circ}$. Sp. pl. S39. (Pluk. alms. t. 27. f. 5. Barrcl.ic. 665. Pit. berb.t. 36.f. 6)

Yellow Marn Eye-bright. Anglis.

In boys and marfhes, but rare, as about Locb-Goyl near Locb-Long, in the diftrict of Cowal, in $A r-$ gylefhire. $\odot$. VIII.

The ftalk is erect, about ten or twelve inches high, downy and unbranched : the leaves are feffile and fpear-fhap'd, and a little vifcous : the Calyces are vifcous, and grow fingle from the Ale of the leaves: the flowers are yellow: the plant dries black.

RHINANTHUS. Gen. pl. 740.

Cal. 4-fidus, ventricofus. Capfula 2-locularis, obtufa, compreffa.

crifla galli. RHINANTHUS corollis labio fuperiore compreffo breviore. Lin. Jyft. nat. 405. Sp. pl. 840. (Ger. ein. 107 1. fig. Juprema. Rivin. t. 92. Moris. hift. .1 I. t.23.f. I. ordinis secundi)

Yellow.Rattle, or Cock's-Comb. Anglis.

In meadows and dry paftures common. $\odot$. VII. The whole plant is fnooth, and about a foot high: the leaves are feffile, of an oval-lanceolate figure, and ferrated: the flowers are yellow, and grow in fol aceous fpikes, leaning on one fide of the thalks : the Colvx is large, roundinh, compreffed. inflated, and has four dents: the Galea, or up. per lip has bific auricles of a blueifh color: the capfules and feeds have a membranaceous margin

Thert 


\section{DIDYNAMIA ANGIOSPERMIA.}

var. $\beta$. There is a pretty variety of this with a fmaller flower, and the lower lip purple.

The feeds of both, when ripe, rattle in their capfules, and indicate the time of hay-harveft.

It has a bitter and fomewhat acrid tafte, but is eaten by cattle.

\section{EUPHRASIA. Gen. pl. 741 .}

Cal. 4-fidus, cylindricus. Caps. 2-locularis, ovatooblonga. Antberce inferiores altero lobo bafi fpinofx.

- ffcinalis I. EUPHRASIA foliis ovatis lineatis argutè dentatis. Sp.pl. 841. (Ger. em. 663. Rivin. t. 90. Blackwell. t. 427 . Moris. bift. S. Is. t. 24.f. I)

Anglis. Eyebright.

Gaulis. Rein-an-ruifg.

In dry barren paftures frequent. $\odot$. ViI.

The plant is from three so fix inches high, ereet, and branched: the leaves grow oppofite, feffile, and in pairs: the flowers grow from the Alce of the leaves, on thort footftalks, forming a fpike at the fummits of the branches: the Corolla varies in color, but the upper lip is generally purplifh, ftreaked with lines, the lower lip white and ftreaked, and marked with a yellow fpot at is bafe.

it has been reputed good for fore eyes, but the gentlemen of the faculty have declared it does more harm than good in applications of that kind, there having been inftances of perfons rendered 
324 DIDYNAMIA ANGIOSPERMIA.

almoft blind by the ufe of it The highlanders do however ftill retain the practice of it, by making an infufion of it in milk, and anointing the patient's eyes with a feather dipped in it.

odonitites 2. EUPHRASIA foliis linearibus, omnibus ferratis. $s p$. pl. 84r. (Ger. em. 91.f. 3. Moris. bift. S. I I. t. 24. f. 10. Pet. berb. t. $3^{6 . f .7 .)}$

Red Eye-bright. Anglis.

In Corn fields and by way fides not uncommon. $\odot$. VIII. IX.

The ftalk is erect, greatly branched, and ten or twelve inches high. The flowers are red and grow in fpikes, all leaning on one fide of the branches. The Antberce are ferrugineous, having all their lobes alike acuminated.

The whole plant has commonly a reddin or fufcous appearance.

\section{MELAMPYRUM. Gen. pl. 742 .}

Cal. 4-fidus. Corolle labium fuperius compreffum, margine replicato. Caps. 2-locularis obliqua, hinc dehifcens. Semina duo, gibba.

pratenfe 1. MELAMPYRUM floribus fecundis lateralibus; foliorum conjugationibus remotis, corollis claufis. Lin. Jyf nat. 406. sp.pl. 843. (Hortus Aichflett. affiv. ord. 12.t.2.f. 2.

Meadow Cow-wheat. Anglis.

In dry mountainous paftures and woods not uncommon. $\odot$. VII.

The ftalk is a foot or eighteen inches high, horizontally 


\section{DIDYNAMIA ANGIOSPERMIA.}

tally branched. The lower leaves are of a narrow fpear-Thaped form, and commonly intire. The middle ones have a $\mathrm{ftw}$ large dents at their bafe, but are often intire. The upper foral ones are halbert-haped or trifid, having the dents or hooks at the bafe reflexed. The flowers grow in pairs from the Ale of the leaves, feffile, and turned to the fame fide of the ftalk. The corolla is white, except the Galea which is yellow, with a pale margin; and the lower lip is marked with two prominent deep yellow dots. The tube of the corolla is long, white, nender and wrinkled; the lips of it are clofed together like the mouth of a filh. The Antberie cohere together. Linnaus tells us, that where this plant abounds, the yelloweft and beft butter is made.

Gylvaticum 2.

MELAMPYRUM floribus fecundis lateralibus, folorum conjugationibus remotis, corollis hianttibus. Lin. Syjt. nat. 406. Sp.pl. 843. (Ger. em. 91.f. I. Moris. bift. S. 11.t. $23 \cdot f \cdot 3 \cdot$ floribus inapertis. Oed.Dan. t1. 45. cum floribus aper. tis. optimè.)

Yellow Cow-wheat. Anglis.

In woods, but not common. $\odot$. VII.

The leaves in this kind are generally quite intire. The flowers not above half fo long as in the preceding, their lips not clofed together, but gaping open, and the whole Corolla 'tube and all) of a deep yellow colour.

$$
\text { Y } 3 \text { LATHRAA. }
$$




\section{DIDYNAMIA ANGIOSPERMIA.}

\section{LATHRÆA. Gen. pl. 743 . \\ Cal. 4-fidus. Glandula depreffa ad bafin futura germinis. Capfula I-locularis.} Squamaris LATHREA caule finpliciffimo, corollis pendulis, labis inferiore trifido. Sp.pl. 844. (Moris bift. f. 12. t. 16. f. 14. Rivin. t. 89. Blackwell t. 430. Oed. Den. t. 136. opt.)

Tooth-wort. Anglis.

In woods and Mady Places, but not common.

At the end of a hady walk by the river fide at $\mathrm{Me}_{\mathrm{e}}$ vis Bank towards Lafwade, four or five miles from Edinburg. Dr. Parfons. And in Morvern, near the found of Mull, on a dry heathy brae, to the eaft of the houfes of Laggan. Mr. Stuart. 4. IV. V.

The root is branched, and furrounded with white fucculent fcales. The ftalk is embranched, and deftitute of leaves. The flowers grow in a fpike all on one fide of the ftalk. The Bractea, which fubtend the flowers, are large, roundinh, flefhcolored fcales. The Calyx hairy and whitifh. The Corolla pale purple, or flefh-color'd, the lower lip white, and trifid, the upper one incire. The whole plant is brittle and fucculent, and probably parafitical, as it will not bear tranfplanting.

\section{PEDICULARIS. Gen. pl. 746.}

Cal. 5-fictus. Caps. 2-locularis, mucronata, obliqua.

Semina tunicatar

perufris s. PEDICULARIS caule ramoro, calycibus criftatis callofo punctatis, corollis labio obliquis. Lin. Sy. 


\section{DIDYNAMIA ANGIOSPERMIA.}

Sy.t. nat. 407. ip.pl. 845. (Rai. 1. R. H. t. 77. A. D. E. н. I. K. L. Pet. kerb. t. $3^{\text {G. } f . ~} 3$.

Marfin Loufewort. Ang'is.

By the fides of lakes, and in bogs fiequent. $\odot .7$. The ftall: is erect, a cubit high, and branch't. 'The leaves are pinnated wirh about 20 pair of long Pinne, which are again femipinnate with thort indented Pinnula. The flowers grow in a loote fpike from the Ale of the leaves, on thort footftalks. The Calyx is reddin, a little hairy, comprefs'd fideways, bulging at the bare, and has two of the fegments crifted, or terminated with leaf-like appendages. The flowers are purple.

fylvatica 2. PEDICULARIS caule ramofo, calycibus oblongis angulatis levibus, corollis labio cordato. Sp. pl. 845. (Ger. em. 1077. fig. inferior. Moris. bifl. f. 11. t. 23.f. 13. Pet. berb. t. 36.f.4. Oed. Dan.

\section{t. 225 . opt.}

Common dwarf Loufewort. Anglis.

In wet paftures and heaths frequent. $\odot$. VI.

The ftalks lie proftrate on the ground: the leaves are fimply pinnated, with roundinh, acutely ferrated pinina. The flowers grow in a clutter at the top of the plant and fparingly on the branches, feffile, and of a pale purple or red color. The lower dent of the Calyx is very fnall, the others are crifted.

Thefe plants are rarely eaten by cattle, but when they are, they are fuppos'd to nake them loufy, whence the name. 
If this effect really follows, it is more probably ow. ing to the poverty of the foil where the plants grow, than to any particular quality in the plants themfelves.

ANTIRRHINUM. Gen. pl. 750.

Col. 5-phyllus, Corolla bafis deorfum prominens, nectarifera. Caps. 2-locularis.

* Foliis alsernis floribus calcaratis.

linaria I. ANTIRRHINUM foliis lanceolato-linearibus confertis, caule erecto, fpicis terminalibus feffilibus, floribus imbricatis. Sp. pl. 858 . Ger. em. 550.f. 1. Rivin. $t$. 83. Rlackrvell t. 115.)

Common yellow Toad-flax Anglis.

On the borders of corn-fields in many places, as in Strath-Tay, and between Dunkeld and Blair, Eंc. 4. VIII.

The ftalk is 3 or 4 feet high, and often branch'd. The leaves fmooth and glaucous: the flowers are yellow, and grow in fpikes, at the tops of the ftalk and branches. The palate of the Corolla is hairy and orange-color'd.

$\beta$ peloria. There is a variety of this plant fometimes found, the Corolla having from two to five fpurs, and the limb affuming a regular pentapetalous appearance; but this is only a monftrous luxuriance, as is evident from both kinds being upon the fame plant. (vid. fig. Aman. acad. I. 282.t. 3.) An ointment made of the leaves ftands recommended as a cure for the piles.

This is the only fpecies of Antirrbinum that I obferv'd growing wild in Scotland.

SCRO- 
SCROPHULARIA. Gen. pl. $75^{6}$.

Cal. 5-fidus. Cor. fubglobofa, refupinata. Caps. 2locularis.

nodofa. I. SCROPHULARIA foliis cordatis trinervatis caule. obtufangulo. Lin. Jyf. nat. p. 4'3. . p. pl. 863 . Ger.em. 716.f. 1. Rivin. t. 107. Backwell. t. 87. Moris. hift. S. 5.t. 8. f. 3. ordinis inferioris. Pet. berb. $t$ 35.f. o.)

Knobby-rooted Fig-wort. Anglis.

In woods and moift ground not unfrequent. $\boldsymbol{\Psi}$. VII.

The root is tuberous: the ftalks are 4 or 5 feet high, and branch'd towards the top : the leaves heart hap'd, ferrated, and acute. The flowers are of a dark red color, fhaped like a cap or helmet, the lower lip greenith: they grow in loofe dichotomous fpikes or Racemi. At the top of the branches.

The leaves have a fœtid fmell, and hitter tafte. A decoction of them is faid to cure hogs of the mealles.

An ointment made of the root has been formerly ufed to cure the piles and fcrophulous fores, but is at prefent out of practice.

aquatisa. 2.

SCROPHULARIA foliis cordatis obtulis petiolatis decurrentibus, caule membranis angulato, racenis terminalibus. Lin. Jy/t. nat. 4'3. Sp. pl. 864. Ger. em. 715. Loes. Fior. Prufs. 24i3. ic. 75. Blackwell t. 86. Moris bift. S. 5.t.9.f.4. ordinis inferioris. 


\section{DIDYNAMIA ANGIOSPERMIA.}

inferioris. Pet. berb. t. 35. f. 10. Oed. Dan.t. 507. optimiè.)

Water Fig-wort, or Betony-leav'd Figwort. Anglis.

On the fides of rivulets and other wet places. Dr. Parfons E Sibbald. 24. VII.

The root is fibrous, the ftalk quadrangular, the an. gles membranaceous : the flowers are of a dark red, or blood color, growing in loofe fpikes on branched angular penduncles.

It has a fœtid fmell, but not fo ftrong as the preceding.

rernalis * 3 SCROPHULARIA foliis cordatis, caulinis ternis, pedunculis axillaribus folitariis bifidis. Lin. Man. tiss. plantarum altera p. 418. sp. pl. 864. (Ger. cm. 717.f. 3. Rivin. t. 107. Barrelier. ic. 273: Bauh. Prod. t. 112. Oed. Dan. t. 411. benè.)

Yellow Fig-wort. Anglis.

I obferv'd it about Hoddan caftle in Annandale; but probably it was only the outcart of a garden. o. V.

The ftalk and leaves are hairy: the flowers oval and yellow.

\section{DIGITALis. Gen. pl. $75^{8}$.}

Cal. 5-partitus. Cor. campanulata, 5-fida, ventricofa. Cops. ovata, 2 locularis.

furfurca 1.

DIGITALIS calycinis foliolis ovatis acutis, cotol-

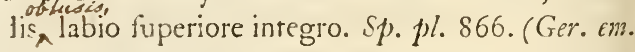
790 f. I. Tournef t. T3. A. E. F. K. L. M. Rivin. 104 Blackwell t. 16. Moris. hift. \% 5. t. 8.f. 1. 
ordinis fuperioris. Oed. Dan. t. 74. opt.)

Purple F/ox-glove. Anglis.

Meuran-fith. Gaulis.

In rough mountainous places not uncommon, as upon the Corftorpbyn hills near Edinburgh́, and on the hills about Locb-Rannocb in Pertb/bire, and many other places $\hat{\sigma} \mathrm{VII}$.

The ftalk is 3 or 4 feet high, ereet, and generally unbranched. The leaves are of an oval-lanceofate form, foft and hairy, and ferrated on the edges.

The flowers grow pendulous, in a long fpike, all on the fame fide of the ftalk. They are of a purple color, very fpecious, and marked internally with pupillary fpots. It fometimes varies with white flowers, but very rarely.

The plant has a bitter quality: fix or feven fyoonfulls of the decoction is a ftrong emetic and cathartic. It has been found ferviceable in fc\$rophulous cafes, taken internally for fome time, and the bruifed leaves or an ointment applied outwardly.

\section{LIMOSELLA. Gen. $p l .776$.}

Cal. 5 fidus Cor. 5-fida, æqualis. Stam. per paria approximata. Caps. I-locularis, 2-valvis, polySperma.

aquatica I. LIMOSELLA. Sp. pl. $88 \mathrm{r}$. Moris. bift. $\int .15 . t$. 2. т. Pluk. a!m. t. 74.f. 4. Pet. berb. t. $65 . f$. 12. Loes. Prufs. 216. t. 18. Mentz. pug. 2. t. 7.f. 6. Oed. Dan. t. 6g. opt.) 
Baftard Plantain. Anglis.

In muddy and gravelly places, where water has ftagnated in the winter, but not very frequent. $\odot$. VIII. IX.

It is a minute creeping plant, producing fmooth elliptic leaves in tufts, ftanding on very long footftalks. The flower-ftalks are radical, much thorter than the leaves, and produce each a fingle fmall white flower, of a regular figure, a little hairy and reddifh within, containing 4 ftamina, growing in pairs, two a little higher than the others. The ftyle declines to one ficie of the corolla. The capfule is nearly round.

\section{OROBANCHE. Gen. pl. 779.}

Cal. 2 - Fridus. Cor ringens. Caps. I-locularis, 2-valvis, polyfperma. Glandula fub bafi germinis.

major. 1. OROBANCHE caule fimplicifinio pubefcente, ftaminibus fubexfertis. Sp. pl. 882. (Ger. em. 131.f. 2. Moris. Hift. S. 12.t.16.f.1.) Broom-rape. Anglis.

In dry pafture, but rare. Upon the buck of Burntifland. Sibbald.

The root is a parafitical bulb, covered with ovallanceolate fcales. It adheres by a fibre to the root of fome other plant, commonly of the Diadelpbous kind, fuch as broom, \&c. The ftalk is 10 or 12 inches ligh and fiefluy, having no other leaves than frales, like thofe of the root. The flowers grow in a long cylindrical fpike, each fubtended by an oval-lanceolate fale or brailec. 
The Calyx in this fpecies is divided only into 4 fegments, two longer, and two fhorter. The Stamina do not project out of the Corolla. The Antbere cohere together. The Stigna is yellow, and bluntly heart-Ihap'd.

The whole plant is of a brown or fuillemort colour.

It has a very aftringent tafte, and fmells a little like cloves. 


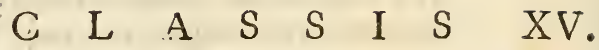

\section{TETRADYNAMIA.}

\section{S I L I C U L O S}

* Silicula integras nec apice emarginata.

DRABA. Silic, valvulis planiufculis. Stylus nullus. SUBULARIA. Silic, valvulis femiovatis. Stylus brevior filicula.

MYAGRUM. Silic, valvulis concavis. Stylus perfiftens.

* : Silicula cinarginata apice.

IBERIS. Petala duo exteriora majora.

COCHLEARIA. Sitic, cordata : valvulis obtufis gibbis.

LEPIDILM. Silic. cordata : valvulis acutè carinatis.

THLASPI. Silic. obcordata: valvulis marginato-carinatis.

\section{S I L I Q U O S Æ.}

* Calyx clcufus foliolis congitudinaliter conniventibus. RAPHANUS, siiiq. articulata. ERYSIMUM. Siliq. tetragona.

CHE,RANTHUS. Eliq. germine utrinq; glandula notato. 


\section{TE T R A D Y A M I A.}

ARABIS. Glandule 4. intra foliola calycina.

Stigma fimplex.

BRASSICA. Glandule 2 intra ftamina breviora;

2 extra ftamina longiora.

TURRITIS. Petala erecta.

* Calyx hians foliolis fuperne diftantibus.

CRAMBE. Siliq. decidua, globofa, ficco-baccata.

Filamenta 4 apice bifurca.

BUNIAS. Siliq. decidua, fubrotunda, muricata. CARDAMINE. Silig. dehifcens: valvulis revolutis.

SINAPIS. Siliq. dehifcens: Cal. horizontaliter patens.

SISYMBRIUM. Siliq. dehifcens : valvulis rectiuf. culis. Cal. patulus. 


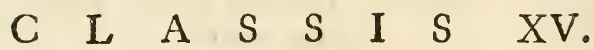 \\ TETRADY N A M I A. \\ S I L I C U L O S A. \\ MYAGRUM. Gen. pl. 796 .}

Silicula ftylo conico terminata; loculo fubmonofpermo.

Jativum* I. MYAGRUM filiculis obovatis pedunculatis polyfpermis. Sp. pl. 894. (Ger. em. 273. f. 3. Moris. bifl. $.3 . t 2 \mathrm{I} . f$. I. ordinis medii ad dextram, E $f$. 2. ordinis inferioris.)

Goid of Pleafure. Anglis.

It is now and then found growing among flax, but was probably at firt imported. $\odot$. VI. VII. The ftalk is a yard high, erect and branched: the leaves are fefile, lanceolate and dented fparingly on the edges. The flowers are yellow, and grow in Ipikes.

It is culivated in Germany for the fake of the feeds, from which an oil is exprefs'd, made ufe of to burn in lamps, \&c.

It is faid that geefe are very fond of the feeds.

$$
\text { SUBUI.ARIA. Gen. pl. } 799 .
$$

Silicula integra, ovata: valvis ovatis, concavis, diffepimento contrariis. Stylus ficula brevior. 
iquatica I. SUBULARIA. Sp. pl. S96. (Moris. hift. S. 8. $t$. 10. f. ultim. Pluk. alm. t. 188. f. 5. malè. Oed. Dan. t. 35. opt. Pet. herb. t. 48 .f. 8. bona) Awl-wort. Anglis.

It grows on the borders of the highland lakes, un- . der the water, in a gravelly or fandy bottom, as in Locb-Tay, in Breadalbane, \&c. Mr. Stuart. $\odot$. VIII.

This plant is about an inch high : the leaves are awl-fhap'd, and grow in a clufter about the root: the ftalk is naked, and produces four or five fmall white fowers, growing alternately on fhort peduncles.

It is very remarkable, that this diminutive plant flowers under the water; whereas moft other aquatic vegetables emerge from that element at the time of flowering. This power of emergence feems however the lefs neceffary in this plant, as the petals are fcarcely ever feen to expand, but connive together, fo as moft probably to defend the impregnating Pollen from the injuries of the water.

\section{DRABA. Gen. pl. 800.}

Silicula integra, ovali-oblonga. valvis planiufculis, diffepimento parallelis. Stylus nullus.

ina 1. DRABA fcapis nudis, fol is fubferratis. Lin. $f y$. nat. 432. sp. pl. 8g6. (Ger. em. p. 624.f. 1. foliis malè exprefis. Pet. levb. t. 48.f. 6, 7. melior. Seguier. veron. p. 329.t. 4. f. 3)

Common 
Common Whitlow-Grafs. Anglis.

On walls and rocks frequent, as on Salifbury-Craigs, \&c. $\odot . I V . V$.

The ftalks are naked, and about two or three inches high : the leaves are elliptical, a little rough and hairy, commonly with one or two dents, and fometimes more on the edges, and lie flat upon the ground in a circle round the root: the petals are white, and deeply Lifid: the Silicula is elliptical and compreffed: the ftyle very fhort.

In rainy weather and in the night the ftalk and flowers hang downwards.

incena 2. DRABA folis caulinis numerofis incanis, filiculis oblongis, obliquis, fubfeffilibus. Lin. fyft. nat. 432. Sp. pl. 897. (Pet. berb. t. 48. f. 3 E 4. Pluk. alm. t. 42. f. I. melior, Oed. Dan. t. 130. opt.)

Wreathen-podded Whitlow Grafs. Anglis.

On dry rocky expofures among the highland mountains not unfrequent. I obferved it in many dry places, firft in the ifland of IJla, upon dry rocky banks near the Danif fort, afterwards in the ille of Skye, upon rocks near Duntulin caftle, and a Creg-e-chnocaen, near Lead-beg, in Aflynt, on the border of Sutberland, growing together with thi Dryas 8 petala, and in many other places. of VI.

The italk is five or fix inches high, hairy, ftiff ereet, moft commonly fingle, but frequentl branched 


\section{TETRADYNAMIA SILICULOSA.}

branched: the leaves are feffile, oval-lanceolate, and fparingly dented on the edges: the flowers are white, and grow in a clufter at the top of the ftalk: the petals are Aightly emarginated; the pods ftand on fhort hairy peduncles, and are twifted in a contrary direction to the fun's diurnal morion.

\section{LEPIDIUM. Gen. pl. Sor.}

Silicisla emarginata, cordata, polyfperma. valvulis carinatis, contrariis.

latifolium I. LEPIDIUM foliis ovato-lanceolatis integris ferratis. sp. pl. 899. (Ger. em. 24I. f. 2. Moris. bift. f. 3. t. 21. f. 1. medii ordinis ad finiftram. Pet. herb. t. 48. f. 10. cum charactere)

Dittander or Pepperwort. Anglis.

Upon the fea coalt, as about the caftle of Weems, in Fife/bire, \&c. 4. VII.

The ftalk is a yard high or more, erect and branched: the leaves are firm, fmooth, and finely ferrated, growing alternately without order, upon the ftalk and branches: the flowers are exceedingly fnall for the fize of the plant, and white, very numerous, and grow in cluftered panicles: the Silicula or feed-veffel is heart-fhap'd, the style fhort, the Stigna globular.

The young leaves are eaten fometimes in faliads; they have a pungent acrid tafte, and are reckon'd antifcorbutic. 
ruderale *2 LEPIDIUM floribus diandris apetalis, foliis radicalibus dentato-pinnatis, ramiferis linearibus integerrimis. Sp. pl. 900. (Pet. berb. t. 50.f. I. Oed. Dan. t. 184 . opt.)

Narrow-leav'd Dittander, or wild Crefs. Anglis. It is now and then found in wafte places upon the fea coaft near wharfs, but veı! probably was imported. ๑. VI.

The ftalk is a foot high, and branched: the Calyces are very fmall, of a pale yellow color, and grow in cluitered frikes, or Racemi : it has generally no petals, and but two Stamina: the Silicula contains only two feeds, one within each valve. The plant has a fœetid fmell and pungent tafte.

\section{THLASPI. Gen. pl. 802 .}

Silicula emarginata, obcordata, polyfperma. valvulis navicularibus, marginato-carinatis.

arvense $\mathbf{I}$.

THLASPI filiculis orbiculatis, foliis oblongis, dentatis glabris. Sp. pl. gor. (Ger. em. 262. f. 1 . Moris. bift. S. 3. t. 15.f. 12. Blackwell t. 68) Treacle Muftard or P'enny-Crefs. Anglis.

In corn fields, but not common, It was objerved upon the borders of fome corn fields near Linton, in Treedale, by the Rev. Dr. Burgefs, of Kirkmichael. $\odot$. VI. VII.

The ftalk is a foot high, angular and branched: the leaves are feffile, and embrace the ftalk at their bafe : the flowers are very fmall and white: 


\section{TETRADYNAMIA SILICULOSA.}

the Silicule are comprefs'd, and remarkably large, being augmented by a circular membranaceous wing, emarginated at the top: each cell contains from one to fix feeds.

The plant fmells of garlick, and in countries where it abounds, is found often to communicate its difagreeable odor to the milk of cows that feed on it. The feeds abound with an oil, ufed formerly for the rheumatifn and fciatica, but at prefent is out of practice.

ampefre $2 \mathrm{~T}$. filiculis fubrotundis, foliis fagittatis dentatis incanis. Sp.pl. go2. (Pet. berb.t. 50.f. 7. bona.)

Mithridate Muftard. Anglis.

In corn fields and dry gravelly foils, but not common. Dr. Parfons.

The ftalk is about a foot high, downy and branched towards the top: the radical leaves are finuated at the bafe, but oval at the end: thofe on the ftalk, as exprefied in the specific difference, but are numerous, feffile, and embrace the ftalk at their bafe : the flowers are fmall and white, and grow in clufters or tufts, which are afterwards lengthened into fpikes : the peduncles are downy, and bear each a fingle flower: the Silicula is llightly downy, oval, and gibbous underneath, having two feeds in each cell.

r. $\beta$. There is a variety of this with fmooth leaves, fcarcely ferrated, and without finuated leaves at 

the root. (Ger. em. p. 262.f. 2. Moris. bift. S. 3. s. t.17.f. 14. Pet.berb.t.50.f.8. Blackwell t. 407)

burfa pafto- THLASPI filiculis obcordatis, foliis radicalibus ris. 3 .

pinnatifidis. Sp.pl. 903. (Ger. em. 276 . f. I. Moris. hift.. 3.t. 20. f. 2. ordinis fuderioris. Pet. berb. t. 49. f. 4,5 E 6. Blackwell. t. 5.)

Shepherd's-l'urfe. Anglis.

Sporran-buachaill. Gaulis.

In corn ficlds, gardens, wafte places, and by wayficies, common. ๑. IV-VI.

The silicula is of the fhape of an inverted triangle: the valves are obtufe, and have no marginal wing : each cell contains about twelve feeds.

ar. $\beta$. There is a fmall variety of this plant, not uncomnion, with radical leaves almolt intire, (vid. Pet. berb. t. 49.f. 7)

It has an infirid tafte, but is recommended by many writers, in hæmorrhagies of all kinds, ufed both internally and externally, in man axd heaft.

\section{COCHLEARIA. Gen. pl. 803.}

Silicula emarginata, turgida, fcabra. valvulis gibbis, obtufis.

officinalis I. COCHLEARIA foliis radicalibus cordato-fubrotundis, caulinis oblongis fubfinuatis. Lin. mantifs. altera. p. 425. Sp.pl. g03. (Ger. em. 4or. $f$. I. Moris. bijt. f. 3.t. 20. f. 1. Pet. berb. t. 49. f. 1. Blackrel. t 227. Oed. Dan. t. 135. opt.)

Cominon 
Common officinal Scurvygrafs. Anglis.

Biolaire. Gaulis.

Upon rocks on the fea coaft, and on the highland motentains abundantly. $\delta . V$.

The radical leaves ftand on long footftalks, are heart-fhap'd at the bafe, but rounded and nightly angular in the circumference, fmooth, fucculent, and of a deep green color: thofe on the ftalk are feffile, oval-lanceolate, embracing the ftalk at the bafe, and have now and then a few large angular dents on the edges: the flowers are white and fweet-fcented: the Silicula is oval, gibbous, and terninated with a fort blunt ftyle: each cell contains four feeds.

It has an acrid, bitter and acid tafte, and is highly recommended for the fcurvy. There are initances of a whole fhip's crew having been cured of that diftemper by it; and as it abounds with acid falts, there can be no doubt but that it is a great refifter of putrefaction. The bett way of taking it is raw in a fallad. It is alfo diuretic, and ufeful in dropfies. The highlanders efteem it as a good ftomachic.

danica 2.

COCHI.EARIA foliis hantato-angulatis, omnibus deltoidibus. Lin. mantifs. altera. p. 425. Sp.pl. 903. (Ger.en. 27 1. f. 5. Moris. bift. S. 3.t. 2 1. f 3. Pet. berb. t. 49.f. 3. Oed. Dan. t. 100. opt.) Danifh Scurvygrafs. Anglis.

Upon the rocks on the fea coaft, intermixed now and 
and then with the preceding, but not common. o. V.

The radical leaves are of ten rounded as in the preceding, but fmaller: the ftalks are weak, and commonly trail upon the ground: the ftalkleaves are baftate, with an angle or dent on each fide near the bafe, and ftand on fhort peduncles.

All authors have defcribed this as a diftinet fpecies from the preceding; we do not therefore prefume to diffent from the general opinion, otherwife we thould be difpofed to term it only a variety, as we have obferved the limits between them infenfibly vanifhing into one another.

granlandica 3 .

C. foliis reniformibus carnofis integerrimis. sp. pl. 904 (Bartb. act. 3.p. 143.t. 144.)

Greenland Scurvygrais. Angiis.

Upon the highland mountains, about Locb-Rannoch, in Perthbire, \&c. and in the Orknies. Mr. Stuart. 8. V. VI.

The radical leaves are very fmall and fucculent, convex on the under fide, and have long threadlike footltalks : thofe on the ftalk are hastate and angular, and have thoit footfalks. The plant is not above two inches high, and from the fpecimens we have feen, we fufpect it to be only a ftarv'd variety of the firft kind.

angiica 4 .

COCHLEARIA foliis omnibus ovato-lanceolatis fubfinuatis. Sp. 1). g०3. (Ger. cm. 401,f. 2. Moris. 


\section{TETRADYNAMIA SILIQUOSA.}

ris. bift. S. 3.t. 20. f. 2. ordinis inferioris. Pet. berb. t. 49.f.2. Oed. Dan. 329. Sed non bona.)

Englifh Sea Scurvygrafs. Anglis.

In the north by the fea fide, and upon the rocks of Inch-Columb. I infert this on Sibbald's authority only. $\hat{\jmath} \cdot \mathrm{V}$. VI.

The leaves are fucculent, and often reddifh : they are all oval-lanceolate, but many of them have often no finufes, but only an angle on each fide, at the bafe: thofe on the ftalk are feffile. Gerard's figure is neareft to nature.

oronopus 5 C. foliis pinnatifidis, caule depreffo. Lin. jy/t. nat. Sp. pl. 904. (Ger. em. 427. f. 2. Biackwell t. 20. Oed. Dan. t. 202.)

Swines Creffes. Anglis.

In moit clayey expos'd places by road-fides, but not common. Sibbald. ๑. VIlI.

The leaves and ftalks are imooth, and lie flat upon the ground all round the root: the flowers grow in Thort axillary tufts, and are white: the filicule are kidney-fhap'd and echinated. Each cell generally contains one feed.

This plant was fome years ago rendered famous, the afhes of it being an ingredient in Mrs. Foonna Stepbens's celebrated medicine for the ftone and gravel; but unfortunately for thofe afflicted with that excruciating complaint, it has not been able to fupport its credit.

It is acrid, and taftes like garden crefs.

IBERIS. 


\section{IBERIS. Gen. pl. 804.}

Cor. irregularis. petalis duobus exterioribus majoribus. Silicula polyfperma, emarginata.

mudicaulis I IBERIS herbacea, foliis finuatis, caule nudo fim. plici. Sp. pl. 907. (Ger. em. 251.f. 4. Moris. bift. f. 3. t. 1 g. f. 5. Oed. Dan. t. 323)

Rock Crefles. Anglis.

On fandy banks and in gravelly foils, but rare. Sibbald. $\odot$. V. VI.

The leaves grow flat upon the earth, all round the root: they are deeply finuated with two or three pair of oval acute lobes, with an odd rounder and larger one at the end: the ftalks arife from the centre of the leaves, unbranched, for the moft part naked, and from two to four inches high: the flowers are white, and grow in tufts at the top of the ftalks : the filicula is nearly heart-fhap'd, and furrounded with a membranaceous wing: each cell generally contains two jeeds.

It is a neat little plant in its growth and appearance, and is diftinguined from the genus of Thlafpi, by having the two exterior petals larger than the other two. 


\section{$S$ I L I Q U O S A.}

CARDAMINE. Gen. pl. 812.

Siliqua elafticè defiliens valvulis revolutis. Stigma integrum. Cal. fubtrians.

\section{- Foliis simplicibus.}

betrea I. CARDAMINE foliis fimplicibus oblongis dentatis. sp.pl. 9r3. (Dillen. Eltbam. t. 6r. f. 7r. Pluk. alm. t. 101.f. 3. Pet. berb. t. 50. f. 3. Sine floribus. Oed. Dan. t. 386. E fig. noft.)

Alpine Ladies-fmock. Anglis.

Upon moift rocks and by the fides of rivulets, near the fummits of the highland mountains in many places, as upon Creg-Chailleach, in Breadalbane, upon a mountain called Baikevall in the inand of Rum abundantly, and upon Ben-na-Caillich, in Strath, in the ine of Skye. 2x. VII.

The ftalks are from three to fix inches high; they recline at the bafe, and increafe by offsets: the radical leaves are fometimes only dented on the edges, but are more frequently deeply finuated with two pair of oval acute lobes, and an odd one at the extremity: the ftalk-leaves are lefs dented, and the uppermoft are elliptical and entire : the flowers are either white or a little ting'd with purple: the valves of the Siliqua burft at the bafe, but do rot coil up like the other fpecies of this genus. 


\section{TETRADYNAMIA SILIQUOSA.}

** Foliis pinnatis.

impatiens 3 C. foliis pinnatis incifis ftipulatis, foribus apetalis. Sp. pl. 914. (Ger. em. 250.f. 7. Moris. bift. S. 3 . t. 4.f. 1. Pet. berb. t. 47.f. 7)

Impatient Ladies-fmock. Anglis.

At the foot of mountains, and in thady places, but rare. Dr. Parfons. $\odot$. V.

The ftalk is from fix to twelve inches high, angular, ftiff, erect, and a little branched : the radical leaves have five pair or more of oval Pinne, which are obtufely lobed: the ftalk-leaves are likewife pinnated, but the Pinna are deeply and acutely dented or lobed, efpecially on the lower edge: the flowers grow in erect fpikes, and the Silique are almoft parallel to the ftalk, and burt with great elafticity when ripe: the petals are whitifh, fmall, and extremely fugacious, but oftentimes it has no petals at all.

birfuta 3. CARDAM:NE foliis pinnatis, foribus tetrandris. Sp.pl. 915. (Barrelier. ic. 455. Pet. berb. 47. f. 4. Scopoli. Flar. Carniol.t. $3^{8}$. Moris. bift. $\int .3 . t$. 4. $f$. I1.)

Hairy Ladies-fmock. Anglis.

In gravelly foils, and often on moift rocks, and by the fides of rivulets. Under Salifunry-Craig. Dr. Parfons. $\odot . V$.

The radica! leaves are numerous, and lie upon the ground in a circle round the root: they have three or four pair of roundifh diftant $P_{i n n e}$, with a larger 
a larger odd one at the end: thefe Pinne ftand on fhort footitalks, are generally a little hairy, and have one or two night dents on the edgres, the extreme one often obfcurely divided a little way down into three lobes: the ftalk-leaves are finilar, but more oval, and narrower, and fometimes lanceolate; the ftalks are generally hairy, angular, from four to eight inches high, branched and feveral from the fame root: the petals are finall and white, about as long again as the calyx: the flowers have of en the two fhorter ftamina deficient, but we frequently find them regular with all fix vifible: the filique burft with an elaftic force. The young leaves are a good fallad.

pratenfis 4. CARDAMINE foliis pinṇatis, foliolis radicalibus fubrotundis, caulinis lanceolatis. Sp. pl. $9^{1} 5$. (Ger. em. 259. f. I, 2. Blackwell t. 227. Moris. bift.. . 3. t. 4.f. 7 . Pet. kerb. t. 47.f. 5)

Common Ladies-fmock, or Cuckow-flower. Anglis. In wet paitures and by the fides of rivulets frequent. 4. V.

The radical leaves have generally about firs pair of Pinnce, nearly heart hap'd, with a few angular dents on the edges: the ftalk is a foot high, erect, round and fiftular: the petals are white, or tinged with purple, with deeper veins, and yellow ungues, and almoft half an inch long: the leaves are very acrid, and the flowers have lately 


\section{TETRADYNAMIA SILIQUOSA.}

lately had fome repute in the cure of epileptic fits.

amara 5. C. foliis pinnatis, axillis ftoloniferis. sp. pl. 9 I 5 . (Nafturtium pyranaicum E'c. Herman. Paradif.pl. 203. Baub. Prodrom. p. 45. fig. ad finifram. Pet. berb. t. $47 \cdot f$. I.)

Bitter Creffes. Anglis.

By the fides of rivulets and in moift places, but not common : by the new well on the water of Leith. Dr. Parfons. 24. V.

The leaves have generally three pair of oval-angular Pinne, with an odd one at the end: the ftalk leaves are of the fame figure, and nearly of the fame fize with the radical ones: the ftalks are angular, and a foot high or more: the petals are quite white, erect, and four times longer than the leaves of the calyx: the antbera are red: the flolones, or young runners from the ale of the leaves, as mentioned in the fpecific difference, are not always to be found: the young leaves are acrid and bitterifh, but do not tafte amifs in fallads.

\section{SISYMBRIUM. Gen. pl. 813.}

Siligua dehifcens valvulis rectiufculis. Calyx patens.

Corclia patens.

* Siliquis declinatis brevibus. 
foliolis fubcordat.s. Sp. pl. 916. (Ger. em. 257. f. 5. Moris. bift. S. 3. t. 4. f. 8. Blackwell t. 260) IVater-creffes. Anglis.

On the brinks of rivulets frequent. 4.8 . VII. The leares have from four to eight pair of fmooth, fucculent and feffile Pinne: the flowers are fmall and white, and grow in hort fpikes or tufts.

The young leaves are well known to furnin an agreeable fallad, and have always been efteem'd as an excelient ancifcorbutic: they are faid likewife to be beneficial in removing obftructions of the vifcera, and in the jaundice.

Jyleftre 2. SISYMBRIUM filiquis declinatis oblongo-ovatis, follis pinnatis, foliolis lanceolatis ferratis. Lin. Jyst. nat. p. 439. sp. pl. 916. (Ger. em. 243. f. 6. Moris. bift. f. 3. t. 6.f. 17. Pet. berb. t. 46.f.5) Vater-Rocket. Anglis.

By water-fides and in wante places, but not common. Dr. Parfons \& Sibucld. 24. VII. VIII.

The ftalk reclines at the bale, but is erect afterwards, fmooth, friated and branched : the leaves have from three to fix pair of Pinne, which are lanceolate, Sharply indented, generally alternate, and fefinle upon a wide rib: the flowers are fmall and yellow: the calyx yellowith: the filique ftand on horizontal peciuncles, and are curv'd a little upwards, fo as to itand almoft parallel to the branches.

S. filiquis 


\section{TETRAD TNAMIA SILIQUOSA.}

ampbibium S. filiquis declinatis oblongo-ovatis, folis pinnatif3 .

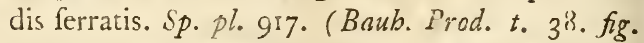
ad dextram. Moris. bift. $.3 \cdot t \cdot 7 \cdot f \cdot 3$. ordinis inferioris. Pet. berb. t. 49.f. g)

Amphibious Rocket, or jagged Water-Radifh. Anglis.

By the fides of ditches, and where water has ftag. nated, but not common. Sibbald. 4. VII.

The leaves of this have four or five pair of oval ferrated Pinne, growing feffile upon a wide foliaceous rib, with an odd one at the end, divided into three lobes: the ftalk is angular, and has many flexures among the flowering branches: the flowers are fnall and yellow : the petals fhorter than the calyx.

Baquaticum There is a variety of this with leaves entire, or only ferrated on the edges. (vid. Baub. Prodrom. t. $3^{3}$. fig. ad. finiftram. Ger. em. 240. f. 2. Moris. bift. $\int .3 . t .7 . f .4$. ordinis inferioris. Pet. herb.t. 49.f. 8.)

Broad-leav'd Water-Radih. Anglis.

This grows with its root under water, in ditches and lakes. 24. VI. VII.

The leaves, which are immeried under water, are pinnated with narrow linear Pinne, but thofe out of the water are lanceolate, and either ferrated on the edges, or a little jagged: the petals are yellow, and longer than the calyx. The whole plant has an acrid tafte. 


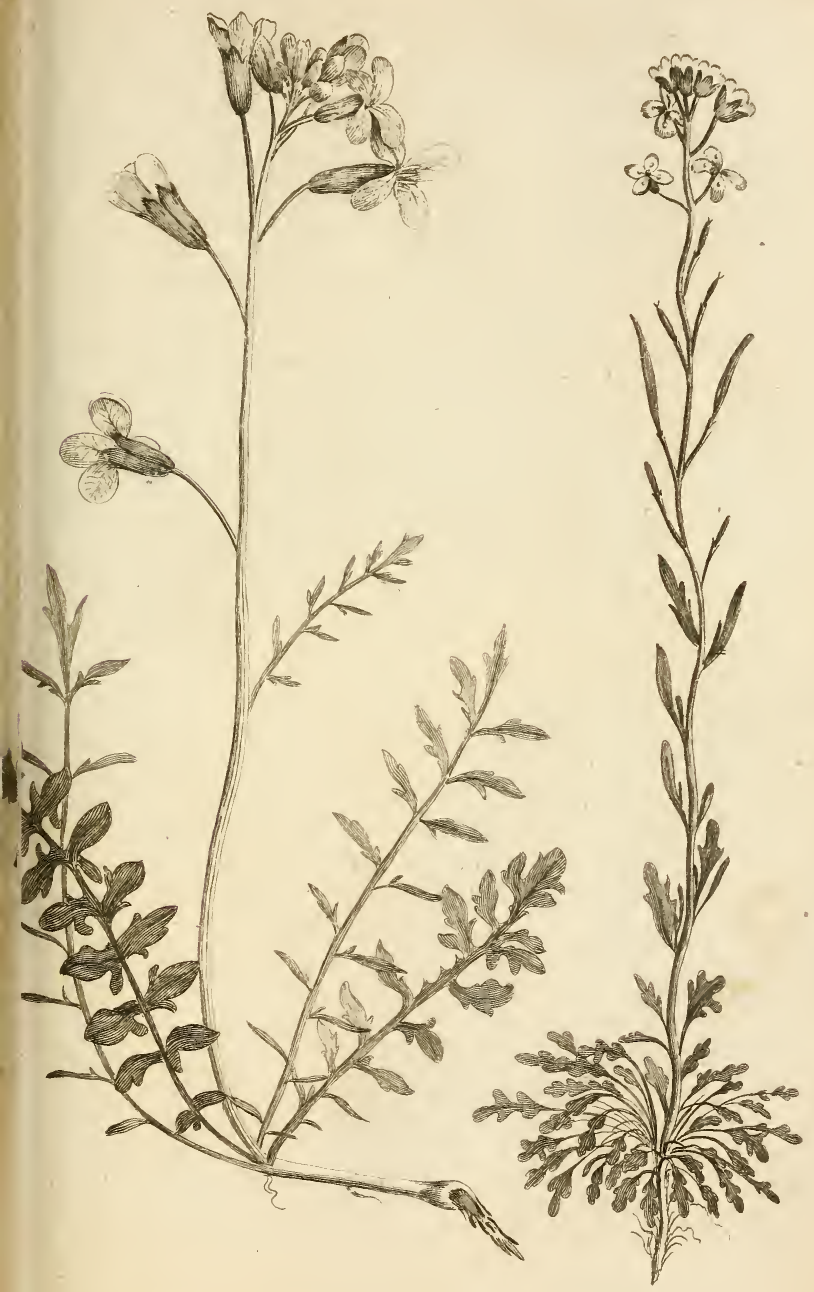

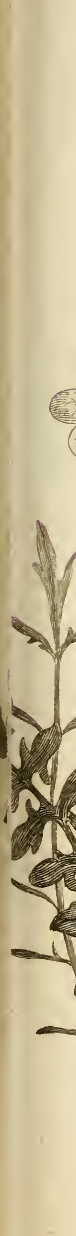

Seriymlimirne Cardumine

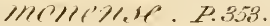

jeetien. P.3.t7. 

** Caule nudo.

monenfe 4. SISYMBRIUM acaule, foliis pinnato-dentatis fubpilofis, fcapis lævibus. Lin. mantifs. altera. $p$. 427. Sp.pl. gis. (Dillen. Eltbam. t. I I I. f. 135 . E' fig. noft.)

Ine of Man Rocket. Anglis.

On the fea fhores in fandy foils in many places, as in the ine of Bute, about a mile to the fouth of Mountflewart, on the weft fide of the inle of Arrain, not far from Druim-an-duin, beyond CarnBaan, and at Lamlajs bay, on the Arran fide abundantly, and in Cantire, on the weftern fide, between Macbrianif bay and Barr, \&c. 4 ? VI. VII.

The radical leaves have five or fix pair of diftant, oval-acute, deeply-indented pinne, growing fome alternate, and fome oppofite to each other, increafing in fize towards the end of the leaf, which is terminated with a larger one, divided a little way down into three lobes, which are indented: thefe leaves have generally a few fcattered hairs upon them, efpecially about their footftalks. Several fmooth, reclining ftalks arife from the centre of the leaves, ten or twelve inches long, which have commonly one leaf towards their bafe, having linear pinne a little indented on their lower edges: the leaves of the calyx are clofed together, and hairy at their fum- 
mits : the petals are yellow, with an entire margin, and twice as long as the colyix.

\section{*⿻: Foliis pinnatis.}

Sopkia 5. SISYMBRIUM petalis calyce minoribus, foliis decompofito pinnatis. Sp.pl. 920. (Ger. em. 1068. f. 1. Pet. kerb. t. $46, f$. 12. Biackivell. t. 440 . Oed. Dan. t. 528 . opt.)

Flix-IVeed. Ainglis.

In wafte places near towns and villages, not uncommon. $\odot$. Ylll.

Whe ttalk is a cubit ligh, erect, and greatly branched: the leaves are a little hairy and foft, doubly pinnated; the pinmula linear: the petals are yellow, very fimall, and not above half the length of the calyx: the leaves of the calyx ftand open : the ftamina are longer than the calyx: the filique are ftrait, parallel to the ftalk, and grow very quick.

A drachn of the feeds of this plant was formerly much ufed in dyfenteries, and to expell worms. but is out of the prefent practice.

\section{ERYSIMUM. Gen. pl. 8is.}

Siliqua columnaris, exactè tetraëdra. Cal. claufus. oficinale I. ERYSIMUM filiquis fcapo adpreffis, foliis runci natis. Sp.pl. 922. (Ger. em. 254.f. I. Moris. bift f. $3 . t .3 . f$. I. ordinis medis Pes. berb. t. 46.f.? Blackivell t. 28)

Iedge-muttard. Anglis. 


\section{TETRADYNAMIA SILIQUOSA.}

In wafte places, and by way-fides not uncommon. $\odot$. VI.

The ftalk is erect, two or three feet high, and branched: the leaves are hairy, and pinnated either with erect, or reverfely hooked finne: their anterior parts deeply cut or jagged, the odd one at the extremity very large and triangular: the upper leaves are trifid, with a pair of pinne under the triangular fegment: the flowers grow in fpikes very fmall and yellow : the filiquee are round, hairy, fubulated at the end, longitudinally ftreaked, ereet, and preffed fo clofe to the branches, as to make them appear naked.

barbarea 2. ERYSIMUM foliis lyratis, extimo fubrotundo. sp. pl. 922. (Ger.em. 243. Moris. bift. f. 3.t. 5 . f. 1 1. Eु 1 2. Pet. berb. t. 46.f. i.)

Winter Creffes, or Rocket. Anglis.

On the banks of ditches and rivulets, but not very common. By the the fide of the water of Leith. Dr. Parfons. 24. V.

The ftalk is a foot and a half high, erect, fmooth, furrow'd, and branched : the leaves are fmooth, of a dark green, and have two or three pair of roundifh alternate or conjugate lobes, connected to a broad foliaceous rib, the extreme lobe being muck the largeft, and either of an oval, or bluntly rhomboiral figure, nightly dented on the edges : the fowers grow in thick fpites, and are yellow: the peduncles are compreffed, and qua-

$$
\text { A a } 2 \text { dranglicur: }
$$


drangular : the flique are fhort, ereet, round, or nightly quadrangular : the feeds are oval, finely dotted, and reticulated.

The young leaves in the fpring are fometimes eaten in fallads, but to molt people they have a bitter unpleafant taite.

alliaria 3. ERYSIMUM foliis cordatis. Sp.pl. 922. (Ger. em. 794. Moris. bift. S. 3.t. $10 \mathrm{f}$. 6. Blackwell t. 372)

Jack-by-the-hedge, or Sauce-alone. Anglis.

In hedges and watte places; under Salifbury craigs, \&cc. Dr. Parfons. 24. V. VI.

The ftalks are a yard high; the branches nearly ereet; the leaves thin. flaccid, and ferrated, fmelling like garlick when bruifed: the flowers are white: the filique hardly quadrangular, but round, with two lateral elevated lines, the middle ones fcarcely prominent: the membrane which runs between the valves is fpongy, and the feeds, which are cylindrical and furrow'd, are imbedded in it.

The leaves were formerly in ufe for feafoning favoury difhes, but are at prefent little regarded, the different kinds of Allium being efteemed much more preferable.

An outward application of them is secommended by Boerbave, and others, in gangreens and cancerous ulcers. 
An infect called by Limnaus Curculio Alliarize breeds in the ftalks.

beiran- E. foliis lanceolatis integerrimis, filiquis patulis. thoides 4 . Lin. Jyft. nat. p. 441. Sp. pl. 923. :Ger. cm. 273. f. 4. Moris. bift. S. 3.t. 5.f. 7. Pet. berb. t. $45 \cdot$ $f .2$ )

Treacle Wormfeed. Anglis.

In corn fields, but not common. Sibbald. ๑. VII. VIII.

The ftalks are a cubit high, erect, and branched: the leaves are feffile, elliptical and acute, nightly dented on the edges, and rough to the touch, being covered with very fhort hairs : the flowers are yellow and fmall, the petals oval: the calyx not gibbous at the bafe: the filique an inch long, erect, and bluntly quadrangular. I have inferted this fpecies as a native on the authority of Sibbald only.

\section{CIEIRANTHUS. Gen.pl. 815.}

Germen utrinque denticulo glanciulato. Cal. claufus, foliolis duobus bafi gibbis. Semine plana.

beiri 1. CHEIRANTHUS foliis lanceolatis acutis glabris, ramis angulatis, caule frufticofo. Lin. fy/t. nct. 44t. Sp. pl. 924. (Ger. cm. 456.f. 1. Pet. bert.

t. 45.f. 3. Moris. hist. S. 3. t. 8. f. :5.)

Wall-flower. Anglis.

Upon old walls and caftles frequent. 4 . Y.

The lowers are yellow and fweet-fcented.

A a 3

ARARIS 


\section{ARABIS. Gen. pl. 818.}

Glandula nectariferæ 4, fingulæ intra calycis foliola, fquamæ inftar reflexæ.

thaliana 1. ARABIS foliis petiolatis lanceolatis integerrimis. Sp. pl. 929. (Moris. bift. .. 3.t. 7. f. 5. Pet. berb. t. 48.f. 1. 2. Thal. barc. 84. t. 7.f. D. Barrelier ic. 269, n. 1. 2. E 270. n. 3. Cranz. p. 41. t. 3.p. 2)

Thale's Crefs, or coded Moufe-ear. Anglis.

Upon walls, dry banks, and gravelly foils not unfrequent. $\odot$. VI.

The ftalks are ten or twelve inches high, erect, branched, and with few leaves on them : the leaves are a little rough and hairy, oval and pointed, often entire, but fometimes nightly indented on the edges, and lie flat upon the ground round the root in a circle: the flowers are fmall and white: the fliqua round, nender, and $p a-$ tent, or diftant from the branches.

\section{TURRITIS. Gen. pl. 819.}

Siliqua longiffima, angulata. Cal. connivens, erectus. Cor. erecta.

birfuta 1. TURRITIS foliis omnibus hifpidis, caulinis amplexicaulibus. Sp.pl. 930. (Baub. Prodrom. 42. ic. ad dextram. Pet. berb. t. 47.f. 12. Moris. bift. f. 3.t. $.3 \cdot f \cdot 5$ )

Hairy Tower-muftard. Anglis. 
Upon dry rocks frequent, as upon the rocks in the king's park at Edinuurgh, \&rc. ô. VI.

The ftalk is rough, a foot high or more, generally unbranched: the leaves are rough, faplefs, oval, nightly ferrated, and fometimes entire, and fpread upon the ground round the root in a circle: the ftalk-leaves are feffile, and embrace the ftalk at their bafe: the petals are of a yellowifh white; the leaves of the calyx the fame, but their fummits tinged with red : the filique are linear, ftrait, convex on both fides, having a longitudinal line in the middile of each valve: the younger filique are dark color'd, and ftand parallel and clofe to the ftalk, but when ripe they hang down : the feeds form little round elevations on the outfide of the valves.

\section{BRASSICA. Gen. pl. 820.}

Cal. erectus, connivens. Sem. globofa. Glandula inter ftamina breviora \& piftillum, inter $8=$ longiora \& caly cem.

uapus I. BRASSICA radice caulefcente fufiformi. $s p . p l$. 931. (Ger. em. 235. f. 2. Moris. bijt. f. 3.t. 2. fig. ultima. Pet. berb. t. 45.f. 9)

Wild Navew. Anglis.

Amongft corn, on ditch banks, and in wafte places. On the rocks behind Edinkurgh caftle. Dr, Parfons. ô. VI.

The ftalk is from a foot to two feet high: the radical leaves are almont fmooth, and divided into deep'y 
deeply pinnated lobes, which lobes are again irregularly indented or finuated on the edges : the ftalk-leaves are fmooth, glaucous, feffile, of a long heart-hap'd figure, nightly denticulated on the edges, and embrace the ftalk at their bafe. The calyx ftands open: the petals are yellow.

There is a variety of this, which has an efculent root, and which is cultivated in many parts of Europe for the fake of an oil which is prefs'd from the feeds.

\section{SINAPIS. Gen. pl. 821 .}

Cal. patens. Cor. ungues recti. Glandula inter ftamina breviora \& piftillum, interque longiora \& Calycem.

arvenfis I. SINAPIS filiquis multangulis torofo-turgidis lævibus roftro ancipiti longioribus. Lin. $\int \pi f$. nat. 444 . Sp.pl. 933. (Ger. em. 233.f. 2. Moris. bijt. S.3. t. 3.f. 7 . Pet. berb.t. 45.f. 12)

Wiid Muftard, or Charlock. Anglis.

In corn fields frequent. $\odot$. V. VI.

The ftalk is roughly hairy, a cubit high, and branched, and is commonly tinged with red between the branches and the root: the leaves are a little rough, and commonly pinnatifid; they have generally one or two pair of lobes, which unite together at their bafe, and a great elliptical odd one at the end, all of them irregularly ferrated: the leaves of the calyx are angular, fmooth, of a yellowin green color, ftanding 


\section{TETRADTNAMIA SILICLOSA.}

open at the top, and two of them gibbous at the bafe : the petals are yellow and vein's : the fili. que are fimooth, o: Aightly hairy, and longer than the roftrum: the feeds are acrid and fufcous, eight or nine in a pod.

The young plants, before they flower, are boiled and caten as greens in feveral parts of England.

alba * 2. S. filiquis hifpidis, roftro obliquo longiffimo enfiformi. Lin. Syt. nat. 445. Sp. pl. 933. (Ger. evn. 244. f. 4. Pet. herb. t. 45. f. 10. Blackwell. t. 29) White Muftard. Ainglis.

It is fometimes found in hedges and wafte places, near towns and villages, but is probably to be confidered only as the outcaft of gardens. $\odot$. VII.

The flowers are yellow, the peduncles ftriated: the filique are white, hairy, fhorter than the roftrum, and have generally three knobs or protuberances over the feeds: the feeds are yellowin, acrid, and three or four in a pod.

The feminal leaves of this plant, with thofe of the Lepidium fativin Lin. afford a well-known fallad in the fpring.

nigra* 3. SINAPIS filiquis glabris tetragonis racemo appreffis. Lin. Jyft. nat.p. 445. Sp. pl. 933. (Ger. em. 244.f. 1. Moris. lift. S. 3.t. 3.f. т. ordinis superioris. Pet. berb. t. 45. f. I. I. Baub. II. p. 855, cum bona icone Eे defcriptione Blackwell t. 446)

Common 


\section{TETRADYNAMIA SILIQUUOSA.}

Common Muftard. Anglis.

A'mharag. Gaulis. Sgeallan, the feeds. Gaulis.

Under hedges and in wafte places, but perhaps only the refufe of gardens. Dr. Parfons \& Sibbald. ๑. VI.

The ftalk is three or four feet high, greatly branched: the branches diftant and open: the leaves pinnatifid, and all, except the radical ones, fnooth: the flowers yellow, the filique fhort: the feeds round and fufcous, extremely acrid, and eight or nine in a pod.

The leaves in the fpring are in fome parts of England boiled and eaten as greens.

The feeds are well known for cul.nary ufes, and are fometimes ufed externally in medicine, where irritation is intended without bliftering.

\section{RAPHANUS. Gen. pl. 822.}

Cal. claufus. Siliqua torofa, fubarticulata, teres. Glondule melliferæ 2 inter ftamina breviora $\&$ piftillum, totidem inter ftamina longiora \& calycem. iapbanifsrum $\mathrm{I}$. RAPHANUS filiquis teretibus articulatis lavibus unilocularibus. (p). pl. 935. (Ger. em.240. f. I. Moris. bift. S. 3. t. 13. f. I, E 2. ordinis medii. pet. heru. t. 4 (j. f. 10)

Jointed podded Charlock. Anglis. In corn fields frequent. $\odot$. VI. VII.

The ftalk is rough, with pellucid spinule, or Tharp hairs: the leaves are pinnatifid, with only one or 
two pair of lobes, and ferrated, generally fmooth but fometimes hairy: the footftalks are commonly hairy : the calyx is hairy : the flowers generally yellow, but fometimes white.

The plant has an acrid tafte, and ftrong alcotine fmell.

\section{BUN!AS. Gen. pl. 823.}

Silicula decidua, tetraedra, angulis inæqualibus acu minatis muricata.

cakile I. BUNIAS filiculis ovatis levibus ancipitibus. $S p$. pl. 936. (Ger. em. 248.f. 5. Moris. hift. I. 3.t.6. f. 20. Pet. berb. t. 46. f. 6)

Sea Rocket. Anglis.

On the fea thores in fandy places not uncommon, as on Leitb fands, at Kirkaldy, on the coaft of Fife, on the weftern fide of Cantire, between Macbrianifis bay and Bars, 3xc. ๑. VI. VII.

The ftalk is about a foot high, often much more, branched from the bafe into wide divaricated branches : the leaves are fmooth, fucculent, pinnatifid, and have a faltifh talte: the flowers grow in fhort fpikes or clufters, of a pale red or Alefl color: the pod is fhort, jointed, and contains two cells, with one or two feeds in each : the ftyle is long and compreffed, which forms afterwards the roftrum of the pod.

CRAMBE. 
CRAMBE. Gen. pl. 825 .

Filamenta 4 longiora apicebifurca, altero antherifero. Bacca ficca, globofa, decidua maritima 1. CRAMBE foliis cauleq; glabris. sp. pl. 937. (Ger. em. 315.f. 15. Moris. bift. J. 3. t. 2. f. 16. Pet. berb. t. 4 \%. f. 12. Oed. Dan. t. 316 . opt. cum. cbaractere.)

Sea Colewort. Anglis.

On the fea coatt in fandy or ftoney foils, but not common. On the Thore by Faft-Caftle, in Berwickßire. Dr. Parfons. 24. VI.

The leaves are bluntly oval, glaucous, fucculent, plaited, and deeply finuated on the edges: the ftem is two feet high, and branched towards the top: the flowers are white, and grow in fhort fpikes or clufters : the fruit is a roundin, pulplefs, green berry, with one cell, containing a fingle feed.

The young leaves cover'd up with fand and blanch'd while growing, are boiled and eaten as a great delicacy. 
MON A DELPHIA.

C I $A$ S $S$ I $S$ XVI.

MONADELPHIA

\section{E C A N D R I A.}

GERANIUM. Monogyna, Caps. 5-cocca, roftrato.

$$
\text { P O L Y A D R I A. }
$$

LAVATERA. Polygyna. Cal. exterior 3-fidus Arilli I-fpermi, verticillati.

MALVA. Polygyna. Cal. exterior 3-phyllus. Arilli I-fpermi, verticillati plures.

ALTHÆA. Polygyna. Cal. exterior 9-fidus. Arilli I-fpermi, verticillati. 


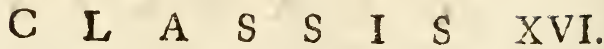

\section{MONADELPHIA}

\section{E C A N D R I A.}

\section{GERANIUR. Gen. pl. $83^{2}$.}

Monogyna. Stigmata 5. Frablus roftratus, 5-coccus.

* Staminibus quinque antberiferis.

cicutarium GERANIUM pedunculis multiforis, floribus penI.

tandris, foliis pinnatis incifis obtufis, caule ranofo. Lin. $\int y / t$. nat, 454. Sp. pl. 95r. ( $\bar{G} \mathrm{cr} . \mathrm{em}$. 945.f. 3. Moris. bift. . . 5. t. 15. f. g. Pet. berb.t. $65 . f .3$. Rivin. pentap. irregul. t. 112. fig. bona.) Hemlocis-leav'd Crane's-bill. Anglis.

In dry paftures, on fanciy fhores, and in wafte places under the walls of towns frequent. $\odot$. V.VIII.

The leaves generaily fpread flat upon the ground, are fometimes hairy and fometimes fmooth, and confift of a long feries of nearly equal pimna, which are fefile and tharply pinnatifid : the peduncles arife from the ale of the leaves: the fripule are oval, filmy, and white: the calyx a little hairy and open: the petals (which are always five in this genus) elliptical, red, and a little unequal, the two upper ones being fome- 
what fhorter than the three lower ones, and placed at a fmall diftance from them. The filaments are commonly ten, but five only are fertile, or bear antbcre.

We obferved a variety of it with white fowers on the fea banks near Weems, in Fifefbire.

pyrenaicum 2.

GERANIUM pedunculis bifloris, foliis inferioribus quinque-partito-multifidis rotundatis, fuperioribus trilobis, caule erecto. Lin. mantifs altera. p. 257. Geran. perenne. Huds. Flor. Anglica. 265. (Girard. Provincial. 434. t. 16.f.2)

Perennial Dovesfoot Crane's-bill. Anglis.

In mountainous paftures and walte places near $E$ din burgh, but not common. 24. Dr. Parjons.

The ftalk is twelve or eighteen inches high, hairy, ereet, and diffufely branched: the leaves are hairy, the fegments a little obtufe, having a red line on the margin, and unequally cut or dented: the leaves of the calyx have each a red glandule at the apex: the petals are twice the length of the calyx, emarginated, and of a blueinh purple color: the five outer flamina are deftitute of anthere, and fhorter than the others.

* Staminibus decem antberiferis. Pedunculis bifloris. 4.

Jyliaticum 3 .
GERANIUM pedunculis bifloris, foliis fubpeltatis quinquelobis incifo-ferratis, caule erecto, petalis emarginatis. 
emarginatis. Sp. pl. 954. (Ger. em. 942. f. 2. Oed. Dan.t. 124. opt.)

Mountain Crane's-bill. Anglis.

By the fides of rivers in rocky and hady places frequent, hoth in the highlands and lowlands. 4. VI. VII.

The ftalk is ereet, from twelve to eighteen inches high : the leaves are hairy and wrinkled : the panicle dichotomous : the calyces hairy and bearded: the petals large, purple, ftreaked with deeper veins, and heart-rhap'd.

The flowers are ufed by the Icelanders to dye a violet color.

pratense 4. G. pedunculis b:floris, foliis fubpeltatis, multipartitis, rugofis, acutis; petalis integris. Syft. nat. 455. Sp. pl. 954. (Ger. em. 942. f. I. Moris. bift. f. 5. t. 15. f. 14. Pet. herb. t. 65.f. 7. Hort. Aickftett. vern. ord. I. t. 8)

Crowfoot Crane's-bill. Anglis.

In paftures and thickets not uncommon, as at $\mathcal{T}_{\text {ay- }}$ rizoutb hermitage, and about the cafcades at $M_{0}$. $n e \int s$, and in the paftures of Loch-Rannoch, and many other places. 24. VII.

The ftalk is a cubit high, ftriated, gouty at the joints, and branched: the leaves are hairy, and deeply divided into five, and fumetimes feven lobes, which lobes are laciniated, and thefe lacinice are again Tharply indented: the colyces are hairy, 


\section{MONADELPHIA DECANDRIA.}

hairy and terminated with a beard: the Petcls are blue, ftreaked with red veins, not emarginated, but obtufe and entire at the top: the fyle is longer than the ftamina.

It is reckon'd a vulnerary, but is out of ufe.

\section{* Staminibus io antheriferis. \\ Pedunculis bifloris. $\odot$.}

obertianuin 5 .

GERANIUM pedunculis bifloris, calicibus pilofis decemangulatis. Sp. pl. 955. (Ger en. 939. Moris. bift. S. 5. t. 15. f. I1. Pet. berb. t. 65.f.5. Blackwell t. 480)

Herb Robert. Anglis.

Upon rocks and ftoney places. $\hat{\sigma}$. V. VI.

The whole plant is often of a reddith color, cover' $\dot{\alpha}$ with white hairs, and fmells like a goat: the leaves are doubly pinnated, the exterior pinne running together at the bafe, and the fegments terminated with a red jpinula, or tharp hair: the calyx is hairy, bearded, and ftreaked with ten prominent lines, the firit and third leaf having three of thefe lines, the fecond and fifth one unly, and the fourth tivo the petals are roundifh and entire at the top, of a red color, with white veins. It varies fometimes with a white flower, but very rarely.

It is reckoned aftringent and vulnerary, but is feldom ufed in medicine.

It is faid that the fmell of the bruifed herb will drive away bugs.

$\mathrm{B} b$ 
An infufion of it is given by the Swedi/h herdfinen to cure cattle that make bloody water.

lucidsm 6. GERANIUM pedunculis biforis, calycibus pyramidatis, angulatis, elevato-rugofis, foliis quinquelobis rotundatis. $S p$. pl. 955. (Moris bift. . 5.t. 1 5. f. 6. Pet. berb. t. 64. f. 12. Column. Ecpbras. I. p. I38. ic. 137. OEd. Dan.t. 218. opt.) Shining Crane's-bill. Anglis.

Upon rocks in thady places, as on the fouth-weft fide of the rocks under Artbur's feat at Edinburgh, ixc. ○. VI. ViI.

The root and radical leaves are red, and oftentimes the whole plant: the leaves are commonly fmooth and Mining, divided into five obtufe lobes, each of which has three or five unequal ferratures: The ftalks are near a foot high, and diffufely branched: the calyces are ovally conical, angular, and tranfverly wrinkled: the petals red and emarginated.

molle 7 .

G. pedunculis biforis, foliifque floralibus alternis petalis bificis, calycibus muticis, caule erectiuf culo. Lin. Syst. nat. 455. sp. pl. 955. (Ger. em 938. Pet. herb. t. 64. f. I. Vaill. Paris. t. 15.f. 3 . bona.)

Common Dovesfoot Crane's-bill. Anglis.

In partures and by way-fides frequent. $\odot$.VI.

The whole plant is hairy and foft to the touch : th leaves in circumference are roundifh or kidney Thap's 


\section{MONADELPHIA DECANDRIA.}

thap'd, divided half way down to the rib into five or feven lobes, which are obtufely trifid: the calyces are ciliated, and have a very thort beard: the petals are heart-hap'd, deeply emarginated, and of a red or purple color: the peduncles hang downwards: the fipulce are ferruginous, awl-fhap'd and bifid, two at the bafe of each leaf.

difjectum 8.

GERANIUM pedunculis bifloris, foliis quinquepartito-trifidis, petalis emarginatis, longitudine calycis, arillis villofis. St.pl. 956. (Pet.berb. b. 64.f. 7. Vaill. Paris. t. $15 . f .2$. bona.)

Jagged-leav'd Dovesfoot Crane's-bill. Ang'is.

In meadows, but not common. By the bridge in the meadows at Edinburgh. Dr. Parfons. ๑. VI. VII.

The ftalk is a foot high, ereet, branched, gouty, and red at the joints: the leaves are hard and fi $m$, divided deeply into five lobes, which are again cut into three or four acutelocinis: the ftipula are red: the leaves of the calyx are hairy, and terminated each with a red obtufe beard: the petals are flefh.color'd: the pifil hairy, the antbera blue: the arillus, or exterior coat of the feed hairy.

columbinum G. pedunculis bifloris folio longioribus, foliis quin9. quepartito-multifidis, laciniis acutis, arillis glaLris, calycilus ariftatis. $S p \cdot p l .95^{6}$. (Moris. bift. $\mathrm{B} b 2$ 
f. 5. t. 15.f. 3. Pet. berb. t. 64. f. 8. Vaillant. poris. t. is. $f \cdot 4$. bona.)

Long-ftalked Dovesfoot Crane's-bill. Anglis.

In dry mountainous places, but not common. I obferved it on a dry rocky place in the road going from Glafgose to Dumbarton. ๑. VI. VII.

The ftalk is decumbent, ten or twelve inches long, branched, and knotty at the joints: the leaves are firm and nightly hairy underneath : the nargins of the lacinice reflex'd: the ftipule are linear and reddifn: the peduncles three inches long: the calyx large, almoft fmooth, the leaves of it concave, owing to their margins being reflexed, and terminated with a long beard, having a red glandule at the apex: the flowers are purple, the petals emarginated with a prominent dent betweensthe coat of the feed fmooth.

\section{**** Staminibus 10 antheriferis. Pedunculis unifioris.}

Sanjuinesm GERANIUM pedunculis unifloris, foliis quinque10. partitis trifidis orbiculatis. Sp. pl. 958. (Ger. em. 945. $f$. 2.)

Bloody Crane's-bill. Anglis.

Upon rocks and fandy grounds near the fea in many places, as about Arthur's feat at Edinburgh, and in the ifland of Fona abundantly, \&c, 24. VII.

The root is thick and woody : the ftalk and leaves are a little hairy, the firft a foot or more high: the 


\section{MONADELPHIA DECANDRIA.}

the peduncle is long, and bears a fingle, large and Specious purple flower: the petals are roundifh at the point, and widely expanded: the caly:x is hairy, and bearded with herbaceous arifter.

The plant is reckoned aftringent and vulnerary, but is rarely ufed.

It is often introduced into gardens as an ornament.

$$
\begin{aligned}
& \text { P O L Y A N D R I A. } \\
& \text { ALTH死A. Gen. pl. } 839 .
\end{aligned}
$$

Cal. duplex; exterior 9 -fidus. Arili plurimi, monofpermi.

ficinalis 1* ALTHÆA foliis fimplicibus tomentofis. ip. pl. 966. (Ger. em. 933. f. 1. Moris. bift. .. 5. t. Ig. f. 12. Blackwell t. 290. (Ed. Dan. t. 530.)

Marhmallow. Angiis.

It is now and then found in wafte places near houfes, but is probably only the outcalt of gardens. 2 . VIII.

The ftalk is erect, five feet high, and but little branched: the leaves are of a heart-Phap'd lanceolate figure, divided very obfcurely into three lobes, ferrated on the edges, and foft as velvet: the flowers arife from the alce of the leaves, alnoft feffle, and are whition or flefh-color'd: the petals are five, and emarginated.

The root and leaves have a mucilaginous quality, and are often ufed in a fyrup or decoction as a $\mathrm{B}$ b 3 balfamic 
balfamic pectoral for coughs and hoarfenefles. It is found alfo to be ferviceable in nephritic complaints, and the ftrangury ; and is ufed in cataplafns and fomentations againft fwellings. 'The root will turn water to a jelly.

\section{LAVATERA. Gen. pl. 842 .}

Cal. duplex, exterior trifidus. Arilii plurimi, mo. nofpermi.

arborea 1. LAVATERA caule arboreo, foliis fepremangularibus tomentofis plicatis, pedunculis confertis unifloris axillaribus. $\Sigma p$. pl. 972 . (Figuram fidendam non invenio.)

Sea Tree-mallow. Anglis.

On rockis upon the fea coaft, as in Tincb-Garvey and Mykric-Inch, in the Firtb of Forth, and in Bafje ifiand. Sibbald. of: VII.

The ftalk is erect, branched, and three or four feet high, firm and ftrong: the flowers are red, ftreak'd with veins of a deeper color. It is often brought into gardens for ornamert.

\section{MALVA. Gen. pl. 841 .}

Cal. duplex, exterior 3-phyllus. Arilli plurini, monolpermi.

rotundifolia I.
MALVA caule proftrato, foliis cordato orbiculatis obfoletè quinquelobatis, pedunculis fructiferis declinatis. Lin. Jy/. nat. 460. sp. pl. 96g. (Ger. em. 930.f. 2. Moris. liff. S. 5. t. 17.f. 7.)

Dwarf- 


\section{MONADELPHIA POLYANDRIA.}

Dwarf-mallow. Angris.

In waite places and by way-fides near towns and villages. $\odot$. VII. VIII.

Befides what is imply'd in the fpecific difference, the leaves are crenated: the peduncles are about an inch long, bearing generally a fingle flower, but fometimes two or three: the petals are commonly white, ftreaked with red veins: the fegments of the interior calyx are denticulated: the leaves of the exterior are narrow and linear: the ftyles are thirteen or fourteen, hairy on one fide.

ylveftris 2. M. caule erecto herbaceo, foliis feptemilobatis acutis, pedunculis petiolifque pilofis. Sp. $p l .969$. (Ger. em. 930.f. I. Moris. bift. f. v. t. 17.f. 8. Blackwell t. 22)

Common Mallow. Anglis. In wafte places and by way-fides. $\delta$. VI-VIII. The ftalk is a yard high, or more, and branched: the leaves are ferrated: the flowers grow in clufters from the ale of the leaves, one on a peduncle: the petals are widely expanded, and deeply emarginated, of a purple color, with deeper veins: the calyces are hairy: the capfules from ten to fifteen.

The whole plant is mucilaginous and emoliient; a decoction of it, or an infufion of the flowers is recommended as a pectoral, and good for the ftone and gravel, and other complaints in the urinary paffages; it is likewife given in clyfters in the 
the dyfentery, tenefnus, and gonorrhæa, and is ufed by way of cataplafm in inflammations: the ancients fed upon a fpecies of mallow, tho' probably not this kind, as we learn from Horace:

- Me pafcunt olivæ,

Me Cichorea, levefq; malva. Lib. I. Ode. xxx.

mofcbata 3. MALVA caule erecto, foliis radicalibus reniformibus incifis; caulinis quinquepartitis pinnato-multifid.s. Lin. $\int y /$. nat. 461. Sp. pl. 971 . (Column. ecph. I. p. 14s. t. 147. Moris. bift. S. 5. t. 18.f. 4.)

Jagged-leav'd Mallow, or Munk-mallow. Anglis.

In neadows and paftures, but not very common. We obferved it about Duplin, near Perth, \&c. o. VIII.

The ftalk is a cubit high, branched and hairy; the harrs eret, and arifing each fingle one from a prominent dot or tubercle: the radical leaves are obicurely divided into five lobes, and ferrated on the edges : thofe on the ftalk have their lobes divided to the bafe, which lobes are pinnatifid, and thefe pimule again tharply ferrated: the flowers are flen-color'd, have a muky fmell, and grow in clufters at the tops of the branches, one on a peduncie: the capfules are hairy, and about fifteen in a circle round the receptacle. 
D I A

\section{L A S S I S XVII.}

D I A D E L P H I A. H E X A N D R I A.

FUMARIA. Cal. 2-phyllus. Cor. ringens, bafi gibbofa nectarifera. Filamenta antheris 3 .

$$
\text { O C T A D R I A. }
$$

POLYGALA. Cai. 2-lacinix alieformes. Cor. vexillum cylindricum. Stamina connexa. Caps, obcordata, 2-locularis.

\section{DE C A N D I A.}

* Stamina omnia connexa.

SPARTIUM. Filamente adhærentia germini. Stig. ma adnatun, villofum.

GENISTA. Piftillum deprimens carinam. Stigma involutum.

ANTHYLLIS. Cal. turgidus, includens filiquam. ULEX. Cal. 2-phyllus. Legum. vix calyce longius. ONONIS. Legumen rhombeum, feffile. Vexillum ftriatum.

* Stigma pubefcens (nec priorum notæ)

OROBUS. Stylus linearis, teretiufculus, fupra villofus. 
D I A D E I P. H I A.

LATHYRUS, Stylus fupra planus villofufque.

VICIA. Stylus fub ftigmate barbatus.

** Legumen fubbiloculare (nec priorum)

ASTRAGALUS. Legumen biloculare rotundatum.

***** Legumina monosperma (nec priorum)

TRIFOLIUM. Legum. vix calyce longius, I.s. 2 -fpermum, Flores capitati.

\section{*\$*** Legunen fuborticulctum.}

ORNITHOPUS. Legumen articulatum, arcuatum. MEDICAGO. Legumen fpirale, membranaceo-compreflum. Piftilium carinam deflectens.

***;** Legumen uniloculare polyspermum (nec priorum) ERVUM. Cal quinquepartitus, fubæqualis, longitudine ferè Corollæ. Stigna capitatum, imberbe. LOTUS. Legumen teres, faretum feminibus cylin. dricis.

\section{Objerv.}

PINNAT Fi abfqie impari. OROBUS, LATHY. RUS, VICIA, ERVUM.

PINNATE cum impari. ASTRAGALUS, ORNITHOPUS perpufillus.

IRIFOLIATE. TRIFOLIUM, LOTUS, MEDICAGO, GENISTA, ONONIS.

UMBLLLATE. LOTUS, ORNTHOPUS. 


\section{$C$ L $A S S$ I S XVII.}

D I A D E L P H I A. H E X A N D I A.

FUMARIA. Gen. pl. 849 .

Cal. diphyllus. Cor, ringens. Filamenta 2, membranacea, fingula antheris 3 .

officinalis I. FUMARIA pericarpiis monofpermis racemofis, caule diffufo. sp.pl. 984. (Ger. cir. 1088. f. I. Rivin. tetrap. irreg. t. I. Miller. ic. pl. 136. f. 2. Blackwell t. 237)

Common, or officinal Fumitory. Anglis. In corn fields and gardens frequent. $\odot . V$. VI.

The ftalks are eight or nine inches high, numerous, weak, angular, fucculent, intricately branch'd, and arife from a fibrous root: the leaves are glaucous, and doubly pinnated, the pinnule divided into three lobes, which are bifid and trifid : the flowers are purple, and grow in thick fpikes: the caly $x$ is dentated: the end of the ala, and and fides of the vexillum are of a dark purple, but the middle of the vexillum in the fore part is greenith: at the bafe is a thick nectariferous fcale, ending in a blunt curved fpur: the pericarpium is globular. 
The plant has a bitter tafte, and is ufed in medi. cine as a great purifier' of the blood, in the cachexy, hypochondria, and ficurvy. The great Bcerbave frequently prefcribed it in the black jaundice and bilious cholicks: a drachm of the extract or infpiffated juice is the common dofe.

caspreolata 2 F. pericarpiis monofpermis racemofis, foliis fcandentibus fubcirrhofis. ip. pl. $99_{5}^{5}$. (Fig. non. invenio.)

Ramping Fumitory. Anglis.

About Redball, four miles from Edinburgh, and amongt the rocks by the fea fide going from Corry to Brodic, in the ine of Arran. $\odot$. VII.

Sone authors have confidered this only as a variety of the former fpecies, and indeed it differs but littie from it. It is generally a much taller plant, and has larger flowers, but the principal diftinction confints in the foutfalks of the partial leaves, which are curved, and act the part of tendrils by clafping about, and cimbing up the neighboring plants.

dootulate FUMARIA filiquis linearibus, foliis cirrhiferis. Sp. fl. o8 5. (Ger. em. 1088. f. 2. Moris. bift.\% 3.t. 12.f.3. OEd. Dan t. 340. optima.)

Climbing yellow Fumitory. Anglis.

Upon rocks and ftoney places, and fomctimes upon thatch'd houfes. In the quarries at Inner-Keith, Ec. $\odot$. VII. VIII. 
The ftalks are weak, and unable to fupport themfelves withour climbing: the leaves are pinnated, the pinne grow alternate upon footfalks, and are compounded of two, three, four or five elliptical acute foliola: the compound leaf is terminated with a dichotomous tendril : the flowers are ftraw-color'd, and grow in fhort fpikes: the filique are thort and linear, and contain about three feeds.

\section{OCT A N D R A. \\ POLYGALA. Gen. pl. $35 \mathrm{x}$.}

Cal. 5-phyllus, foliolis duobus alxformibus, coloratis. Legumen obcordatum, biloculare.

vulgaris I. POLYGALA fioribus criftatis racemofis, caulibus herbaceis fimplicibus procumbentibus, foliis lineari-lanceolatis. sp. pl. o\$6. (Ger. em. 563. f. 2, 3, 4, E 564. f. 5. Vaill. paris. t. 32. f. I. bon. Oed. Dan. t. 516 . opt.)

Milkwort. Anglis.

In heaths and dry paftures very common. $2 . \mathrm{VI}$. The ftalks are about five or fix inches long, feveral arifing from the fame root: the leaves are firm, fmooth, entire, and grow alternate upon the ftalks, which are terminated with fpikes of fowers moft commonly blue, but often red, $\mathrm{o}^{\circ}$ white : the calyx confifts of five leaves, three of which are fmall and green, two below and one above the Corolia; the other swo intermediate 
ones are large, oval, flat, color'd, vein'd, and refemble petals, which at length turn greenifh, and remain a defence to the feed-veffel: the $\mathrm{Co}_{0}$ rolla confifts of three petals, folded together, and forming a tube: the carina is terminated with a kind of heart-hap'd concave appendage, fringed at the extremity.

It has a bitter tafte, and has been found to poffers much the fame virtues as the POLYGALA Senega, from America. It purges without danger. It is allo emetic and diuretic, and fornetimes acts in the three different ways together. A fpoonful of the decoction, made by boiling an ounce of the herb in a pint of water till half is cxhaled, has been found ferviceable in pleurifies and fevers, by promoting a diaphorefis and expectoration; and three fponnfuls of the fame taken once an hour, has proved beneficial in the dropfy and anafarca. It has alfo been found fuccefortul in pthificky complaints.

\section{DECA N D R A. \\ SPARTIUM. Gen. pl. 858 .}

Stigma longitudinale, fupra villofum. Filamenta germini adhærentia. Cal. deorfum productus.

Scopariums I

SPAR TIUM foliis ternatis folitariifque, ramis inermibus angulatis. Sp. pl. 996. (Ger. em. 1311. f. 1. Rivin. t. 65. Blackwell t. 144. Oed. Dan.t. 3'3. $o p t$.)

Common 
DIADELPHIA DECANDRIA.

Common Broom. Anglis.

Bealaidh. Gculis.

In dry foils not unfrequent. In Rofin woods. Dr. Parjons. h. VI. VII.

The lower leaves of this Mrub are hairy and ternate, the upper ones fingle: the Howers are ytllow, and grow in thin fpikes, intermixed with leaves, one on a peduncle.

It has a bitter tafte and diuretic quality. A lixivium made of the afhes, or a decoction of the plant, ftands recommended for the dropfy. The flowers and feeds, from two drachms to balf an ounce, are a ftrong vomit. Its œeconomical ufes are various.

The flower-buds are in fome countries pickled and eaten as capers, and the feeds have been made a bad fubftitute for coffee. 'The twigs and branches are ufed for making of brooms, and for tanning of leather, in which intention they are not inferior to oak-bark: they are alfo ufed inftead or thatch to cover houfes: the old wood furnifnes the cabinet-maker with moft beautiful materials for vaneering: the tender branches are in fome places mixed with hops for brewing; and the macerated bark is found capable of being manufactured into cloth.

GENISTA. Gen. pl. 859 .

Cai. bilabiatus, 2-3. Vexillum oblongum, a piftillo 1taminibufque deorfum reflexum.

* Tncrmes. 
* Inermes.

tiwitorio 1. GENISTA foliis lanceolatis glabris, ramis ftriatis teretibus erectis. Sp. pl. 998. (Ger. em. 1316. f. I. Rivin. t. 67. Oed. Dan. t. 526. opt.)

Dyer's-weed, or Wood-waxen. Anglis.

On dry gravelly hilis, and by the fides of rivers in the low-lands frequent. $h$. VII.

From the fame root arife many angular, tough ftalks, a cubit high, which are terminated with fhort fpikes or clufters of yellow feffile papilionaceous flowers: the leaves are numerous on the ftalks, elliptical, acute, feffile and fmooth, except the edges and nerve on the under fide, which are often downy.

This plant is well known to dye yarn and cloth with a bright yellow color.

A falt prepared from the athes of it is by fome much recommended in the dropfy.

** spinose.

anglica 2. G. fpinis fimplicibus, ramis foriferis inermibus, foliis lanceolatis. sp. pl. 999. (Ger. em. i $320 . f$. 4.)

Needle-Furze, or Petty-Whin. Anglis.

In heathy and moorifh grounds, as a mile above Dunkeld, growing amongt the arbutus woa urf, and pyrola rotundifolia, and in many other places not unfrequent." $h$. VI. 
The ftalks generally recline on the ground, and are tough and woody : the leaves are finall, ellintical and acute: the flowers yellow, and grow in thin fpikes.

\section{ULEX. Gen. pl. 88ז.}

Cal. 2-phyllus. Legumen vix calyce longius.

europerus I. ULEX foliis villofis acuris, spinis , fparfis. Sp. $1, l$. 1045. (Ger. cm. 13!9.f. 1)

Furze, Whins, or Gorfe. Anglis.

In the low lands frequent, but not fo common in the highlands.

The leaves are narrow and lanceolate, and grow fingly under the fpines : the branches are ftrater, the fpines compound, the flowers yellow.

tar 3 . There is a variety of this much more dwarfin, and fmaller in all its parts. (v. Ger. em. 1321.f. 6) In Eniland fences are frequently mate of this plant by fowing the feeds.

Horfes, fheep, and other cattle are very fond of it, but as the fpines annoy them, and prevent their feeding on it, the hurbandmen in many parts of $W$ ales bruife the tender branches, or grind them in mills for that purpofe, by which means they become an excellent fodder.

$$
\text { O \ONIS. Gen. p?. } 863 \text {. }
$$

Cal, 5-partitus; lnciniis linearibus. Texillum ftriatum. Legumen turgidum, feflle. Fitamonto connata abfque fifura.

$$
\text { CC ONONIS }
$$


arven/ss 1. ONONIS floribus racemofis geminatis, foliis ter. natis, fuperioribus folitariis, ramis inernibus fubvillofis. Lin. lyst. nat. 478. Sp. pl. 1006. (Ger') $\mathrm{cm} .1322 . f .3$ ?)

Rettharrow or Cammock. Anglis.

In barren paftures, but not very common. On the fea coaft near Leith. Dr. Parfons. 24. VII. VIII, The ftalks recline towards the ground, are tough and branched, and have a red hairy bark : the leaves are ferrated, vifcous and fotid, their footftalks broad and foliaceous: the flowers are red, and grow from the ale of the branches, each on its own fhort footftalk, either fingle or in pairs, but towards the fummits of the branches they form a foliaceous fpike: the Calyx is hairy, incurv'd, and tubular, the upper fegments nearly ftrait, and feparated by a kind of fiffure : the lower one is longer than the reft : the pod is fhort, rhomboidal, and contains about three kidney-hhap'd feeds.

Jpinofa. Po As this plant grows old the branches are all terminated with a tharp woody fine, which many authors have defcribed as a diftinct fpecies. (vid. Ger. em. 1322. f. 1. Rivin. t. 69. Blackwell t. 302.)

Prickly Retharrow, or Cammock. Anglis. It grows upon the fides of the hills by DidiftonLoch, near Edinburgh, \&zc. Dr. Parfons. 24. VII. VIII.

As this plant abounds in the Holy-Land, Hafelquift 
(in his voyage thither, p. 289) fuppofes, with great probability, that this is the thorn mentioned in the fipture which the ground produced after the curfe. (Gen. ch. 3. v. 18.)

The root and bark have a diuretic quality, and are recommended in the gravel, and in fuppreffions of urine, both for man and beaft.

repens 2. ONONIS caulibus diffufis, ramis erectic, foliis fuperioribus folitariis, ftipulis ovatis. Sp. pl. 1006. (Dillen. Eitbam.t. 25.f. 28.)

Creeping Reftharrow. Anglis.

Upon the fea fhore in fandy foils frequent. 2\%. VII. VIII.

The ftalks of this kind lie flat upon the ground, and the flowers are produced fingle from the ale of the branches: in other refpects it differs not from the preceding, and we are inclin'd to believe it only a variety, as we have fometimes obferv'd it, like that, to acquire fpines.

\section{ANTHYLLIS. Gen. pl. 864.}

Cal. ventricofus. Legumen fubrotundum calyce tectum.

ulneraria 1.

ANTHYLLIS herbacea, foliis pinnatis inæqualibus, capitulo duplicato. $s p . p l$. IOI2. (Ger. cm. 1240. f. 1. Rivin. t. 18. \& varietas ejus flore coccineo Dillen. Elth. t. $320 . f . f .413$.

Kidney-Vetch, or Lady's-Finger. Anglis.

In dry paftures not unfrequent, as upon the hills in the king's park at Edinburgh's, \&c. 4. VII.

C $\mathrm{C} 2$ 
Many unbranched ftalks arife from the fame root, 10 or 12 inches high : the leaves are downy; the radical ones for the moft part fimple, and either lanceolate or obtufely elliptical, with long footftalks, to which a fpurious pinna is fometimes annexed: the ftalk-leaves are compound, having three or four pairs of oval-lanceolate pinna, the imalleft at the bafe of the rib, with an odd obtufe oval and larger one at the end: the upper leaves have five or fix pair of pinna, which are all equal : the two Bractea, or floral leaves, are. either digitate or trifid, their fegments lanceolate: the flowers are commonly yellow, but are fometimes feen red, or whitih ; they grow in a double head or clufter at the top of the ftalks: the calyx is hairy and inflated : the carina or keel of the flower is reddifh at the apex: the sinthera ftand on fine pedicles: the pod is likewife fupported by a fhort pedicle, and contains one feed. The plant is fuppofed to have an aftringent quality: and is fcarcely ever eaten by catcle.

\section{OROBUS. Gen.pl. $87 \mathrm{I}$.}

Stylus linearis. Cal. bafi obtufus, laciniis fuperiori. bus profundioribus, brevioribus.

tukerofus $\mathrm{x}$. OROBUS foliis pinnatis lanceolatis, ftipulis femi. fagittatis integerimis, caule fimplici. Sp. pl 1028. (Ger. em. 1237. f. 2. Moris. bift. S. $2 . t$

21. f. 3: ordinis medii ad dextram. Thal. barc. 7

t. 1. Rivin. t. 59. Sibbald. Scot. illuft. p. Ir. f. 1 Loes. Pruf: 138.t. 37. bona.) 
Wood-Peafe, or Heath-Peafe. Anglis.

\section{Corr, Cor-meille. Goulis.}

In mountainous paftures and woods very frequent, both in the highlands and lowlands. 21. VI.

The root confifts of tough fibres, fwelling here and there into irregular tubercles, each of which produces a ftalk about a foot high, having foliaceous or winged angles, and branched only a little at the top: the leaves grow alternate upon the ftalk, about three or four in number, each confifting of two or three pair of fmooth pinne, the lowermort oval, the uppermort acutely elliptical, hav. ing no odd one at the end, but the rib to which they are annexed is terminated with a point or beard : the flowers are of a purple color, verging to blue, and grow from two to five in a thin fpike, upon naked peduncles, arifing from the ale of the leaves near the top of the ftalk: the $V$ exillum, or upper petal of the flower is large, oval and vein'd; the margins reflex'd and elevated: the pod is above an inch long, cylindrical, a little curved at the end, and contains from four to nine feeds,

The highlanders have a great efteem for the tubercles of the roots of this plant; they dry and chew them in general to give a better relifh to their liquor; they alfo affirm them to be good againft moft diforders of the thorax, and that by the ufe of them they are enabled to repel hunger and thirft for a long time. In Breadalbane and Rofshire they fometimes bruife and fteep them in 


\section{DIADELPHIA DECANDRIA.}

water, and make an agreeable fermented liquor with them. They have a fweet tafte, fomething like the roots of liquorice, and when boiled, we are told, are well flavour'd and nutritive, and in times of fcarcity have ferv'd as a fubftitute for bread.

Sylvaticus 2 OROBUS caulibus decumbentibus hirfutis ramofis. Lin. Jy/t. nat. 485. Sp. pl. 102g. (AEZ. Paris. 1706. p. 87.t. 90. Eं fig. noft.)

Wood-Vetch, or Bitter-Vetch. Anglis.

Upon dry rocky places, and the banks of rivers, but rare. We obferved it upon the bank of the Clyde, near Lanerk, between the two famous falls of Corry's-Lyn and Bonnatyn, and in the inand of $R$ um, on the bank of a rivulet running down a mountain called Baikevall. 22. VII.

Miany hairy reclining angular ftalks, about a foot high, arife from the fame root, and, as far as we obferved, unbranched: the leaves grow alternate, ten or twelve upon a ftalk; they are pinnated, and generally hairy; the number of pimne are from feven to eleven pairs, of an oval acute form, ftanding on hort pedicles on a hairy rib, which is not terminated with an odd pinna, but a fmall point or beard: the fipule grow in pairs, Thaped each like half the perpendicular feetion of the barb of an arrow: the flowers grow ten or twelve together, in a clofe fpike or clufter, all leaning the fame way, upon a hairy peduncle as long as the leaf, and arifing from the ala 


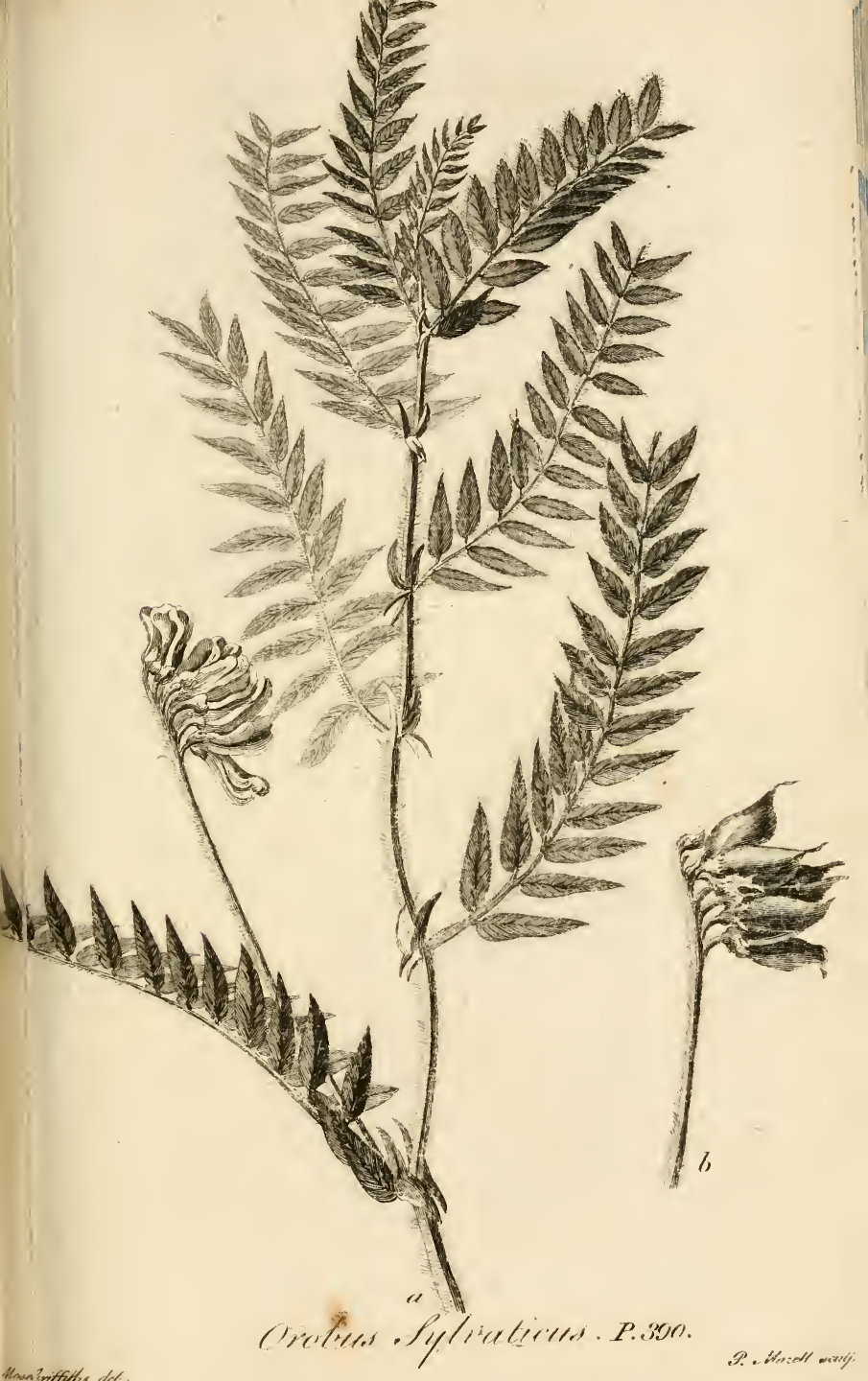



of it: the flowers are white, ftriated with purple veins; the apex of the carina is a bright purple: the calyx is hairy and reddin : the pods are hardly an inch long, compreffed and fmooth, and contain about three feeds.

The whole plant has a difagreeable bitter tafte.

\section{LATHYRUS. Gen. pl. $8 i^{2}$.}

Stylus planus, fupra villofus, fuperne latior. Cal. laciniz fuperiores 2 breviotes.

ratenfis r. LATHYRUS pedunculis multiforis, cirrhis diphyllis fimplicifimis, foliolis lanceolatis. $S p . p l$. 1033. (Ger. en. 1231. f. 6. Rivin. t. 43 Baub. bift. 2. p. 304. t. 304. Moris. bift. S. 2. t. 2.f. 2. Oed. Dan. t. 527. opt.)

Yellow Vetchling, Tare-everlafting. Anglis.

In meadows and paftures, where the foil is moint, both in the highlands and lowlands. 24. VII. VIII.

The ftalks are branched, quadrangular, a cubit long or more, weak, and unable to fupport themfeives: the tendrils are generally fingle, but often trifid, fubtended by one pair of oval-lanceolate pima, which have three nerves, and are moft commonly a little downy: the foipula are haftate, and as large as the pinne: the floral ftalk is axillary, and bears a fpike of eight or ten yellow flowers: the pods are fhort, broadifh, and a litthe curv'd: the feeds round and yellowin. 
It is an excellent fodder, and fome foils would pro. bably reward the hurbandman's cultivation. The badger is faid to feed upon it.

Seref?ris 2. L. pedunculis multiforis, cirrhis diphyllis, foliolis enfiformibus, internodiis membranaceis. $s p$. $p l$. 1033. (Rivin. t. 39. Moris. bift. S. 2.t. 2. f. 4. bona. Oed. Dan. t. 325. optima.)

Narrow-leav'd Peafe-everlatting. Anglis.

In dry rough Mrubby places, and by wood-fides, but rare. Sibbald. 24. VII. VIII.

The ftalk is a yard high, wing'd with two membranous angles, diffufely branched, weak and climbing: the leaves are long and lanceolate, have three nerves on the under fide, and the rib to which they grow is wing'd: the tendrils are trifid and branched, often trichotomous : the fitpulce are narrow and fubulate at both ends, their lower points preffing the ftalk: the foral peduncle is five or fix inches long, bearing a fpike of four to eight flowers: the vexillum is of a rofy purple color, reticulated with deeper veins: the ale or fide-petals are of a blueifh purple: the sarina, or keel-petal at the bottom of the flower is of a pale green: the pod is narrow, cylindrical, and two inches long.

foluffris 3 .

LATHYRUS pedunculis multiforis, cirrhis polyphyllis, ttipulis lanceolatis. $S \% \cdot p l .1_{34}$. (Plak. Alm. t. 7r. f. 2. Oed. Dan. t. 399. opt.) Marth Chichling Vetch, Marm Latbyrus. Anglis. 
By the fides of lakes, and in marfhy or boggy grounds, but rare. 24. VII. VIII.

The ftalk is two feet high, wing'd with two membranes, weak and branched towards the top: the leaves are of an elliptic-lanceolate form, generally three pair upon a rib : the tendrils are trifid: the fipula are broad, femi-elliptical, acute at both ends, and dentated externally below the middle: the Braftece are fmall and lanceolate: the peduncles are three inches long, and produce about fix or eight purple flowers, with veined petals: the pods are fmooth and a little com. preis'd.

\section{VICIA. Gen. pl. 873 .}

Stigma latere inferiore tranfverfè barbatum.

* Pedunculis elongatis.

Givatica 1. VICIA pedunculis multifloris, foliolis ovalibus, ftipulis denticulatis. Sp. pl. 1035. (Pluk. Alm. t. 7 I.f. I. Haller. hift. Jirp. Helvet. v. I. $\pi .426 . t$. 12. p. 172. fig. ad dextram; fed fal. nimis acutis. Oed. Dan.t. 277. opt.)

Tufted Wood-Vetch. Anglis.

in Ahrubby places at the foot of mountains and rocks, but not common, as under Salifoury-Craigs, and at Cartland rocks, near Lanerk, \&c. 24. VII. VIII.

The ftalks of this elegant plant are angular, branched, weak and climbing, three or even fix feet, and have numerous leaves: the ftipula are deeply 
deeply and acutely denticulated, and the dents bearded: the leaves have eight or ten pair of oval pinne growing commonly alternate, the middle nerve of each pinneterminated in a point or fpinule: the tendrils are bifid and greatly curled : the floral ftalks arife from the cla of the leaves, are four or five inches long, and bear a pike of 15 or 20 white pendulous flowers, Areaked with blue veins : the carina or keel-petal is obtufe, and blue at the aptx: the pod is fmooth, but little lorger than the flower, and contains from four to fix globular feeds.

22. VICIA pedunculis multifloris, foribus imbricatis, foliolis lanceolatis pubefcentibus, ftipulis integris. Sp.pl. 1035. (Rivin. t. 49. Perkins. 1072. Moris. bift. S. 2.t. 4.f. 1. Sed̀ malè.)

Tufted Vetch. Anglis.

Peafair-luch na coille. Gaulis.

In corn fields, pantures, and buthy places frequent. 24. VII. VIII.

The Atalk is two or three feet high, furrow'd, weak and branched: the leaves are pinnated with 12 or more pairs of pinne, of a narrow-elliptical form, hairy, deflex'd, rather blunt at the erd, the nerve terminating in a fhort fpinule: the tendrils are great flowers grow 30 or more in a long pendulous fpike, all on the fame fide of the ftalk, imbricated cownwards, fmall, but make an elegant. 


\section{DIADELPHIA DECANDRIA.}

appearance, being of a violet-purple color, the carina marked with two blue fpots: the pod is fhort, tumid, hroadifh, and contains eight or ten black globular feeds.

It is reckoned to be a good fodder for cattle.

\section{* Floribus axilloribus, Jefrilibus.}

fativa 3. VICIA leguminibus fefflibus fubbinatis erectis, foliolis retufis, ftipulis notatis. $S p . p l$. 1037. (Ger. em. 1227. f. 1. Rivin. t. 55. Moris. hift. S. 2. t. 4 . f. 12. Oed. Don. t. 522 .

Common Vetch, or Tare. Anglis.

In corn fields frequent. $\odot$. VI.

The whole plant is hairy: the ftalk a foot high, ftriated and weak : the leaves confint commonly of five or fix pairs of pinne, which are either heart-Phap'd, or obtufely lanceolate, or oval, or linear, the nerve ending in a point: the tendrils are trifid: the ftipule dentated, and marked with a dark red fpot, which looks as if it had been burnt in : the flowers are of a blueifh red, or purple color, growing two together from the ala of the leaves, and oftentimes only one, on very fhort peduncles: the dents of the calyx are all ftrait, the under ones the longeft: the pod is hairy when young, but grows fmoother by age, and contaisus from five to ten feeds, generally of a pale green color, with black fpots, but in fome varieties almoft black or white.

It is known to be an excellent fodder for horfes: in 
fome parts of Enrland the crop is plough'd in to anfwer the purpofes of manure to the land: pigeons are very fond of the feeds, and in fome parts of saveden, \&c. they enter into the compofition of bread, either alone, or mixed with the flour of rye. In England a decoction of them in water is fometimes given by nurfes to expel the fimall-pox and meanes.

VICIA leguminibus feffilibus folitariis erectis glabris; foliolis fenis, inferioribus obcordatis. $S_{p}$. pl. 1037. (Ger. em. 1227. f. 4. Herm. parad. t. 242. Rivin. tetr. 169. Oed. Dan. 1. 58.)

Strangle Tare, or wild Vetch. Anglis.

In dry paftures, and in gravelly and fandy foils frequent, as in the king's park at Edinburgh, and in Leith gravel pit, \&c. Dr. Parfons. ๑. V. VI.

Several taiks, from three to $f x$ inches long, arife from the fame root, and fpread upon the ground: the lower leaves are pinnated with one or two pairs of heart-hap'd pinne, but the upper ones moft commonly with three pairs of elliptical acute ones: the fipule are acute at both ends, hooked at the bafe and entire on the fides; the tendrils generally fimple and unbranched: the flowers are fmall and purple, often verging to lue: the pod is fmooth, and contains from fix to ten feeds : the ftalk and leaves are downy: we have fornetines oblerved the feeds to affume a cubical thape, which we confider only as a variety 


\section{DIADELPHIA DECANDRIA.}

riety, tho' we fufpect it has been miftaken for the ERVUM Solonien $\int e$ of Linneus.

Sepium 5. V. leguminibus pedicellatis fubquaternis erectis, foliolis ovatis integerrimis, exterioribus decrefcentibus. Sp. pl. 1038. (Ger. em. 1227.f.2.)

Bulh-Vetch. Anglis.

In woods and fhady places not unfiequent. 4. VI.

The ftalk is angular, fmooth, and two or three feet high: the leaves have from five to eight pair of pinne, of an oval-obtufe form, emarginated, nightly hairy, decreafing gradually in fize towards the extremity, the nerve terminating in a point: the fipule are fmall, oval, acute, and marked with a dark red fpot: the tendrils are branched: the flowers grow from three to five in a clufter or fpike, upon a very fhort peduncle : the calyx is of a livid color, hairy, and friated: the flower of a dull blue, reticulated with veins of a deeper color: the pods are fhort, erect, and contain five or fix globular fpotted feeds.

It is faid to be a good fodder for cattle.

\section{ERVUM. Gen. pl. 874.}

Cal. 5-partitus, longitudine corollæ. Stigma capitatum, inberbe, obtufum.

tetrajpermum $\mathrm{I}$.
ERVUM pedunculis fubbifloris, feminibus globofis quaternis. Sp. pl 1039. (Moris. bift. S. 2. t. 4. f. 16. Rivin. t. 53. Oed. Deil. t. 95. opt.)

Little fmooth Tare. Anglis. 
In corn fields, but not very common. $\odot$. VI. ViI. The ftalk is two-edg'd, obfcurely quadrangular, humble, weak and branched: the leaves have from three to five pair of linear fpear-fhap'd pinna, growing generally alternate, but often oppofite: the ftipule are entire, and hooked at the bafe : the tendrils bifid and branched : the peduncles arife from the alie of the leaves, erect, very flender, and generally bear two flowers, but fometimes one only : the flower is very fmall, the vexillum purple or blueifh, the alde white, the apex of the carina blue: the pod is fmooth, mort, obtufe, and contains three or four tumid feeds.

birfutum 2. E. pedunculis multifloris, feminibus globofis binis. Sp.pl. 1039. (Ger.em. 1028.f. 5. Rivin.t. 53.) Little hairy Tare. Anglis.

In corn fields frequent. $\odot$. VII.

The ftalk is a cubit high or more, weak, and branched: the leaves have 10 or 12 pairs of nearly linear pinne, growing alternate: the lower ftipulce are dentated, the upper ones entire : the tendrils branched : the floral peduncles are two inches long, and bear from three to five fmall bluein white flowers the apex of the carina is blue: the pod is thort, broad, acuminated, hairy, pendulous, and contains two black fpotted feeds. 
ORNITHOPUS. Gen.pl. 884.

Legunen articulatum, teres, arcuatum.

perpufilius

I.

ORNITHOPUS foliis pinnatis, leguminibus fubarcuatis. sp. pi. Iо40. (Ger. em. 12+1. f. 3 . Moris. bift. f. 2. t. 10.f. I3.)

Bird's-foot. Anglis.

In gravelly or fandy grounds, but not common. Mr. Stuart obferved it about Comrie, a village four miles from Crief, in Strath-Ernic. ○. VI. VII.

The ftalks are fix or eight inches high, and lie proftrate upon the ground : the leaves have about 15 pair of very fmall, oval, foft, hairy, and nearly equal pinne, with sn odd one at the end: the peduncles arife from the alc of the leaves, and bear a kind of half-umbel, confifting of three or four fmall yellow flowers, the vexillum tinged with red: the pods are nightly hairy, cuived, jointed with fix or eight articulations, and terminated with a claw, fo that altogether they not unaptly reprefent a bird's foot. Each joint contains a fingle feed.

ASTRAGALUS. Gen. $p l, 8 g z$.

Leguiaen biloculare, gibbum.

* Coulliuus foliojis diffusis.

glycyphillos ASTRAGALUS caulefcens proftratus, legumini1. bus fubtriquetris arcuatis; foliolis ovalibus pedunculo longioribus. sp. pl. 1067. (Ger. sm. 
1233. f. 2. Rivin. t. 103. Moris. bif. f. 2. t. g. f. 8.)

Wild Liquorice, or Liquorice Vetch. Anglis. In woods, but not common, as in Corytion woods, five miles from Edinburgh. Dr. Parfons. 4- VII. The ftalks are two feet long, branched and proftrate: the leaves have four or five pair of oval pinna, with an odd one at the end: the peduncles are fhorter than the leaves, and arife from their ale, bearing a thort fpike of about 12 pale yellow flowers, fucceeded by erect, turgid and curved pods, having each two cells, containing eight or ten kidncy- Thap'd feeds.

The leaves have a fweetin tafte, mix'd with bitternefs. An infufion of them has by fome been recommended in fuppreftions of urine, and for the gravel.

arcnarius 2 ASTRAGALUS fubcaulefcens procumbens, floribus fubracenofis erectis, foliis tomentofis. i $p$. pl. Ic6g. (Raii. Synop. p. 326. t. 12. f. 3. cum leguminibus. bona.)

Purple Mountain Milkwort. Anglis.

On dry mountainous paftures, but not very conmon, as upon the hills in the king's park at Edinburgh, upon the fands of Mufelburgh, upon the hill of Moncreif, near Perth, and in dry ground near Yurk.Calcade, at the feat of the Duke of Athol's, at Blair, \&c. 24. VII.

The ftalk, together with the peduncle, is from theree 



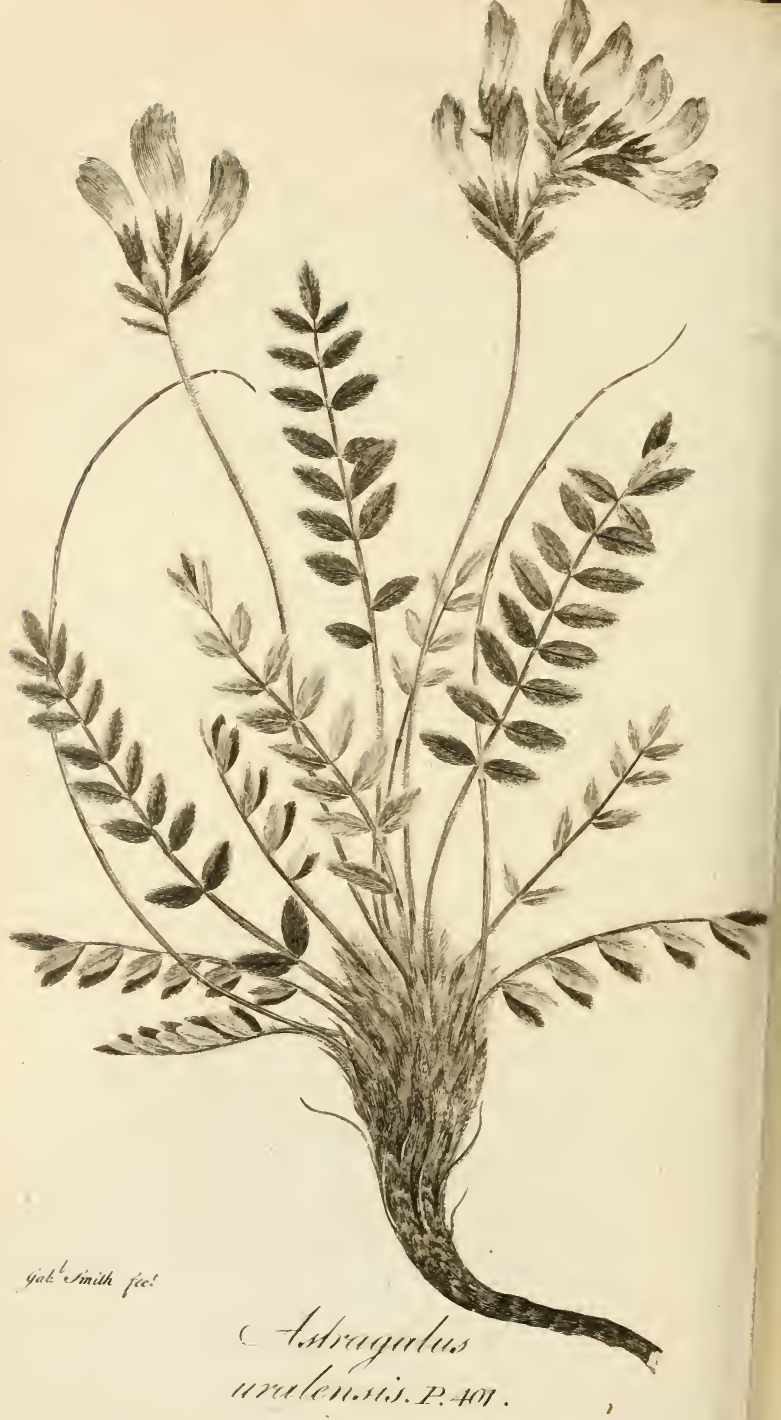




\section{DIADELPHIA DECANDRIA.}

three to fix inches high, procumbent at the bafe: the leaves have ten or twelve pair of fmall, hairy, elliptical pinna, with an odd one at the end: the peduncle: is longer than the leaves, and bears at the top a clutter of about fix purple flowers: the calyces are covered with black hairs: the pods are hort, oval, inflated, hoary, and white with woolly hairs.

\section{* Scapo nudo, absque coule foliofo.}

ralenfis 3. A. acaulis, fcapo erecto foliis longiore, leguminibus fubulatis inflatis villofis erectis. $S p . p l .107 \boldsymbol{t}$. (Haller. opufc. t. 2. fig. media. Hift. Airp. Heivet. n. 410. t. 14. fig. infer. adfiniftram. E' fig. noft.) Silken Aftragalus. Anglis.

Upon Carn-dearg, one of the lower heads of BenSguilert, a high mountain in Glen-creran, in Upper-Lorn, growing together with plenty of the DRYAS octo-petala, in a light fandy foil : found there by my ingenious friend Mr. Stuart.

It has alfo been difcovered at the bay of Farr, on the eaftern coaft, and in a rocky foil at Cronlarty, by Mr. Robertfon. See Scotch magazine for fuly 1768, with a figure of it. 4. VII.

The root is long and woody: the ftalk is five or fix inches high, deftitute of leaves, foft and downy: the leaves are all radical, and confift each of ten or twelve pair of oval-acute pinne, covered with a white filky down: the flowers are of a pale violet color, and grow eight or ten to-

D d gether 


\section{DIADELPHIA DECANDRIA.}

gether in a Short thick fpike at the top of the Italk : the calyx is covered with the fame fhining hairs as the leaves: the Bractea are fubulate and thorter than the calyx : the pod is hairy, turgid, hard, and has two cells containing feveral feeds.

\section{TRIFOLIUM. Gen. pl. 896 .}

Flores fubcapitata. Legumen vix calyce longius, non dehifcens, deciduum.

* Meliloti leguminibus nudis polyfpermis.

mel. offici- TRIFOLIUM leguminibus racemolis nudis, difnalis I. permis, rugofis, acutis, caule erecto. $S p . p$. 1078. (Ger. em. 1205. f. 4. Rivin. t. 6. Moris. bift. f. 2. t.16.f. 2. ordinis medii. Blackwell t. 80.) Melilot. Angiis.

In corn fields and by way-fides, but not common: beyond Drummond-Lodge, near Edinburgh. Dr. Parfons. And near Aberlady, in the Links. Sibbald. 8. VII.

The ftalk is erect, firm, ftriated, branched, and two or three feet high : the leaves ternate, fmooth, obtufely oval, and ferrated: the flowers are imall, yellow, pendulous, and grow in long clofe Spikes at the tops of the branches: the pod is very thort, turgid, tranfverfely wrinkled, pendulous, and contains either one or two feeds.

The plani has a very peculiar ftrong fcent, and difagreable bitter acrid tafte, but fuch however as 
is not difpleafing to cattle. The flowers are fweet-fcented.

It has generally been efteemed emollient and digeftive, and been ufed in fomentations and cataplafms, particularly in the plafter employed in dreffing blifters, but is now laid afide, as its quality is found to be rather acrid and irritating than emollient or refolvent.

It communicates a moft loathfome flavor to wheat and other grain, fo as to render it unfit for making bread.

irnitbopo- TRIFOLIUM leguminibus nudis octofpermis fub dioides 2. ternis calyce duplo longioribus, caulibus declinatis. Sp.pl. 1078. (Pluk. t. 68.f. 1. mala. Raj. Synops. p. 331. t. 14. f. 1. Oed. Dan. 368. opt.)

In dry or fandy paftures, but rare. Rev. Dr. Burgefs of Kirkmicbael. $\odot$. VI. Birds fort Trefocic-

The branches are three or four inches long, and lie proftrate and clofe to the ground about the root: the leaves ternate, heart-fhap'd, ferrated, and ftand on long foottalks: the fripule are lanceolate and grow in pairs: the peduncles are axillary, fhorter than the footftalks of the leaves, and bear molt commonly two, but fometimes three or four narrow pale red flowers: the pods are fhort, blunt, erect, and nightly recurv'd, each containing fix or eight feeds.

* Lotoidea leguminibus testis, polyspermis.

$\mathrm{D} d 2$

TRIFOLIUM 
TRIFOLIUM capitulis umbellaribus, leguminibus tetrafpermis, caule repente. $S p . p l .1080$. (Rivin. t. 13. Moris. bift. S. 2. t. 12.f. 2. ordinis fuperioris, छ' t. 14. $f .4$, ordinis Juperioris. Micbel. Gen. t. 25.f. 5. Vaill. Paris.t. 22.f. I.)

White creeping Trefoil, or Dutch Clover. Anglis. Seamar, Seamrag. Gaulis.

In meadows and paftures common. 4 . VI-IX.

The ftalk is round, unbranched, creeping, and about a fpan long: the fipule are of an ovallanceolate form, and vein'd : the leaves are generally ferrated, but variable in their figure, being either roundifh and obtufe, or emarginated and heart-1hap'd, commonly fmooth and nervous, and often marked with a white arch: the pedunare very long, and have a pair of fipule at the bafe: the flowers grow in a fphærical depreffed head: the younger ones are white and erect, the older a little reddith and deflex'd: the calyx is either white or purplifh, marked with ten ftreaks : the feed-veffel appears out of the calyx, and in fair fpecimens contains four feeds, though often only two.

It is well known to be an excellent fodder for cattle, and the leaves are a good ruftic hygrometer, as they are always relaxed and flaccid in dry weather, but erect in moift or rainy.

*** Lagopoda calycibus villofis.

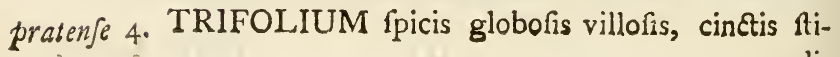
pulis 
pulis oppofitis membranaceis, corollis monopetalis. Sp. pl. 1082. E' Mantifs. Secund. p. 451. (Moris. bift. f. 2. t. 12.f. 6. Rivin. t. I I. Blackwell t. 20. Ev var. Raj. Syn. p. 328. t. I 3.f. I.) Purple Trefoil or Clover. Anglis.

In meadows and paftures frequent. 4. VI-IX.

The ftalks are numerous from one root, reclining at the bafe, and branched: the Ripule are white, marked with red veins, and terninated with capillary beards: the leaves have fhor footflalks, and are downy, the lower ones of a roundifh oval figure, the upper ones more acute, and generally marked with a white arch: the head of flowers is roundifh, purple, and feflile, placed between two oppofite, ternate, feffile leaves, which are fubtended by a pair of broad membranaceous fipule, ferving the purpofe of a common calyx: the calyx is ftreaked with ten lines, and is tubular and hairy: the fegments are capillary, ciliated on the fides, the lower one by much the longent: the tube of the Corolla is longer than the Vexitlum or upper petal, which is plaited, ftrait, and reflex'd on the edges.

It affords a very plentiful fodder to horfes and other cattle, but when they feed too greedily on the frefh herb, it blows them up in fuch a manner with wind, that unlefs they are fpeedily relieved by tapping them in the belly, or fome other fimilar operation, they foon perifh. In Ireland the poor people, in a fcarcity of corn, make a kind

$$
\mathrm{D} d 3
$$


of bread of the dry'd flowers of this and the preceding plant reduced to powder. They call the plant Cbambroch, and efteem the bread made of it to be very wholfome and nutritive.

alpefte 5. TRIFOLIUM fpicis fubglobofis villofis terminallbus fefilibus, caule erecto, foliis lanceolatis ferrulatis. Sp. pl. 1082. (Rivin. t. 12. Jacquin. obs. 3. p. 14.t. 69)

Mountain Clover. Anglis.

At the foot of the highland mountains not unfrequent, in moift or fhady places. 2\%. VII.

It differs from $T$. pratense, in having green fipula, lanceclate at both ends, neither ftreaked with red veins nor bearded; in having longer leaves, more nervous, fmooth on the upper fide, and rarely marked with any fpot or arch: the calyx ftriatec and fmooth, the dents only hairy: the heads o: flowers more oval, larger, 'and of a deeper pur p!e, two of them frequently terminating the branch.

arvinje 6. T. fpicis villofis ovalibus, dentibus calycinis fetacei villofis acqualibus. Lin. Jy/f. nat. p. 503 . Sp. p. 1083. (Ger. em. 1192. f. 3. Rivin. t. 15 Barrelier ic. gor. 902. Moris. bift. J. 2. 1. 13. f. 8. Black well $t$. 490.)

Hare's-foot Trefoil. Anglis.

In corn fields and dry barren paftures not unfre quent, as under Salifbury craigs, \&rc. $\odot$. VI VHI. 
The ftalk is ereet and branched, and the whole plant covered with a foft down: the leaves are narrow, and nearly linear, emarginated at the end, the nerve terminated with a fpinule: the fipule are linear, and have long beards : the ftalk and branches are terminated with oval or cylindrical fpikes, covered with a thick anh-color'd or reddifh down: the calyx is bell-hap'd and hairy, and has five dents, which are longer than the flower, and are feathered with down: the Corolla is very fmall and reddifh: the feed-veffel is tumid, fphærical, and contains one feed.

It is fuppofed to have an aftringent quality, and has fometimes been ufed in dyfenteries, but is not known in the prefent practice.

abrum 7. TRIFOLIUM capitulis feffilibus lateralibus ovatis, calycinis laciniis inæqualibus rigidis recurvis. Lin. Jyft. nat. p. 543. Sp. pl. 1084. (Barrelier ic. 870. Vaill. Paris. t. $33 \cdot f$. I.)

Hard-knotted Trefoil. Anglis.

On dry foils by the fea Thore near Edinburgh. Dr. Parfons. $\odot$. VI.

The root throws out feveral tough proftrate ftalks, about four inches long: the leaves are a little hairy, veined, wedge-lhaped, or wideft and rounded at the end, and very finely crenated: the fipule are oval and acute: the heads of flowers fmall, nightly oval, axillary, feffile and rigid: the dents of the calyx are tharp and Atiff, unequal 
unequal in length, open and recurv'd when old : the flowers whitifh, a little longer than the calyx, and rarely opened.

friatum 8. T. capitulis feffilibus fublateralibus ovatis, calycibus ftriatis rotundatis. S. pl. 1085. (V aill. Paris t. 33. f. 2. R. Synop. p. 329 T. 13.f. 3.) Soft-knotted Trefoil. Anglis.

In dry paftures, as in Edinburgh park, abundantly. ๑. VI.

This varies with reclining and erect ftalks, from five to ten inches long, and the whole plant is cover'd with foft hairs: the upper lcaves are wedge-lhap'd and nightly crenated, the lower ones are heartThap'd: the ftipulce are widely oval, membranaceous, and ftriated with red branched lines: the heads of flowers are foft and oval, the upper ones feffile, but the lower ones fometimes have fhort footftalks : the calyces are covered with foft white hairs, and Atreaked with ten prominent lines, and when old become round and inflated : the dents are fhort, and terminated with night fpinules: the flowers are of a pale red color.

This plant differs fo little from the preceding, that we have been tempted to think them only varieties, arifing from difference of foil; but as all authors have diftinguilhed them as fpecies, we were unwilling to diffent from the general opinion. 
*** Lupulina vexillis corolle inflexis.

agrarium 9 TRIFOLIUM fpicis ovalibus imbricatis, vexillo deflexis perfiftentibus, calycibus nudis, caule erecto. sp. pl. 1087. (Ger. em. 1186.f. 6. Moris hift. f. 2. t. 13.f. 1 Eं 2. majus. Vaill. Paris. t. 22.f. 3 . opt.)

Hop Trefoil. Anglis.

In dry paftures and corn fields frequent. $\odot$. VI. VII.

The ftalks are hard, branched, a foot high, generally erect, but fometimes procumbent: the leaves are nervous and fmooth, and either nearly oval or cordate, or like the fector of a circle, with the rays entire and the arc ferrated: the fitpule are largeft near the top of the ftalk, and of an oval-lanceolate figure: the floral fpikes grow on long, naked peduncles, nearly oval, and confift of numerous flowers, clofely fet together: the flowers are yellow, and ftand each on its own fhort pedicle, and when ripe are pendulous, dry, and ruftling: the calyx, except two or three hairs at the apex, before flowering is fmooth : the vexillum is heart-fhap'd, deflex'd, ftriated, and nightly ferrated : the filique contains one oval, thick feed, ftanding on a pedicle.

It is an excellent fodder for cattle.

procumbens T. fpicis ovalibus imbricatis, vexillis deflexis per10. fiftentibus; caulibus procumbentibus. $s p . p l$. 1085. 
1088. (Moris. bift. f. 2. t. I3-f. I E 2. minus, ad bajin. Fig. Raj. Synops. 1. 330. t. J4.f. 3)

Procumbent Trefoil. Anglis.

In paftures frequent, $24 . \mathrm{VI}$. VII.

The ftalks are generally procumbent when young, but afterwards become more crect, often a foot long, and but little branched: the leaves are Imall, heart-thap'd, and finely ferrated, but not friated: the fpikes are lax, and contain from ten to fixteen flowers, which are fmaller than thofe of the preceding.

scopoli, in his Flor. Carniolica, n. 93I, feems to think this only a variety of the $\mathrm{T}$. agrarium, and indeed it differs but little from it.

Eliforme I I TRIFOLIUM fpicis fubimbricatis, vexillis deAexis perfiftentibus, calycibus pedicellatis, caulibus procumbentibus. Sp.pl. 1088. (Raj. Syn. p. 33 t. t. $14 \cdot f \cdot 4)$

Siender-ftalk'd Trefoil. Anglis.

in dry fandy foils, and upon ant hills, but not very common. $\odot$. VI.

The ftalks are about four or five inches long, very fine and llender, and generally procumbent : the leaves are ftriated and emarginated : the peduncles are fcarcely bigger than a horfe-hair, but longer than the leaves, and funtain from three to five fmall yellow Alowers, the calyces of which, during fructification, are much more evidently fupported 


\section{DIADELPHIA DECANDRIA.}

fupported on pedicles than thofe of the preceding fpecies: the flowers are pendulous.

It has been proved, by fowing the feeds, to be a diftinct fpecies from the foregoing, but in the cultivated ftate was obferved to produce from $\mathrm{I2}$ to $I_{b}$ flowers in a clufter on each common peduncle.

\section{LOTUS. Gen. pl. 879 .}

Legumen cylindricum, ftrictum. Ale furfum longitudinaliter connivens. Calyx tubulofus.

corniculatas J.

LOTUS capitulis depreffis, caulibus, decumben. tibus, leguminibus cylindricis patentibus. $S p \cdot p l$. 1092. (Ger. em. I Igo. f. 5. Rivin. t. 76. Moris. bift.f. 2. t. 18.f. 10 E II.)

Bird's-foot Trefoil. Anglis.

Bàr-a'-mhilfein. Gaulis.

In meadows and paftures common. 4. VI-VIII,

The ftalks vary in length from fix inches to a cubit, and are generally proftrate, but fometimes nearly erect: the leaves are ternate, and commonly of an oval-lanceolate form, but fometimes roundirh, and in other varieties narrow and almoft linear: the fipule grow in pairs, oval and acuminated, much like the leaves: the peduncles are axillary, and bear a coronet of four or five yellow flowers : the vexillum is nearly oval, plaited, erect, ftreaked with red lines, or ever. quite red before it opens, and ftands on a pedi. 
cle remote from the other petals : the filaments are dilated at the apex: the antberce ftand on pedicles: the pods are an inch long, of a reddin brown color, fmooth, fhining and divaricated, or fpreading out from one another.

The plant varies with hairy and fmoo:h leaves and calyces.

It is an excellent fodder for cattle, and would probably be well worth attention in agriculture.

The infect called by Linneus THRIPS glauca fometimes renders the flowers tumid and montrous.

\section{MEDICAGO. Gen. pl. 899.}

Legumen compreffum, cochleatum. Carina corollx a vexillo deflectens.

lupulina 1. MEDICAGO fpicis ovalibus, leguminibus reniformibus monofpermis, caulibus procumbentibus. Lin. Sylt. nat. p. 506. Sp. pl. 1097. (Ger. em, 1186. f. 5. Rivin. t. 8.)

\section{Melilot Trefoil. Anglis.}

In corn fields and paftures frequent. $\hat{\jmath}$. VI-VIII.

The ftalks are numerous, branched, from eight inches to a foot long, and lie proftrate on the ground: the leaves are ternate, of a variable figure, being either oval, heart-Ihap'd or roundifh, finely ferrated, foft, a little hairy, and fupported on footflalks: the peduncles are axillary, and bear an oval, imbricated head of finall yellow flowers : the vexillum is large, oval, reflex'd, and hides the other petals : the feed-veffels grow in 
an oblong clufter, are kidney-lhap'd, wrinkled, black when ripe, and contain each an oval feed.

It has of late years been cultivated in fome parts of England for fodder, but it is probable that the LOTUS corniculatus, and TRIFOLIUM agrarium abovementioned, would turn to a better account. 
C L A S S I S XVIII.

P O L Y A D E P H I A. P O L Y A N D R A.

HYPERICUM. Cal. 5-partitis, inferus. Cor. 5petala. Styli I, 3, feu 5. Caps. 1, 3, s. 5locularis. 


\section{L A S S I S XVIII. \\ $P O L Y A$ II $D R$ I A.}

HYPERICUM. Gen. pl. 902.

Cal. 5-partitus. Petala 5. Filamenta multa, in 5phalanges bafi connatà. Cops. loculis numero ftylorum.

\section{Trygina omnia.}

endrofco= mum I.

HYPERICUM foribus trygynis, pericarpiis baccatis, caule fruticolo ancipiti. Sp.pl. 1102 . (Ger. em. 543.f. I. Moris. bift. $\left.\int .5 \cdot t .6 . f .12\right)$

Tutfan or Park leaves. Anglis.

In woods, but not very common. We obferved is in the woods at Inverary, and at Locb-Ransa, in the ine of Arran. 5. VII.

The ftalk of this Thrub is branched, and has two angles: it is commonly about two feet high: the leaves are large, oval, fmooth, oppofite and feffile, turning to a dark red color in the autumn : the juice exprefs'd from them is claret-color'd : the flowers are yellow, and grow in a thin clufter or umbel of five or fix together, at the fummits of the branches, one, two or three upon a peduncle : the fegments of the calyx are oval, green, fomewhat larger than the petals, and remain after the petals are fallen: the pericarpium is a fpliærica: 


\section{POLYADELPHIA POLYANDRIA.}

fphærical berry, firft green, afterwards red, and foft and black when ripe, containing many reddifh feeds.

It is a good vulnerary, the leaves readily healing any frefh wounds, whence it took the French name of Tutfan or Tout-Jain, i. e. All-heal.

quadrangu- HYPERICUM floribus trigynis, caule quadrato lum 2. herbaceo. Sp. pl. I104. (Ger. em. 542. f. I. Moris. bift. . . 5. t. 6. f. 10. Pet. berb. t. 60.f. 11.) St. Peter's Wort. Anglis.

In moift paftures, and by the fides of ditches and rivulets. 24. VII.

The ftalk is a foot high, wing'd with four angles : the leaves are oval, imperforate, and have nine nerves: the calyx is without glands: the petals are marked towards the top with black glandular dots on the margin.

perforatum H. foribus trigynis, caule ancipiti, foliis obtufis 3 . pellucido-punctatis. I 105. sp. pl. (Ger. em. 539. f. 1. Moris. hijt. S. 5. t. 6.f. 1. Blackwell t. 1 5.) St. John's Wort. Anglis. Achlafan-Challum chille. Gaulis. In woods, thickets and hedges. 4. VII. The ftalk is a cubit high, and has two elevated lines; otherwife is round, fmooth, and branched. The leaves are oval and obtufe, and marked with fmall, black, glandular dots on the margin, and if held up between the eye and the light ap- 
pear as if perforated on the furface, being punctated with numerous pellucid veficles. The flowers are yellow and grow in clufters terminating the branches, and forming a kind of umbel. The petals are mutilated, or feem to have a fnall piece cut out on one fide, and are denticulated on the other; their margins towards the top, and fometimes the whole furface is fprinkled with black dots. The leaves of the calyx are intire, without glands, and about half the length of the petals. The antbere are marked with a fmooth black fpot, or lateral gland, placed on the feptum between the two lobes. The figmate are of a dark red color.

An oil or tincture of the flowers is efteemed a good vulnerary. The exprefs'd juice or infufion of the fame is reckoned good to deftroy worms, to refolve coagulated blood, and to promote urine.

The dried plant boiled in water with alum, dyes yarn of a yellow color, and the Swedes give a fine purple tinge to their fpiritous liquors with the flowers

The fuperftitious in Scotland carry this plant about them as a charm againft the dire effects of witchcraft and enchantment. They alfo cure, or fancy they cure their ropy milk, which they fuppofe to be under fome malignant infuence, by putting this herb into it, and milking afrefh upon it. 
HYPERICUM floribus trigynis axillaribus folita4.

riis, caulibus ancipitibus proftratis filiformibus, foliis glabris, $s p$. pl. I 105. (Ger. em. 541. f. 4 . Pet.berb.t.60.f. 8. Oed. Dan.t. I4 r.)

Trailing St. John's Wort. Anglis.

In gravelly paftures, but not very common. Dr. Parfons \& Sibbald. 24. VII.

The ftalk is about five or fix inches long and proftrate. The leaves are not abfolutely without pellucid dots, but are obfcurely perforated. The flowers do not form an umbel, but grow fingle upon the peduncles arifing from the ale of the leaves. The calyx is ferrated, and fprinkled with black fpots or glands, particularly on the edges. In other refpects it differs little from the preceding.

montanum

H. Aloribus trigynis, calycibus ferrato-glandulofis, 5 . caule tereti erecto glabro foliis ovatis glabris. Lin. Jys. nat.p. 5 10. Sp. pl 1105. (Column. Ecplorns. I. p. 73. t. 74. Moris. bift. S. 5.t. 6. f. 9. Pet. berb. t. 60. f. 7. Oed. Dan. t. 173. opt.)

Imperforate or Mountain St. John's-Wort. Anglis. In mountainous woods, but not common. Sibbald. 4. VII.

The ftalk is about a cubit high, very little branch'd, and naked for a confiderable diftance under the flowers. The leaves are few, vein'd, the lower ones imperforate; their edges red, and marked 
with black glands. The flowers grow in a fhort fpike or clufter, and are but few in number. The fegments of the calyx are lanceolate and ferrated, each ferrature having a refinous gland upon its apex. The bractere are ciliated with the like glands. The petals are fometimes, out not always, dotted towards the top. The antbere have each a black fpot or glandule near the bafe. The famina are divided only into three phalanxes.

birfutum 6. HYPERICUM foribus trigynis, calycibus ferratoglandulofis, caule tereti erecto, foliis ovatis fubpubefcentibus. $S p \cdot p l .1105 \cdot$ (Moris. bift. $\int .5 . t$. 6. f. 11. Pet. berb. t. 60.f. 10.)

Hairy St. John's-Wort. Anglis.

In mountainous woods and thickets not uncommon. 4. VII.

The ftalk is hairy. The leaves hairy and perfora. ted, but not dotted on the edges. The flowers grow in a fpike or panicle, much more numerous than in the preceding. Each ferrature of the calyx is tip'd with a gland. The petals have two or three black dots or glandules at the apex. The antbere are without glands. The ftyles are of a red color, turning black by age. The flowers of this fpecies clofe together in the night, but thofe of the $H$. perforatum do not.

elodes 7. HYPERICUM foribus ingynis, caule tereri reE e 2 pente, 
pente, foliifq; villofis fubrotundis. $s p . p l$. 106.

(Pet. berb. t. 6o. f. 12. Mentz. pug. t. 7. f. 3 . an?)

Marih hoary St. Peter's-Wort. Anglis.

In bogs, but not very common. Dr. Parfons. It was obferved in the inand of Ilay, by that celebrated naturalift, Jofeph Banks, Efq; 4. VII. VIII.

The ftalk is five or fix inches long, branched, weak and trailing, and together with the leaves covered with hoary hairs. The leaves when view'd with a microfcope, appear to be finely perforated. The flowers grow in a thin panicle at the top of the ftalks, upon fmooth branched peduncles. The calyces are fmooth, and their fegments edged with very fmall glandules. The bractece are oval, acute, oppofite, and edg'd with the like glandules. The petals are of a pale yellow, and feldom expand, but are commonly twifted together in a direction, from left to right, or with the fun's diurnal motion.

pulcorum 8 HYPERICUM foribus trigynis, calycibus ferratoglandulofis, caule tereti, foliis amplexicaulibus cordatis glabris. Lin. mantifs. fecund. $p .45^{6}$. Sp. pl. 1106. Pet. herb. t. 60.f. 6. Oed. Dan. 6. 75. opt.)

Elegant St. John's Wort. Anglis.

In dry woods and heaths, but not very frequent. 
We obferved it in the little inand of Lamlafs, to the South of Arran. 24. VII.

The ftalks are ereet and fmooth. The leaves are firm, fmooth and gloffy, of a triangular heartfhap'd figure, of a dark green above and glaucous underneath, perforated towards the points, and a little reflex'd or contracted on the edges, but not dotted. The flowers grow in thin fpiked panicles. The fegments of the caly $x$ are oval, finely ferrated, the ferratures tipped with fine black glands. The petals are of a deep yellow, almoft orange-color'd, and commonly dotted on the edges, near the apex with black glandules. The anthera are fcarlet. 
C I $\quad A \quad S \quad S \quad I \quad S \quad X I X$.

S Y N G E N E S I A. POLYGAMIA ÆQUALIS.

* Semiflofculof, f. corollis ligulatis ommibus.

HYPOCHÆRIS. Recept. paleaceum. Pappus fub. plumofus. Cal. imbricatus.

TRAGOPOGON. Recept. nudum. Pappus plimofus. Cal. fimplex.

LEONTODON. Recept. nudum. Pappus plumofus. Cal. imbricatus fquamis laxis.

SONCHUS. Recept. nudum. Pappus pilofus. Cal. imbricatus gibbus.

CREPIS. Recept. nudum, Pappus pilofus. Cal. calyculatus fquamis diffornibus.

PRENANTHES. Recept. nudum. Pappus pilofus. $\mathrm{Cal}$. calyculatus fubquinqueflorus.

LACTUCA. Recept. nudum. Pappus pilofus. Cal. imbricatus margine fcariofo.

HIERACIUM. Recept. nedum. Pappus pilofus. Cal. imbricatus ovatus.

LAPSANA. Liecept. nudum. Pappus nullus. Cel. calyculatus. 
HYOSERIS. Recept. nudum. Pappus non pilofus. Cal. fubaqualis.

\section{* Capitati.}

CARLINA. Calyx radiatus, radiis coloratis.

ARCTIUM. Calyx fquamis apice incurvato-hamofis!

CARDUUS. Calyx fquamis fpinofis ventricofus. Recept. pilofum.

ONOPORDUM. Calyx fquamis ventricofus fpinofis. Recept. favofum.

SERRATULA. Calyx fquamis acutiufculis muticis imbricatus, fubcylindricus.

$$
\text { *** Difcoidea. }
$$

EUPATORIUM, Recept. nudum. Pappus. plumofus. Cal. imbricatus. Piftilla longiffia.

BIDENS. Recept. paleaceum. Pappus ariftatus. Cal, imbricatus.

\section{* Tanacetum.}

\section{POLYGAMIA SUPERFLUA.}

\section{* Discoidea.}

ARTEMISIA. Recept. fubnudum. Pappus nullus. Corol. radii nulli.

TANACETUM. Recept. nudum. Pappus fubmarginatus. Corol. radii trifidi.

CONYZA. Recept. nudum. Pappus pilofus, Coror. radii trifidi. 
GNAPHALIUM. Recept. nudum. Pappus plumofus.

\section{** Radiati.}

BELLIS. Recept. nudum. Pappus nullus. Cal. fquamis æqualibus fimplex.

MATRICARIA. Recept. nudum. Pappus nullus. Cal. fquamis imbricatus acutis.

CHRYSANTHEMUM. Recept. nudum. Pappus nullus. Cal. fquamis intimis membranaceis.

DORONICUM. Recept. nudum. Pappus pilofus. Pappus radii nullus.

INULA. Recept. nudum. Pappus pilofus. Anthere bafi bifetæ.

ERIGEROǸ. Recept. nudum. Pappus pilofus. Corol. radii capillares.

SOLIDAGO. Recept. nudum. Pappus pilofus. Corol. radii fubfeni remoti.

SENECIO. Recept. nudum. Pappus pilofus. Cal. fquamis apice fphacelatis.

TUSSILAGO. Recept. nudum. Pappus pilofus. Cal. fquanis fubmembranaceis.

ASTER. Recept. nudum. Pappus pilofus. Cal. fubfquarrofus.

ANTHEMIS. Recept. paleaceum. Pappus nullus. Cal. hæmifphœricus.

ACHILLEA. Recept. paleaceum. Pappus nullus. Radius fub-5-florus. Cal. oblongus.

POLYGAMIA FRUSTRANEA.

CENTAUREA. 
CENTAUREA. Recept. fetofum. Pappus pilofus. Radius corollæ tubulofus.

\section{POLYGAMIA NECESSARIA.}

FILAGO. Recept. nudum. Pappus nullus. MONOGAMIA.

JASIONE. Cal. communis. Cor. 5-petala regularis. Caps. infera, 2-locularis.

LOBELIA. Cal. 5-dentatus. Cor. monopetala irregularis. Caps. infera 2-locularis.

VIOLA. Cal. 5-phyllus. Cor. 5-petala irregularis. Caps. fupera, 3-valvis. 
426 SYNGENESIA : POLYGAMIA ÆQUALIS.

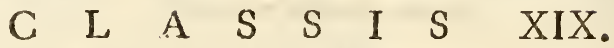 \\ S Y N G E N E S I A.} POLYGAMIA EQUALIS.

* Semifofculofi, $\int$. corollis ligulatis omnibus. TRAGOPOGON. Gen.pl. 905 .

Receptaculum nudum. Calyx fimplex. Pappus plumofus.

pratense I. TRAGOPOGON calycibus corollæ radium æquantibus, foliis integris ftrictis. $S p . p l$. 1109. (Ger. em. 735, f. 2. Moris. bift. S. 7. t. 9. fig. prima ordinis Juperioris. Pet. berb.t. 15. f. 7.)

Yeliow Goat's Reard. Anglis.

In meadows and paftures, Dr. Parjons. ¿. VII.

The root is tap-Shap'd. The ftalk a cubit high and branched. The leaves grafs-like, theathing the ftalk at the bafe, undulated on the edges, and carinated or keel'd on the under fide. The caly $x$ is divided to the bafe into 8 , and fometimes 12 lanceolate fegments. Each branch is terminated with a yellow flower. The feeds are angular and tranfverfely ftriated, crown'd with a pappus or down, which down ftands on a long pedicle, and confifts of about 32 plumofe rays, horizontally 
horizontally expanded. The whole plant is re. plete with a milky juice.

If the weather be fair the flowers of this plant open at the rifing of the fun, and clofe again between nine and ten o'clock in the morning. They ripen their feeds in three weeks from the firft expanfion.

The roots are efculent, being boil'd and ferv'd up to table in the manner of afparagus. The fpring fhoots are alfo eaten by fome in the fame manner. But that which is cultivated in gardens for culinary purpofes is generally another fpecies, the TRAGOPOGON porrifolium Lin. commonly called by the gardeners Salfafy.

\section{SONCHUS. Gen. pl. 908.}

Recept. nudum. Cal. imbricatus, ventricofus. Pappus pilofus.

arvenfis I. SONCHUS pedunculis calycibufque hifpidis fubumbellatis, foliis runcinatis bafi cordatis, $S p . p l$. 1116. (Ger. em. 295. f. 8. Pet. berb. t. 14. f. 6. Moris. bift. f. 7.t. 6.f. 12.)

Corn Sow-Thille. Anglis.

In corn fields frequent. 4 . VIII.

The root creeps under ground, and propagates apace,

The ftalk is three or four feet high, and branched at the top. The leaves are firm and Atiff, embracing the ftalk at the bafe; the middle rib on the under fide foliaceous, and armed with foft prickly

ferratures. 
428 SYNGENESIA : POLYGAMIA ÆQUALIS.

ferratures. The figure of thofe leaves is various. Sometimes they are intire, or only indented on the edges. Sometimes they have one pair of fagittate or cordate pinnes at the bafe. At otber times they are pinnated half-way down to the rib, with triangular reverfed pinna, the extreme one being largett, and all of them edged with foft fpinule. The peduncles and calyces are covered with yellow grofs hairs. The flowers are large and yellow, and turn always towards the fun. The feeds are crown'd with a foft, fimple, feffile down.

oieraceus 2. SONCHUS pedunculis tomentofis, calycibus glabris. Sp. pl. I116. (Ger. em. 2g2. f. 3 E 4. Pet. t. 14.f. 3, 9, 10. Moris. hift. S. 7.t. 3.f. 1 E 2. Blackwell t. 130. opt.)

Common Sow-Thiftle. Anglis.

In wafte places and cultivated grounds frequent. $\odot$. VI-VIII.

The ftalk is fucculent, fiftular, and a cubit high or more. The leaves are tender, of a very variable figure, being fometimes intire, and fometimes jagged or pinnated half way down to the rib; their edges furrounded with foft prickly ferratures. At their bafe they embrace the ftalk, and are prefied clofe to it. The upper leaves are always of an oval-lanceolate figure, and intire; but ferrulated on the edges. The ftalk is branched towards the top, and forms a kind of umbel 
of pale yellow flowers. The central flower which terminates each branch has the fhorteft peduncle. The peduncles are not always downy, but become fmooth as the plant grows old.

ajper.

There is a variety of this plant with more rigid and more prickly leaves, which fome authors make a diftinct fpecies. vid. fig. Jequentes. (Ger. em. 291.f. 1, 2. Pet. berb.t. 14.f. 4, 5, E ejus varietates f. 1, 2, 3. Pluk. alm. t. 61.f. 5. Loes. Prufs. t. 77 E 78 . Moris. bift. S. 7. t. 2. f 5 . E 8. ordinis inferioris. Blackwell. $t .30$.

This as well as the former varies with intire and laciniated leaves, as appears from the different figures.

The young tender leaves of fow-thiftle are in fome countries boil'd and eaten as greens. They are of a cooling nature, and applied outwardly, by way of cataplafm, have been found ferviceable in inflammatory fwellings and carbuncles Swine, Hares, and rabbits are fond of them.

The flowers open about fix or feven o'clock in the morning, and thut up again at eleven or twelve.

\section{LACTUCA. Gen. pl. gog.}

Receptaculum nudum. Cal. imbricatus, cylindricus, margine membranaceo. Pappus fimplex ftipitatus.

virofa I, LACTUCA foliis horizontalibus, carina aculeatis dentatis, Sp. pl. 1119. (Ger. eas. 309. f. 1. Pet. 
$43^{\circ}$ SYNGENESIA : POLYGAMIA EQUALIS.

berb.t. 15. f. 1, 2. Moris. bift. f. 7. t. 2. f. 16 . melior.)

Strong-fcented wild Lettuce. Anglis.

On banks and by way-fides, but rare. We obferved it in the park at Edinburgh, at the foot of Artbur's feat. o. VIII.

The ftalk is three or four feet high, fcattered over with a few fpines, and branched. The radical leaves are broad and intire, but thofe on the ftalk are not always fo, being fometimes deeply jagged or pinnated half-way to the rib, and all of them armed with prickly ferratures on the edges. They embrace the ftalk at the bafe, and the rib on the under fide is prickly. The upper leaves alfo embrace the ftalk, but are intire and oval-lanceolate. The calyx and upper part of the ftalk is vifcid. The flowers yellow. The feeds have a fharp prickly apex, are mark'd with tuberculous ftreaks above their middle part, and are crown'd with a foft fimple down, ftanding on a fine flender pedicle.

The whole plant is full of a bitter milky juice, which, when dry, is inflammable, and not inferior to opium in its virtues, The leaves are narcotic, and if eaten will intoxicate, which has occafioned it to be called poifonous, and men have from thence been frighted from the ufe of it; but it is a very gentle and fafe opiate. The beft way of giving it is in a fyrrup made from a deccesion of the fren leaves and ftalk. In 
this way it is faid to be much preferable to the common diacodium, and may given to tender conftitutions with more fafety.

\section{PRENANTHES. Gen. pl. gri.}

Recept. nudum. Cal. calyculatus. Pappus fimplex, fubreffilis. Flofculi fimplici ferie.

muralis I. PRENANTHES fofculis quinis, foliis runcinatis. Sp. pl. I1 2 I. (Ger. em. 293.f. 5. Pet. berb. t. I5. f. 5. Oed. Dan. t. 509. opt.)

Wall Lettuce, Ivy-leav'd wild Lettuce. Anglis. On thady rocks, and on the walls of old caftles in the lowlands. 2 . VII.

The ftalk is two or three feet high, and greatly branch'd at the top. The leaves have one or two pair of haftate reverfed pinna, with a very large triangular one at the end, nightly divided into three acute lobes, which are dented on the edges. They embrace the ftalk at the bafe, and the middle rib on the under fide is acute and ferrated. The uppermoft leaves are lanceolate. The branches are naked, and form a lax panicle of numerous fmall yellow pendulous flowers. The calyx confifts of five fcales, with four fmaller fupplementary ones at the bafe. The flower has only five ligulated florets, which are truncated and have four dents. The feeds are black, ftreaked, of an oval-acute figure, and crown'd with a fimple down, which ftands on a hort pedicle.

LEONTODON. 


\section{LEONTODON. Gen. pl. 912.}

Recept. nudum. Cal. imbricatus fquamis laxiufculis. Pappus plumofus.

taraxacusn

I.
LEONTODON calyce fquamis infernè reflexis, foliis runcinatis denticulatis lævibus. Lin. $\int y / t$. nat. p. 521 . Sp. pl. I122. (Ger. em. 2go.f. I. Pet. berb. t. п1.f. 7, 8. Moris. bift. S. 7. t. 8.f. I. ordinis medii. Blackwell t. 501. bona.)

Dandelion. Anglis.

Am bearnan-brìde. Gaulis.

In meadows and paftures common. 4. V. VI.

The floral ftalks are fmooth, tender, fucculent, fiftular, and bear each a fingle yellow flower. The fcales of the calyx are fmooth, the exterior and lowermoft ones reflexed. The feeds are acutely elliptical, rough, and crown'd wirh a fimple down, fupported on a pedicle, and therefore has not properly the characters of this genus.

goludofum. It varies In marhy grounds with leaves intire, or only indented on the edges, which fome authors make a diftinet fpecies. (vid. Scopoli Flor. Carniol. n. 958 t. 48.)

This we obferv'd on the fides of the mountains in ine of Skje, in moift places.

The plant has a bitter milky juice, and a reinarkable diuretic quality.

The young leaves in the fpring, when blanch'd and tenter, are admired by many as a fallad. They 
SYNGENESIA : POLYGAMIA RQUALIS. 433 are recommended thus taken for the jaundice and cachexy, and in a ftrong decoction for the gravel.

autumnale LEONTODON caule ramofo, pedunculis fqua2. . mofis, foliis lanceolatis dentatis integerrimis glabris. Sp. pl. 1123 . (Ger. em. 296.f. 2. Pet. berb. t. 12.f. 3. 4. Moris. bift. f. 7. t. 7. f. 6. ordinis inferioris.)

Yellow Devil's-Bit. Anglis.

In meadows and paftures frequent. 2 . VIII.

The root is hort, thick, truncated and crown'd with fibres. The ftalks naked and branch'd. The radical leaves numerous, fmooth, of a variable figure, commonly deeply indented, or laciniated half-way down to the rib, the lacinie acute and intire. Sometimes they are almoft intire, being only nightly dented. The ftalk is tumid under the flower. The calyx fmooth; the flowers yellow. The feed longin, and crown'd with a plumofe fefile down.

The flower opens about feven o'clock in the morning, and clofes at three in the afternoon.

bifsiduin 3 LEONTODON calyce toto erecto, foliis, dentatis integerrimis hifpidis, fetis furcatis. Lin. fyft. nat. p. 522. Sp. pl. 1124 . (Ger. emac. 303.f. 6. Pet. berb.t. 11.f.9, 10. Moris. bift. f. 7. t. 8. fig. ult. ordinis medii ad dextrans.)

Rough Dandelion. Anglis.

In meadows and paftures frequent. 2 . VI.

$F f$

The 
434 SYNGENESIA : PCEYGAMIA IEQUALIS.

The radical leaves are numerous, rough, cry and faplefs, lanceolate, and either fparingly indented, or more commonly laciniated half way to the rib: the lacinic acute, and growing larger by degrees towards the end of the leaf, which is terminated with a triangular one. Thefe leaves are covered with white rigid hairs, which are bifid and trifid at the top. 'T he ford ftalks are firm, hairv, deftitute of leaves, eight or ten inches high, and terminated each with a fingle yellow flower. The calyx is hairy. The exterior forets greenifh or olive-color'd on the under fide. The feeds are longer than the down and ftriated: the down is plumofe and ftands on a fhort pedicle.

That variety with leaves almoft entire, or only fparingly indented, grow in dry mountainous and Itony places.

The flowers generally open about four o'clock in the morning, and thut up at three in the afternoon.

\section{HIERACIUM. Gen. pl. 913.}

Recept. nudum. Cal. imbricatus, ovatus. Pappus fimplex, feftilis.

* Scapo nudo unifloro.

alpinum I HERACIUM foliis oblongis integris dentatis, fcapo fubnudo unitloro, calyce pilofo. Sp.pl. 1124. Raj. synop. p. 16g. t. 6. f. 2. Mioris. hifi. . 7.t. 7.f. 5. bona. Pet. berb. t. 11.f. 2 E fig. nolt.) Alpine Hawkwecd. Anglis. 


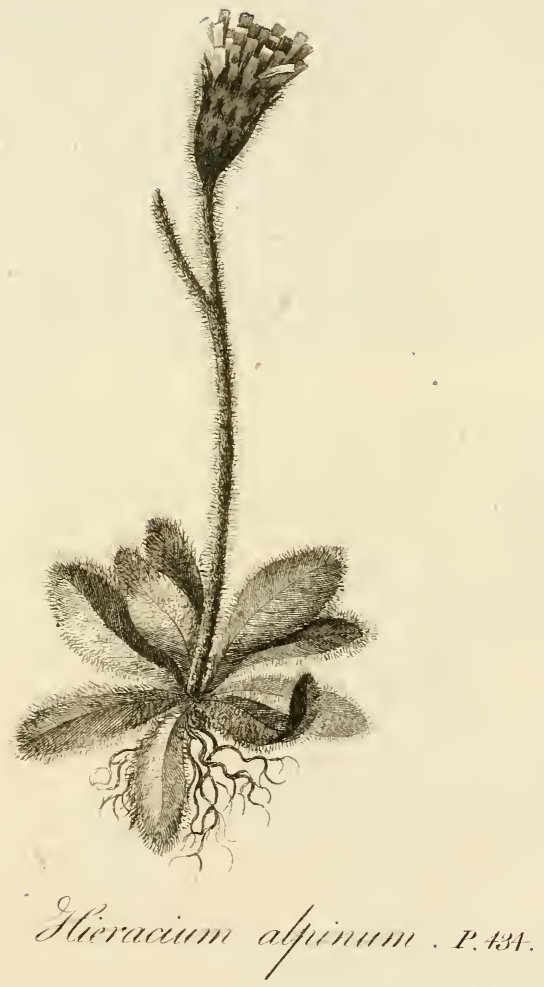

cieffither tet. 

In dry foil near the fumnits of the highland mountains in many places, as upon Ben-mor, and upon Craig-vore, juft above Loch-Laraig-an-Locbain, both mountains in Breadaibane. Upon Corryyaal, and near the top of Bedan-nam-bian, the the higheft mountain in Glenco, in upper Lorn, being, according to the obfervations of the ingenious Mr. Stuart, 3150 feet above the level of the fea. We obferv'd this plant likewife upon the high mountains to the fouth of Little Loch Broom, in Rosfire, upon the weftern coaft; as alfo on Ben-na-grion, two miles above M'Kinnon's caftle in Strath, in the ine of Skye, fo that it is not a farce plant upon the Britifh Alps. 24. VII. VIII.

The radical leaves vary in figure, fome of them are oval-obtufe, others oval-lanceolate, often entire on the edges, but fometimes nightly dented, and always fprinkled on both fides with white woolly hairs: the ftalk is generally about five inches high, fcattered with white hairs, which are fufcous at the bafe, either quite deftitute of leaves, or furnifhed only with one fmall narrow lanceolate rudiment or bractea near the top, and bears a fingle yellow flower : the caly $x$ is black and covered with white hairs: the feeds are oblong, brown, angular, and crown'd with a fimply-hairy feffile down.

araxaci 2. HIERACIUM foliis lanceolatis dentatis glabris; Ff 2 
$43^{6}$ SYNGENESIA: POLYGAMIA EQUALIS.

fcapo fubnudo unifloro, calyce hirfuto. $s p$. pl.

1125. (Fig. nulla fidenda.)

Hawkweed, with yellow Devil's-bit leaves. Anglis.

In wet ground on the fides of the highland mountains, but not conmon. We gathered it on the fide of a mountain call'd Ben-na-Caillich, in the parifh of Cbrift's-Cluurch, in Stratb-Swardie, in the ille of Skye. थ. VII.

The radical leaves are fmooth, narrow, lanceolate, diftantly dented on the edges, and fonetimes pinnatifid or jagged half way to the rib : they have long red foottlalks, and the middle rib is reddifh: the ftalk is fix inches high, fmooth towards the bafe, but hairy at the top near the flower, deftitute of leaves, except three or four minute ru. diments or brakice towards the upper Parts, and bears a fingle yellow flower: the calyx is black and covered with fufcous hairs, and the top of the ftalk juft under it is tumid: the feeds are crown'd with a feffile plumole down, which laft character does not telong to this genus, and there. fore Haller has placed it under his genus of $\mathrm{PI}_{\mathrm{I}}$. CRIs. Hift. Heivet. \#. 27.

pilofella 3. HIERACIUM foliis integerrimis ovatis fubtus to. mentofis, ftolonibus repentibus, fcapo uniforo Lin. fys. nat.p. 522. Sp. pl.1125. (Ger. em. 638 f. 2. Pet. herb. t. 11. f. 1. Moris, biff. f. 7.t.8 fig. due prime ordinis fuperioris. Blackwell. t. 365 Moufe-ear Hawkweed. Anglis. 
In dry barren paftures common. 4 . VI.

The calyx of this kind is black and hairy: the flower fulphur-color'd, the exterior florets sed on the under fide. It opens at eight o'clock in the morning, and clofes at two in the afternoon....-The infect called by Linnous Caccus Pilogella adheres to the roots of this plant.

\section{** Caule folioso multifloro.}

yurorum $4 \mathrm{H}$. caule ramofo; foliis radicalibuís ovatis dentatis, caulino minori. Sp. pl. 1128. (Ger. em. 304. f. I, 2. Pet. berb. t. 13. f. 2, 3, 4, 5. F. Baub. II, p. I034. bene. Moris. bift. f. 7.t. 5.f. 54) Wall Hawkweed, French Lungwort. Anglis.

In woods and on walls and rocks frequent. 4 . VII. This plant varies exceedingly, as appears from the different figures which are given of it. Its general appearance is as follows: The root produces one flender ftalk, a foot high, fcatter'd with hairs, having one lateral branch, and producing but few flowers : the leaves are chiefly radical, of an ovalacute form, dented on the edges particularly at the bafe, are fcattered with a few hairs, are red. difh underneath, and ftand on foot-ftalks. The ftalk has commonly one or two leaves towards its bafe like the preceding, only fmaller, and fupported alfo by a footftalk: the branches are are long, naked, bearing each two or three yellow flowers: the calyx is blackifh, covered with flifcous hairs : the feeds black and furrow'd: from $\mathrm{F} \mathrm{f}_{3}$ the 
$43^{3}$ SYNGENESIA : POLYGAMIA $\#$ EQUALIS.

the firft expanfion of the flower to the ropening of the feeds is about 18 days.

It varies $\mathrm{r}$. with leaves fprinkled with white fpots.

2. with narrower and more lanceolate leaves.

3. with radical leaves roundifh.

4. with leaves pinnatifid at the bafe.

5. with naked unbranched ftalks, bearing two, and fometimes only one fingle flower...-This laft is frequent upon the highland mountains in dry rocky places. vid. Pet. berb. $t$. I1. $f .4$.

paludofum HIERACIUM caule paniculato, foliis amplexicau5.

libus dentatis glabris, calycious hifpidis. Sp. pl. 112. (Ger. em. 300. f. 11. bona. Moris. bift. S. 7 . t. 5.f. 47. Pet. berb. t. 1. . f. g. Gmelin. Fl. Siber. II. t. 9. Sed vit:oje, quoniam folia E' caulis birfuta) Marth Hawkweed. An lis.

By the fides of rivers in rocky places, both in the highlands and lowlands, frequent. 24 ? VII. VIII. The ftalk is two feet high, fmooth, and branched into a thin panicle at top: the leaves are ovallanceolate, fmooth and tender, fharply dented on the edges, the dents revers'd: the radical ones which are four or five, have foliaceous dented footftalks: thofe on the ftalk, which are commonly about three, diftant from each other, are feftile and embrace the ftalk at their bafe : the panicle confilts only of about five or fix yellow flowers, one, two or three upon a branch : the calyces are livid and cover'd with black hairs. 
SYNGENESIA : POLYGAMIA FQUALIS. 439

The flowers are open from fix o'clock in the morning till five in the afternoon.

Iuboudum6. H. caule erecto multiforo, folits ovato-lanceolatis dentatis femiamplexicaulibus. Sp.pl. 11 3 1 . (Fet. kerb. t. 13.f. 7. Moris. bift. .. 7. t. 5. f. 59. Gmelin. Fl. Sibir. II. n. 30. t. 14.)

Broad-leav'd Bulhy Hawkweed: Anglis.

In woods and rough ftoney places, but not ver? common. 4 VII. VIII.

The ftalk is a yard high, hairy; fiff, and branched at the top into a thin panicle: the leaves are hairy and remotely dented: thofe on the ftalk are numerous, often crouded together in one part, and fometimes intire on the edges: the flowers are yellow, and grow on hairy peduncles, furnifhed with lanceolate brantere: the calyx is livid, a little hairy, and fometimes fmooth : the receptacle or bed upon which the florets are difpofed is a little rough and hairy: the feeds when ripe are black, ftriated and quadrangular.

It varies fometimes with roundinh leaves; and at othertimes with leares almoft fmooth.

imbellatum HIERACIUM folnis linearibus fubdentatis fparfis, 7 . foribus fubumbellatis. $S p$. pl. II 3 I. (Ger. ein. 298.f. 5. Pet. herb. t. 13.f. 1 1. Meris. hift. S. 7 . t. 5.f. 66.)

Narrow leav'd Burhy Hawkweed. Ainglis.

In rough ftoney places, but not very common. We obferved 
obferved it about the king's feat at Dunkeld, \&c. 4. VIII.

The ftalk is a yard high, erect and firm, and terminated with an umbel of yellow flowers: the leaves on the ftalk are numerous, diftant from each other, fmooth, of a narrow elliptic form, dented on the edges, and fometimes intire : the peduncles are furnifhed with braitee: the calyx is fmooth and of a livid color: the receptacle is rough, and pierced deeply with little cells.

There is a variety of this fometimes found with narrow grafs-like leaves. (vid. Pet. berb.t. 13.f. 12. And alfo another variety with a ftalk not above 9 inches high, bearing often only a fingle flower, the leaves nearly oval and intire, and rough on the edges. (Dillcn. Eph. Nat. Cur. Cent. V. VI. Append.p. 36. tab. 13.f. 1. Vaillant. 48.)

This Mr. Stuart obferv'd about Locb-Rannoch, in Perthpire.

Thefe are ufed in Sweden to dye yarn of a fine yellow color.

\section{CREPIS. Gen. pl. 9 I 4 .}

Resept. nudum. Cal. calyculatus fquamis deciduis. $P$ appus plumofus, ftipitatus.

¿eforum $\mathrm{x}$. CREPIS foliis lanceolato-runcinatis feffilibus lavibus, inferioribus dentatis. Lin. Jyft. nat. p. $5^{25}$. Sp. pl. 1135. (Ger. em. 297. f. 4. Moris. bift. S. 7.t. 7.f. 29. Pet. berb. t. 12. f.6, 7. EJ ejus varietas t. $12 . f .3,4,5$.) Smooth Succory Hawkweed. Anglis. 


\section{SYNGENESIA : POLYGAMIA ÆQUALIS. 441}

In meadows, paftures, and upon thatch'd and turfed cottages. $\odot$. VII-IX.

The ftalk varies from one to three feet high, firm, and roundifh at the bafe, but ftriated or furrow'd upwards: the leaves are generally fmooth, but are fometimes rough, with bifid hairs : the radical leaves are pinnatifid, the fegments acute, often revers'd, their fegments at the bafe the longeft; thofe on the branches entire, linear, pointed at the bafe, and the edges reflex'd: the branches arife from the bofoms of the leaves: the flowers are yellow, and grow in loofe clufters at the top of the branches: the fcales of the principal calyx are 12 or 13 , erect, furrow'd, and fcattered with glutinous hairs: the fcales of the inferior fupplementary calyx are only about five: the ftyles are fufcous and are protruded without the antbere: the down is plumofe, and in this fpecies, contrary to one of the characters of the genus, is feffile.

It is a very variable plant.

Sometimes the leaves are only dented on the edges, not jagged, as reprefented in Petiver's figure, $t$. 12. $f \cdot 5$.

Sometimes it is dwarfinh, and the ftalk has no leaves, but only narrow fipula. Pet. berb. t. I 2 . $f \cdot 3,4$.

HYOSERIS. Gen. pl. gi6. Recept. nudum. Cal. fubæqualis. Pappus pilofus vel obfoletus. 


\section{SYNGENESIA : POLYGAMIA EQUALIS.}

minima I. HYOSERIS caule divifo nudo, pedunculis incraffatis. Sp. pl. 1138 . (Ger. em. 2 18. f. 8. Pet. berb. t. 15.f. 9. Moris.bift. J. 7. t. 1.f. 8. Oeder. Dan. t. 201. opt.)

Small Swine's Succory. Anglis.

In corn fields in a gravelly or fandy foil, but rare. Sibbald. $\odot$.VI.

The whole plant is fmooth, erect, and about fix or eight inches high : the radical leaves are numerous, oval, acutely dented, and fpread upon the ground round the root: the ftalks are red, and wiry at the bafe, but green, fiftular, and tumid by degrees to the top: they are deftitute of leaves, and generally divided towards the top, bearing each two or three yellow flowers: the in. terior fcales of the calyx are equal and acute; the exterior fupplementary ones are flender, dry, and form only one row or circle the florets are truncated, and have commonly five dents : the feeds are fhort and ftriated, nearly oval, and crown'd with a very hort margin.

\section{HYPOCHZEIS. Gcn. pl. 918.}

Recept. paleaceum. Cal. fubimbricatus. 'Pappus plumofus.

glabra I.

HYPOCHÆRIS glabra, calycibus oblongis imbricatis, caule ramofo nudo, foliis dentato-finuatis. ip. pl. si 40. (Oed. Dan. t. 424. opt. Moris. bift. f. $7 . t \cdot 4 \cdot f \cdot 35$.)

Smooth Hawlisweed. Anglis. 
In mountainous paftures and gravelly foils, but not common. $\odot . s$. $\delta$ ? VII. VIII.

The ftalk is 12 or 18 inches high, and branched: the radical leaves are of a long elliptic form, acute at the end, and finuated or deeply indented on the edges, the dents acute; they are not al. ways fmooth, but fometimes a little hairy: the ftalk-leaves are minute, fefrile, oval-lanceolate, the lower ones fightly dented, the upper ones entire, and refembling fitpule: the peduncles are thickeft at the top juft under the flowers: the fcales of the caly'x are fmooth, and very diftinet: the flowers yellow, and about hait an inch in diameter: the down of the feeds, which are placed in the centre of the dife, is fupported on pedicles, but of thofe in the margin is feffile.

radicata 2. HYPOCHFRIS foliis runcinatis obtufis fcabris, caule ramó́o nudo lavi, pedunculis fquamofis. sp.pl. 1140. (Ger.em. 29", f. 6. Moris. bift.f. 7.t. 4.f. 27. Oed. Dan. t. 150.)

Long-rooted Hawkweed. Anglis.

In meadows and paftures frequent. 2 . VII.

The root is long, thick and white: the radical leaves are hairy and roughin, and lie prontrate on the ground round the root: they are jagged half way to the rib, the anterior lacinia being broadelt, and the extremity of the leaf obture : the falks are naked, (except a few fmall ovalacute Aipula) fmooth, tough and pliant, branched, 12 or 15 inches high, and thickeft at top juit under 
444 SYNGENESIA : POLYGAMIA EQUALIS.

under the flowers : the interior fales of the calyx and thofe of the bafe are fmooth, the others have their carina near the apex ciliated with white hairs: the flowers are yellow, and above an inch in cliameter, the marginal forets reddifh or livid underneath : the feeds are narrow, elliptical, reddifh and ftreak'd, the ftrealis above the middle part denticulated : the down confints of about 30 pulmofe rays ftanding on a pedicle as long as the rays, but fhorter than the palea, or thofe chafry fubftances which are placed amongft the florets upon the receptacle.

The plant yields a bitter milky juice, fmelling like opium.

The flowers clofe up at three o'clock in the afternoon.

\section{LAPSANA. Gen.pl. gig.}

Recept. nudum. Calyx calyculatus, fquamis fingulis interioribus caniculatis. Pappus nullus.

comunis I LAPSANA calycibus fructus angulatis, pedunculis tenuibus ramofifimis. Sp. pl. $114 \mathrm{I}$. (Ger. em. 255. Pet. berb.t. 14.f. 12. Moris. hift. . 7.t. 1.f.g. Oed. Dant. t. 500. opt.)

Nipplewort. Anglis.

In cultivated grounds and wafte places frequent. ๑. VII. VII.

The ftalk is eref, from two to flve feet high, and branched: the lower leaves are pinnatifid, having commonly two imall finnu're upon the footftalk, 
ftalk, and one large oval finuated one terminating the leaf: the upper ones are feffile, acutely oval and dented: the branches are almoft naked, and form a kind of loofe open panicle of yellow flowers : the calyx is fmooth and confints of 8 fcales, growing together in a furrow'd cylinder, with five other unequal fupplementary ones at the bafe: the flowrets are from 18 to 22 in each flower: the calyces become angular as the feeds ripen: the feeds are ftriated, a litcle gibbous and deftitute of down.

The young leaves in the fpring have the tafte of radifhes, and are eaten by the inhabitants of Confrontinople raw as a fallad. In fome parts of England the common people boil them as greens, but they have a bitter and not agreeable tafte.

* Capitati, flofculis omnibus tubulofis bermaploroditis.

\section{ARCTIUM. Gen. pl. 923.}

Cal. globofus; fquamis apice hamis inflex:s.

lappa 2. ARCTIUM foliis cordatis inermibus petiolatis. Sp.pl. 1143 . (Ger. em. Sog.f. 1. Pet. berb. t. 32 . f. 1, 2, 3, 4, 5, 6. Moris. bijt. .. 7.t. 32.f. 1.2. Blackwell. t. 117. Miller. ic. 159.)

Burdock. Anglis.

Mac-an-dogha, Suircean fuirich. Gaulis.

In wafte places by way-fides, and in paftures at the foot of mountains frequent. $\sigma$. VII. VIII.

The root is long, fimple, ftrait and thick: the leaves are very large, heart fhap'd, obtufe, wooly underneath, 
446 SYNGENESIA: POLYGAMIA ZEQUALIS.

underneath, and rightly dented on the edges : the ftalk is two or three feet high and branch'd: the flowers are purple and grow in fphærical heads, forming a kind of clufter'd umbel: the colyces are fometimes fmooth, and fometimes interwoven with a vooly or cobweb kind of matter: the fcales are hooked at the end, and readily adhere to any thing they touch : the florets are all tubular, hermaphrodite, and have five dents in the rim: the receptacle upon which the florets are difpos'd is cover'd with briftly poiee : the feeds are crown'd with a fhort brittle down, which thro' a microfcope appears to be piumofe.

This plant, tho' generally neglected, is capable of being apply'd to many ufes,---- the root and ftalks are efculent and nutritive: the ftalks for this purpofe fhould be cut before the plant flowers, the rind peel'd off, and then boil'd and ferv'd up in the manner of cardoons, or eaten raw as a fallad with oil and vinegar.

It is likewife us'd in medicine : the great Boerbave recommends a decoction of it in pleurifies, peripneumonies, and malignant fevers. In the fame manner is is faid to have cur'd the venereal difeafe. An elixir of it has been alfo much extoll'd for the crout; and an emulfion of the feeds has a powerful diuretic quality. Outwardly apply'd the leaves have been found ferviceable in headachs, the gout, and odematous fwellings.

Cattle refufe to eat it: but theep propagate it by conveying 
SYNGENESIA : POLYGAMIA REQUALIS.

conveying the feeds from place to place in their wool.

SERRATULA. Gen. pl. 924 .

Cal. fubcylindricus, imbricatus, muticus.

tinstoria I. SERRATULA foliis lyrato-pinnatifidis; pinna terminali maxima, flofculis conformibus. $s p . p l$. 1144. (Ger. ein. 713.f. 2. Pet. berb. t. 22.f.5.6. Oed. Don. t. 28 I.)

Saw-wort. Anglis.

In woods and wet paftures, but not common. 4. VII. VIII.

The ftalk is ftiff, angular, branch'd and a yard high : the leaves are firm, fmooth and finely ferrated on the edges: the lower leaves are fometimes oval and intire, fometimes pinnatifid at the bafe only; at other times they, together with thofe on the Italk, are all pinnatifid throughout, with oval lanceolate pinnule: the flowers are purple, and grow in a kind of cluftered umbel at the top of the ftalk: the calyces are nearly cylindrical, the fcales erect, acutely oval, clofely compacted, and and a little wooly on the edges: the receptacle has rigid hairs : the feeds are crown'd with a feffile fhining, fimple down, of a golden fufcous color.

It dyes cloth of an exceeding fine yellow color, preferable to the LUTEOLA or Genista; and the color ftands well when fix'd with alum.

Cattle are obferv'd to leave this plant untoush'd.

S. calycibus 
448 SYNGENESIA : POLYGAMIA EQUALIS.

alpina 2. S. calycibus fubhirfutis ovatis, foliis indivifis. Sp. pl. 1145. (Pluk. alm. t. 154.f. 3. Gmelin. Fl. Sibir. 2.p 67. t. 26. Ger. em. 1184. f. 7. Moris. bift. f. 7.t. 29. f. r. Oed. Dan.t. 37. var, foliis lanceolatis anguftis.)

Alpine Saw-wort. Alpine foft Thittle. Anglis.

It grows on the fides of the highland mountains in many places, as among the rocks on the eaftern fide of Mal-gbyrdy, and near the top of Bercruipen, in Breadalbane; on the north fide of Stuic-an-locbain, in Glen-lyon; upon Ben-acbalader, and Ben-dotba, in Glenorchy; and upon Malmore, a mountain in Glence, in Upper-Lorn, about two thirds of the way? " We found it alfo upon a Brae, a mile from Talikar, in the ine of skye, between the two rocks called Great and Little Breeze-Hill. We are informed that it has been gathered likewife in the lowlands near Moffat, in Amandale, fo that it is not a very fcarce plant in Nortb-Britain. 24. VIII. IX.

It is commonly about 10 or 12 inches high, but varies from fix inches to two feet: the leaves are ufually of an oval lanceolate figure, fparingly dented, or nightly finuated on the edges, and woolly underneath; but thefe again vary very much, heing fometimes nearly heart-hhap'd, and at other times of a narrow lanceolate form: the Italk is firm, unbranch'd, woolly and reddin : the flowers are purple and grow in a clufter at the top, with one or two at a little diftance below: the calyx when mature is cylindrical: the fcales

are 


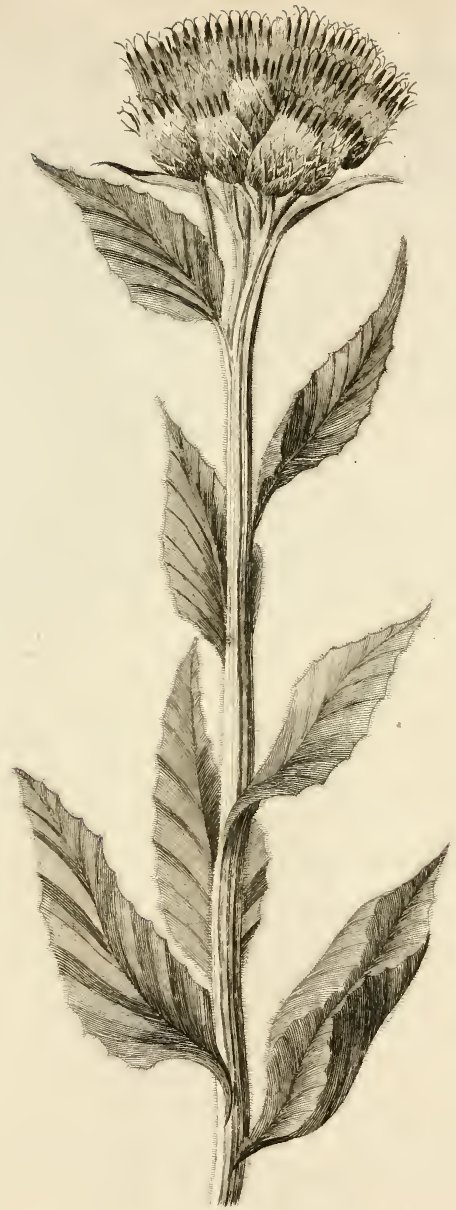

Grepish. Tdet.

- Pervatreler alfuina. P.448. 

SYNGENESIA : POLYGAMIA EQUALIS. 449 are broad, Thort, nearly triangular and woolly : the receptacle is hairy: the feed is crown'd with a feffile plumofe down.

ervenfis 3. SERRATUL foliis dentatis fpinofis. $s p$. pl. 1I 49. (Ger. em. II 73. f. 4. Column. ecpbras. I. p. 45. t. 45. Moris. bift.. . 7. t. 32. f. 14.)

Common Way-Thifte, or Corn-Thiftle. Anglis. Foghenan, Cluaran. Gaulis.

In cultivated grounds and by way-fides. 4 . VII. The root is long and creeping: the ftalk a yard high, erect, branch'd, fmooth and angular, but not winged: the leaves are generally fmooth, of a lanceolate figure, either indented on the edges, or pinnatifid, the lacinice undulated, angular and dented; the dents ending in fpines: the flowers are commonly purple, but fometimes white, and grow in loofe umbels, one or two upon long woolly peduncles : the calyx is longurh, and confifts of numerous compact lanceolate fcales, which end in a Thort harmlefs fpine: the receptacle has thort fetaceous hairs: the down on the feeds is long and plumofe.

The plant when burnt yields good afhes for glafsmaking.

CARDUUS. Gen. pl. 925.

Gal. ovatus, imbricatus, fquamis fpinofis. Recept. pilofum.

* Foliis decurrentibus.

G $g$

CARDUUS 
450 SYNGENESIA : POLYGAMIA EQUALIS.

?anceolatus I CARDUUS foliis decurrentibus pinnatifidis hifpidis, laciniis divaricatis; calycibus ovatis fpinofis villofis, caule pilofo. $S p$. pl. 1149. (Ger. em. 1174. f. 6. Moris. bift.. . $7 . t .3$ เ.f. 7 . ordinis Juperioris.)

Spear-Thittle. Anglis.

An deilgneach. Gaulis.

By way-fides frequent. $\hat{\sigma}$. VII. VIII.

The ftalk is three or four feet long, arm'd with fhort foliaceous, and harply pricked wings : the leaves are pinnatifid, the lobes bifid, fpear-thap'd, divaricated, or alternately elevated and depreffed above and below the dife, the nerves ending in very tharp and ftrong fpines, the extreme lobe much longer than the reft. They are green and rough on the upper fide, but hoary underneath : the calyces are woolly; the outermoft fcales lanceolate, reflex'd, and terminated with fpines: the innermoft fetaceous, dry and unarm'd: the florets are all tubular and purple: the receptacle hairy and conical: the down plumofe.

nutans 2.

CARDUUS foliis femi-decurrentibus fpinofis, floribus cernuis; fquamis calycinis fupernè patentibus. sp. pl. II50. (Pet. berb. t. 21. f. 1. Hort. Aicbftett. aftiv. ord. xı. t. 2. fig. 2. Moris. bift. f. 7. t. $31 \mathrm{f}$. 6. ordinis Jupcrioris, bona.)

Muth-Thiftle. Anglis.

In wafte places near towns, and in dry paftures anc rough itoney foils. $\delta$. VII. VIII. 
Theftalk is two or three feet high, but little branch'd, befet with prickly wings, hhort, and interrupted, not running all the way from one leaf to another : the leaves are pinnatifid, the nerves hairy, the lobes angular, and arm'd with ftrong tharp fpines. The peduncles are long, and bear each a fingle, large purple, nodding flower, having a ftrong mufky fmell, efpecially in the evening, when the odour is condens'd. 'The fcales of the calyx are commonly of a dull red color, terminated with ftrong fpines, the exterior ones ftanding wide and open, the interior erect: the receptacle is fetaceous : the down long but fimple.

The dry'd flowers of this and the preceding fpecies are ufed in fome countries as a rennet to curdle milk.

Many kinds of Pbalene are fond of the flowers, and hover over them at night.

CARDUUS foliis decurrentibus pinnatifidis margine fpinofis, calycibus aggregatis feffilibus fubcylindricis glabris. (Pet. berb.t. 21.f. 3. Moris. bift. S. 7.t. 3 I. f. 13.)

Grey welted Thiftle. Anglis.

Upon banks and in wafte places near towns and villages. ๑. VI. VII.

The ftalk is a yard high or more, but little branch'd, widely wing'd, the wings finuated and edg'd with prickles: the leaves are pinnatifid, woolly underneath, and flightly fo above, the lobes triangular,

$$
\mathrm{Gg} 2 \text { theit }
$$


their edges angular and prickly : the flowers are of a pale red color, almoft white, are feffile, and grow a few here and there upon the ftalk, but in clufters at the fummit : the calyces are acutely conical before flowering, but cylindrical afterwards: the fcales are lanceolate, quite fmooth, a little reflex'd at the apex, and end with a fpine: the down is feffile, long and fimple.

The CARDUUS acantboides, of Linnaus, is certainly a different plant from that which we have here defcribed, as his specific difference and defcription will by no means accord with ours; but as the fynonyms which he has cited under his $\mathbf{C}$. acantboides, belong to our plant, we have thought proper to retain his trivial nome, and apply a new specific difference.

crifpus 4. CARDUUS foliis decurrentibus finuatis, margine fpinofis; floribus aggregatis terminalibus, fquamis inermibtis fubariftatis patulis. Lin. Jyft. nat. p. 529. Sp.pl. 1150. (Loefel. PruJf. 34. t. 5. Ger. em. $1173 . f$. I.)

Thiftle upon Thifte. Anglis.

By way-fides and in wafte places. $\odot$. VI. VII.

The ftalkis green, three or four feet high, branch'd, brittle, uninterruptedly winged throughout, the wings being crifped or curled: the leaves are foft and woolly underneath with green veins, finuated or pinnatifid on the edges, the lobes angular and prickly: the flowers are commonly purple, and moft of them grow in clufters at 
SYNGENESIA : POLYGAMIA EQUALIS. 453 the top of the ftalk, upoin woolly peduncles: the calyx is about the fize of a hazel-nut: the fcales are acute but not pungent, the inferior ones recurv'd, the others ereet.

pahuftis 5. C. foliis decurrentibus dentatis, margine fpinofis; foribus racemofis erectis pedunculis inermibus. Sp. pl. I151. (Pet. berb. t. 21. f. 4. Moris. bift. S. 7.t. 32. f. 13. Gmelin. Fl. Sibir. II. p. 57. tab. 23. $f$. 2.)

Marfh Thiftle. Anglis.

In moift meadows and thady places. 2. VII.

The ftalk is fix feet high, furrow'd, having very few leaves or branches, but defended every where with numerous foliaceous prickly wings: the leaves which are few, are green, a little downy underneath, pinnatifid, the pinne divided into two hort angular lobes, the nerves ending in long prickles, and the pinne terminating the leaf much longer than the reft : the flowers are purple, and grow in clufters at the fummit of the ftalk upon unarm'd peduncles, which clufters, as they advance to maturity, open and become a lax umbel: the calyces are vifcid, about half an inch long, and one third of an inch thick, and often a little woolly : the fcales are lanceolate, clofely imbricated, fucculent, reddifh, the outermoft recurv'd, patent, and terminated with an innocent fpine, the innermoft pointed, but without a fpine : the receptacle is fetaceous, the down feffile and plumofe. 
454 SYNGENESIA : POLYGAMIA EQUALIS.

The tender ftalk of this and moft of the thiftles are efculent, being firft peel'd and boil'd, In this manner the inhabitants of Smoland in Sweden, as Linnaus informs us, of ten eat them.

$$
\text { ** Foliis Seffilibus. }
$$

marianus 6

CARDUUS folis amplexicaulibus haftato-pinnatifidis fpinofis; calycibus aphyllis, fpinis canaliculatis duplicato-fpinofis. $S p . p l$. 1153. (Ger. emac. I 150. Moris. bift. . . 7. t. 30.f. 1. ordinis medii ad dextram. Blackwell t. 79.)

Milk Thiftle. Anglis.

Upon banks and wafte places about towns and villages, but probably only an outcait of gardens. Upon the caftle rock at Edinburgh. Dr. Parfons. $\odot$. VII.

The leaves are large, fmooth, green, but reticulated with white nerves: ore large erect purple flower terminates each branch: the peduncle is almoft naked for fome diftance under the flower: the fcales of the calyx are terminated with an oval appendage which is edged with fharp fpines, the extreme one of which is longeft and very ftrong and pungent : the down which crowns the feeds is plumofe.

There is a variery of this, the leaves of which are deftitute of white veins.

'The tender leaves ftrip'd of their fpines, are by fome boil'd and eaten as garden-ftuff. 
SYNGENESIA : POLYGAMIA ÆQUALIS. 455

An emulfion of the feeds has fometimes been us' $\mathrm{d}$ to thin the blood, and to cure ftiches and pleurifies, but at prefent is rarely practis'd,

eriopborus

CARDUUS foliis feffilibus bifariam pinnatifidis, laciniis alternis erectis, calycibus globofis villofis. Sp. pl. 1:53. (Ger. em. 1152. f. 6. Pet. berb. $t$. 2I. f. 8. Miller. icon. 293. bona.)

Woolly-headed Thiftle. Anglis.

By the fea fide between Blacknefs and the Queen'sFerry, according to Sibbald? \$s. VII.

The ftalk is four or five feet high, ftrong, rough, furrow'd and branched: the lower leaves which fpread on the ground are often two feet long: they are green and rough on the upper fide, but white and woolly underneath, and have a leafy border running along the middle rib : the fegments of the leaves point alternately upwards and downwards, and are divided into two lobes, the nerve of one of them ending in a ftrong tharp fpine, the other long and lanceolate: the branches are terninated with large fphærical heads of purple flowers: the fcales of the calyx are lanceolate, erect, terminated with a yellow fpine, and are curiouny interwoven with a fine cobweb down: the feeds are white, nearly oval, compreffed, obliquely truncated, and crown'd with a plumore down.

This is one of the moft elegant plants of the ginus. The receptacles are pulpous and efculent, like thofe of the artichoke. 
beterophyllus 8.

CARDUUS foliis amplexicaulibus lanceolatis ciliatis integris laciniatifque, caule fubuniloro, calyce inermi. sp. pl. 1154. (Pet. herb.t. 22. f. 1. Ger. em. $1183 . f .5$. E fig. Cirfii anglici Lobelii. Moris. bift. f. 7. t. 29. f. ${ }_{3}$ E 12 . E fortaffe II) Soft or gentle Thiftle. Anglis.

In low marhy paftures and by the fides of lakes, but not common. We obferv'd it in the illand of IJla. 2. VII.

The root is fibrous, creeping, and fometimes tuberous : the ftalk is erect, from fix to twentyfour inches high, fingle, and covered with white woolly down : the radical leaves are acutely elliptical, about three or four in number, fumetimes intire on the édges, fometimes pinnatufid, particularly near the bafe, with fhort fegments, always white and woolly underneath, and fometimes nightly fo above, and ciliated on the edges with fmall innocent prickles: the ftalk has generally one or two leaves upon it near the root, which embrace it at the bafe, but without auricles : befides theie there is a lanceolate rudimental leaf or bracteas placed about the middle of the ftalk : one large head of purple flowers terminates the ftalk, and fometimes another arifes upon a peduncle a little below it : the head of the flowers is an inch long, and three quarters of an inch wide: the fcales of the calyx are lanceolate, erect, a little woolly, of a dull purple color on the back and at the fummits, pointer, but not pungent: the ftyles are longer than the anthere: the down on the feeds plumofe. 
This is the fame plant with the Circium Anglicum $I$. Raj. Synop.p. 193 and which Mr. Huljon in his Flor. Anglic. has by miftake called CarduUs difjectus. Lin.

belenicides CARDUUS foliis amplexicaulibus lanceolatis den9. tatis; fpinulis inæqualibus ciliatis, caule inermi. sp. pl. 1155. (Clus. bift. 2.p. 148. Cirfium anglicum 2. Ger. em. 118 3. Cirfii anglici alia icon Pennei Miller. ic. 94. Haller, bift. Helv. in. 180.t. 7. opt.) Melancholy Thiftle. Anglis.

Cluas-an-fheidh. Gaulis.

By the fides of rivulets in high ground in Breada:bane, Atbol, and all parts of the inland highlands not unfrequent. We obferv'd it near the foot of Ben-buardal, in the ille of Skye. 4.VII.VIII. The ftalk is five or fix feet high, angular, hollow, a little woolly, hardly at all branched, but fur. nithed with many leaves from the bottom almoft to the top: the radical leaves are of a long elliptic form, and are fupported by footfalks: the ftalk-leaves are feffile and heart hap'd at the bafe, where they embrace the ftalk, but are feven or eight inches long, and lanceolate upwards: they are all intire white and hoary underneath, but green above, finely dented on the edges, and ciliated with harmlefs prickles: the brantee or floral leaves near the fummit of the ftalk are fubulate: the flower is large, erect, purple, and fpecious, an inch and half long, and near two inches in diameter when full blown, and terminates the ftalk: one and fometimes two more Alowers grow below it on long peduncles arifing from 
from the ale of the leaves: the fcales of the calyx are lanceolate, erect, acute, but not pungent, and of a dull purple color: the ftyles are much longer than the antbere; and the down of the feeds is plumofe.

A variety of this fometimes occurs, having leaves near their fummits pinnatifid, as figur'd in $\mathrm{O}_{e}$ der's Fl. Dan. tab 109.

acoulis 10. CARDUUS acaulis calyce glabro, $S p . p l .1_{j} 6$. (Ger. em. 1158.f. 3. Pet. berb.t.21.f.6. Moris. hift. $\left.\int .7 . t .32 . f .22.\right)$

Dwarf Carline Thiftle. Anglis.

In dry paftures, but not common. 2 . VII.

The leaves lie clofe to the ground round the root, fo as to occupy a circle of a foot or more in diameter, upon which fpace no other plants or hesbage can grow. They are therefore very detrimental to paftures. Thefe leaves are pinnatifid, their fegments angular, divided into two or three lobes, which are edged with ftrong ipines one head of purple flowers, and fometimes more, ftands in the centre of the leaves upon a ltalk hardly an inch high: the fcales of the clyxs are fmooth, flat, and acute, but not pungent: the down of the feeds is plumofe, and an inch long; the feeds not above $\mathbf{1}-6$ th of an inch.

ONOPORDUM. Gen. pl. 927. Recefit. favofum. Cal. fquama mucronatr. 
ONOPORDUM calycibus fquaroffis, fquamis pa-

tentibus; foliis ovato-oblongis finuatis. Lin $f y f t$. nat.p. 53 I. Sp. pl. II 8. (Ger. em. I149. f. I. Moris. bift. S. 7. t. 3०. f. 1. Superioris E' medii ordinis. Loes. Fl. PrufJ. p. 26r. icon. 81.)

Cotton Thiftle. Angiis.

In wafte places near towns and villages, as at $W$ eems on the coaft of Fife, and half a mile beyond Prefton-Pans, \&c. ô. VIII.

The ftalk is fix feet high, branched, and wing'd throughout from the bafe to the calyx : the ftalk and leaves are fometimes cover'd all over with a white cotton down, fo as to appear quite hoary; at other times this downy covering is light, and then they put on a pallid green color : the leaves are feffile, decurrent, of an oval-lanceolate form, finuated with triangular dents, each angle ending with a ftrong fpine: the heads of flowers are violet-color'd, and terminate the branches : the fcales of the calyx ftand open, and end in a harp fpine: the receptacle is pierc'd with quadrangular cells, which receive the feeds, crown'd with feffile capillary down.

The receptacles of the flowers, and the tender ftalks peel'd and boild, may be eaten in the fame manner as artichokes and cardoons.

A decoction of the root is reckoned a fpecific in a recent Gonorrbea, according to Scopoli. Flor. Car. niol. 10I3. 


\section{SYNGENESIA : POLYGAMIA ÆQUALIS.}

\section{CARILINA. Gen. pl. 929.}

Cal. radiatus fquamis marginalibus longis, coloratis. vuigaris 1. CARLINA caule multifloro corymbofo floribus terminalibus, calycis radio albo. Lin. fyft. nat. $p$. 532. Sp.pl. I161. (Ger. cm. I159.f. 1.)

Common Carline Thifle. Anglis.

In dry hilly paftures, but not very common. $\delta$. VII.

The ftalk is about a foot high, erect, purple, angular, a little woolly, furnifhed with many leaves, and branched at top: the leaves are woolly un. derneath, and pinnatifid, with fhort angular plaited fegments, terminated with Tharp yellow fpines: the upper leaves at the bafe of the ralyx are lanceolate and dented on the edges, the dents ending each in two rigid fpines: the flowers generally crown the ftalk in an umbel, but fometimes it bears only one or two flowers : the inferior icales of the calyx refemble the upper leaves of the ftalk: the fucceeding ones are edged with branched fpines, purple at the bafe, but yellow at the points : the interior ones are long and lanceolate, dry and fhining, ftraw-color'd on the infide, but fufcous on the outfide at the bafe, and fpread like rays in a circle round the difc: the forets are all hermaphrodite, tubular, divided into 5 dents, and of a dark red or purple color at the rim: the receptacle is befet with fetaceous chaft or fols: the down of the feeds 


\section{SYNGENESIA : POLYGAMIA EQUALIS.}

$46 \mathrm{t}$ is fefile and plumore, and confifts of eleven or twelve branched rays.

The ciry ftalk and calyces of this plant often continue ftanding for a whole year after the feeds have ripen'd, a miterably looking fkeleton! Lin. Fl. Suec.

\section{BIDENS. Gen. pl. 932. \\ Difcoidea.}

Recept. paleaceum. Pappus ariftis ereetis, fcabris. Cal. imbricatus. Cor. rarius flof́culo uno alternè radiante inftruitur.

tripartita I BIDENS foliis trifidis, calycibus fubfoliofis, femi-

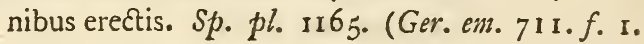
Loes. Fl. PrufJ. p. 53. f. 10. Moris. bift. S. 6. t. 5 . f. 20. Pet. berb. t. 20. f. 7.)

Trifid Water-hemp-agrimony, or Bur-marygold. Anglis.

By the fides of rivulets, ditches and lakes frequent. ๑. VIII.

The ftalk is two feet high, and branched: the leaves are divided into three and often five lanceolate ferrated lobes: the upper leaves are fim: ple and oval-lanceolate: the heads of flowers terminate the branches, and grow erect: under the calys is a circle of green ciliated leaves: the fcales of the calyx are oval, obtufe, erect, of a green color, ftreaked with black, and loofely imbricated: the interior ones have yellow margins, and approach to the nature of the florets: 
462 SYNGENESIA : POLYGAMIA $\mathbb{E} Q$ UALIS.

the florets are yellow and tubular, and are fometimes, but not always, furrounded with femiflor. culous rays : the receptacle has chaffy fcales between the florets : the feeds are flattifh and angular, and have two beards arifing from the angles, which are hooked or barbed downwards, and generally another fhorter heard, which arifes from the middle of the back of the feed.

As this plant is found by a chemical analyfis to poffefs much the fame qualities as the celebrated VERBESINA Acmella, a plant belonging to a genus very nearly related to this, it is probable it would have the lame good effects in expelling the ttone and gravel.

A decoction of this plant with alum dyes yarn with a yellow color. The yarn mut be firft fteep'd in alum-water, then dry'd and it teep'd in a decoction of the plant, and afterwards boil'd in the decoction.

The feeds have been known fometimes to deftroy the CYPRINUS auratus, or gold fifl, by adhering to their gills and jaws.

cernua 2. EIDENS foliis lanceolatis amplexicaulibus, floribus cernuis, feminibus erectis. ip. pl. 1165. (Loes. Fl. Pruf. p. 54. f. I1. Moris. bift. S. 6. t. 5. f. 22. Pet. berb. t. 20.f. 6)

Nodding Water-hemp-agnimony, or Bur-marygold. Anglis. 
In marhy places, and by the fides of lakes. Dr. Parfons. ๑. VIIl.

The whole plant is fmooth, a cubit high, and branched: the leaves are lanceolate, ferrated, oppofite to each other, feffile, and coalefcent at the bafe: the flowers grow fingly at the tops of the branches, and after fhedding their feminal powder, hang down their heads: the lower fcales of the calyx are foliaceous: the flowers are yellow, and fometimes radiated, but not often : the feed is quadrangular, and has four beards, two of which are longer than the others.

minima $\beta$. A fmall variety of this fometimes occurs, from three to fix inches, ,which fome authors have made a diftinct fpecies, becaufe the heads of flowers are erect. But this is not always the cafe, for we have often feen them nod, and are therefore fully perfuaded that it is either an autumnal feedling, produced from an early plant of the preceding, with which it grows promifcuouny, or elfe is rendered dwarfin by fome accidents of growth. (See the figures of it in Lay's synops. p. 188. t. 7.f. 2. EO Oed. Fl. Dail. t. 31 2.)

This has nearly the fame virtues with the preceding, but rather in an inferior degree. It alfo dyes yellow.

\section{EUPATORIUM. Gen. pl. 955 .}

Reciept. nudum. Pappus plumofus. Cal. imbricatus, oblongus. Stylus femibifidus, longus. 
464 SYNGENESIA : POLYGAMIA $\mathbb{E Q U A L I S . ~}$

cannabinum EUPATORIUM foliis digitatis. spz pl. $1173^{\circ}$ I. (Ger. em. 711.f. 2. Moris. bift. .. 7.t. 13. f. 1. Blackwell t. 110.)

Hemp-agrimony, Dutch-agrimony. Anglis.

On the banks of rivers and lakes not unfrequent. In Clifton.Ings, and among the rocks below Kingborne. Dr. Parfons. 4. VIII.

The ftalks are hairy, quadrangular, and from three to fix feet high: the leaves are hairy, oppofite, ternate, the lobes ferrated, the middle one oval-lanceolate, and much larger than the others. In fome the latesal lobes are wanting, or elfe are very fmall. The flowers are of a pale red or purple color, and grow in thick umbels at the top of the branches: the fcales of the calyx are of unequal fize, not above ten in number, and red on the margins : the florets are all hermaphrodite and tubular, longer than the calyx, and five in each: the feed is black, pyramidal, and crown'd with down, which is very Rightly plumofe.

The plant has a very bitter tafte. A decoction of the roots operates as a violent emetic and cathartic, and is fometimes taken by the lower clafs of people to cure the jaundice, dropfy, and cacliexy, but is a rough medicine, and ought to be ufed with caution. 'The great Boerbave made ufe of an infufion of this plant to foment ulcers and putrid fores. Tournefort informs us, that the Turks cure the fcurvy with it. An ounce of the juice, or a dam of the extract is a dofe.

POI.YGAMIA. 
POLYGAMIA SUPERFLUA.

\section{* Difsoidea.}

\section{TANACETUM. Gen. pl. 944.}

Recept. nudum. Pappus fubmarginatus. Cal. imbrivalgare I. Catus, hemifphæricus. Corollule radii obfoletæ, 3 -fidx. TANACETUM foliis bipinnatis incifis ferrratis. sp. pl. 1184. (Ger. ein. 650. f. 1. Pet. berb. t. 20. f. 9. Moris. bift. f. 6. t. I. fig. prima. Gmelis. Fl. Sibir. II. p. 133.t. 65. f. 1. Blackwell. t. 464. optima.)

Common Tanfy. Anglis.

On the borders of fields, and on dry banks, but not very common. We obferv'd plenty of it about $W$ ark and Ford-Cafle, not far from Kelso, on the borders of Scotland, and by the fide of Gare-Lock, on the weftern coaft of Rofs-Bire. Dr. Parfons likewife found it in the den of $B e$ thaick, and Mr. stuart in Breadalbane. 24. VIII. The ftalk is three or four feet high, erect, ftiff and branched. The flowers are yellow, and tefminate the branches in flat umbels: the calyx is imbricated with many compact feries of acute fcales : the compound flower appears to be deftitute of rays, but upon a clofer examination it will be found to have teveral thort female trifid forets in the rim.

It has a bitter tafte, and aromatic fmell. It is efteemed good to warm and ftrengthen the fto- 
mach, for which reafon the young leaves in the fpring have receiv'd a place among the culinary herbs, their juice being an ingredient in puddings, tanfies, and other dainties. It is rarely ufed in medicine, tho' extoll'd as a good emmanagogue. A drachm of the dry'd flowers has been found very beneficial in hyfterics arifing from fuppreffions. The feeds and leaves were formerly in confiderable efteem for deftroying worms in children, and are reckon'd good in colics and Ratulencies. In fome parts of Sweden and Lapland a bath with a decoction of this plant is made ufe of to affift in parturition,

\section{ARTEMISIA. Gen. pl. 945 .}

Recept. fubvillofum vel nudiufculum. Pappus nullus. Cal. imbricatus fquamis rotundatis, conniventibus. Cor. in ambitu feminx, obfoletx, longo ftylo donatæ.

\section{* Procumbentes ante florefcenitam.}

maritima I. ARTEMISIA foliis multipartitis tomentofis, racemis cernuis, flofculis feminfeis ternis. sp. $p l$. IIS6. (Ger. em. 1099. f. I. Moris. bif. S. 6. t. 2. f. 19 है 20)

Sea Worawood. Anglis.

Upon the fea-fhores, but not very common, as upon the coaft by Guilion-Loch. Dr. Parfons. 2 . IX.

The root and bafe of the ftalks are of a tough woody texture, and the whole plant cover'd with a white 
SYNGENESIA: POLYGAMIA SUPERFLUA. 467

a white cotton down: the flowers grow in compound nodding fpikes, each having three female florets in tine rim : the receptacle is naked.

The plant has a ftrong fcent of marum or camphor.

* Erecie herbacea, foliis compofitis.

abfinthium 2.

ARTEMISIA foliis compofitis multifidis, floribus fubglobofis pendulis; receptaculo villofo. $S p$. pl. II88. (Ger. em. 10g6. f. 1. Pet. berb. t. 20. f. I. Moris. bift. f. 6.t. I. f. I. ordinis inferioris. Gmelin. Sibir. II. p. 1 29. t.63. Blackwell. t. 16.)

Common Wormwood. Anglis.

In wafte places, and by way-fides, as about Aberlady, and the Queen's-Ferry, \&c. Dr. Parsons. 4. VIII.

The ftalk is two feet high, angular and branch'd: the leaves are of a hoary green on the upper fide, and cover'd with a white fatin down underneath, are foft to the touch, and pinnated: the primary pinne are divided into two lobes, the fecondary are bifid, trifid, quadrifid, and even pinnatind, the extreme fegments being obtufely lanceolate: the flowers are yellow, pendulous, and grow fix or feven in a fpike at the fummits of the branches, all leaning on the fame fide, and one only on a peduncle, which peduncle is longer than the calyx, but fhorter than the fubtending leaf: the fales of the colj $x$ are fmooth, five in number, the exterior ones longett and $\mathrm{Hh}_{2}$ narrowelt, 
narroweft, the interior ones oval: the receptacle has white downy hairs, and contains fifty florets or more, of which thofe in the rim are female.

It has a ftrong aromatic fmell and very bitter tafte, and is highly commended for its medicinal virtues. It ftrengthens the ftomach, removes obftructions of the liver and fpleen, creates an appetite and deftroys worms. Haller affirms, from his own experience, that from a long ufe of it he has kept off the gout. The forms in which it is ufed are either in a fpirit, in juice, an oil, an extract, or a falt. The fixed falt is purely alcaline, and well-known as a famous febrifuge and ftomachic.

In fome parts of England the plant is ufed inftead of hops to brew ale with.

The falt of it, or indeed any other aikali put into four beer, inftantly cures its acidity

Sheep by eating it have their flefh rendered bitter, and cows their milk, but horfes are faid to have been killed by it.

Eropoli affirms, that the fmell of it will drive away ants.

vulgaris 3. ARTEMISIA foliis pinnatifidis, planis, incifis, fubtus tomentofis; racemis fimplicibus recurvatis; floribus ovatis; radio quinquefloro. Sp. pl. 1188 . (Ger. em. 1103.f. I. Moris. bift. . 6.t. 1. f. 1. medii ordinis ad dextram. Blackwell t. 431) Mugwort. Anglis. 
SYNGENESIA : POLYGAMIA SUPERFLUA. 469

An liath-lus. Gaulis.

In wafte places and in cultivated grounds frequent. 24. VIII.

The ftalk is erect, three or four feet high, fometimes red and fometimes green: the leaves are green above, but white and hoary underneath, pinnatifid, the fegments lanceolate, oppofite, acutely dented, the extreme one Rightly divided into three lobes: the upper leaves are linear and undivided: the flowers are feffile numerous, erect, and grow in spikes compounded of many lefer Spicule arifing from the ald of the leaves: the fcales of the colyx are covered with a cotton down: the florets are red, and about 13 in a caly $x$ : the receptacle is flat and finooth.

An infufion of this plant in white wine, or a bath made of it, has always been efteemed an emmenagogue, and ufeful in dificult parturition.

The Gaponefe moxa formerly much ufed in cauteries for curing the gout, is no other than a fpongy inflammable fubftance prepar'd from the medulla of the ftalk of this plant.

The leaves when young and tender are frequently made ufe of by the highlanders as a pot-herb.

The country people in Sweden drink a decoction of them for the ague.

GNAPHALIUM. Gen. pĩ. 946 .

Recept. nudum. Pappus plumofus. Cal. imbricatis;

$$
\text { II h } 3
$$

fquamis 
$47^{\circ}$ SYNGENESIA : POLYGAMIA SUPERFLUA.

fquamis marginalibus rotundatis, fcariofis, coloratis.

\section{* Argyrocome calycibus albis.}

dioicum I. GNAPHALIUM farmentis procumbentibus, caule fimpliciffmo, corymbo fimplici, foribus divifis. Lin. Jyft. nat. p. 545. Horibus dioicis Sp.pl.p. II99. (Ger. em. 640. f. 4, 5, E 64I.f. 6. Pet. berb. t. 18.f. 4. Moris. bift. S. 7.t. 11. fig. Jecunda ordinis inferioris.)

Mountain Cudweed or Cat's-Foot. Anglis.

It is frequent in dry barren grounds both in the highlands and lowlands, as on the hills about Artbur's-Seat at Edinburgh, \&c. 24. VI.

The root throws off many trailing fhoots, but the flowering ftalks are ereet, three or four inches high, unbranched, and terminated with a clufter of white or red flowers: the radical leaves are fpoon-fhap'd, or oval and wideft at the extremity, and narrow and linear towards the bafe, green on the upper fide, but white and hoary underneath: the ftalk is woolly, and the leaves upon it feffile and lanceolate: the flowers are female on one plant, and hermaphrodite on another: the calyx of the female flowers is nearly cylindrical, of the hermaphrodite roundifh: the fcales are dry obtufe and generally white, but in the hermaphrodite flowers are often of a bright red.

alpinum 2. GNAPHALIUM farmentis procumbentibus, caule fimplicifimo, capirulo terminali aphyllo, foribus oblongis? 

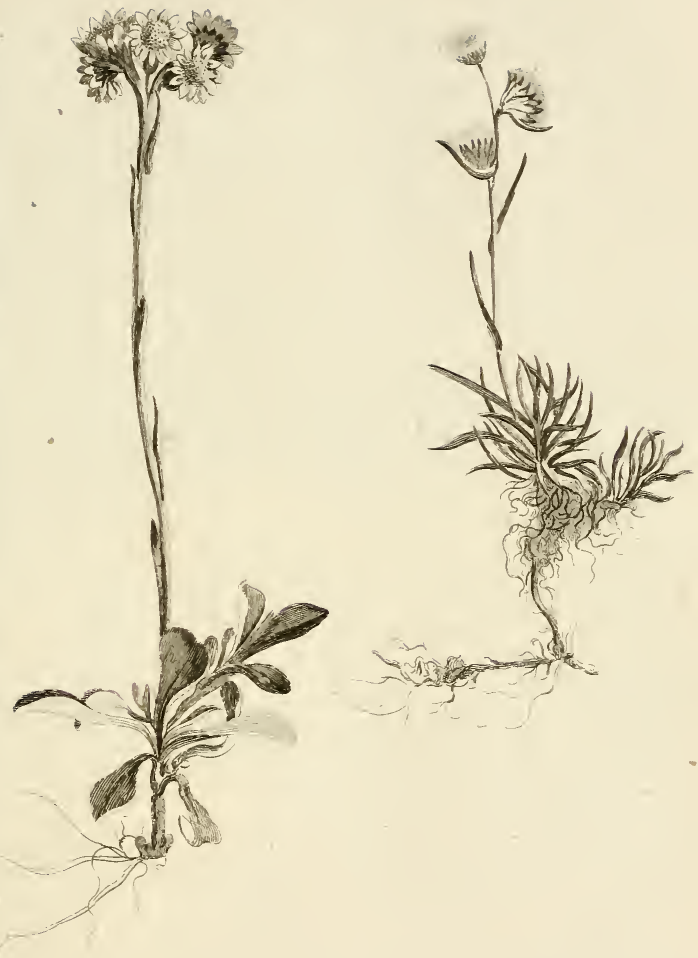

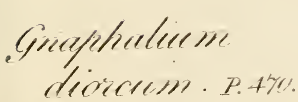

enerfiterlenen

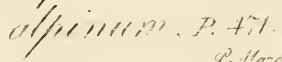
Moves Grifitits ad 


oblongis? Sp.pl. Irgg. Haller. hift. Airp. Helvet. n. 149. (Scopol. Flor. Carniol. n. 104S.t. 57. noftre plante fimillima, fed radix abfque Jarmentis. Oed. Dan. t. 332. non malè reprefentat, fed Folium in noftra planta flori fubjicitur. vid, fig. noft.)

Alpine Clidweed. Anglis.

Upon the tops of the highland mountains not unfrequent, as on Creg-cbaillech, near Finiarig, in Breadalbone, upon Mal-gbyrdy, and upon the mountains of Glenlyon, Glenurcby, and Glenco, \&c. Mr. Stuart. 24. VIII.

The root throws off feveral hoots, confifting of tufts of narrow linear leaves one third of an inch long, the flowering ftalk is erect, three inches high, covered with a white cotton fubftance, and furnifhed with three or four leaves fimilar to thofe of the fhoots, but rather longer : three or four flowers grow near the top of the ftalk in the manner of a fpike, one only from the ele of each leave, fometimes feffile, and fometimes fupported on a fhort peduncle: the calyx is nearly cylindrical, the fcales acutely oval, a little downy at the bafe, the apex and margins dry, pellucid and fufcous : the florets are moftly female, but a few in the centre of the difc are fufcous and hermaphrodite:

The caly'x in this fpecies is extremely like that in the following, but the habit of the plant is to. tally different.

$$
\text { * Filaginoida calycibus cinereis. }
$$

jylraticun

GNAPHALIUM canle lierbaceo fimplicifimo crecto, 
erecto, floribus fparfis. Lin. Jyft. nat.p. 545. Sp. pl. 1200. (Ger. em. 639.f. 1. Pet. berb. t. 18.f.

6. Moris. bift. f 7.t. 11. f. 1. Scopol. Fl. Carniol. n. 1046.t. 56. Oed. Dan. t. 254)

Spiked upright Cudweed. Anglis.

We obferv'd it upon dry paftures in the highlands frequently. It grows likewife in woods and thickets. of ? VIII.

Several ftalks generally arife from the fame root, but fometimes only one, erect, unbranched, ten or twelve inches high, covered with a white cotton down, befet the whole length with long, linear, acute leaves, greenifh and downy on the upper fide, but white and hoary underneath, growing alternately one above another, and fhorter by degrees towards the top of the ftalk.

The flowers grow in one common, long, thick fpike, compounded of numerous other spicula, arifing from the alce of the leaves, and bearing each from one to three, four, or more flowers: the calyx is nearly cylindrical, the fales ellipti. cal, green at the bafe, fufcous towards the apex, pellucid and fhining on the border : the florets are yellowifh, extremely fine and flender, molt of them female, but a few hermaphrodite ones in the centre of the difc.

There is a variety of this plant which fometimes occurs upon the highland mountains, having wider leaves, and a fhort cluftered fpike of black flowers. 
uliginofum 4 GNAPHALIUM caule herbaceo ramofo diffufo, floribus confertis terminalibus. Lin. Jyft. nat. p. 545. sp. pl. 1200. (Pet. kerb. t. 18.f. 7. Ger. em. 639.f. 2. Moris. bift. f. 7. t. I . f. 14. ordinis fuperioris ad dexir am.)

Black-headed Cudweed. Anglis.

In damp foils, and where water has frood in the winter, frequent. $\odot$. VIII. IX.

The ftalk is widely branched, the branches procumbent, white, and hoary: the leaves are linear, wideft towards the extremity, and covered with a cotton down, efpecially on the under fide: the flowers are very fnall, fefile, and grow in clufters at the fummits of the branches, imbedded in down amongit the leaves: the fcales of the calyx are of a dark thining fufcous color, in the younger ones yellowin: the central florets are hermaphrodite, and ftreak'd with yellow lines; the female ones are extremely fine and nender.

\section{CONYZA. Gen. pl. $95^{\circ}$.}

Recept. nudum. Pappus fimplex. Calyx imbricatus, fubrotundus. Cor. radii trifidi.

Jquarrofa $\mathrm{I}$.

CONYZA foliis lanceolatis acutis, caule herbaceo corymbofo, calycibus fquarrofis, Lin. Jyt. nat. $p$. 547. Sp.pl. 1205. (Ger. em. 792. Pet. berb.t. I8. f. I. Moris. bift.f. 7. t. 19.f. 23.)

Plowman's Spikenard. Ainglis. 
474 SYNGENESIA: POLYGAMIA SUPERFLUA.

In dry mountainous foils, but rare. We have Dr. Perfon's authority for inferting this plant as a native, who believes that he gathered it near Blair, in Athol. ơ. VIII.

The falk is two or three feet high, erect, firm and branch'd: the leaves are foft and hairy, a little hoary underneath, of an oval-lanceolate form, fightly ferrated on the edges: the flowers are yellow, and grow in loofe umbels at the tops of the branches: the calyx is nearly cylindrical : the fcales are oval-lanceolate, the inferior ones largeft and almoft all green, the others yellowin, with green patent apices: the difc has many fine flender female florets in the rim, and yellow hermaphrodite ones in the centre.

The plant has an aromatic fmell.

** Rodiati.

\section{ERIGERON. Gen. pl. 95 I.}

Recepi. nudum. Pappus pilofus. Cor. radii lineares, anguftifima.

QOTE I.

ERIGERON pedunculis alternis unifloris. $s p \cdot p l$.

1211. (Ger. emac. 484. f. 10. Pet. berb. t. 16. f. 4. Moris. hift. S. 7. t. 20. f. 25. Sed vitiofc̀ quoniam caulis $\&$ folic glabra funt expreffa. Column. ecph. 2.p. 25.t. 26)

Blue Gleabane. Anglis.

In dry mountainous paftures frequent. 24. VIII.

The root is fibrous and acrid: the ftalk a foot high, rough and hairy, branched near the top with al. 
SYNGENESIA: POLYGAMIA SUPERFLUA. 475

ternate peduncles, bearing each a fingle flower: the leaves are a little hairy, often undulated on the edges, of a narrow lanceolate form, and grow alternate on the ftalk: the fcales of the calyx are linear and downy: the difc of the flower is yellow; but the florets which compofe the rays are bluifh or flefh-color'd, very narrow or filiform, erect, bind, and about forty in number.

\section{TUSSILAGO. Gen. p?. 952.}

Recept. nudun. Pappus fimplex. Cal. fquama æquales, difcum æquantes, fubmembranaceæ.

farfara 1. TUSSILLAGO fcapo unifloro imbricato, follis fubcordatis angulatis denticulatis. Sp. pl. 1214. (Ger. cm. 811.f. 1. Pet. berb.t. 17.f. 7. 8. Moris. bift. S. 7.t. 12.f. 1. crdinis Juperioris. Blackwell t. 204)

Common Colt's-Foot. Anjlis.

An gallan gainbhich, Chluas.liath. Gaulis.

In moif and clayey foils frequent, as on the banks of the water of Leith, Ec. 24. III. IV.

The floral ftalk comes up before the leaves, is about fix inches high, befet with many fcales, and bears a fingle yellow radiated flower at the top: the leaves are white and hoary underneath : the calyx confifts of one feries of narrow lanceolate fcales, all equal: the female forets which compofe the rays are numerous, very narrow, and intire: the Aowers nod before the burfting 
476 SYNGENESIA: POLYGAMIA SUPERFLUA.

of the antbera, but are afterwards erect: from the time of flowering to the ripening of the feeds is about 18 days.

The leaves fmoak'd in the manner of tobacco, or a fyrup or decoction of them and the flowers, ftand recommended in coughs and other diforders of the breaft and lungs. Practice, however, feems almolt to have rejected it.

A kind of tinder or touchwood is in fome countries made of the roots, or the downy fubftance which adheres to them.

bybrida 2. TUSSILAGO thyrfo oblongo, flofculis femineis nudis plurimis. Sp.pl. 1214. (Dillen. Hort. Eltham. 309. t. 230. f. 297.)

Long-Italk'd Butter-bur. Anglis.

By river fides, but not very common. We obferv'd plenty of it on the banks of the river $E / k$, on the borders of Annandale, near Netberby. 24. IV.V. The floral ftalk is a cubit high, unbranched, fcaly, and purplifh: the flowers are numerous, fmall, pale purple, or whitih, without rays, and grow in a long conic fpike: the peduncles are two inches long, branch'd, and bear each feveral Rowers which are often pendulous by reafon of the llength of the peduncles: the caly $x$ confifts of one feries of oval-lanceolate fcales: the florets are all female except one or two which are hermaphrodite: the down is longer than the calyx even in the young fowers: the leaves come up 
SYNGENESIA : POLYGAMIA SUPERALUA. 478 after the floral ftalks in the month of May, of a rounded cordate form, very large, often two feet vide, dented on the margin, woolly underneath, and fupported on footitalks.

petafites 3. TUSSILAGO thyrfo ovato, flofculis femineis nudis paucis. Syft. nat. p. 550. Sp.pl. 1215. (Ger. em. 8 I 4. fig. I, 2. Moris. hift. S. 7. t. 12. f. I. ordinis fuperioris ad dextram. Pet. berb. t. I $5 . f . \mathrm{I}$, 12. H. Aichftatt bybern. tab. 5.f. r. Blackwell t. 222.)

Common Butter-bur. Anglis.

An gallan mòr. Gaulis.

In wet meadows and by river fides frequent, as by the new well at Leith, \&c. 24 . IV. V.

The floral ftalk is 10 or 12 inches high, terminated with a thick oval fpike of purplifh flowers, much larger than thofe of the preceding fpecies, but much fewer in number: the peduncles are fhort and fimple, and generally bear only a fingle flower : the calyx is bell-fhap'd or inverfely conical, and confifts of four feries of reddifh lanccolate fcales : the florets are almoft all of them hermaphrodite, but fometimes a few female ones are found in the rim In other refpects it agrees with the preceding.

The leaves of thefe are the largeft of any native plant in Great-Britain, and in heavy rains are frequently obferv'd to afford a feafonable fhelter to poultry and other fmall animals. 
4'78 SYNGENESIA : POLYGAMIA SUPERFLUA.

The root dug up in the furing is refinous, and aromatic. A drachm of it in a dofe has been fometimes given as a fudorificalexipharmic, but as it poffeffes thofe virtues but in a fimall degree, it has loft its reputation in the fhops.

\section{SENECIO. Gen. pl. 953 .}

Recept. nudum. Pappus fimplex. Cal. cylindricus, calyculatus; fquamis apice fphacelatis.

* Floribus flosculojis.

rulgaris I. SENECIO corollis nudis, foliis pinnato-finuatis amplexicaulibus, floribus fparfis. Sp. pl. 1216. (Ger. em. 278. f. 1. Blackwell t. 132. Oed. Dan. $513.0 p t$.)

Common Groundfel. Anglis. Am bualan. Gaulis.

In gardens and wafte grounds common. $\odot$. IV.IX. The ftalk is erect, angular, branch'd, a foot high, thick, and fucculent : the leaves are numerous, green, nightly cover'd with a cobweb down, fet file and wide at the bare, pinnatifid, the fegments and infteritices ferrated: the flowers grow in cluters at the fummits of the branches, yellow, and without rays : the calyx confints of one one feries of linear acute fcales with black apices: at the bafe of the calyx are leveral thore fupplementary fcales, which have alio black fummits: the feeds are of a long elliptic form, and furrow'd.

The 
The plant lives about three months. From the burfting of the antberce to the perfecting the feeds takes up 18 days: all the flowers which terminate the principal ftalk ripen their feeds in feven weeks; after which thofe of the branches proceed to the fame operation : the calyces nod after the anthers are burft till the feeds are ripe.

A ftrong infulfion of this plant acts as an emetic. The highlanders ufe it externally in cataplafms as a cooler, and to bring on fuppurations. Finches and other fmall birds are fond of the feeds.

\section{* Fioribus radiatis, radio revoluto.}

vifcofus 2. SENECIO corollis revolutis, foliis pinnatifidis vifcidis, fquamis calycinis laxis longitudine perian. thii. Sp. pl. 1217. (Dillen. Eltbam. 347. t. 258. $f \cdot 33^{6)}$

Vifcid Groundfel. Anglis.

In wafte places near towns and villages, as a: Leven, on the coaft of Fife, near the falt-works, and at Dyfart by the peer, and at Charles-Towon, the great lime-works of Lord Elgin, in plenty. $\odot$. VIII.

The ftalk is two or three feet high, widely branched, and together with the whole plant covered with vifcid hairs : the flowers are yellow, much larger than thofe of the preceding, and grow in loofe umbels, two or three on a peduncle. The calyces are vifcid, the fupplementary fcales at the bafe lax and hairy, and fometines almoft as long as 
480 SYNGENESIA : POLYGAMIA SUPERFLUA.

the primary calyx: the flower is radicated, the rays revolute and tridenten at the fummits.

fylvaticus 3 S. corollis revolutis, foliis pinnatifidis denticulatis, caule corymbofo erecto. Sp. pl. 1217. (Dillen. Eltbam. 258. t. 258. f. 337. Ger. em. 278.t. 2 . non malè reprefentat.)

Small-flower'd Groundfel. Scented Cotton Groundfel. Anglis.

In dry upland foils, upon banks and mounds of earth, \&c. ๑. VII.

The ftalk is three or four feet, erect and branched: the leaves are foft, downy and ftrongly fcented; they are pinnatifid, and their fegments alternately great and fmall : the flowers are numerous, fmaller even than thofe of the firft fpecies, and grow in umbels: the calyx is fmooth, and fhap'd like a truncated cone, having a fmall nightly-hairy ligament or bractea near the bafe: the flowers are vellow and radiated; the rays very fhort and revolute.

*** Florilus radiatis, radio patente, foliis pinnatifidis.

jacobsa 4. SENECIO corollis radiantibus, foliis pinnato-lyratis; laciniis lacinulatis, caule erecto. $s p . p l$. 121 c. (Ger. emac. 280. f. I. Pet. kerb. t. 17.f. x. Moris, biff. .. $7 . t .18 . f .1$ )

Common Ragwort. Anglis.

In paftures and by way-fides frequent, 4 . VII. VIII. 
SYNGENESIA : POLYGAMIA SUPERFLUA. 481

The ftalk is two or three feet high, ftriated, erect, and branched: the leaves are generally green, without any down or hoarinefs; the radical ones are pinnatifid at the bafe only, with a large, oval, fintlated fegment at the extremity : thofe on the ftalk are pinnatifid throughout, their fegments laciniated : the flowers grow in umbels, and are yellow and radiated : the peduncles are generally downy, the calyx fmooth, the fcales blackin at the tips; the rays patent, and about 12 in number: the hermaphrodite florets in the difc about 60.

$\beta$.

The flowers are fometimes, but very rarely, feen without rays.

aquaticus $\gamma$ Another fingular variety of this plant, which many authors confider as a diftinct fpecies, often occurs in wet places, and by the fides of lakes. The radical leaves of this ftand on long footftalks, are oval, and dented on the edges. Thofe in the lower part of the ftalk are pinnatifid at the bafe, and terminated with a large oval dented lobe: but the uppermoft of all are generally pinnatifid to the end. The flowers are the fame as in the common fort. Vid. fig. (Ger. em. 280. $f .3$, Pet. berb.t. 17, f. 2. Loefel Flor. PruJf. p. 129 , i. e. 35 , bona.)

Water Ragwort. Anglis. 4. VII. VIII.

The leaves of thefe plants have a bitter and fomewhat acrid tafte: a decoction of them will dye grcen, but the colour does not ftand well. 
482 SYNGENESIA : POLYGAMIA SUPERFLUA.

\section{ASTER. Gen. pl. 954.}

Recept. nudum, Pappus fimplex, feftilis. Corol. radii plures 10. Cal. imbricati; fquamæ inferiores patula.

Tripolitum I ASTER foliis lanceolatis integerrimis carnofis glabris, ramis inæquatis, floribus corymbofis. $S p$. pl. 1226. (Ger. esnac. 413, f. 1, 2, Pet. berb. t. 17, f. 10, 11. Gmel. Fl. Sibir. 186. t. 80, f. 10. Moris. bift. $\int . t .22 . f \cdot 36,37$.)

Sea Starwort. Anglis.

In falt marfhes on the fea coalts not unfrequent. 2 . VIII. IX.

The ftalk is fmooth, ftriated, branched towards the top, and varies in height from nine inches to four or five feet; whence fome authors have made a greater and a leffer variety : the leaves grow alternate upon the ftalk; their figure, \&c. is expreffed in the fpecific difference : the flowers grow in thin loofe umbels at the fummits of the branches: the calyx is fhort and cylindrical: the fcales obtufe, and commonly tinged with red on the edges: the flowers are $3-4$ ths of an inch in diameter: the dif yellow, the rays blue; but B. a variety of it fometimes occurs without rays. Vid. Pet. berb. t. 17, fig. i2.

\section{SOLIDAGO. Gen. pl. 955 .}

Recept. nudum. Pappus fimplex feffilis. Cor. radin circiter 5. Cal. fquamie imbricatæ, claufe. viristrian SOLIDAGO caule fubflexuofo angulato, racemis. paniculatis 
SYNGENESIA : POLYGAMIA SUPERFLUA. 483 paniculatis erectis confertis. Sp. pl. 1235 (Ger. emr. 430. f. 1, 2. Pet. berb.t.16, f. 9, 10. Moris. bift. f. $7 . t .23, f .4$, ordinis Juperioris, \& fig. 20. ordinis medii.)

Golden Rod. Anglis.

In rough mountainous paftures, and in woods trequent. 24. VIII.

The root is woody: the ftalk firm, a little rough, and varies from fix inches to five feet high; its common height about a yard: the leaves are a little hard, and rough to the touch; the lower ones oval-lanceolate, generally a little ferrated, and fupported on footftalks: thofe on the ftalks are elliptical, fometimes nightly ferrated, but commonly entire.

The flowers are yellow, and grow in a fpiked panicle: the fcales of the calyx are lanceolate, of unequal length, and of a pale green colour: the female florets which compofe the rays are in number from five to eight; the hermaphrodite ones in the difc from ten to twelve. The feed is alittle hairy, pointed at the bafe, convex on one fide, and plain on the other.

B. A variety of this plant frequently occurs, growing out of the rocks near the fummits of the highland mountains, which is often not above fix inches or a foot high, and bears fewer flowers, growing in a fhorter and more compact fpike: the leaves are alfo frequently a little downy, and the plant flowers earlier. This is the S. Cam- 
$4^{84}$ SYNGENESIA : POLYGAMIA SUPERALUA.

brica of Hudf. Flor. Angl. vid. Pet. berb. t. 16. f. II.

The leaves have an aftringent and bitter tafte, and are efteemed as a good vulnerary and diuretic: they are recommended in the ftone and gravel, and in ulcers of the kidnies and bladder, three drachms of the powder being taken every eighth hour.

\section{INULA, Gen. pl. 956.}

Recept. nudum. Pappus fimplex. Antbere bafi in fetas duas definentes.

belenium * I INULA foliis amplexicaulibus ovatis rugofis, fubtus tomentofis, calycum fquamis ovatis. Sp.pl. 1236. (Ger. em. p. 793. Pet. berb. t. 16. f. 1. Moris. bift. f. 7. t. 24. fig. ultim. ad bafin. Black. well t. 473. )

Elecampane. Anglis.

Obferved in the low-lands near houfes and gardens, by the Rev. Dr. Burge/s, of Kirkmichael, who does not believe it to be properly a native. 24 . VIII.

It is one of the largeft of herbaceous plants, being of ten fix feet high : the root is thick and brown: the leaves (befides what is imply'd in the lpecific difference) grow alternate, are ferrated, and the lower ones ftand on footftalks : the ftalk is erect and ftrong, and branched towards the top : the flowers terminate the branches, and are large and yellow: the fcales of the calyx are oval, wide, reflex'd, imbricated, and refemble leaves: 
SYNGENESIA : POLYGAMIA SUPERFLUA. $4^{8} 5$ the rays of the flower are numerous, narrou, and terminated with three acute dents: the down of the feeds is reddifh, each hair of it finely dented on one fide.

The root is acrid, bitter, and aromatic: a conferve of it ftands recommended in afthnias, and other diforders of the breaft and lungs, as good to promote expectoration. The decoction of it in water, or an infufion in wine, or a fpirituous extract, are alfo extcll'd as a ftomachic and fudorific, and are therefore prefcrib'd in crudiries of the ftomach, bad digettions, the hypochondria, and contagious difeafes. Outwardly applied, a decoction of it is faid to cure the itch. Bruifed and macerated in urine, with balls of athes and whortle berries, it dyes a blue colour.

\section{DORONICUM. Gen. pl. 959 .}

Recept. nudum. Pappus fimplex. Calycis fquama duplicis ordinis æquales, difco longiores. Senn. radii nuda pappoque deftituta.

iardslian- DORONICUM foliis cordatis obtufis denticulatis, ches * 1 . radicalibus petiolatis, caulinis amplexicaulibus. Sp. pl. 1247. (Ger. em. ;62.f. 7. Moris bif. f. 7. t. 24. f. 4. Miller ic. 128. Blackruell t. 239.) Great Leopard's Bane, or Wolf's-Bane. Anglis. We obferved it in feveral places in the lowlands. as about Hoddain caftle, in Annanáale, \&c. but always near houfes, fo that we fufpect it not to be indigenous, but as it feems to be naturalized 
we thought it deferved a place in this collection. 4. V. VI.

The root is thick, jointed, creeping, and barbed with many fibres: the ftalk is two or three feet high, hairy, furrow'd, and divided towards the top into three or four branches, each terminated with one large yellow radiated flower: the leaves are rather foft and harry, the radical ones obtufely heart-haped, and fupported on foot1talks; thofe on the ftalk but few in number, embracing it at their bafe, and of a long oval form: the fcales of the calyx are about 26 in number, compofed of a double feries, are narrow, lanceolate, and as long as the rays of the flower: the female Borets which compofe the rays are ftreak'd with green lines, and about 22 in number: the hermaphrodite ones of the difc are about 178 : the feeds of the rays are nearly triangular, ftreaked' with ten lines, and are deftitute of down : thofe of the difc are roundin, hairy, and crowned with a down, which is lightly plumofe: the receptacle is convex and hairy. From the burfting of the Antbere to the ripening of the feeds takes up the fpace of one month.

Many writers have fuppofed the root to be poifonous, and that it would deftroy wolves, dogs, and other animals. Others have reckoned it an antidote to poifon: but the prefent practice re. jeessit. 


\section{BELLIS Ger. 1 l]. 962 .}

Recept. nudum conicum: Pappus nullus. Call hemifphrincus ; fquamis æaualibus. Sem. obovata. perennis I. BELLIS fcapo nudo. $\$ p$. pl. 1248. (Ger. em. 636 . f. 4. 5. Pet. berb. t. 19. f. 2. Moris bift. f. 6. $t$. 8. f. 26 EJ 29. Blackwell t. 20 . Oed. Dan. t. 5०3.opt.)

Common Daifie. Anglis,

Gowan. Scotis, Noinein. Gaulis.

In paftures frequent. 27. IV. IX.

The leaves are obtufely oval, thick and crenazed, nightly hairy, and expanded round the root in a circle: the floral falks are naked, a little hairy, from four to eight inches high, bearing each one flower: the caljex is compofed of two feries of erect, equal, lanceolate fcales, expanded horizontally at top, and about thirteen in number: the rays of the flower are white, commonly tinged with red on the outfide, and fometimes all red, difpored in two ranks, and about fifty in number: the difc is yellow, and confifts of about II 7 florets: the rays clofe together in rainy weather, and in the night.

The tafte of the leaves is fomewhat acid, and, in fcarcity of garden-ftuff, they have in fome countries been fubstituted as a pot-herb. It is at prefent not ufed in medicine. 


\section{CHRYSANTHEMUM. Gen. pl. 966.}

Kecept. nudum. Pappus marginatus. Cal. hemifphæricus, imbricatus; fquamis marginalibus membranaceis.

\section{* Leucantbema.}

leucantbemun I.

CHRYSANTHEMUM foliis amplexicaulibus oblo:ıgis, fupernè ferratis infernè dentatis. Sp. pl. 1251. (Ger. em. 634.f. I. Pet. berb. t. 19.f. r. Moris. bift. f. 6.t. 8. fig. I. notata, fed secunda ordinis fuperioris. Blackwell t. 42.)

The great Daifie, or Ox-eye. Anglis.

Am breínein-brothach. Gauiis.

In dry paftures frequent, both in the highlands and lowlands. 24. VI. VII.

The ftalk is a foot or more high, ereet, and generally divided into a few branches towards the top, but is fometimes fingle: the radical leaves are obtufely oval, crenated, and fupported on footftalks : thofe on the ftalk are feflile, nearly lanceolate, and ferrated, efpecially towards the upper part, but at their bafe are deeply and acutely dented or pinnatifid, and embrace the Italk: a fingle large flower terminates each branch, having a yellow dife, and white rays: the ftyles in the female florets are faffron color'd: the feeds are furrow' $d$, and have ten angles.

CHRYSAN'THEMUM foliis pinnatis multifidis, caule ramofo diffufo. Sp. pl. 1253. (Moris. bift. [.6.t. [2. . . 8.3 
SYNGENESIA: POLYGAMLA GUPERELUA. 489

Canomile Daifie. Listis.

By fields and way-fides, but not common. Sibbaid. $\odot$. Vill.

The ftalk is near a foot high, often reclining at the bafe, and widely branched: the leaves are pinnated, and finely divided, like cbamomiie: a large Alower, with white rays and a yellow dife, terminates each branch: the calyx is flattifh : the fcales are unequal, membrane on their margins: the rays are patent, but not deflex'd: the receptacle hemifphrical and naxed The plant has no ill favour.

\section{** Cbryfantbema.}

Segetum 3. CHRYSANTHEMUM foliis amplexicaulibus, fupernè laciniatis, infernè dentato-lerratis. $s p$. pl. 1254. (Ger. em. 743 f. I. Pet.herb. t. 19. f.6. Moris. bif. f. 6.t. 4. f. 1. ordinis medii.)

Corn Marigold. Anglis.

Gules, Gools, Guills, or Yellow Gowans. Scotis. An dithean. Gaulis.

In corn-fields frequent. $\odot$. VIII.

The ftalk is a foot or eighteen inches high, ereet and branched: the leaves grow alternate, are fmooth, and of a blue green or glatcous colour: each branch is terminated with a large radiated flower, having the rays and dife both yellow.

Thefe golden flowers turn towards the fun all day, an ornament to the corn-fieids, and afiord a pleafing fight to the paffenger, but are fo very 
detrimental to the hufbandnan, that a law is in force in Denmark, which obliges the inhabitants every where to eradicate them out of their grounds.

This noxious weed is faid to be deftroyed by dunging the foil where it grows in the Autumn, by. letting it lie fallow one fummer, and by harrowing the ground in about five days after fowing the feeds for the future crop. Lin. Fl. Suec. 762 .

\section{MATRICARIA. Ger. \%. 957.}

Recept. nudum. Pappus nullus. Cal. hemifpharicus, imbricatus; fquamis marginalibus folidis acutiufculis.

MATRICARIA foliis compolitis planis, foliolis ovatis incifis, pedunculis ramofis. Sp. pl. 1255. (Ger. emac. 652.f. 1. Pet.lierb. t. 19.f.5. Blacksell $t, 192$.

lieverfew. Anglis.

In wafte places near houfes and gardens, and fometimes in corn-fields. Mr. Stuart. ô. s. 24. VII. VIII.

'The falk is credt; a yard high, and branched: the leaves are nightly downy, fof and tender, of a thie green colour, compored of fix pair of pinno, with an odd trifid one at the extremity, Thefe finne are nearly oval and pinnatifid, their fegments again obtufely ferrated.

the flowers grow in an umbel upon branched peJuncies, and have yellow difes with white rays: the frales of the caly have dry membranaceotis nargins. 
SYNGENESIA : POLIGANIA SUPERFLUA. $49^{\mathrm{t}}$ margins, and therefore the plant more properly belongs to the preceding genus.

The whole plant has a ftrong fragant finell, and has always been efteem'd a good einmenagogue, and very ferviceable in hyfteric complaints. The beft way of taking it is in a night infufion in the manner of tea. It is alfo an agreeable carminative and bitter, ftrengthens the ftomach, and difperfes flatulencies. The exprefs'd juice is faid to kill worms in the bowels. It has likew:fe been recommended as a febrifuge, whence it took it's Erglifs name.

maritima 2 MATRICARIA receptaculis hemifphrricis, folis bipinnatis fubcarnofis, fupra convexis, fubtus carinatis. Sp.pl. 1256. (Raj. Synop. 186.t. . . $f$. 1.)

Sea Feverfew. Anglis.

On the fea-coafts in fandy foils, as in the inand of Bute, and on the weitern fide of Cantire, between Macbrianish and Barr, \&cc. 24. VII.

The ftalk is nine inches high, fmooth, red, firn, and diffuely branched: the leaves are of a dark green colour, fmooth and fucculent: the flowers have a yellow dife, and white patent rays: the plant has fomething of a fweet but very little frent.

ibamomilla MATRICARIA receptaculis conicis, radiis paten3. tibus, fquamis calycinis margine aqualibus. Syjf. nat. 563. Sp. pl. 1256. (Ger. em. 754.f. I. Mcris. hiff. f. G.t. 12. f. 7 . Blackseilst. 298.) 
Fine-leav'd Feverfew, or wild upright Camomile, with little fcent. Anglis.

In corn-fields and wafte places frequent. $\odot$. VII. VIII.

The ftalk is a foot ard a half high, erect, and branched: the leaves are doubly pinnate, the pinnula divided into plain capillary fegments: the calyces are almolt flat, or nightly hemifphærical: the fcales green, with a fufcous margin: the difc of the flower is yellow and conical; the rays white, about 20 or 22 in number, and nearly of the fame length with the diameter of the calyx: the receptacle is oblong, and almoft cylindrical. The plant has a bitter tafte, a fweet, but very little fmell, and has nearly the fame virtues with the ANTHEMIS nobilis Lin. or Roman Camomile.

The flowers are reckoned antifeptic, and approach in quality to the Peruvian bark. Twenty or thirty grains of them readily promote fweat, and are recommended as a cure for the ague; and, mixed with falt of wormwood, as excellent in fevers. A decoction of them is efteemed good in nephritic complaints, and to affuage the pains of the cholic and dyfentery. Baths, clytters, and cataplafms of them are alfo ufed in the laft intentions. A blue effential oil is obtained by diftillation from the flowers, which is fuppofed io contain all their virtues. 
SYNGENESIA : POLYGAMIA SUPERFI,UA. 493 fuaveolens? MATRICARIA receptaculis conicis, radiis de4.

flexis, fquamis calycinis margine aqualibus. Syjt. nat. $5^{6} 3$. Sp. pl. $125^{6}$. (Fig. nulla.)

Sweet-fcented Feverfew. Anglis.

We obferved it at the entrance of Glen-beg, near Glen-Elg, upon the weftern coaft of Iirvernesssire. ○. VIII.

We perceived no difference between this and the preceding, except that the rays were larger and deflex'd, and we fufpect it to be only a variety of it.

\section{ANTHEMIS. Gen. pl. 970.}

Recept. paleaceum. Pappus nullus. Cal. hemifphæricus, fubæqualis. Flofcuii radii plures quam 5 . nobilis * 1. ANTHEMIS tol is pinnato-compofitis linearibus acutis fubvillofis. Sp. pll. 1260 . (Ger. em. 755. f. 4. E flore pleno fig. 3. Pet. berb. t. 19. f. 10.) Sweet Camomile, Roman Camomile. Anglis. Obferved, by the Rev. Dr. Burgess, of Kirkmichael, amongt rubbih near gardens; but he does not believe it to be indigenous. 24. VIII.

The ftalks are near a foot long, procumbent, and branched: the leaves have a grateful aromatic fmell, and bitter tafte; they are Rightly downy, and doubly pinnate; the pinnula lanceolate, plain, and divided furcher into bifid and trifid fegments : the branches are terminated euch with one radiated flower, ftanding on a downy peduncle : the calyx is of a whitih green colour, the edges of the fcales filvery white: the dife of the 
494 SYNGENESIA : POLYGAMIA SUPERFLUA.

flower is yellow; the rays white: the receptacle chaffy, which is the principal diftinction of this genus.

This has much the fame virtues with the MATRICARIA cbamomilla before mentioned, but is generally preferred before it, chieflv we believe on account of its fragrant fmell. Its principal virtue is fuppofed to exift in the calyx, which is obtained by an effential oil.

$\operatorname{arv}(n)$ is 2. ANTHEMIS receptaculis conicis, paleis lanceolatis, feminibus coronato-marginatis. $s p . p l .1 z 6 \mathrm{l}$. (Pet. berb. t. 19.f.' S.)

Corn Camomile. Anglis.

In corn-fields, and by way-fides in gravelly foils, as in the lanes about Lafwade, between Dalkeith and Rojin, and on the north fide of Linlitbgow. Dr. Parjons. ơ. Vili.

The ftalk is near a foot high, firm, ftriated, and diffufely branched: the leaves are a little hairy, and have generally a white or hoary appearance, and are without fcent : they are doubly pinnate, the pinnule lanceolate, and terminated with a little beard or finule: the flowers grow fingly at the end's of the branches on long downy pe'duncles : the interior fcales of the calyx are wide, and membranaceous at the apex : the difc of the flower is yellow, the rays white, the receptacle conicall, and befet with Janceolate chaffy fcales, intermixed with the hermaphrodite florets: the feeds are quadrangular, and crowned at the top with a hort white membranaceous rim. 
cotula. 3. ANTHEMIS receptaculis conicis paleis fetaceis, feminibus nudis. Sp.pl. 1261. (Ger. em. 757.f. 1. Pet. berb. t 19. f. 12. Moris. bijt. S. 6. t. 12. f. 10. Blackwell t. 63)

Stinking Camomile, or Mayr-weed. Anglis.

In wafte places, corn fields, and by way-fides. $\odot$. VI. VII.

The ftalk is a cubit high, erect, branched, and furrow'd with about eight ftreaks : the leaves are fmooth, or nearly 10, doubly pinnatid : the pinnule narrow and lanceolate, the extreme one trifid: the fcales of the calyx are narrow, and very nightly membranaceous on the edges: the difc of the flower is yellow and conical: the rays white : the chaff on the receptacle fetaceous or brifte-Phap'd: the feed has no marginal crown, but only a pore at the top.

$\beta$. It varies fometimes with a double flower, as obferved by Sibbald, in bis Natural Hiftory of FifeSire.

The whole plant has a ftrong forid fmell, and, where it abounds, is often found to blifter the hands of weeders and reapers.

\section{ACHILLEA. Gen.pl. 971.}

Recept. paleaceum. Pappus nullus. Cal. ovatus, imbricatus. Floculi radii circiter 5 .

ptarmica x. ACHILLEA foliis lanceolatis acuminatis argutè ferratis. Sp.pl. 1266. (Ger. em. 606. f. 1. Pet. berb. t. 19.f. 3. Moris. bift. f.6.t. 12. fig. prinza inferioris ordinis. Bleckwell $\leqslant .276$. .)

Sneeze- 
Sneeze-wort, or Goofe-tongue. Anglis.

An cruai'-lus. Gaulis.

In moift meadows and paftures frequent, 4. VII. VIII.

The ftalk is a cubit high, or more, erect, firm, and branched : the Jeaves grow feffile and alternate, of a long lanceolate form, very finely and Inarply ferrated on the edges, fmooth, and of a firm but brittle texture: the flowers grow in loofe umbels: the difr is white; the rays white, and in number from feven to eleven: the calyw is downy, and the chaff on the receptacle downy.

The variety with a double flower is received into the flower-garden for ornament.

The plant has an acrid biting tafte, and has fometimes been ufed as an errhine to promote fneezing, and to cure the tooth-ach, by "drawing away the rheum from the jaws; but at prefent it is out of practice.

Cattle will readily eat it.

silitgfolium

2.

ACHILLEA foliis bipinnatis nudis; laciniis linear.bus dentatis; caulibus fupernè fulcatis. Syft. nat. 567. ip pl. 1267. :Ger. em. 1072. f. 2. Pet. kerb. t. 19.f. 4. Muris. bift. 1. 6. t. 11.f. 6 Eं 14. Blackwell t. 18.)

Yarrow, Milfoil or Nople Anglis.

A' chaithir-thalmhain, $\hat{A n}$ earr'-thalmhain, Lus chofgadh-na tola. Gaulis.

In paftures and by way-fides frequent. 24. VI. VIII. 
The ftalk is erect, a foot high, branched, and umbelliferous at the top: the leaves are either quice fmooth, or flightly hairy, very long, and finely divided; compounded firft of 20 or 25 pair of fhort pinne, each of which is fubdivided into three or even reven pair of pinnule, which are again cur into trifid or quinquefid lanceolate fegments, all of them dotted and retculated: the fcales of the calyx are green, with pale brown margins : the flowers are fmall and numerous: the difc is either of a pale yellow colour or red: the rays are only four or five, very fhort and plain, not above half the length. of the calyx, and either white or red: the feed is oblong, comprefs'd, and has a white margin.

The plant has an aftringent quality, and is reckon'd good to ftop all kinds of hømorrhagies, and to heal wounds, but is out of ufe in the prefent practice. The highlanders ftill continue to make an ointment of is to heal and dry up wounds. The common people, in order to cure the headach, do fometimes thruft a leaf of it up their noftrils, to make their nofe bleed; an old practice, which gave rife to one of its Englifh names. Linneus informs us, that the inhabitants of Dalekarlia, in Sweden, mix it with their ale inRead of hops, and that it gives the liquor an intoxicating quality.

Cattle do not refufe to eat it.

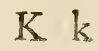




\section{POLYGAMIA FRUSTRANEA.}

\section{CENTAUREA. Gen. pl. 984.}

Recept. fetofum. Pappus fimplex. Cor. radii. infundibuliformes, longiores, irregulares.

Cyani. caiycinis fquamis Jerrato-ciliatis.

migrax. CENTAUREA calycibus ciliatis; fquamula ovata, ciliis capillaribus erectis, foliis lyrato-angulatis, floribus fofculofis. Sp. pl. 1288. (Ger: em. 727.f. 1. Pet. berb. t. 22.f. 8 E 9. Parkinfon. berb. 468.)

Common Black Knapweed. Anglis. The Horfe-Knot. Scotis auftralibus.

In meadows and peftures not unfrequent, both in the highlands and lowlands. $\delta$. VIII.

The ftalk is two or three feet high, firm, branch'd and angular: the leaves are rough and hard, the lower ones pinnatid half way down to the rib, or elfe fparingly indented; the upper ones oval-lanceolate and entire. Sometimes it varies, with all the leaves entire: the flowers are purple: the florets all tubular and hermaphrodite, no neuter ones in the rim: the calyx is black, and well exprefs'd in the fpecific difference.

cyarus 2.

CENTAUREA calycibus ferratis, foliis linearibus integerrimis, infimis dentatis. $S p$. pl. $128 \mathrm{~g}$. (Ger. em. 732.f. 2. Pet. berb. t. 22. f. 4. Moris. kift. $\int .7 . t .25 \cdot f \cdot 4$. Blackwell t. 270.)

Blue:- 
Blue-bottles. Angils.

Blue bonnets: Scotis auftral.

In corn fields not uncommon. $\odot$. VII.

The whole plant is flightly cover'd with a corton down : the ftalk is a yard high, ereet, hard, angular, and branch'd towards the top: the lower leaves are either indented, or pinnatifid, the extreme fegment being largeft and elliptical: the upper ones are narrow and linear: each branch is terminated with a fpecious blue flower: the fcales of the calyx are triangular, of a pale green, or whitin colour, their edges fufcous, torn or ferrated, and ciliated with white hairs: the barren florets which compofe the rays of the flower, grow horizontal, are commonly nine in. number, remarkably large, obliquely funnelfhap'd, and cut into fix, feven, or eight broad ferratures at the rim. The filaments below the Antbere are furrounded with a hairy ring. The ftyle is barb'd beneath the ftigma.

The flowers are received as an ornament in the garden, and vary much in colour, being not only blue, but white, purple, flefh-colour'd, and variegated.

The neutral florets infufed in water, or any fpirituous liquor, give it a beautiful blue colour, which being mixed with an acid, turns red, with an alkali green : a fine colour is alfo prepared from them for the ufe of painting, by drying them firft into cakes, in a hair-fieve in an oven, after the manner of drying faffron. See Gentleman's Magazine, 1748 , March. 
The Swedes mix them with tobacco, but more fo: colour than tafte.

A water diftilled from them was formerly recommended in inflammations of the eyes, but is now difured.

fabioja 3. CENTAUREA calycibus ciliatis, foliis pinnat1fidis, pinnis lanceolatis. Sp pl. I2gI. (Ger. enr 727. f. 2. Pet. berb. t. 22 f. 7. Moris. bif. f. 7 . 4. 26. Jig. tertia ordinis Juperioris)

Great Knapweed or Matfellon. Anglis.

In barren paftures and corn-fields, but not very common. We obferved it amongft the corn in the Cars of Gourie, \&rc. 2. VII. VIII.

The ftalk is a yard high, erect, hard, furrow'd, and branch'd : the leaves are firm, fmooth, or nightly hairy, all pinnatifid, the lobes obturely lanceoiate and dented: the flowers are purple, fpecious, and terminate the branches on long, naked peduncles: the fcales of the calyx have ciliated, fufcous margins: the neuter florets in the rim of the flower are quadrifid and quinquefid, from 20 to 22 in number, and form 3 handfome crown.

It varies fometimes with white fowers. The feeds are a winter food to imall birds. 
SYNGENESIA : POLYGARIA NECESSARIA. 504

\section{POLYGAMIA NECESSARIA.}

\section{FILAGO. Gen. pl. 995.}

- Recepi. nudum. Pappus nullus. Cal. imbricatus. Flofcrli feminei inter fquamis calycis locati.

germanica I FILAGO panicula dichotoma, foribus rotundatis axillaribus hirfutis, foliis acutis. $S p . p l$. I 31 I. (Ger.emac 642.f. 10. Pet. berb. t. 18. f. 9 हु 10. M.ris bift. f. 7.t. I1. f. 10.)

Childing Cudweed. Anglis.

In corn-fields and barren grounds not uncommon. $\odot$. VII. VIII.

This plant grows erest, and varies from fix to twelve inches in height: the whole covered with a downy fubftance like cotton. The principal Atalk is properly undivided, and terminated with a clofe globular head of flowers : but the branches which grow afterwards from its fummit, in the more adult plant, are widely dicho. tomous, and then all the fphrules of flowers, except thofe which terminate the branches, become feffile and axillary. The leaves are nu. merous, linear and acute, growing without order, and nearly ereet, having their fides preffed a little towards the ftalk and branches. Each. Plower in the fphrule has a pyramidal caljx with five angles, which calyx confints of imbricated, acute, fufcous, thining fcales with yellowith edges. Two or three hermaphrodite yel. 
lowinh florets occupy the difc of the flower, which are tubular, quadrifid at the rim, and barren: but the female florets are numerous and fertile, very nender, bifid at the rim, and grow between the fcales of the calyx. The feeds are all crowned with pappus or down, but fo extremely fugacious as to pafs unreg arded by Linnaus.

The plant has a drying aftringent quality, the powder and decoction of it have fometimes been ufed with fuccels in Diarrhæas and dyfenteries. The farmers in Englond were accultomed formerly to give it their cattle to reftore the faculty of chewing their cud, whence it acquired the Engli,is name of cudweed.

mottama 2. FILAGO caule fubdichotomo erecto, floribus conicis terminalibas axillaribufque. Sy/t. nat. 330. Sp.pl. I3I1. (Ger. cm. 641.f. 9. Moris hift. f. 7. t. I1. f. 3. Pet. berb. t. 18.f. 1 I. melior.)

Leaft cudweed. Anglis.

Upon wails and other dry barren places. We obferved it in Stratb-Tay, \&cc. $\odot$ VII. VIII. The plant is five or fix inches high, erect, and covered with the like cotton down as the preceding. The leaves are numerous, linear, and acute. The flowers grow from two to four in a clufter, at the angles and extremities/ of the branches. The calyx is pentagonal, furrow'd, of a whitih green colour, fhining at the top, and 
SYNGENESIA : POLYGAMIA NECESSARIA. 503 and includes florets of both fexes. The fmallnefs of the clufters, and the few Howers which compofe them, will readily diftinguilh this plant from the preceding. 


\section{MONOGA M I A.}

JASIONE. Gen. pl. 1005.

Cal. communis 10-phyllus. Cor. 5-petala, regularis. Caps. infera, bilocularis.

montana ! JASIONE. Sp. pl. 1317. (Ger. emac. 723. f. I2, Moris. bift. S. 5. t. 5.f. $4^{8}$. Pet. berb. t. $55 \cdot f$. 2. Colusnn ecpbras. p. 226. t. 227. Las. Pruff. t. 73. bon.)

Hairy Sheep's Scabious. Scabious Rampion. Anglis. In dry hilly paltures, as at Cbatelberault, by $\mathrm{Ha}$ milton, and at Brodic-Caftle, in the line of Arran, \&c. ๑. VII.

The ftalk is about a foot high, erect and branch'd.

The leaves are numerous, growing without order, elliptcal, roughly hairy, waved on the edges, fometimes nightly ferrated, but oftner intire. The branches are deftitute of leaves a good way downwards, and are terminated with nearly hemifporical heads of blue flowers, which are fubrended by a common calyx, confifting of about ten oval-lanceolate leaves. Each horet has alfo its own proper quinquefid calyx, fupported by a peduncle. The floret itfelf is pentapetalous, the petals Jinear, acute, and connected together at their bafe. The capfule is roundifh and angular, crowned with the calyx, and has two or three cells, containing many 



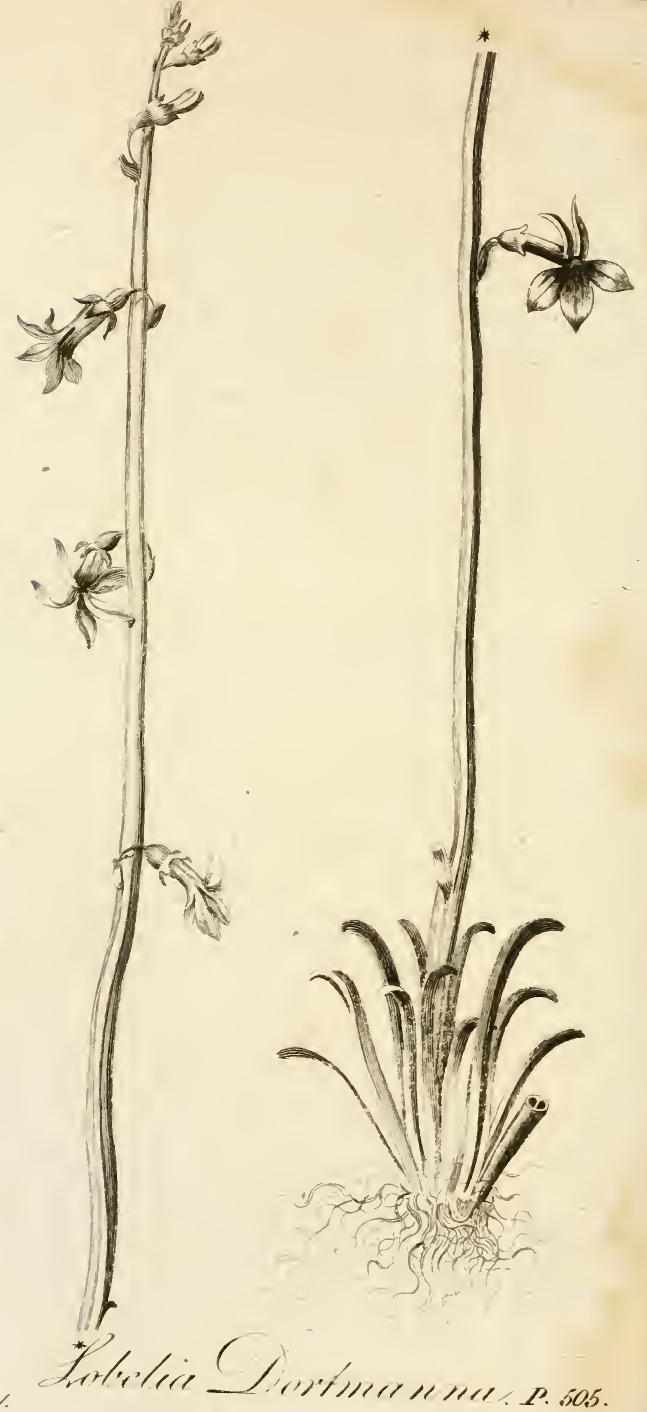


oval brown fhining feeds. The florets in the centre of the head are often abortive. The young plants yield a milky juice.

Linnous fays that bees are fond of the flowers.

\section{LOBELIA. Gen. pl. 1006.}

Cal. 5-fidus. Corolla I-petala, irregularis. Caps. infera, 2-s. 3-locularis.

dortmannas LOBELIA foliis linearibus bilocularibus integerrimis, caule fubnudo. Sp.pl. 1318. (Pet. berb. $t$. 67, f. 7. Oed. Dan. t. 39. E fig. noft.)

Water Lobelia, Water Gladiole. Anglis.

It is very frequent in almoft every frefh-water loch in Scotland, and particularly in the highlands and weftern ifles, growing near the edges of the water. 4. VII. IX.

'The leaves fpread in a circle about the root, and grow under the water : they are about two inches long, linear, flattirh, and generally a little reflexed at the ends, and if cut tranfverfely are found to confitt of two longitudinal and paral. lel hollow tubes, which is very remarkable: the ftalk is ereet, round, hollow, from a foot to two feet high, and almoft naked : the flowering part raifed out of the water. The flowers are white, with a night tinge of blue or purple, eight or ten in number, growing in a thin fpike : each is monopetalous and ringent, divided into five fegments at the rim; the two upper fegments narrow, lanceolate, and a little reflexed: the three others broader and oval: the capfule is obtuifely 
obtufely oval, and confifts of two cells, containing mary fmall feeds. The whole plant is lactefcent.

\section{VIOLA. Gers. pl. 1007.}

Cal. pentaphyllus. Cor. pentapetala, irregularis, poftice cornuta. Caps. fupera, trivalvis, uniloctJaris.

\section{* Acaules.}

aluptis z. VIOLA acaulis, foliis reniformibus. $S p \cdot p l$. 1324 . (Pet. berb.t. 37.f. 5. Moris. bift. S. $5 . t .35 \cdot f$. 5. Oed. Dan. t. 83. opt.)

Marn Violet. Anglis.

In bogs and marhy grounds not unfrequent. 4. V. VI.

The floral fialk is either round or femicylindrical, about three inches high, dertitute of leaves; but furnithed in the middle with two lanceolate ciliated Bractee, and terminated with a fingle fmall flower of a pale blue or flefh colour: the two uppermoft petals are of an uniform colour without ftreaks : the fide ones have one or two purple freaks, and the lowermoft has about feven branched ones: the fpur or heel of the flower is fhor: and blunt, and produced but 2 very little behind the calys. The leaves, which are all radical, are fmooth and tender; kidney. itaped, and crenated on the edges. The root creeps, and is covered with many foliaceous fcales.

Y. acaulis, 


\section{SYNGENESIA MONOGAMIA.}

odorata 2. V. acaulis, foliis cordatis, ftolonibus reptantibus.

Sp.pl. 1324. (Ger. em. 850.f. 1.2. Blackwell t. 55. Oed.Dan. 2. 309. opt.)

Sweeet Violet. Anglis.

Sail-chuach. Gaulis.

Under hedges and on banks by the fides of rivulets. 24. III. IV.

The root throws out creeping runners : the leaves are heart-rhaped, crenated, and pubefcent underneath: the peduncles radical: the flowers extremely fragrant, and are either of the colour which the Name of the plant imports, or white.

The flowers are efteemed to be anodyne, cooling and emollient. A fyrup made of them proves an agreeable and ufeful laxative to children : the leaves are alfo emollient, and the feeds diuretic.

The blue tincture of violets is a common teft of all acid and alkaline fubitances, for being mix'd, the firt will always turn it of a red colour, the latter of a green.

The Turks make a violet fugar of the flowers, which diffolved in water makes their favorite liquor, called Sorbet. HafJelquife's Voyage, $p$. 254.

The Caledenian ladies formerly uied them as a cofmetic, as appears from the advice given it the following Gaulic lines:

Sail-chuach as bainne ghabhar.

Suadh re $t$ aghaidh, 
'Scha 'n'eil mac ri'air an dominan

Nach bi air do dheadhai'.

Thus tranlated,

"Anoint thy face with goat's milk in which vio" lets have been infuied, and there is not a young "prince upon earth who would not be charmed "with thy beauty."

Caulefenies.

canina 3. VIOLA caule adultiore afcendente, foliis oblongocordatis. Sp, pl. I 324 . (Ger. em. $85^{1}$. f. 6. Pet. berb t. $37 \cdot f .4$. Moris. bift. .5. 5. t. 7.f. 2. Barrel. ic. 695. Rivin. t. 117.)

Dog's Violet. Anglis.

In woods, paftures and heaths frequent. 24.IV. V. The leaves are pubefcent at their firft eruption, but afterwards fmooth: the floral ftalks, at firft fowering, appear to be radical; afterwards the plant becomes caulefcent and branched, with leaves and peduncles growing out of the ftalk: the $f$ ipula are dented with long cilia : the flowers are without fcent, of a bluin colour, with a thick white obtufe NeEtarium, or fpur.

\section{*** Stipulis pinnatifidis; ftigmate urceolato.}

strandifora VIOLA caule triquetro erecto, foliis cbiongiufcu4. lis, Atipulis pinnatifidis. Syft. nat. p. $5^{8} 5$. Mantiff. p. 120. (Barrel. ic. 691 $\mathcal{O}^{2} 692$. Haller. Ftirp. Holvet.p. 243.n. 566.t.17. \& varietas caulefcens. Moris.bif. f. 7.t. 7.f. I I. Pet. berb.t. 37.f. 10. Rivin. b. In.) 
Great yellow Violet. Anglis.

On hilly paftures and mountains not unfrequent; as on Brougbion-beights, in Treddale, and on the Pentland-bills, about tivo miles fouth of Faft= Caftle, at Crawford-Gobn, near the Lead-bills, in Lanerkfbire, and with a purple flower on Mal!-

- gyrdy, in Breadalbane, \&c. 2 . VI-VIII.

The plant at its firft flowering is dwarfinh, but arterwards becomes caulefcent, ereet, and about fix inches high: the leaves are oval, pubefcent, and have generally eight diftant obtufe ferratures in the margin : the ftipule are very large, and either trifid, quinquefid or pinnatifid : the leaves of the calyx are ferrated behind: the flower is generally much larger in proportion than in the other fpecies, and is commonly of a yellow colour, the baie of the petals being freak'd with dark purple rays: fometimes it varies with a purple flower, the petals having yellow ungues, and ftreak'd as before : we have alfo feen it with two of the petals purp?e, and the reft yellow. The fpur is longer than the calyx, and almof itrait, but not above one-third part fo long as the petals.

aricolor 5. VIOLA caule triquetro diffuro, foliis oblongis incifis, ftipulis pinnatifidis. Syft. nat. p. $5^{8} 5$. (Ger. em. 854.f. I. Pet. berb. t. 37.f. 8. g. Moris. bif. $\int .5 \cdot t \cdot 7 \cdot f \cdot 8.10$. Rivin. t. 120. Blackwell t. 44.) 
Panfies, or Heart's-Eare. Anglis.

Sail-chuach. Gaulis.

In corn-fields frequent, $\odot$. V-IX.

The ftalk is weak, proftrate and branched: the leaves are elliptical; the fripule pinnatifid at the bafe, the extreme lobe being oval, obture, and a little ferrated, refembling a fmall leaf. The peduncles are compreffed. The Bractea haftate, with two obfolete dents on each fide at at the bafe. The flower varies greatly, the petals being often of two, and fometimes of three colours, a dark velver-purple, yellow and blue, Areaked at the bafe with blackin veins. This elegant colouring has gained it a place in almoft every garden. In iffwild ftate however, it is feldom fo very fpecious, the flower being commonly fmaller, the two upper petals of a whitifh colour, and the lowermoft yellow ftreaked with dark lines; or elfe the whole flower of a pale blue colour.

In $W$ arwick/bire and Worcefter/bire this plant is called by the common people Love in Idleness, and therefore is doubtles the herb to which the inventive fancy of Sbakefpear attributes fuch extraordinary virtues in the perfon of Oberon king of the fairies, in the Midfummer Nigbt's Dream. Act 2. fc. 2.

Yet mark'd I where the bolt of Cupid fell, It fell upon a little weftern flower,

* The poet calls it a little weftern flower, becaufe the fcene of his play is fixed at Atbens, which is eaftward of Great-Britain. 
Before milk-white, now purple with love's wound; And maidens call it Love in Idleness.

Fetch me that flower, the herb I hew'd thee once : The juice of it, on leeping eye-lids laid, Will make or man or woman madly doat

Upon the next live creature that it fees. 


\section{GYNA N D R I A. \\ $C L A S S I S X X$. \\ G Y N A N D R I A. \\ D I A N D R I A.}

ORCHIS. Nectarium corniculatum. SATYRIUM. Nectarium fcrotiforme. OPHRYS. Neidarium fubcarinatum. SERAPIAS. NeElarium ovatum fubtus gibbum.

\section{P O L Y A N D R I A.}

AR/UM. Spatha. Cal. nullus. Cor. nulla. Stam. fupra piftilla.

zOSTERA. Folium. Cal. nullus. Cor. nulla. Sem. alterna nuda.

\section{I A N D R I A.}

ORCHIS. Gen. pl. 1009.

Nectarium corniforme pone florem.

* Bulbis indivifls.

bifolia 1. ORCHIS bulbis indivifis, nectarii labiø lanceolato integerrimis; cornu longifimo, petalis patentibus. Sp. pl. 133r. (Ger. em. 211 . f. 1. 2. Pet. berb. t. 68. f. 11. 12. Vaill. Paris. t. 30. f. 7 . Sequier. Veron. t. I $5 . f$. 10. Haller. Stirp. Helvet. $1285 . t, 35$. bona. Oed. Dan.t. 235. optima.) Butterly Orchis. Anglis.

In woods and in dry expofed paftures not uncomxion, as about Aucbendenny, \&rc. 24. VI. 


\section{GYNANDRIA DIANDRIA.}

The root confifts of two oval folid bulbs, crowned with thick flethy fibres: the ftalk is angular, from a foot to eighteen inches high. The leaves are radical, oval, two or three inches wide, and generally two in number, but fometimes three. Thofe on the ftalk are fmall, and refemble lanceolate ftipule. The flowers are white, with a night mixture of green, and grow in a long lax spike. The petals are diftended fo as clearly to exhibit the ftamina to open view : the lip is long narrow and linear : the nectarium or fpur is tubular, a little compreffed, about an inch long, and contains a clear liquor. The cntbere are yellow, and diftant from each other: the flowers in the morning and evening have a fweet honey-like fmell.

8. There is a variety of this orchis with a fmaller flower and horter ftalk, which bloffoms later, and grows in dry paltures, called the leffer butterfly orchis.

The roots of this, and molt of the other fpecies of orchis, are efteemed to be aphrodifiacal.

pyramidalis ORCHIS bulbis indivifis, nectarii labio bicorni trifido æquali integerrimo, cornu longo, petalis fublanceolatis. Syft. nat. 589. Sp.pl. 1332. (Raii Syn. p. 377.t. 18. bon. Seg. Veron. t. 15. f. 11. flos. Vaill. paris. t. $3^{1 .} f \cdot 3^{8}$. flos. Rivin. t. 14. Hall. bift. Helvet. 1286. $t$. 35.)

Purple late-flowering Orchis. Anglis. 
In dry paftures, but very rare, as near Kiloran, in the ifland of Colonfa. 4. VII.

The flowers of this grow in a fhort clofe conical fpike, and are of a bright purple colour, without any fpots, making an elegant appearance. The three upper petals are clofe together, the fide ones expanded, the lip is divided into three oval fhort intire fegments, nearly equal; at the bafe of which are two parallel longitudinal auricles. The fpur is cylindrical, Nender, and longer than the capfule. The ftalk is furnifhed with five or fix lanceolate acute leaves: The Bractee are lanceolate, coloured, and of the length of the germen.

morio 3.

ORCHIS bulbis indivifis, nectarii labio quadrifido crenulato, cornu obtufo afcendente, petalis obtufis conniventibus. Syft. nat. 589. Sp. pl. 1333. (Ger. em. 208.f. 2. Vaill. par. t. 31.f. 13. 14. flos. Seg.Veron. t. 15.f. 7. flos. Kivin. t. 13. Haller. bift.n. 1282. t.33.)

Female Fool-ftones. Anglis.

In paftures and moift woods frequent. 24. VI.

The ftalk is about eight inches high: the fpike confints of few flowers, feldom more than I2, generally of a purple colour, but fometimes fien-coloured, or white: the petals all clofe together, forming a vaulted arch over the famixa. They are obtufe, and always Atreaked longitudinally with green lines : the lip of the nectarium is trifid and fpotted in the middle, the lateral 
lobes are nightly crenated and reflex'd; the central one is crenated and nightly bifid: the fpur is about the length of the germen, obtufe at the end, emarginated, and a little afcending: the Braitee are of the colour of the flower, and abour the length of the germen.

masckla 4. ORCHIS bulbis indivifis, nectarii labio quadrilobo crenulato; cornu obtufo; petalis dorfalibus reflexis. Sp.pl. 1333. Syft. nat. 590. (Ger. em. 208.f. I. Seg.Veron.t. 15.f. 6. flos. Vaill Paris. t. 31.f. 11, 12. Rivin. t. 21. Blakwell t. 53. Oed. dan.t. 457. Haller. bift.1283.t.33.opt.)

Male Fool.ftones: Anglis.

In woods frequent, as in Logton-Wood, near Dalkeith, \&c. 4. VI.

The ftalk is about a cubit high : the leaves broad, flat, and gloffy, and generally ftained with blood-colour'd fpots: the flowers grow in a long thin fpike, of a fpecious purple colour: the exterior petals are oval and acute; the two fide ones fold back, ftand erect, and have no green itreaks: the lip of the nectarium is crenated and trifid, and the middle lobe bifid, but is lengthened out beyond the fide ones. In thefe refpects it differs from the preceding.

The fpikes of thefe flowers are the Long-Purples, or dead men's fingers, which helped to compofe poor Opbelia's garlands : 
There with fantaftic garlands did the come, Of crow-flowers, nettles, daifies, and long purples, (That liberal thepherds give a groffer name, But our cold maids do dead men's fingers call them.) Hasilet, aft 4 .

The falep of the thops is made, for the moft part, of the roots of this Orcbis; for this purpofe the largeft and plumpeft bulbs muft be gathered, fkinned, and boiled over a gentle fire for half an hour; afterwards they muft be ftrung upon a thread, and hung up in the thade till they are dry. Thefe, reduced to powder, are the falep, efteemed as a reftorative and aphrodifiac, and reckoned ferviceable alfo in dyfenteries, and phthificky complaints.

\section{* Bulbis palmalis.}

Talifulia st ORCIIS bulbis fubpalmatis rectis, nectarii cornt conico; labio trilobo lateribus reflexo, bracteis Aore longioribus. Sp. pl. $1333_{4}$. (Ger. em. $226 . f$. 3. EO 222. f. 3. Vaill. paris. t. 31.f. 1, 2, 3, 4, 5. flores. Bilakwell. t. 405. Oed.das. t. 266. opt. llalier. bift. $1279 \cdot$ t.32. bona.)

Male handed Orchis. Anglis.

In marthy grounds and bogs common. 4. VI.

The bulbs are divided into two or three fingers, which are not divaricated, but run directly downwards: the leaves are broad, and commonly without fpots, but are fometimes obfcurely It ained: the ftalk is a foot or more high, ftriated 


\section{GYNANDRIA DIANDRIA.}

and fiftular: the fpike is conico-cylindrical : the flowers are commonly purple, but fometimes red or white, intermixed with many broad lanceolate Brafiea, which are longer than the flowers: the two fide petals turn back, and ftand almoft upright, the others connive toge. gether: the lip is divided into three obfcure lobes, ferrated on the edges, and marked with purple lines and fpots: the middle lobe is fhort, and the fide ones reflexed: the fpur is conical, a little incurv'd, and fhorter than the germen.

*aculata 6 . ORCHIS bulbis palmatis patentibus, nectarii cornu germinibus breviore, labio plano, petalis dorfalibus patulis. Sp. pl. 1335. Sygt. nat. sgo. (Ger. esm.220.f. 2. Vaill. paris. t. 3 I. f. 910. Rivin. t. 8. E 11. Hall, bift. 1273. t. 32.bona.) Female handed Orchis. Anglis. Balderry. Scotis. An ùrach-bhallach. Gaulis.

In paftures and heaths very common. 4. VII. The bulbs are divided into three or or four divaricated fingers : the leaves are almort always fpotted, and narrower than in the preceding fpecies: the ftalk is a cubit high, and folid: the fpike is cylindrical, and the flowers commonly of a pale blun, or almoft white colour, marked with many fpors and purple lines: the fide petals ftand open, and almoft erect: the lip is plane, crenated, and divided into three lobes, the mid. dle one narroweft, and generally acute and en- 
tire: the fpur is obtufe, and a little fhorter thais the germen: the Braktea are not longer than the flowers, and much narrower than in the preceding kind.

3. A variety of this, with fpotlefs leaves, found in Aucberdenny woods, was communicated by Dr. Parfons.

conopsea 7 . O. bulbis palmatis. nectarii cornu fetaceo germinibus longiore; labio trifido, petalis duobus patentifimis. Sp. pl. 1 335 . Syft.nat. 590. (Ger. erm. 227. f. 5. Rivin. t. I1. Vaill. paris. t. 30. f. 8. Hall. bift. 1287. t. 29. bona. Oed. Dan.t. 224. opt.)

Long-fpur'd fweet handed Orchis. Anglis.

In paftures not unfrequent, as in thofe eaftward of Auckendenny, and about Comrie, near Creif, \&c. 2?. VI.

The ftalk is a cubic high, the leaves long and narrow, their fides a little compreis'd: the flowers grow in a long cylindrical fpike, generally of an uniform purple colour, but fometimes white: the fide petals are widely expanded, the reft connive: the lip is divided into three obture and nearly equal fegments, the fide ones fometimes nightly ferrated, the middle one quite entire: the fpur is very Render, curv'd, and about three times the length of the fide petals : the Bratiee are lanceolate, and rather longer than the germen: the flowers are fweet fcented. 


\section{SATYRIUM. Gen. pl. ioro.}

Nectorium fcrotiforme f. inflato-didymum pone florem.

viride 2. SATYRIUM bulbis palmatis, foliis oblongis obtufis, nectarii labio lineari trifido, lacinia intermedia obfoleta. Sp. pl. 1337. (Vaill. paris. t. 31.f. 6, 7, 8. Loes. Pruss. 182 t. 59. Seg. veron. p. 133. t. I 5.f. 18. flores. t. 16. f. I8. plant. Haller. hijt. 126g. t. 26. Oed. Dan.t. 77 , opt.)

Frog Satyrion. Anglis.

In dry hilly paftures not uncommon. We obferv'd it in Fura, near Mr. Campbell's; in Ifla, Colonse, and Sky, \&x. 4. VI. VII.

The ftalk is about fix or eight inches high: the lower leaves oval: the flowers are of a greenifh, and fometines of a dull red colour, growing in a thin fpike, two or three inches long: the bracto are lanceolate, and longer than the germen: the petals all connive, and form a galea over the ftamina: the lip is plane, ligulate, of the length of the germen, wideft at the extremity and bifid, with a hort triangular mucro in the middle, between the fegments: the fpur is very fmall, oval, didymous, and about 1-12th of an inch long.

a.bidum 3 . SATYRIUM bulbis fafciculatis, foliis lanceolatis, nectarii labio trifido acuto, lacinia intermedia obtufa. Sp.pl. 1338. (Micbel. gen. t. 26.f. A. B. C. Hall. bift. 1270. f. 26 . Oed. dan.t. I I 5.) 
White Satyrion. Anglis.

In dry mountainous paftures not very uncommon. We obferved it at the Iflbmus of Tarbat, in Canlire, in Argylefire; in the ine of Arran, near Loch-Ransa, \&c. in Fura, on a dry hilly pafture near Mr. Campeli's, in Iflh, Colonfa and Skye, in fimilar places. 24. VI. VII.

The root confites of fix or eight long tap-hap'd folid radicles: the ftalk is about ten inches high: the fpike is about three inches long, cylindrical and thick fet with numerous fmall whitifh deflexed flowers : the Bractea are lanceolate, and rather longer than the germen: the petals are white, and connive into the form of a galea, the fide ones longent: the lip of the nectarium is green, and divided into three acute fegments, the middle one largeft : the fpur is white, about half the length of the germen, obtufe at the end, and recurved, but not didymous, as the generic chazacter requires.

SATYRIUM bulbis fibrofis, foliis ovatis radicalibus, floribus fecundis. Sp. pl. 1339. (Ger. em. 227. f. 4. Loes. priff. 2 10. t. 68. Haller. bij. 1395. tab. 22. Trew. Lit. Norimb. cisac. 1735. kebd. 52. p. 40g. t. 6. .5. 7. bona. E. jg. noft.) Creeping Satyrion. Anglis.

In old mofiy woods, but very rare. We found it growing amongit the Hypna, in an old Soady moift hanging birch wood, called, in the Erfe lang:uage, Ca-bue, or Yellow-bill, tacing the howe 



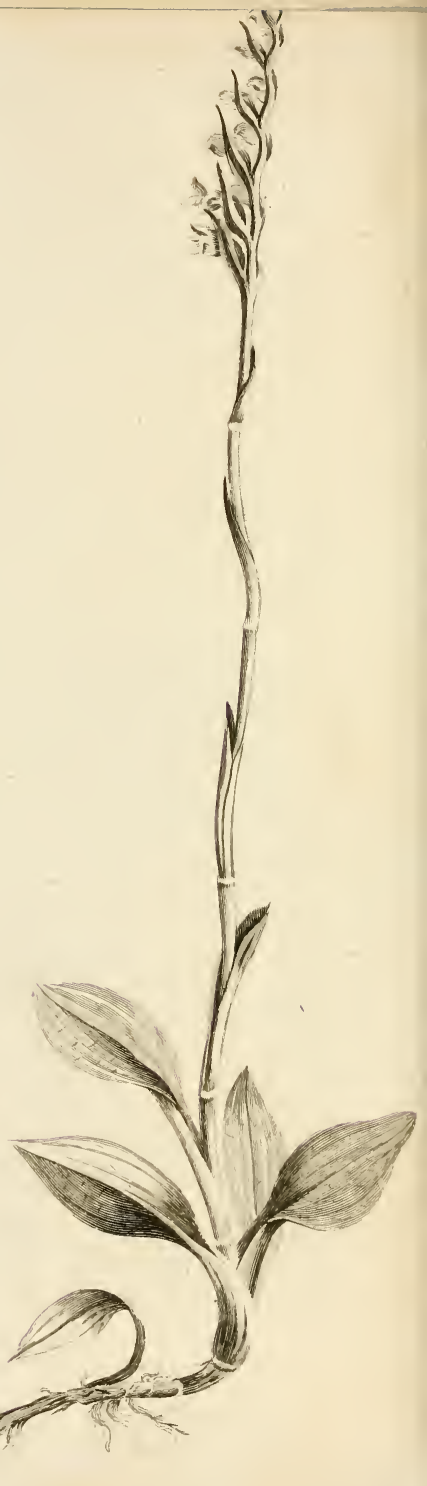


of Mr. Mackenzie, of Dundoneld, about two miles from the head of Littie-Loch-Broom, on the weftern coaft of Kafs. Hive. It has alfo been found in a wood oppofite to Moy-ball, on the fouth fide of the road to Inverness, as we have been informed by Dr. Hope, 4. VIII.

The roots are round, annular, and branched, and creep under the mofs, throwing out new runners or thoots: the ftalk is about a foot high, erect, and hairy, efpecially towards the top: the leaves are oval, nervous, have broad foliaceous pedicles, and grow near the bafe of the ftalk. Thofe nerves are generally five in number, but fometimes feven, branched from the fides and reticulated with veins which are of ten of a fufcous colour. The flowers are a little hairy, or pubefcent, whitinh or ftraw-coloured, and grow in a fpike, from fifteen to twenty in number, rifing from one fide of the ftalk, but turning round, and looking to the orher fide. The bracfece are lanceolate, longer than the germen, and of the fame colour as the flowers: the pe tals ate three, pubefcent, and glew'd, as it were, together, fo that they cannot be feparated without being torn. The lip is lanceolate, and terminated behind with a gibbous boat-fhaped neitcrium, which makes this plant belong more properly to the genus of Eeregiss. Lin. 


\section{OPHRYS. Gen. pi. 1011.}

\section{Neciarium fubtus fubcarinatum.}

* Bulbis ramofis.

Nïlus avis OPHRYS bulbis fibrofo-fafciculatis, caule vaginato aphyllo, nectarii labio bifido. Syft. nat. 592. Sp.pl. 1339. (Ger. cm. 228. f. 1. Rivin. t. 7 . Tournef. Inft. p. 43 8. t. 250. Haller. bift. Iego. ¿37. bona Oeder. Dan.t.181. opt.)

Bird's Neft Opbrys. Anglis.

In woods, but not common, as in Auchendenny woods, ten miles from Edinburgb, towards Lanerk. Dr. Parfons. And in the woods at Finla. rig, at the head of Locb-Tay, in Breadalbane, \&c. Mr. Stuart, 4. VI.

The root confifts of a bundle of Aefhy, brittle cylindrical fibres, which grow fideways out of the bafe of the ftalk, at right angles. The whole plant is, of an uniform pale brown, or fuillemort colour: the ftalk is erect, firm, brittle, from a foor to a cubit high, deftitute of leaves, but furnifhed with fufcous fcales, or fipula, theathing the ftalk: the flowers are numerous, of the fame colour with the flalk, and grow in a thick cylindrical fpike, thineft at the bafe: the Bracle.e are hardiy folong as the germen: the petals all connive: the lip has an oval concavity at the bafe, and is femibifid at the end: the fegments recede widely from each other, and are little fiarer than the germen. 



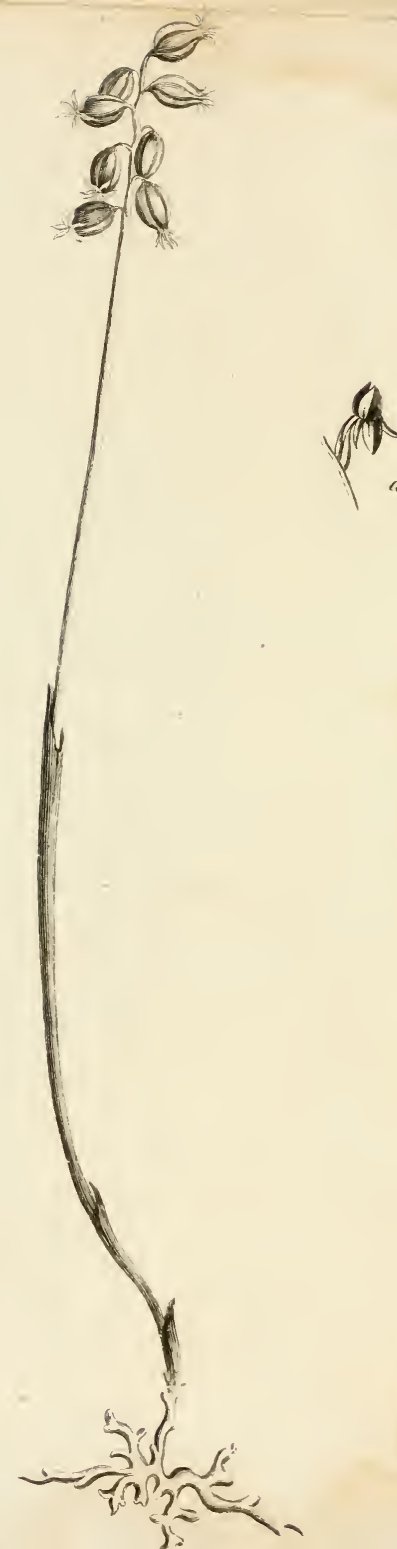


corallorbiza ORPHYS bulbis ramolis flexuofis, caule vaginato, 2. aphyllo, nectarii labio trifido. Syjt. nat. 592 : Sp.pl. 1339. (Ger. em. 158.5. f. 2. Haller. bif. 1301. t. 44: Oed. Dan. t. 451 . E fig. roft.)

Coral-rooted Opbrys. Anglis.

In marhy woods, but very rare. We obferved it only in one place, and there fparingly, viz. in a moift hanging wood, on the fouth fide, near the head of Little-Lock-Broom, on the weftern coaft of Ross-ßBire. 24. VI. VII.

The root confifts of white, thick, fucculent, obrufe -fibres, branched like coral.' The italk is about fix or eight inches high, and has no other leaves than theathing fipule. The flowers grow in a thin fpike, about eight or ten in number, verging a little to one fide of the ftalk, and fubtended each by an oval-lanceolate greenifh Bractea. The upper petals are green, oval lanceolate, and connive in the form of a femicylindric Galea. The lateral petals are patent, whitin, and ftreaked with a green line. The lip is ovallanceolate, white, and freaked with two green lines, forming an acute angle. The flower is furnined with four famina, two in each cell. The capfules nod.

oraia. 3. OPHRYS bulbo fibrofo, caule bifolio, folis ovatis, nectarii labio bifido. Sp.pl. 1340. (Ger. em. 402. f. I. Pet. berb.t. 70. f. 10. Rivin. t. 7. Oed. Dam.t. 137. bom. Haller. bifi. 1291, t. 37: opt.) 
Great Twayblade. Anglis.

in woods and moift paftures not uncommon. $\%$. VI.

The falk is a cubit high, downy, and furnifhed only with two oppofite, broad, obtufely oval, nervous or plantain-like leaves, which grow nearly in the middle between the root and the botton of the fike; the bafe of one of thefe leaves embracing the bafe of the other. The fpike is five or fix inches long, diftinctly tet with thirty or forty yellowin green flowers. The lip of the flower is nearly linear, femibifid, and about twice the length of the germen, and defcends perpendicularly : the fegments are obtufe, the germen is thick, oval, and furrowed with fix lines.

cordata 4. OIHRYS bulbo fibrofo, caule bifolio, foliis cordatis. Sp. pl. 1340. (Pet. herb. t. 70.f. 11. Moris. S. 12. t. 11.f. 4. Haller, bijt. 1292. t. 22. opt.)

Little 'Twayblade, with heart-Rhap'd leaves. Anglis. In marhy places by the fides of rivulets, on the highland mountains in many places, as on Bina-grion in Strath, two miles above Mackennon's caltie, in the Jfle of Skic; on the mountains in Rojs-ßBire, about Little Locb-Broon, and in Breadalbane, ixc. 2i. VII.

The roo confift: of many long round fibres: the ilalk is about fic eight inches high, and the whote flut in of a tander and delicate texture. 
The leaves are only two, fmooth, oppofite, and heart-haped, and about half an inch wide at the bafe: the flowers grow in a thin fpike, ten or twelve in number; of a green colour, often turning red in decay: the petals are lanceolate, and ftand wide open : the lip is femibifid, longer than the germen, and has a dent on each fide at the bafe, which is wanting in the preceding fpecies: the fegments are acute, and often of a dark red colour.

\section{** Bulbis rotundis.}

paludosa 5. OPHRYS bulbo fubrotundo, fcupo fubnudo, pentagono, foliorum apicibus fcabris, nectarii labio integro. Sp.pl. 1341. (Pluk. alm. t. 247. f. 2. Pei. herb. t. 70, f.12)

Marh Opbrys. Anziis.

We have received information that this has been found in fome marfhes near St. Andrews, bur we do not affirm it from our own knowledge. 2f. VIII. IX.

The root confifts of one, and fometimes more bulbs growing one above another, with fibres thooting from their bafe: the falk is about a finger's length, and has two or three alternate oval-lanceolate leaves near its bafe, having their inner margin towards the top ferrulated and rough to the touch: the flowers are numerous, twenty or thirty in a fpike, of a yellowifh green colour : the fide petals fold back and ftand erect: the lip of the neitarium is lanceolate and entire.

SERAPIAS 


\section{SERAPIAS. Gen. pl. 1012.}

Neezariun ovatum, gibbim, labio ovato.

lntifolic \& SERAPIAS bulbis fibrofis, foliis ovatis amplexicaulibus, foribus pendulis. Syft. nat. 593. Scop. Carn. I128. (Ger. ein. 442. f. I. Rivin. t. 6. Haller. bift. 1297 t. 40. opt.)

Broad-leav'd Helleborine. Anglis.

In woods, but not very common, as at Cbatelberault, near Hamilton. Dr. Parfons. And in the wood of Comrie, in Stratbearn. Sibbald, 24. VII. VIII.

The ftalk is erect, firm, nightly villofe; a cubit or more high, and furnished with fix or eight nervous oval leaves, the lowermoft broad and obtufe, the uppermoft narrower and lanceolate, degenerating gradually into fipula. The $\mathrm{f}^{\mathrm{a}} \mathrm{ike}$ is about fix inches long, confifting of nearly $30^{\circ}$ nodding flowers, which often lean to one fide of the ftalk: the bractere are longer than the flowers : the germen is downy, pendulous, of a pear-thaped form, ftreaked with three elevated ridges, and fupported by a peduncle. The three upper petals of the flower are of a green colour, oval-acute form, and nightly villofe on the upper fide : the lateral ones are a little fhorter, of a more tender texture, of a white colour, with a little tinge of green: the petals connive at firf, but afterwards recede and ftand open : the neciarium is an oval cavity, moiftened with a green liquor, and furnithed with white erect 
marginal appendages: the lip is heart Maped, the end acute and deflexed, and commonly of a whitin, or a pale red colour, but fometimes this and the whole flower is of a dark red, or blood colour. The capfule is obtufely triangular, has three valves and one cell.

paluftris 2. SERAPIAS bulbis fibrofis, foliis enfiformibus, feffilibus, foribus pendulis, neetarii labio obtufo; fubferrato, petalis longiore.

S. longifolia Lin. Sy/t. nat. 593. S. paluftris. Scop. Fl. Carn. i 129 . Helleborine paluftris nofiras. Raia Syn.p. $3^{84}$ n. . . (Rivin. t. 3. Haller. bif. 1296 . 1. 39. bona. Oed. Dan. t. 267. opt.)

Marfh Helleborine. Anglis.

In rough boggy paftures and marhes, but not common. We obferv'd it in fome bogs near Duntulm caftle, in the inle of Skye. 24. VII.

The flowers grow about fifteen or twenty in a loofe fpike. The germen is villofe, and of a dark red or purplin colour. The three exterior petals are green mix'd with red, and nightly pubefcent. The lateral ones are white with a red blum : the lip hangs down out of the Hower, and is heartShap'd, obtufe, white, Mightly ferrated, and plaited on the margins, and often emarginated: the nectorium is mark'd with red lines and yellow tuberculous fpots. This is enough to diftinguinh it from the preceding, and the whole habit of the plant declares it to be a different fpecies. 
grandiflora SERAPIAS bulbis fibrofis, foliis enfiformibus, flo3. ribus erectis, nectarii labio obtufo petalis breviore. Syft. nat. 594. S. longifolia. Sp. pl. 1345. (Moris. bift. S. 12. t. I1. f. 12. Haller. bift. 1298 , t. 41, bona. Oed. Dan. t. 506, opt.) White-flowered Helleborine. Anglis.

In woocis, but rare. We faw it in a wood at LochRanfa, in the ine of Arran. 24. VI.

The leaves are variable, being fometimes of an oval-lanceolate, but generally of a long-lanceolate form. The flowers are large, erect, fix or eight in a thin fpike, fubtended by foliaceous lanceolate Braciea, the lowermont of which are b:oad, and longer than the flowers: the petals are all white, and connive together : the lip of the neEtarizm is enclos'd within the petals (not pen(iant as in the preceding) and is white, ftreak'd with three yellow prominent lines. The germen is erect, and nearly feffile.

\section{POLYANDRIA.}

\section{ARUM. Gen. pl. 1028.}

Spatha monophylla, cucullata. Spadix fupra nudus, infernè femineus, medio ftamineus.

maculatum ARUM acaule, foliis haftatis integerrimis, fpa1. dice clavato. Sp. pl. 1370. (Ger. em. 834. f. 1. Moris. bift. $\int_{.} \mathrm{r}_{3}, t .5, f . \mathrm{x}$, ordinis inferioris, Blackweli't. 228, Miller ic.t. $52, f . \mathrm{I}$, bonta. Oed. Das. t. 505, opt.) 
Wake-Robin or Cuckow-Pint. Anglis.

Under hedges and in Shady places, but not fo frequent as in England. 4. V.

The root is tuberous and flefhy, with fibres grow. ing out of the bafe: the leaves are radical, haped like the barb of an arrow, fupported on footfalks, fmooth and glorfy, and often ftain'd with dark or whice fpots: the Spatbo is whitifh, deciduous, and Shap'd not unlike a hare's ear : with $n$ it is a purple club-fhap'd spadix, the bafe of which is furrounded with numerous germina, with many fefiile quadrilocular Antberce above them, and again over thefe fome roundif $P a$ pille, terminated with deflex'd hairs. The berries when ripe are fcarlet, full of juice, and contain each one or two round, hard feeds, reticulated on the furface.

The whole plant is extremely acrimonious to the tafte, inflaming the mouth for a long time afterwards; but the roots when boil'd or dry'd lofe all their acrimony, and become perfectly infipid, and being of a farinaceous quality, have fometimes been made into bread and ftarch. They are efteem'd good in aftmatic complaints, and obftructions of the Broncbia; but are rarely ufed in the prefent praetice.

\section{ZOSTERA. Gen. pl. 1032.}

Spadix linearis, altero latere fructifero. Cal. o. Cor. o. Stam. alterna. Sem. folitaria alterna. 
marina I: ZOSTERA pericarpiis feffilibus. Syft. nat. 605. Sp.pl. 1374. (Ger. em. 156g. f. 8. Oed. Dan.t. 15. opi.)

Grafs-Wrack. Anglis.

It is thrown up on the fea-coafts frequently. 4. VIII.

The leaves are long, narrow, linear, and grafs-like, theath'd with fipule at the bafe. The flowers grow on one fide of a thin flat, linear spadix, imbedded in a cavity on one fide of the leaf, at its bafe. The ftamina and germina grow alternate to each other upon the $\int p a d i x$, about ten in number of each fort.

Linneus informs us, that the humble Inhabitants of Gotbland in Sweden condefcend to thatch their houfes, ftuff their beds, and manure their land with this plant. 
$M O N O C$ E C I A.

\section{L A S S I XXI.}

\section{$M O N O E$ C I A.}

\section{MONA N D I A.}

CHARA. §̊. s.'Flos. majc. Cal. nullus. Cor. nulla.

o. s. Flos. fem. Cal. 4-phyllus. Cor. nulla.

Stignis 5-fidum. Sem. I.

ZANNICHELLIA. đ. Cal. nullus. Cor. nulla. q. Cal. I-phyllus. Cor. nulla. Pift. 4. Sem. 4.

* Callitriche verna.

\section{I A N D R I A.}

LEMNA. ô. Cal. I-phyllus. Cor. mulla.

?. Cal. I-phyllus. Cor. nulla. Styl. I. Caps. I-locularis.

\section{T R I A N D R I A.}

CAREX. A . Amentum I-florum. Cor. nulla.

9. Ament. I-florum. Cor. nulla. Styl. I. Sem. I, tunicatum.

SPARGANIUM. ô. Cal. ,3-phyllus. Cor. nulla. क. Cal. 3-phyllus. Cor. nulla. Stig. 2. Sem. I-fperma.

TYPHA. oे. Cal. 3-phyllus. Cor. nulla. 


$$
\begin{aligned}
& \text { \&. Cal. capillaris. Cor. nulla. } \\
& \text { Styl. I. Sem. I, pappigerun. }
\end{aligned}
$$

$$
\text { TE T R A N D R I A. }
$$

ERIOCAULON. ô. Cal 2-phyllus. Cor. 2-petala. q. Cal. 2-phyllus. Cor. I-petala. Styl. 2-partitus. Caps. 2cocca.

LITTORELLA. क Cal. 4-phyllus. Cor. 4. partita.

․ Cal. nullus. Cor. obfoleta Styl. longiffimus. Sem. Nux, I-locularis.

URTICA. 8. Cal. 4-phyllus. Cor. nulla. Nectar. cyathiforme.

\&. Cal. 2-valvis. Cor. O. Stigm. villofum.

Sem. I, ovatum.

BETULA. 8. Amentum 3-florum. Cor. 4-partita. 9. Ament. 2-forum. Cor. nulla. Styl. 2. Sem. I, ovatum.

\section{POLYANDRIA. (plura quam 7)}

MYRIOPHYLLUM. ó. Cal. 4 phyllus. Cor. nulla. Stam. 8.

\&. Cal. 4-phyllus. Cor. nulla. Pift. 4. Sem. 4.

CERATOPHYLLUM. 8. Cal. fub 7-partitus. Cor. nulla. Stam. 18, circiter. 
$M \subset N O E$ C $\quad \mathrm{C}$ I A.

9. Cal. fub 7-pastitus. Cor, nuila pito. 3 . Serr. 1 .

FAGUS. đ. Cal. 5-fidus. Cor. nulla. Stam. 12, circiter.

+. Cal. 4-fidus. Cor. nulla. Styl. 3. Caps. 2-fperma.

QUERCUS. o. Cal. 5 fidus, Cor. nulla. Stam. ro circiter.

?. Cal. integer. Cor, nulla. Styl, 5 . Nux coriacea,

CORYLUS. ò Amentum imbricatum. Cor. nulla. Stam. 8.

․ Cal. 2-phyllus. Cor. nulla. Styl. 2. Nux nuda.

CARPINUS. ơ. Ament. imbricatum. Cor. nulla. Stam. 10.

․ Cal. 6-fidus. Cor. nulla. Pift. 2. Nux nuda.

\section{MON A D E L P II I A.}

PINUS, \&. Cal. 4-phyllus. Cor, nulla. Stam. plurima.

9. Ament. ftrobilaceum. Cor. nulla. Pijt. 2. Nuces 2, alatæ.

$$
\text { S Y NGE N ES I A. }
$$

BRYONIA. 8. Cal. 5-dentatus, Cor. 5-partita. Filam. 3 .

?. Cal. 5-dentatus. Cor. 5-partita. styl. 3-fid. Bacsa. 


\section{L A S S I S XXI. \\ $M O N A N D R I A$.}

ZANNICHELLIA. Gen. pl. I034.

MASCULI. Cal. o. Cor. o.

FEMINEI. Cal. I-phyllus. Cor. o. Germina circiter 4. Sem, totidem.

paluftris I. ZANNICHELLIA. is pl. 1375. (Pet. berb. $t$. 6. f. 2. Pluk. alm. t. 102, f. 7. Micb. gen. t. 34 . f. I, 2, bona. Oed. Dan. t. 67.)

Horned Pondweed. Anglis.

In ditches and ftagnant waters. $\odot$. VIII.

The ftalk is greatly branched, weak, jointed, and floats in the water: the leaves are fetaceous, or very narrow and grafs-like, and grow out of the joints, fubtended by a broad theathing fitpula : the germina are a little rough, gibbous, and grow four or fix in a whirl at the joints: the anthera is fupported by a long filament, and grows by itfelf a little below the germina:

CHARA. Mantifs. pl. gen. p. 23.

Gen. pl. 1203.

MASC. Cal. o. Cor. o. Anthera germini fubjecta.

FEM. Cal. 1-phyllus. Cor. nulla. Stigma 5-fidum. Sem. I, 
w!geris I. CHARA caulibus lavibus, frondibus internè dentatis. Syft. nat. 613. Spec. pl. 1624. (Baub. Prodr. ic. p. 25. Vaill. AEt. Paris. 1719.p.23.t.3.f. 1) Common Chora, or ftinking Water Horfetail. Anglis.

In ditches where the water runs flowly not uncommon. Dr. Parfons.

The ftalks are. branched; when young fmooth, ftrait/l, and flexible; but when grown to maturity, more rigid, and incrulted with a kind of tophaceous coat, which is like fand berween the tee:h. When dry'd they are extremely brittle. The leaves are fetaceous, and grow verticillate, eight or nine in a whirl. The pericorpium is a yellow or fcarlet cruft or berry : they grow about two from the ale of each whirl, of an oblong form, replete with many black feeds. The whole plant has a ftrong difagreeable fmell like garlick or hemlock.

sispicia 2.

CHARA caulibus aculeatis capillaribus confertis. Syf. nat. 6I 3. Sp. pl. 1624. (V aill. act. Peris. 1719. p. 18.t. 3. f. 3. Pluk. alm. t. 193. f. 6. Oed. Dan.t. 154)

Prickly Chara. Anglis.

In ditches and lakes, as in Guillon-Loch, in EaftLotbion, near Lord Hyndford's. Dr. Parfons. The ftalk of this is a foot long, often fpirally ftreak'd, and together with the leaves covered with numerous fpinule, which are never feen in the 
the preceding. It is incrufted, and finells and taltes like the C. vulgaris.

flexilis 3, CHARA caulium articulis inermibus diaphanis fupernè latioribus. Syft. nat. 61 3 Sp. pl. 1624. (I ail. aEf. Paris. 1719, p. 18,f. 8, g. Dillen. 1. c. p. 59, t. 13, f.2, Scbmiedel t. 14)

Pellucid pliant Chara. Anglis.

In lakes, as in Locb-Lomond, by Dr. Parjons. In Hill-Loch, upon Creg-cbaillech, in Breadalbane, and at Comrie, a village four miles from Crief. Mr. Stuart.

7 he fialks are eight or ten inches long, filtular, tender, fmooth, flexible, and of a dull green pellucid colour: the leaves are fmooth, linear, fiftular, rointed at the end, from four to ten or awelve in a whirl, often fubdivided into two and fometimes into three forks or branches, at a joint near their extremity: the whirls grow in chefers towards the upper part of the ftalks, fecondary ones being produced from the alc of the primary : the fructifications grow either fingle or in pairs, feffile, and placed on the infide, at the ingle of the fork or branches abovementioned: thefe fructifications appear at firft like fmall round yellowin grains, which afterwards turn black, and are enclofed within a green manimarent rind or pericarpicus. 


\section{I A N D R I A. \\ LEMNA. Gen. pl. 1038.}

MASC. Cal. monophyllus. Cor. nuilia.

FEM. Cal. monophyllus. Cor. nulla. Siyl. 1. Caps, unilocularis.

trifulca I. LEMNA foliis petiolatis larceolatis. sp.pl. I $3: 6$. (Ger. em. 830, f. 2, Micbel. gen. t. 1 1, f. 5 . Roes. bift. Polyp.t. 72, fronts(piciali ad imum.) Ivy-leav'd Duck's-Meat. Anglis.

In clear ftagnant waters, as in Didifton-Lorb. Dr. Parfons. 4. VI.

The ftalk is dichotomous, filiforme, and divaricated, having a lanceolate leaf at the angle of the branches, but proliferous ones, terminating the branches; i. e. fimilar leaves growing out of their fides at right angles: where thefe three leaves are conjoin'd there thoots out a pendent radicle, with a conical papilla at its bafe.

minor. 3 .

LEMNA foliis fefilibus utrinque pianiufculis, radicibus folitariis. $S p$. pl. 1376. (Ger. em 829 . Raii Synops. I 29. t. 4, f. I. Micbel. gen. t. 11, f.

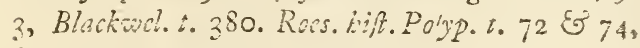
f. 12.)

The leaft Duck's Meat. Airglis.

In ftagnant Waters common. $\odot$. VII.

It produces its flowers in the Dog-days, which, together with the feeds, afford a nourifument to that wonderful animalcule called the Fivera Po- 
lyputs. Lin. Ducks are well known to be fond of this plant, and the Pbalana Lemnata of Linnaws, breeds upon it.

poyrkiza 3 LEMNA foliis fefrilibus, radicibus confertis. $S p$. pl. 1377. (Raj. Syn. p. 129. t. 4. f. 2. Micbe!. sen. $t, 1$ r. $f .1$ )

Great Duck's Meat. Anglis. In ftagnant waters. $\odot$. VII.

The leaves of this are often red underneath: it finks to the bottom of the water in the Winter feafon, and rifes to the furface again in the spring, as does alfo the preceding. It is readily diftinguifhed by having a clufter or pencil of radicles under each leat, whereas the preceding has only one fingle radicle.

\section{TYPHA. Gen. 1\%. 1040.}

MASC. Amentum cylindricum. Cal.obfoletus, triphylliss. Cor. nuilla.

EEM. Amenium cylindricum infra mafculos. Cal. capillo villoro. Cor. o. Sem. 1 , infidens pappo capillari.

intifolis T. TYPHA foliis fubenfiformibus, fpica mafcula femineaq; approximatis. Sp.plo i 377 . (Ger. em. p. 46, Moris, bift, $\int .8 . t$. I $3 . f . I$, ordinis inferioris, iona.)

Great Car's-Tail, or Reed-mace. Anglis.

In the borders of ponds and lakes, as in ClofelurnI.ach, about eight miles above Dumfries, in the Black- 
Black-Loch, at the top of the parith of Tinarald, and in many other places and ftagnant waters. Dr. Burge's, 4, TII.

The falk is fix feet high : the leaves a yard long, h.ndly an inch wide, consex on one fide: the Anzentum, or cylindrical club, which terminates the lalk, is about fix inches long, of a dark brown or fufcous colour:

Cattle will fonetines eat the leaves, but sibieber thinks them noxious: the roots have foneimes been eaten in fallads, and the down of the Ainentum ufed to fluff mattrefes and cuthions: and linneus informs us, that the leaves are ufed by the coopers in Sweden to bind the hoops of their cafks. In Englend the coopers vife the falks of the Scirpus lacultris, or Bull-ru?h, to falten the joints of the timber $\mathrm{m}$ the heads of their caiks. One italk opened longitudinally, and laid between each juncture, anfwers the intention, as it prevents the oozing of the liquer through it.

\section{SPARGANIUM. Gin. 1\%. I04I.}

MASC. Amentum fubrotundum. Cal. 3-phyllus. Cor.o

FEM. Amentum fubrotundum. Cal. 3-phylus. Cor. o. Stigma 2-fidum. Drupa exfucca, 1-fperma.

crectun 1. SPARGANIUM foliis erectis triquetris. $s_{p}, p$ 1378 (Ger. cm. 45. f. 1. Pet. lert. i. 72 . f. 9 . Nioris. 
hift. .. 8. t. I 3.f. I, ordinis medii. Eं ejus varietas. Ger. em. 45, f. 2. Pet. berb t. 72.f. 10. Moris. bift. $\int .8 . t^{2}$ I $_{3}, f .3$. ordinis medii.)

Upright Bur.reed. Anglis.

On the banks of lochs, and ftagnant waters, not unfrequent. 4 . VII.

The ftalk is a yard high or more, ereet, firm, and branched: the lower leaves are triangular, the upper ones plain: the male Spberule terminate the branches, are much fmaller than the echinated female ones below them, and have fufcous $A n$ there.

The variety of mot authors, the figures of which are above cited, has a ftalk not above a cubit high, unbranched; the leaves, fo far as we have obferved, are nearly plain; and the. Antbere of the male fpharules of a pale yellow, or ftraw-colour'd. We are inclined to think it a diftinet fpecies. This is the kind which moft commonly occurs in scoiland.

ratans 2. SPARGANIUM foliis decumbentibus planis. Sp. p?. 1378 . (Pet.berb.t. 72, f. 11. Oed. Dan.t. 260) Floating Bur-reed. Anglis.

In the fmailer lochs of the highlands and Fiebrides frequent, as in the little lochs between Great and Little Breeze-bill, near Talifker, in Skye, and near Duntulm, in the fame inand. In the lochs going to Lcad-beg, from Little-Locb-Broom, in RofsBire. 
Aire. In the lochs of Breadalbane, Mr. Siuart. In Lock-Lomond, Dr. Parfons. It has been ohferved alfo in the lowlands by Dr. Burgess, as in the Caftle-Locb, near Lockmaben, in the mors adjoining to the lands of Myrefde, in the parifh of Holywood, near Dumfries, \&xc. 4. VIII. IX.

The ftalk is about two feet long, the leaves four, narrow, and almoft linear, being about $1-4$ th of an inch wide at the bafe, and I-8th in the middle, ending in a point. When held up between the eye and the light they appear reticulated, but this property is not peculiar to this fpecies. The female fphærules are commonly three, the two lowermoft fupported on peduncles, the uppermof fefile. The male ones are generally three, and all feffile: the leaves float upon the water like grafs; but when the plant Howers, the ftalk is raifed above the water three or four inches, the leaves ftill continuing to float.

\section{CAREX. Gen.pl. 1046.}

MASC. Amentum imbricatum. Cal, 1-phyllus. Cor. 0 .

FEM, Amentum imbricatum. Cal. I-phyllus. Cor: o. Nectarium inflatum, tridentatum. Stigm. 3 .

Sem. triquetrum, intra nectarium.

* Spica unica fimplici.

dicica $\mathrm{I}$.

CAREX Ipica fimplici dicica. Sp. pl. 1379. (Misbel. gen. t. 32. f. 1. Moris. bif. f. 8. t. 12. fig. 
fig. 22. (mas bon.) Oed. Dan. $t .369$, mas \& fem. opt.)

Dicecious Carex. Anglis.

In bogey places in the highlands and Hebrides, not unfrequent. 2!. VI.

The ftalk is round, friated, and about fix or feven iaches high. The leaves are narrow, almoft fetuceous, and about three or foug inches long: the rale and fermale fpikes grow on diftinct plants: the male is cylindrical, and about $3-4$ ths of an inch long; the female is at firtt oval, and about $1-4$ th of an inch long; but in the feeding ftate is produced, becomes cylindrical, and is often lenthened to half an inch. The ftyle has two figmato.

Whe have never yet been abie to difcover any permanent difference bewween the female of this fiant and the carex copitata of linmeus. The tigures quoted by that author for the C. capitata, viz. Moris. bif. J. S.t. 12.f. 36. and Mich. gen. t. 32. f. 1, 2. do exakty correfpond with the female variety of our plane, in its different tages of growth. Iinncus indeed affirms, that the C. capitata has fome male lowers at the fummit of the fpike; but fo far as we have yet obferv'd, this is by no means a conftant characteriftic. Thofe plants that have male flowers are rarely fern, and mized with them are more individuals that have none. The figure of Ded. Fl. Don. 1. 372. (fuppos'd by that author to be the C. cagitcra Lin) we know nothing of. It bids more fair 

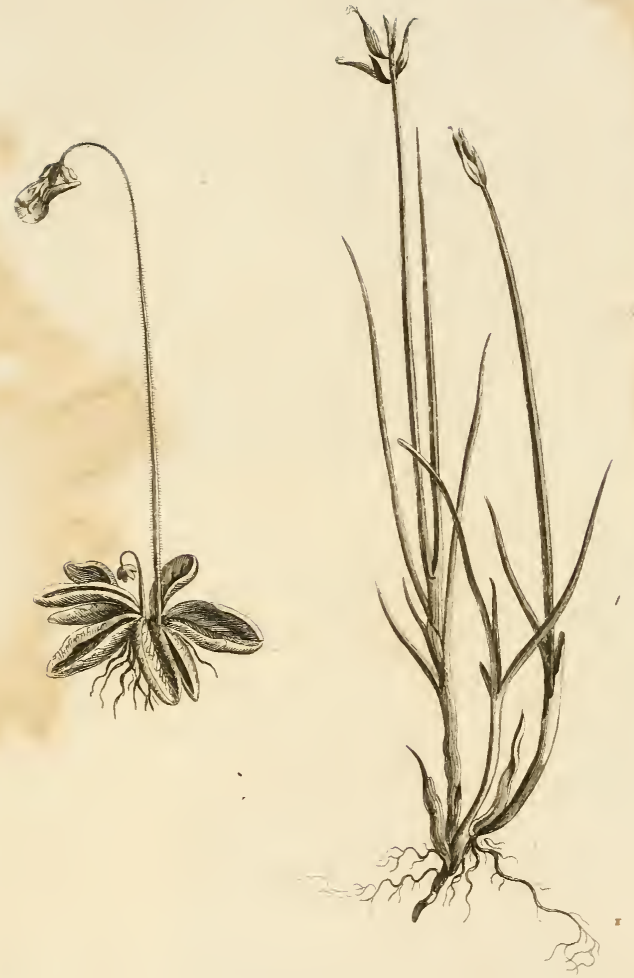

- Pineprecula rillese t: Ty

- Hosea Gimifitho del.

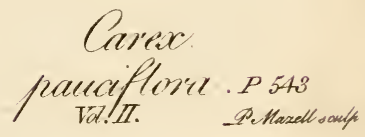

Carex

VI:II. Penarell soulf 

fair to be a Scirpus than a Corex, at leaft it has no male flowers nor radical leaves, which are defcribed as belonging to the C capitata Lin.

pulicaris 2. CAREX fpica fimplici androgyna; fofculis pluribus, mafculis terminalibus imbricatis, capfulis retroflexis. C. pulicaris Lin. Jp.pl. 1390. cbaracteribus emendatis. (Mich.gen. Ł.33.f. I. Pluk. phyt. t. 34. f. 10. Oed. Dani. t. I 66 ? non benè. Moris. bifi.f.8.t.12.f.21.opt)

Flea Carex. Anglis.

In bogs frequent. 4 . VI.

The flalk is round and ftriated, except being a little flat on one fide, and is about five or fix inches high: the leaves are very narrow, almoft fetaceous, and, when the plant is in fower, generally longer than the ftalk : the fpike is about 3-4ths of an inch long, fometimes an inch, terminated with a narrow cylinder of feveral male flowers which are diciduous: the females aro about fix or eight, placed underneath them in the fame foike, at firft erectly imbricated, but afterwards horizontal, and in the feeding ftate deflex'd, and of a bląkin colour. The ftyle is terminated with only two figmata.

paucifora 3 CAREX fpica fimplici androgyna; floribus femineis fubternis remotiufculis patentibus, mar culo unico terminali. (fig. noft.)

Few. Hower'd Carex. Anglis. 
We found this new fpecies of Carex in one place only, viz. In a boggy foil, about haif-way up the mountain of Goatficld, in the ine of Arran, near a place where peat is dug, in the afcent from Brodwick caftie. Mr. Banks has found the fame on the coaft of Labradore. 24. VI.

The ftalk is at a medium four inches high, obtcurely triangular, fmooth, ftriated, and furnifhed commonly with two fmooth, grafs like leaves, the uppermoft of which is longeft, but generally fhorter than the ftalk. The fpike is at firt clofe, and about 1 - Sth of an inch long, confinting of only one pale brown male flower at the top; and fometimes two; but more commonly three greenifh, long-acute female ones underneath. The male after flowering is deciduous, and the capfules become patent and nearly horizontal. 'The fyle has fometimes two, but commonly three figmata.

\section{* Spicis androgynis.}

incurva 4.

CAREX fpica conica, \&piculis congeftis androgynis feffilibus compolita, involucro nullo, culmo incurvo. (vid. fg. noft.)

Curved Carex. Anglis.

This new fpecies of Carex was communicated, by Dr. Hopie, the prefent ingenious profeffor of botany in Edinburgh. It was difcovered in deep loofe fea-fand, at the mouth of the water of Naver, and near Skelberry, in Dunro/ness, in sketlond. 24. VIT. 




